ALEXANDER HINCAPIÉ RAMÍREZ

\title{
INFLUÊNCIA DOS ÍONS BROMETO E CLORETO SOBRE A RESISTÊNCIA À CORROSÃO POR PITE DE DIFERENTES AÇOS INOXIDÁVEIS AUSTENITIICOS E FERRÍTICOS
}

Dissertação apresentada à Escola

Politécnica da Universidade de São Paulo para obtenção do titulo de Mestre em Engenharia 
ALEXANDER HINCAPIÉ RAMÍREZ

INFLUÊNCIA DOS ÍONS BROMETO E CLORETO SOBRE A RESISTÊNCIA À CORROSÃO POR PITE DE DIFERENTES AÇOS INOXIDÁVEIS AUSTENÍTICOS E FERRÍTICOS

Dissertação apresentada à Escola

Politécnica da Universidade de São Paulo

para obtenção do titulo de Mestre em

Engenharia

Área de Concentração:

Engenharia Metalúrgica e de Materiais

Orientadora:

Professora Doutora Neusa Alonso-Falleiros

São Paulo

2011 
Não quero estar livre de perigos, somente quero ter força para enfrentá-los. (anônimo) 


\section{AGRADECIMENTOS}

Agradeço a Deus, pela sua presença na minha vida, por me ajudar nas escolhas corretas que fiz, por me brindar com forças para seguir fortalecido neste caminho árduo e também pela iluminação que me tem dado no dia a dia. Dou infinitas graças a Deus pelo amor e carinho sincero com que me brinda, sem importar que tão longe me encontre dele.

Agradeço à professora Neusa Alonso Falleiros, pela oportunidade, pela orientação e pelo apoio moral que me deu durante o curto tempo do mestrado. Agradeço também pela amizade sincera que me brindou, pela confiança que depositou em mim, pelos conselhos que me deu e pelas experiências em nosso trabalho, as quais me ajudaram muito a enriquecer os poucos conhecimentos que aprendi durante este período de tempo.

Agradeço profundamente o apoio dos meus pais, do meu filho e da minha esposa, pois foram eles as pessoas que me ajudaram nesta etapa. Agradeço a meus pais especialmente pela educação e pela formação como pessoa e como profissional. Dou infinitas graças ao meu filho, pois foi sua presença que me deu forças para atingir os objetivos propostos na minha vida.

Tenho um agradecimento profundo por a minha esposa, sendo ela uma pessoa muito importante neste processo, pois com seus sábios conselhos e sua companhia desinteressada, me ajudou animadamente a suportar os problemas apresentados no dia a dia, e foi ela que, com o seu maior entusiasmo, colaborou com seu próprio tempo para me ajudar na redação deste trabalho.

Agradeço ao senhor Dr. Dairo Hernan Mesa, quem me ajudou de forma desinteressada na minha formação, sendo ele a pessoa que me deu conselhos valiosos para melhorar como pessoa e como profissional.

Agradeço a meus colegas Beatriz Amaral, Victor Bridi, Denis Massucatto, Flavia Paulucci Ciangas, Eduardo Junca, pois eles me brindaram com uma amizade muito sincera, foram eles que me permitiram sentir como em casa, como no meu país. Foram eles que me ajudaram com os conselhos sábios 
nos momentos difíceis, onde pensei não ter mais força para continuar neste processo.

Agradeço ao Antônio Lívio da Silva Nunes meu irmão de sangue, que com sua amizade fiel, conseguiu que eu me esquecesse dos problemas que se apresentaram no dia a dia da pesquisa, quem me ajudou com seus conhecimentos, quem me orientou, e que com sua felicidade me contagiou e permitiu que eu me sentisse no melhor país do mundo.

Agradeço a todo o pessoal que indiretamente me ajudou a construir este caminho difícil cheio de problemas e alegrias. 


\section{RESUMO}

A corrosão localizada em aços inoxidáveis pode se manifestar de várias formas, tais como, a corrosão por pite, em fresta e corrosão sob tensão. Estes tipos de corrosão ocorrem quando o metal é exposto em meios agressivos como o cloreto, entre outros.

O objetivo deste trabalho é estudar o comportamento dos aços inoxidáveis austeníticos e ferríticos em meios agressivos de cloreto, brometo e suas misturas. Para testar a resistência à corrosão por pite foi usado o método de polarização potenciodinâmica em eletrólitos de concentração iônica total de 0,6M. Os materiais estudados foram os aços inoxidáveis: 298 (aço inoxidável Cr-Mn, especificação da ArcelorMittal Inox Brasil) e os aços padronizados segundo a UNS: S30400, S31603, S43000 e S44400; todos, na condição tal como recebida da usina.

Os resultados mostraram que, em meio de $0,6 \mathrm{M}(\mathrm{NaCl}+\mathrm{NaBr})$, para concentrações de $0 \mathrm{M}$ a $0,45 \mathrm{M} \mathrm{NaCl}$, o desempenho quanto a resistência à corrosão por pite obedece a seguinte ordem decrescente: 444, 316L, 304, 298 e 430. Por sua vez, para a concentração de $0,6 \mathrm{M} \mathrm{NaCl}$, ou seja, ausência total de brometo, ocorre a alteração do desempenho dos aços inoxidáveis, colocando a seqüência da seguinte ordem: 316L, 444, 304, 298 e 430. Nota-se, portanto, que o melhor aço para ambientes contendo íon brometo seria o aço 444, já para aplicações em meio de cloreto puro, a melhor seleção é o aço 316L.

Foram encontrados sítios de nucleação nos diferentes aços testados nos eletrólitos de $0,6 \mathrm{M} \mathrm{NaCl}$ e $0,6 \mathrm{M} \mathrm{NaBr}$,sempre relacionados a inclusões: em alguns casos a nucleação ocorreu na interface matriz/inclusões insolúveis e, em outros, foram encontrados sinais de dissolução de inclusões, provavelmente de sulfeto.

As diferenças de resistência à corrosão por pite entre os diferentes aços, nos diferentes eletrólitos, foram discutidas em função das diferenças de composição química. 


\section{ABSTRACT}

Localized corrosion of stainless steels can be manifested in various forms, such as: pitting, crevice and stress corrosion. These types of corrosion occur due to exposition of metal in aggressive environments such as: chloride and bromide.

The mean goal of this work is to study the pitting corrosion resistance of both austenitic and ferritic stainless steels in aggressive environments containing chloride, bromide or their mixtures. The potentiodynamic polarization method was used to test the pitting corrosion resistance in media containing a total of ion concentration of 0,6M. The studied materials in this work were stainless steel: 298 (Cr-Mn steel, specification of ArcelorMittal Inox Brazil) and standardized steels according to the UNS: S30400, S31603, S43000 and S44400.

The results have shown that maintaining a constant concentration of $0.6 \mathrm{M}$ $(\mathrm{NaCl}+\mathrm{NaBr})$ into the electrolyte by varying the $\mathrm{NaCl}$ concentration between $0 \mathrm{M}$ and $0.45 \mathrm{M}$, the performance in terms of pitting corrosion obeys to the following decreasing order: 444, 316L, 304, 298 and finally 430. In turn, for a concentration of $0.6 \mathrm{M} \mathrm{NaCl}$, so without any bromide, there is a variation from the performance of stainless steels, putting the sequence as following: 316L, 444, 304, 298 and 430.

Nucleation sites were always found related to non-metallic inclusions in all tested stainless steels for the electrolytes of $0,6 \mathrm{M} \mathrm{NaCl}$ or $0,6 \mathrm{M} \mathrm{NaBr}$. Sometimes, pits nucleation occurred at the matrix/inclusion interface, but others times, pits nucleated in water soluble inclusions.

Difference of the pitting corrosion resistance between tested steel in the different electrolytes have been discussed as a function of the chemical composition. 


\section{LISTA DE FIGURAS}

Figura 1 - Evolução da produção mundial de aço inoxidável em milhões de toneladas.

Figura 2 - Evolução da produção Brasileira de aço inoxidável em miles de toneladas. 7

Figura 3 - Microestrutura de aço inoxidável ferrítico 430. A microestrutura é constituída por grãos recristalizados de ferrita com carbonetos de cromo. Ataque químico Vilella. 9

Figura 4 - Aço inoxidável austenítico 304 forjado e solubilizado. Cortesia de Villares Metals S.A. 10

Figura 5 - Efeito da \%Cr e \%Mn sobre a solubilidade do nitrogênio(26)......... 13

Figura 6 - Estabilidade da fase austenita em $1075^{\circ} \mathrm{C}$ 14

Figura 7 - Esquema da curva de polarização potenciodinâmica mostrando os potenciais críticos. 16

Figura 8 - Representação esquemática do mecanismo de adsorção. 20

Figura 9 - Representação esquemática do mecanismo de penetração.. 21

Figura 10 - Representação esquemática do mecanismo de quebra do filme .. 22 Figura 11 - Mecanismo autocatalítico de crescimento de pite em aços inoxidáveis.

Figura 12 - Influência da forma das inclusões de MnS na nucleação de pites estáveis e instáveis, na presença e ausência de tensões mecânicas. 25

Figura 13 - Diagrama Potencial-pH para um sistema $\mathrm{MnS}-\mathrm{H}_{2} \mathrm{O}-\mathrm{Cl}^{-}$calculado para $0,1 \mathrm{M}$ de íons $\mathrm{SO}_{4}^{-2}, \mathrm{Cl}^{-}$e $\mathrm{Mn}^{+2}$. 26

Figura 14 - Tabela de classificação padrão para pites 28

Figura 15 - Efeito de alguns elementos químicos sobre a resistência à corrosão por pite em solução de cloreto. 29

Figura 16 - Efeito do teor de cromo sobre o potencial de pite em liga $\mathrm{Fe}-\mathrm{Cr}$ em solução desaerada de $0,1 \mathrm{~N} \mathrm{NaCl}$. 30

Figura 17 - Efeito do teor de molibdênio sobre o potencial de pite de ligas Fe$15 \mathrm{Cr}-13 \mathrm{Ni}$ em solução desaerada $0,1 \mathrm{~N} \mathrm{NaCl}$ em $25^{\circ} \mathrm{C}$. 
Figura 18 - Exames em MEV de um pite formado no aço 316 L com alto teor de molibdênio $(2,74 \% \mathrm{Mo}$ e $0,98 \% \mathrm{Mn})$ após polarização potenciodinâmica em solução aquosa de $3,5 \% \mathrm{NaCl}$ até o potencial próximo ao potencial de pite .... 33 Figura 19 - Diagrama de Pourbaix para o sistema de $\mathrm{Mo}-\mathrm{H}_{2} \mathrm{O}$ a $25^{\circ} \mathrm{C}$. 34

Figura 20 - Primeiro estágio do mecanismo do efeito combinado do Mn e Mo sobre a corrosão por pite dos aços inoxidáveis austeníticos em meios contendo cloreto. 35

Figura 21. Segundo estágio do mecanismo do efeito combinado do $\mathrm{Mn}$ e Mo sobre a corrosão de pite dos aços inoxidáveis austeníticos em meios contendo cloreto. 36

Figura 22 - Terceiro estágio do mecanismo do efeito combinado do Mn e Mo sobre a corrosão de pite dos aços inoxidáveis austeníticos em meios contendo cloreto. 36

Figura 23 - Corpo-de-prova (embutido em baquelita) utilizado para a caracterização microestrutural.

Figura 24 - Esquema dos corpos-de-prova para os ensaios de polarização potenciodinâmica.

Figura 25 - Distribuição das inclusões no aço inoxidável austenítico 298. Polimento com pasta de diamante $1 \mu \mathrm{m}$. Imagem de elétrons retroespalhados (BSE) com um aumento de 1000x.

Figura 26 - Imagem de elétrons retroespalhados da superfície de aço 298 polida até diamante $1 \mu \mathrm{m}$. Observam-se inclusões com formatos alongados (2) e arredondados (1); o ponto (3) representa a matriz. Aumento de 2500x

Figura 27 - Espectros das analises por EDS. (a) ponto 1: inclusão de Al-Cr-Mn$\mathrm{O}$, (b) ponto 2: inclusão de Al-Si-Mn-Ca-O e (c) ponto 3: matriz. 46

Figura 28 - Imagem de elétrons retroespalhados da superfície de aço 298 polida até diamante $1 \mu \mathrm{m}$. Observa-se uma inclusão com formato alongado. Análise por EDS (a) inclusão (b) matriz. Aumento de 6500x. 47 Figura 29 - Espectros das analises por EDS. (a) inclusão predominantemente de $\mathrm{Si}$-O; os teores de Fe-Cr-Ni-Mn são provenientes da matriz, dado o pequeno tamanho da região analisada e (b) matriz.

Figura 30 - Imagem de elétrons retroespalhados da superfície de aço 298 polida até diamante $1 \mu \mathrm{m}$. Observa-se uma inclusão com formato globular. Análise por EDS (a) inclusão (b) matriz. Aumento de 8000x 
Figura 31 - Espectros das analises por EDS. (a) inclusão predominantemente de MnS e Si-O; os teores de Fe-Cr-Ni-Mn são provenientes da matriz, dado o pequeno tamanho da região analisada e (b) matriz. 49

Figura 32 - Imagem de elétrons retroespalhados da superfície de aço 298 polida até diamante $1 \mu \mathrm{m}$. Nota-se uma inclusão com formato alongado. Análise por EDS (a) inclusão . Aumento de 10000x. 50

Figura 33 - Espectros das analises por EDS na inclusão. Nota-se teores predominantes de S e Mn, o que indica a existencia de MnS. Cabe salientar que os teores de Fe-Cr-Ni são provenientes da matriz. 50

Figura 34 - Microestrutura do aço inoxidável austenítico 298. Polimento e ataque eletrolítico com reagente ácido perclórico 5\%. Nota-se a matriz constituída de grãos recristalizados de austenita e a presença de maclas. Aumento $1000 \mathrm{x}$

Figura 35 - Distribuição das inclusões no aço inoxidável austenítico 304. Polimento superficial até $1 \mu \mathrm{m}$. Imagem de elétrons retroespalhados com um aumento de 1000x. 52

Figura 36 - Aspecto de inclusão encontrada no aço 304 após polimento até $1 \mu \mathrm{m}$. Nota-se a presença de inclusão alongada e outras na forma globular, bem menores. Imagem de elétrons retroespalhados. Aumento de 2500x. 52 Figura 37 - Espectros das analises por EDS na inclusão não metálica (ponto 1) e na matriz (ponto 2). Nota-se que a inclusão é constituída de óxido de alumínio e na matriz são encontrados os elementos: Fe-Cr-Ni-Mn. 53

Figura 38 - Aspecto das inclusões encontradas no aço 304 após polimento até $1 \mu \mathrm{m}$. Nota-se a presença de inclusões alongadas e outras sem um formato definido. Imagem de elétrons retroespalhados. Aumento de 6500x. 54

Figura 39 - Espectros das analises por EDS na inclusão não metálica presente na superfície do aço 304. (a) ponto 1: inclusão e (b) ponto 2: matriz. 55 Figura 40 - Aspecto da inclusão encontrada no aço 304 após polimento até $1 \mu \mathrm{m}$. Imagem de elétrons retroespalhados. Aumento de 12000x. 55 Figura 41 - Espectros das analises por EDS na inclusão não metálica presente na superfície do aço 304. (a) ponto 1: inclusão e (b) ponto 2: matriz. 56 Figura 42 - Imagem de elétrons retroespalhados da superfície de aço 304 polida até diamante $1 \mu \mathrm{m}$. Nota-se uma inclusão com formato alongado. Análise por EDS (a) inclusão . Aumento de 10000x 
Figura 43 - Espectros das analises por EDS na inclusão. Nota-se teores predominantes de S e Mn, o que indica a existência de MnS. Cabe salientar que os teores de Fe-Cr-Ni são provenientes da matriz. 57

Figura 44 - Microestrutura do aço inoxidável austenítico 304. Nota-se a matriz constituída de grãos recristalizados de austenita e a presença de maclas de recozimento. Imagem de elétrons secundários. Polimento eletrolítico em ácido perclórico $5 \%$ e ataque eletrolítico feito com ácido oxálico $10 \%$. Aumento $1000 x$ 58

Figura 45 - Distribuição das inclusões no aço inoxidável austenítico 316L. Polimento superficial até $1 \mu \mathrm{m}$. Imagem de elétrons retroespalhados com um aumento de 1000x 59

Figura 46 - Aspecto da inclusão encontrada no aço $316 \mathrm{~L}$ após polimento até $1 \mu \mathrm{m}$. Imagem de elétrons retroespalhados. Aumento de 6500x. Nota-se pequenas inclusões distribuídas aleatoriamente ao redor da inclusão maior... 59 Figura 47 - Espectro de analises por EDS na inclusão não metálica presente na superfície do aço $316 \mathrm{~L}$ 60

Figura 48 - Aspecto da inclusão encontrada no aço 316L após polimento até $1 \mu \mathrm{m}$. Imagem de elétrons retroespalhados. Aumento de 6500x. Nota-se uma diferença do cor na inclusão, o que indica uma diferença significativa na composição química. 60

Figura 49 - Espectro de analises por EDS. (a) Inclusão não metálica (1) e (b) matriz (aço 316L).

Figura 50 - Aspecto da inclusão (formato alongado) encontrada no aço $316 \mathrm{~L}$ após polimento até $1 \mu \mathrm{m}$. Imagem de elétrons retroespalhados. Aumento de $8000 x$ 62

Figura 51 - Espectro de analises por EDS realizada na inclusão. Cabe ressaltar que os picos de $\mathrm{Cr}$, Fe e Ni correspondem aos teores da matriz do aço 316L.63 Figura 52 - Microestrutura do aço inoxidável austenítico 316L. Aumento: 1000x. Nota-se a matriz constituída de grãos recristalizados de austenita e a presença de maclas de recozimento. Imagem de elétrons secundários. Ataque eletrolítico com ácido oxálico 10\%.

Figura 53 - Distribuição das inclusões no aço inoxidável ferrítico 430. Polimento superficial até $1 \mu \mathrm{m}$. Imagem de elétrons retroespalhados com um aumento de $1000 x$. 64 
Figura 54 - Imagem de elétrons retroespalhados. Aspecto de duas inclusões encontradas na superfície do aço $316 \mathrm{~L}$ após polimento até $1 \mu \mathrm{m}$. (a) formato alongado: aumento de 2500 e (b) formato globular: aumento de 12000x........ 65 Figura 55 - Espectro de analises por EDS realizada nas inclusões. Cabe ressaltar que os picos de $\mathrm{Cr}$ e Fe (Figura 55(b)) correspondem aos teores da matriz do aço $316 \mathrm{~L}$ 66

Figura 56 - Imagem de elétrons retroespalhados. Aspecto de duas inclusões (formato globular) encontradas na superfície do aço $316 \mathrm{~L}$ após polimento até $1 \mu \mathrm{m}$. Aumento de 8000x. 67

Figura 57 - Espectro de analises por EDS realizada nas inclusões (ponto 1 e ponto 2). Cabe ressaltar que os picos de Fe (Figura 57(a) e (b)) correspondem à matriz do aço. 68

Figura 58 - Imagem de elétrons retroespalhados da superfície do aço 430 , sem ataque, apresentando 0 aspecto das inclusões encontradas. $O$ polimento foi realizado até $1 \mu \mathrm{m}$. Aumento de $15000 \mathrm{x}$.

Figura 59 - Análise por EDS realizada para determinar a composição química da inclusão: (a) ponto 1; do carboneto de cromo: ponto (2) e da matriz ponto (3) para comparação.

Figura 60 - Imagem de elétrons retroespalhados da superfície do aço 430, polido até $1 \mu \mathrm{m}$ sem ataque. Inclusões não metálicas presentes no material. Aumento de 3500x. 71

Figura 61 - Composição química obtida por análise por EDS: (a) ponto 1 inclusão e (b) ponto 2 - matriz. 72

Figura 62 - Microestrutura do aço inoxidável ferrítico 430. Nota-se a matriz constituída de grãos recristalizados de ferrita e a presença de cavidades, indicando que aí havia precipitados de carbonetos de cromo, intragranulares e intergranulares. Imagem de elétrons retroespalhados. Ataque eletrolítico com ácido oxálico 10\%. Aumento 1000x. 73

Figura 63 - Distribuição das inclusões no aço inoxidável ferrítico 444. Polimento superficial até $1 \mu \mathrm{m}$. Imagem de elétrons retroespalhados com um aumento de 1000x.

Figura 64 - Imagem de elétrons retroespalhados da superfície do aço 444, polido até $1 \mu \mathrm{m}$ sem ataque. Inclusões não metálicas presentes no material. (a) 
inclusão de cor preta alongada: ponto 1 e (b) inclusão cinza: ponto 2. Aumento de $3500 x$

Figura 65 - Análise por EDS realizada para determinar a composição química das inclusões: (a) ponto 1:inclusão preta, (b) ponto 2: inclusão cinza e (c) matriz para efeito de comparação.

Figura 66 - Imagem de elétrons retroespalhados da superfície do aço 444, polido até $1 \mu \mathrm{m}$ sem ataque. Nota-se cores distintas na inclusão, o que significa uma diferença de composição química. (a) Ponto 1: rica em titânio, (b) ponto 2: óxidos de Al (cor preta) e (c) ponto 3: nitretos de titânio. Aumento de 12000x.

Figura 67 - Análise por EDS realizada para determinar a composição química da inclusão. (a) Ponto 1: região rica em titânio, (b) ponto 2: óxido de $\mathrm{Al}$ (cor preta) e (c) ponto 3: nitreto de titânio.

Figura 68 - Imagem de elétrons retroespalhados da superfície do aço 444, polido até $1 \mu \mathrm{m}$ sem ataque. Nota-se cores distintas (cor cinza na borda) na inclusão, o que significa uma diferença de composição química. Aumento de 25000x. 79

Figura 69 - Análise por EDS realizada para determinar a composição química da inclusão. Cabe ressaltar que não é possível determinar a composição química das duas regiões devido ao pequeno tamanho da inclusão. 79

Figura 70 - Microestrutura do aço inoxidável ferrítico 444. Aumento de 1000x. Nota-se a matriz constituída de grãos recristalizados de ferrita e a presença de algumas cavidades, provenientes da dissolução de inclusões. Imagem de elétrons retroespalhados. Ataque eletrolítico com ácido oxálico $10 \%$ 80

Figura 71 - Curvas de polarização do aço inoxidável austenítico 298. (a) 0,6M $\mathrm{NaCl}$ e (b) 0,45M NaCl+0,15M NaBr. 84

Figura 72 - Curvas de polarização do aço inoxidável austenítico 298. (a) 0,3M $\mathrm{NaCl}+0,3 \mathrm{M} \mathrm{NaBr}$ e (b) $0,6 \mathrm{M} \mathrm{NaCl}$. 85

Figura 73 - Sobreposição das curvas de polarização do aço inoxidável austenítico 298 em meios contendo cloreto, brometo e suas misturas. 85 Figura 74 - Curvas de polarização do aço inoxidável austenítico 304. (a) 0,6M $\mathrm{NaCl}$ e (b) $0,45 \mathrm{M} \mathrm{NaCl}+0,15 \mathrm{M} \mathrm{NaBr}$.

Figura 75 - Curvas de polarização do aço inoxidável austenítico 304. (a) 0,3M $\mathrm{NaCl}+0,3 \mathrm{M} \mathrm{NaBr}$. e (b) 0,6M NaBr. 88 
Figura 76 - Sobreposição das curvas de polarização do aço inoxidável austenítico $304 \mathrm{em}$ meios contendo cloreto, brometo e suas misturas. 89

Figura 77 - Curvas de polarização do aço inoxidável austenítico 316L. (a) 0,6M $\mathrm{NaCl}$; (b) $0,45 \mathrm{M} \mathrm{NaCl}+0,15 \mathrm{M} \mathrm{NaBr}$. 91

Figura 78 - Curvas de polarização do aço inoxidável austenítico 316L. (a) 0,3M $\mathrm{NaCl}+0,3 \mathrm{M} \mathrm{NaBr}$ e (b) $0,6 \mathrm{M} \mathrm{NaBr}$. 92

Figura 79 - Sobreposição das curvas de polarização do aço inoxidável austenítico 316L em meios cloreto, brometo e suas misturas. .93

Figura 80 - Curvas de polarização do aço inoxidável ferrítico 430 . (a) $0,6 \mathrm{M}$ $\mathrm{NaCl}$ e (b) $0,45 \mathrm{M} \mathrm{NaCl}+0,15 \mathrm{M} \mathrm{NaBr}$. 94

Figura 81 - Curvas de polarização do aço inoxidável ferrítico 430. (a) $0,3 \mathrm{M}$ $\mathrm{NaCl}+0,3 \mathrm{M} \mathrm{NaBr}$ e (b) $0,6 \mathrm{M} \mathrm{NaBr}$ 95

Figura 82 - Sobreposição das curvas de polarização do aço inoxidável ferrítico $430 \mathrm{em}$ meios contendo cloreto, brometo e suas misturas. 96

Figura 83 - Curvas de polarização potenciodinâmica do aço 444 . (a) $0,6 \mathrm{M} \mathrm{NaCl}$ e (b) $0,45 \mathrm{M} \mathrm{NaCl}+0,15 \mathrm{M} \mathrm{NaBr}$. 98

Figura 84 - Curvas de polarização do aço inoxidável ferrítico 444. (a) 0,3M $\mathrm{NaCl}+0,3 \mathrm{M} \mathrm{NaBr}$ e (b) $0,6 \mathrm{M} \mathrm{NaBr}$. 99

Figura 85 - Sobreposição das curvas de polarização do aço inoxidável ferrítico 444 em meios contendo cloreto, brometo e suas misturas. 99

Figura 86 - Pite nucleado em inclusão (ponto 1). Aço 298 em 0,6M NaCl. Imagem de elétrons secundários e aumento de 15000x 101

Figura 87 - Espectros das análises por EDS. (a) Inclusão: ponto 1 e (b) matriz: para efeito de comparação. 102

Figura 88 - Representação esquemática do mecanismo da dissolução da interface matriz/inclusão de óxido(68). A microfresta é o ângulo formado entre os pontos 3,1 e 2 . 103

Figura 89 - Exemplo de precipitação de sal de $\mathrm{Cl}^{-}(\mathrm{NaCl})$ na interface de uma inclusão de óxido alumínio. (a) Imagem de elétrons secundários. (b) Espectro da análise por EDS da inclusão (ponto 1) e (c) espectro da análise por EDS do sal precipitado. 104

Figura 90 - Pite nucleado na interface matriz/inclusão (ponto 1). Aço 298 em $0,6 \mathrm{M} \mathrm{NaBr}$. Imagem de elétrons secundários e aumento de 12000x. 105 
Figura 91 - Espectros da análise por EDS. (a) Inclusão: ponto 1 e (b) matriz: para efeito de comparação. 106

Figura 92 - Pites contendo um residual de inclusão (ponto 1 e ponto 2). Aço 304 em 0,6M NaCl. Imagem de elétrons secundários e aumento de 15000x. 107 Figura 93 - Espectro da análise por EDS no resíduo encontrado no fundo dos pites (inclusão): notam-se elevados teores de $\mathrm{Ba}$ e $\mathrm{S}$, e em menor porcentagem Si. Cabe ressaltar que os teores de $\mathrm{Cr}$, Fe e Ni correspondem à matriz. Este espectro foi realizado para o ponto 1 da Figura 92; a análise para o ponto 2 apresentou o mesmo resultado. 108

Figura 94 - Pite nucleado em interface de inclusão (ponto 1). Aço 304 em 0,6M $\mathrm{NaBr}$. Imagem de elétrons secundários e aumento de 10000x 109

Figura 95 - Espectros da análise por EDS. (a) Inclusão (ponto 1): nota-se a presença de Al. Cabe ressaltar que os teores de $\mathrm{Cr}$, Fe e Ni correspondem à matriz, e (b) matriz: para efeito de comparação.

Figura 96 - Pite contendo um residual de inclusão (ponto 1). Aço $316 \mathrm{~L}$ em $0,6 \mathrm{M} \mathrm{NaCl}$. Imagem de elétrons secundários e aumento de 15000x 111

Figura 97 - Espectros da análise por EDS na inclusão (ponto 1 da Figura 11): nota-se elevado teor de $\mathrm{S}$ e $\mathrm{Ba}$, além de Si. Cabe ressaltar que os teores de $\mathrm{Cr}$, Fe e Ni correspondem à matriz. 111

Figura 98 - Pites contendo um residual de inclusão (ponto 1 e ponto 2). Aço $316 \mathrm{I}$ em 0,6M NaBr. Imagem de elétrons secundários e aumento (a) 6500x e (b) $25000 \mathrm{x}$ 112

Figura 99 - Espectro da análise por EDS na inclusão do ponto 1 da Figura 13: nota-se elevado teor de $\mathrm{S}$ e $\mathrm{Ba}$ e em menor quantidade $\mathrm{Si}$. Cabe ressaltar que os teores de $\mathrm{Cr}$, Fe e $\mathrm{Ni}$ correspondem à matriz. $\mathrm{A}$ análise para o ponto 2 da Figura 13 apresentou o mesmo resultado. 113

Figura 100 - Pite contendo residual de inclusão (ponto 1). Aço 430 em 0,6M $\mathrm{NaCl}$. Imagem de elétrons secundários e aumento de 15000x 114 Figura 101 - Espectro da análise por EDS na inclusão (ponto 1 da Figura 15): nota-se elevado teor de S, Ba e Si. Já no caso dos teores de $\mathrm{Cr}$, Fe e Ni, eles correspondem à matriz.

Figura 102 - Em (a), tem-se a nucleação de pite na interface da inclusão, ainda em estágio inicial, assemelhando-se a uma microfresta (região 2); em (b) tem-se um pite, em estágio avançado de crescimento, provavelmente nucleado 
na interface da inclusão (ponto 3). Aço 430 em 0,6M NaBr. Imagem de elétrons secundários e aumento de 8000x. 115

Figura 103 - Espectro da análise por EDS na inclusão (ponto 1 da Figura 17): nota-se elevado teor de Si e Mg, além Al. Já no caso dos teores de $\mathrm{Cr}$, Fe e Ni, eles correspondem à matriz. A análise para a inclusão do ponto 3 da Figura 17 (b) apresentou o mesmo resultado. 116

Figura 104 - Pite nucleado na interface matriz/inclusão (ponto 1). Aço $444 \mathrm{em}$ $0,6 \mathrm{M} \mathrm{NaCl}$. Imagem de elétrons secundários e aumento de 20000x 117

Figura 105 - Espectro da análise por EDS na inclusão (ponto 1 da Figura 19): nota-se elevado teor de Al e em menor teor, Si. Já no caso dos teores de $\mathrm{Cr}$, $\mathrm{Fe}$ e $\mathrm{Ni}$, eles correspondem à matriz. 117

Figura 106 - Pite nucleado na interface matriz/inclusão (ponto 1). Aço 444 em $0,6 \mathrm{M} \mathrm{NaCl}$. Imagem de elétrons secundários e aumento de 15000x. Superfície polida até $3 \mu \mathrm{m}$.

Figura 107 - Espectro da análise por EDS na inclusão (ponto 1 da Figura 21): nota-se elevado teor de Al e em menor teor, Si. Já no caso dos teores de $\mathrm{Cr}$, $\mathrm{Fe}$ e $\mathrm{Ni}$, eles correspondem à matriz. 118

Figura 108 - Pite nucleado na interface matriz/inclusão (ponto 1). Aço 444 em $0,6 \mathrm{M} \mathrm{NaBr}$. Imagem de elétrons secundários. Superfície polida até $3 \mu \mathrm{m}$. (a)

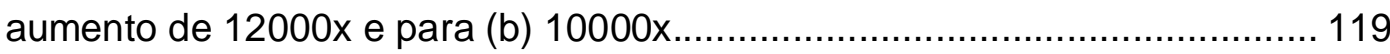

Figura 109 - Espectro da análise por EDS na inclusão (ponto 1 da Figura 109 (a)): nota-se a presença de Si. Já no caso dos teores de $\mathrm{Cr}$, Fe e Ni, eles correspondem à matriz. (a) e (b) tem o mesmo resultado, ou seja, é uma inclusão de silício nos dois casos. 120

Figura 110 - Curva de polarização potenciodinâmica do aço $316 \mathrm{~L}$ no eletrólito $0,3 \mathrm{M} \mathrm{NaCl}+0,3 \mathrm{M} \mathrm{NaBr}$. Nota-se um aumento drástica da densidade de corrente em potenciais próximos de $15 \mathrm{mV}$. 122

Figura 111 - Imagem de elétrons secundários para o aço 298. Distribuição dos pites na superfície do aço 298.(a) $0,6 \mathrm{M} \mathrm{NaCl}$, (b) $0,45 \mathrm{M} \mathrm{NaCl}+0,15 \mathrm{M} \mathrm{NaBr}$, (c) $0,3 \mathrm{M} \mathrm{NaCl}+0,3 \mathrm{M} \mathrm{NaBr}$ e (d) 0,6M NaBr. Lixa \#600. Aumento 50x. 125

Figura 112 - Imagens de elétrons secundários dos pites nucleados na superfície do aço 298 durante o ensaio de corrosão. (a) $0,6 \mathrm{M} \mathrm{NaCl}$, (b) $0,45 \mathrm{M}$ $\mathrm{NaCl}+0,15 \mathrm{M} \mathrm{NaBr}$, (c) $0,3 \mathrm{M} \mathrm{NaCl}+0,3 \mathrm{M} \mathrm{NaBr}$ e (d) 0,6M NaBr. Lixa \#600. Aumento 800x. 126 
Figura 113 - Imagem de elétrons secundários para o aço 304. Distribuição dos pites na superfície. (a) $0,6 \mathrm{M} \mathrm{NaCl}$, (b) $0,45 \mathrm{M} \mathrm{NaCl}+0,15 \mathrm{M} \mathrm{NaBr}$, (c) $0,3 \mathrm{M}$ $\mathrm{NaCl}+0,3 \mathrm{M} \mathrm{NaBr}$ e (d) 0,6M NaBr. Lixa \#600. Aumento 50x. 127

Figura 114 - Imagens de elétrons secundários dos pites nucleados na superfície do aço 304 durante o ensaio de corrosão. .(a) $0,6 \mathrm{M} \mathrm{NaCl}$, (b) $0,45 \mathrm{M}$ $\mathrm{NaCl}+0,15 \mathrm{M} \mathrm{NaBr}$, (c) 0,3M NaCl+0,3M NaBr e (d) 0,6M NaBr. Lixa \#600. Aumento 800x para (a), (b) e (c), e 1500x para (d). 128

Figura 115 - Imagem de elétrons secundários para o aço $316 \mathrm{~L}$. (a) $0,6 \mathrm{M} \mathrm{NaCl}$, (b) $0,45 \mathrm{M} \mathrm{NaCl}+0,15 \mathrm{M} \mathrm{NaBr}$, (c) $0,3 \mathrm{M} \mathrm{NaCl}+0,3 \mathrm{M} \mathrm{NaBr}$ e (d) 0,6M NaBr. Lixa \#600. Aumento 50x. 129

Figura 116 - Imagens de elétrons secundários dos pites nucleados na superfície do aço $316 \mathrm{~L}$ durante o ensaio de corrosão. (a) $0,6 \mathrm{M} \mathrm{NaCl}$, (b) $0,45 \mathrm{M}$ $\mathrm{NaCl}+0,15 \mathrm{M} \mathrm{NaBr}$, (c) $0,3 \mathrm{M} \mathrm{NaCl}+0,3 \mathrm{M} \mathrm{NaBr}$ e (d) 0,6M NaBr. Lixa \#600. Aumento 800x. 130

Figura 117 - Imagem de elétrons secundários para o aço 430. (a) $0,6 \mathrm{M} \mathrm{NaCl}$, (b) $0,45 \mathrm{M} \mathrm{NaCl}+0,15 \mathrm{M} \mathrm{NaBr}$, (c) $0,3 \mathrm{M} \mathrm{NaCl}+0,3 \mathrm{M} \mathrm{NaBr}$ e (d) 0,6M NaBr. Aumento 50x. Lixa \#600. 131

Figura 118 - Imagens de elétrons secundários dos pites nucleados na superfície do aço 430 durante o ensaio de corrosão. (a) $0,6 \mathrm{M} \mathrm{NaCl}$, (b) $0,45 \mathrm{M}$ $\mathrm{NaCl}+0,15 \mathrm{M} \mathrm{NaBr}$, (c) $0,3 \mathrm{M} \mathrm{NaCl}+0,3 \mathrm{M} \mathrm{NaBr}$ e (d) $0,6 \mathrm{M} \mathrm{NaBr}$. Lixa \#600. Aumento 800x para (a), (b), de 1000x para (c) e 2500x para (d)................. 132 Figura 119 - Imagem de elétrons secundários. Nota-se a presença de carbonetos de cromo globulares no interior do pite. Aumento 8000x. 132 Figura 120 - Espectro da análise por EDS realizada no ponto 1 (resíduo com formato globular). Nota-se elevado teor de $\mathrm{Cr}$. 133

Figura 121 - Imagem de elétrons secundários para o aço 444. Distribuição dos pites na superfície do aço 444 .(a) $0,6 \mathrm{M} \mathrm{NaCl}$, (b) $0,45 \mathrm{M} \mathrm{NaCl}+0,15 \mathrm{M} \mathrm{NaBr}$, (c) $0,3 \mathrm{M} \mathrm{NaCl}+0,3 \mathrm{M} \mathrm{NaBr}$ e (d) 0,6M NaBr. Lixa \#600. Aumento 50x. 134 Figura 122 - Imagens de elétrons secundários dos pites nucleados na superfície do aço 444 durante o ensaio de corrosão. (a) $0,6 \mathrm{M} \mathrm{NaCl}$, (b) $0,45 \mathrm{M}$ $\mathrm{NaCl}+0,15 \mathrm{M} \mathrm{NaBr}$, (c) 0,3M NaCl+0,3M NaBr e (d) 0,6M NaBr. Lixa \#600. Aumento $800 x$ para (a) e (b), de 1000x para (c) e 1200x para (d). 135 Figura 123 - Influência do teor dos íons agressivos de cloreto e brometo no potencial de pite dos aços $(298,304,316 \mathrm{~L}, 430$ e 444). O eixo horizontal 
inferior é "Concentração de cloreto"; o eixo horizontal superior é "Concentração de brometo". O eixo vertical é: "Potencial de pite $(\mathrm{mV}, \mathrm{Ag} / \mathrm{AgCl})$ ". A concentração total de íons agressivos é de 0,6M em todos os casos............ 138 


\section{LISTA DE TABELAS}

Tabela 1 - Composição química nominal dos aços inoxidáveis S20100 e S20200

Tabela 2 - Equivalente de resistência à corrosão por pite para aços inoxidáveis ferríticos, austeníticos e duplex (1).

Tabela 3 - Composições químicas (\% em massa) e espessuras dos aços inoxidáveis utilizados no presente trabalho. 38

Tabela 4 - Espessura das chapas de aço utilizadas para a caracterização metalográfica a para os ensaios de corrosão. 39

Tabela 5 - Composição química dos eletrólitos utilizados nos ensaios de polarização potenciodinâmica. 42

Tabela 6 - Resumo das principais inclusões encontradas nos aços do presente estudo. 81

Tabela 7 - Valores de pH para os eletrólitos do presente trabalho. 90

Tabela 8 - Resumo das inclusões que mostraram maior susceptibilidade à corrosão por pite. 120 


\section{SUMÁRIO}

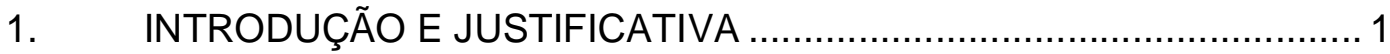

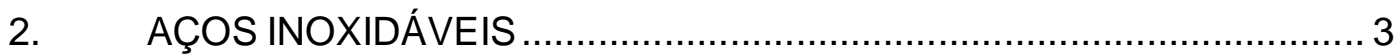

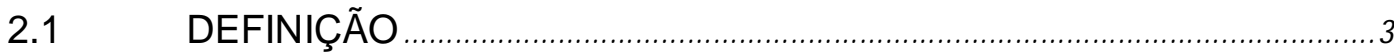

2.2 GENERALIDADES DA RESISTÊNCIA À CORROSÃO DOS AÇOS INOXIDÁVEIS 3

2.3 INFLUÊNCIA METALÚRGICA DOS ELEMENTOS DE LIGA NOS AÇOS INOXIDÁVEIS

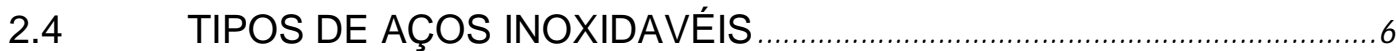

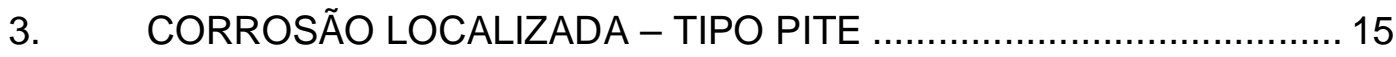

3.1 PELÍCULA PASSIVA

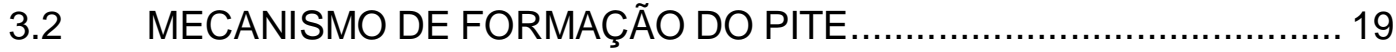

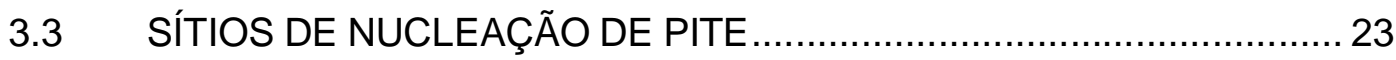

3.4 MEDIDA DA SUSCEPTIBILIDADE À CORROSÃO POR PITE ............ 27

3.5 EFEITOS DOS ELEMENTOS DE LIGA ….................................. 28

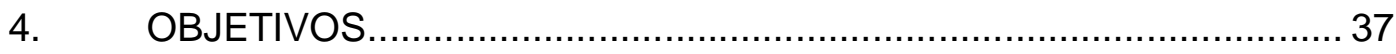

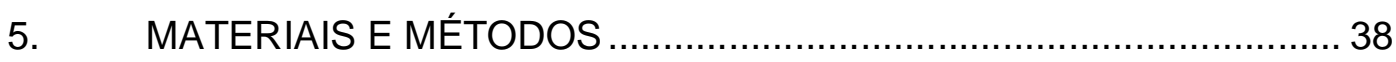

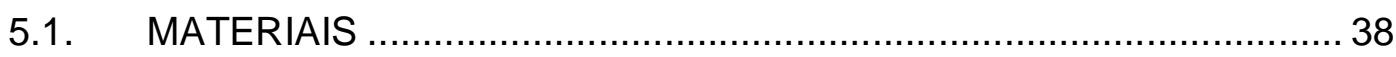

5.2 PREPARAÇÃO DOS CORPOS-DE-PROVA .................................. 39

5.2.1 CARACTERIZAÇÃO METALOGRAFICA …........................................... 41

5.2.2 ENSAIO DE CORROSÃO ........................................................................... 41

5.2.2.1 PREPARAÇÃO DOS ELETRÓLITOS ….................................................. 41

5.2.2.2 ENSAIOS DE POLARIZAÇÃO POTENCIODINÂMICA ...........................4 42

5.3 MORFOLOGIA DE CORROSÃO E SítiOS DE NUCLEAÇÃO DE

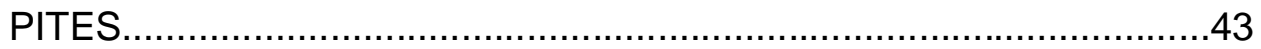

6. RESULTADOS EXPERIMENTAIS E DISCUSSÃO ..........................44

6.1 CARACTERIZAÇÃO MICROESTRUTURAL ................................. 44 
6.1.1 AÇO 298

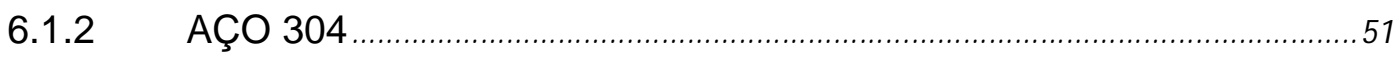

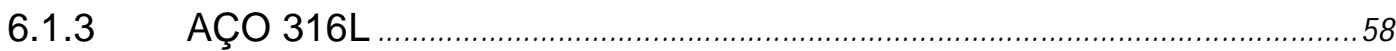

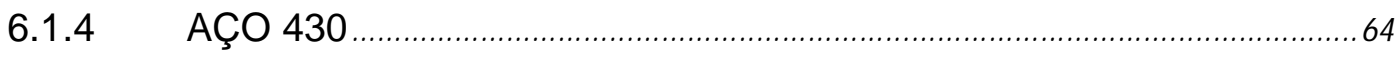

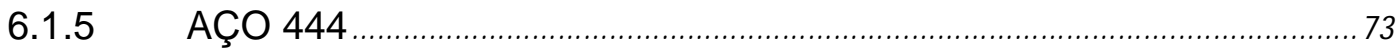

6.2 ENSAIOS DE POLARIZAÇÃO POTENCIODINÂMICA ....................... 82

6.2.1 FORMA DAS CURVAS DE POLARIZAÇÃO OBTIDAS PARA OS

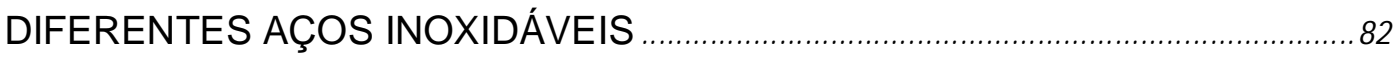

6.3 EXAMES DA NUCLEAÇÃO DOS PITES: SÍTIOS E MORFOLOGIAS 100

6.3.1 SITIOS DE NUCLEAÇÃO DOS PITES ..................................................... 100

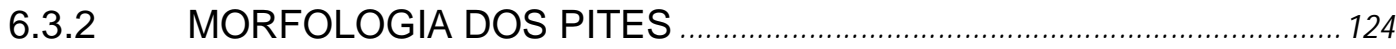

6.4 COMPARAÇÃO DO POTENCIAL DE PITE DOS DIFERENTES AÇOS NOS DIFERENTES ELETRÓLITOS ............................................... 135

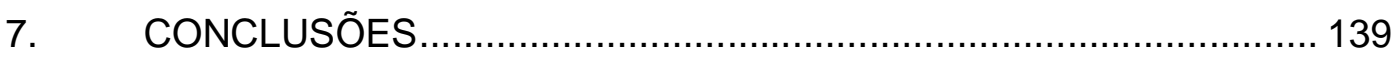

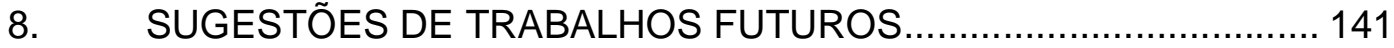

9. REFERÊNCIAS BIBLIOGRÁFICAS ....................................... 142 


\section{INTRODUÇÃO E JUSTIFICATIVA}

A corrosão por pite produz danos severos no material pela exposição em meios agressivos. Os aços inoxidáveis sofrem corrosão por pite em diferentes meios, especialmente aqueles que contêm íons cloreto(1). A corrosão por pite e a película passiva sobre os aços inoxidáveis são fortemente dependentes. Desse modo, é a película passiva que oferece resistência à corrosão à liga que está em contato com ambientes ou meios agressivos(2).

Existem aspectos importantes que influenciam a resistência à corrosão por pite como é o caso das fases secundárias precipitadas e as inclusões não metálicas(1). As fases secundárias podem ser intra ou intergranulares. No caso da formação de inclusões não metálicas como o MnS, que é um sítio preferencial de nucleação do pite, uma explicação, entre outras, está no fato destas inclusões de MnS apresentarem maior contração do que a matriz metálica, durante processos de resfriamento, gerando assim esforços que afetam a película passiva(1).

Diversos estudos têm sido desenvolvidos para tentar explicar o efeito benéfico do molibdênio, como elemento de liga, sobre a resistência à corrosão em meios de cloreto e brometo. Apesar disto, até agora não está completamente entendido o mecanismo pelo qual a resistência à corrosão, do aço inoxidável contendo molibdênio, aumenta quando testados em meios que contém íon cloreto(3).

Quando se consulta a literatura especializada sobre o tema: "resistência à corrosão por pite de aços inoxidáveis", são prontamente encontrados aproximadamente 3200 trabalhos no período de 2000 a 2010 ("base de dados da science direct') onde o íon cloreto é o agente agressivo. Uma parcela menor (290 artigos) trata da influência do íon brometo. Nota-se, portanto, que a maioria das pesquisas é realizada para meios contendo cloreto. Além disso, o custo envolvido na utilização de Ni como elemento de liga em aços inoxidáveis austeníticos, tem voltado a atenção dos produtores, pesquisadores e usuários, para outras alternativas de aços inoxidáveis com baixo teor deste elemento de liga, ou até mesmo sem sua adição. Esta preocupação tem levado ao 
desenvolvimento de novos materiais, tais como o aço inoxidável ferrítico UNS S44400 (portanto, sem adição de Ni) e os aços inoxidáveis austeníticos Cr-Mn, onde parte do $\mathrm{Ni}$ é substituída por $\mathrm{Mn}$, aços estes pertencentes a chamada série 200 (especificação UNS S20100, S20200 e S20500; particularmente, tem-se ainda o aço designado de 298 que é uma especificação da produtora ArcelorMittal Inox Brasil). Tais materiais são potenciais substitutos dos aços inoxidáveis austeníticos mais comercialmente utilizados, que são os aços UNS S30400 e UNS S31603.

No entanto, tais materiais, ainda carecem de pesquisas sobre seus desempenhos, particularmente, quanto à resistência à corrosão por pite, sendo que, questões como a comparação da resistência à corrosão por pite entre os diferentes aços inoxidáveis ainda não estão satisfatoriamente respondidas ou compreendidas. Além disso, conforme mencionado anteriormente, a maioria dos trabalhos de literatura emprega o íon cloreto como agente agressivo.

Os aços inoxidáveis ferríticos têm sido utilizados para algumas partes do sistema de escape de automóveis, devido a suas propriedades em altas temperaturas e sua resistência à corrosão. $\mathrm{Na}$ condensação dos gases de escape são gerados os íons $\mathrm{NH}_{4}{ }^{+}, \mathrm{CO}_{3}{ }^{2-}, \mathrm{SO}_{4}{ }^{2-}, \mathrm{Cl}^{-}, \mathrm{Br}^{-}$e ácidos orgânicos. Uma vez que o íon brometo $\left(\mathrm{Br}^{-}\right)$é um agente agressivo para os aços inoxidáveis, é importante realizar estudos sobre o efeito do íon brometo na resistência à corrosão por pite destes materiais(4).

A partir do exposto, justifica-se a realização da presente pesquisa, que ampliará as informações sobre o tema, permitindo a comparação da resistência à corrosão por pite entre diferentes aços inoxidáveis, além da comparação entre a agressividade de dois íons agressivos: cloreto e brometo. 


\section{AÇOS INOXIDÁVEIS}

\subsection{DEFINIÇÃO}

Os aços inoxidáveis constituem um grupo de aços com uma alta porcentagem de liga, baseado em sistemas de Fe-Cr, Fe-Cr-C e Fe-Cr-Ni. Um aço é inoxidável quando ele tem uma porcentagem de cromo em solução sólida acima de 10,5\% em massa(5). Esta porcentagem de cromo permite a formação de uma película passiva prevenindo assim a oxidação e corrosão do metal exposto em ambientes corrosivos(5).

\subsection{GENERALIDADES DA RESISTÊNCIA À CORROSÃO DOS AÇOS INOXIDÁVEIS}

A corrosão por pite é freqüentemente considerada como um problema entre a susceptibilidade do metal à corrosão por pite e o meio agressivo. Os aços inoxidáveis são amplamente utilizados nas indústrias pela sua passividade, e a falha destes materiais geralmente é associada ao meio que contém cloreto. Embora, não deveria ser esquecido que a maioria dos metais pode sofrer corrosão por pite sob condições específicas(6).

Os materiais resistentes à corrosão não são necessariamente imunes à corrosão por pite, mas são materiais onde a corrosão por pite é mais difícil de acontecer, e isso pode ser indicado pelo alto potencial de pite(14). Os aços inoxidáveis devem sua resistência à corrosão à formação de uma película passiva na sua superfície. Este filme consiste somente de 20 a 30 angstrons de espessura de óxi-hidróxido hidratado de cromo, o qual é extremamente aderente e resistente ao ataque químico(7),(8). Se a película passiva é danificada por abrasão ou riscamento, um processo de repassivação ocorre imediatamente(7).

A resistência à corrosão dos aços inoxidáveis depende de algumas variáveis como: $\mathrm{pH}$, temperatura, meio, composição entre outras. Esta película passiva é formada por óxidos e pode se caracterizar pela sua condutividade 
elétrica e seu comportamento eletroquímico(9). Há, na literatura especializada, muitos estudos de microscopia Auger, os quais confirmam que o principal responsável pela formação da camada passiva nos aços inoxidáveis é o cromo(9).

A resistência à corrosão dos aços inoxidáveis aumenta como o teor de cromo e os materiais são usados em uma ampla variedade de meios agressivos em indústrias químicas e de plantas de processo. Neste contexto, os principais tipos de ataques localizados são: corrosão intergranular, corrosão por pite e corrosão sob tensão(7).

\subsection{INFLUÊNCIA METALÚRGICA DOS ELEMENTOS DE LIGA NOS AÇOS INOXIDÁVEIS}

Os elementos principais de liga para os aços inoxidáveis ferríticos e martensíticos são o cromo e o carbono, e para os aços inoxidáveis austeníticos e duplex é adicionado o níquel. Essencialmente em todos os aços inoxidáveis há teores residuais de processo dos elementos manganês e silício. Outros elementos de liga são o molibdênio, o nióbio, o titânio, o cobre, o tungstênio e nitrogênio, visando melhorar a conformabilidade, desenvolvimento de propriedades especiais e aumento da resistência à corrosão entre outras propriedades(5).

- CROMO

O objetivo principal da adição do cromo é melhorar a resistência à corrosão, no entanto, o cromo é também adicionado para aumentar a resistência à tração do material (aço inoxidável)(10).

Este elemento é um forte formador da fase ferrita, além de formar compostos intermetálicos (fase sigma e chi) os quais tendem a fragilizar o material(5), prejudicando desta forma as propriedades mecânicas e, em certas condições, também a resistência à corrosão. 
- NÍQUEL

A função principal do níquel é promover a fase austenítica, de tal maneira que possam ser produzidas ligas completamente austeníticas ou austeníticasferríticas. Pela adição suficiente do níquel, o campo da fase austenítica é amplamente expandido, permitindo a estabilidade da fase austenítica tanto em temperatura ambiente quanto abaixo dela(5).

O níquel não é um forte formador de carbonetos, e geralmente não promove a formação de fases como a sigma e chi, embora, exista evidência que a presença deste elemento na liga influencia a cinética de precipitação(5).

Tem sido atribuído ao níquel um efeito benéfico na ductilidade dos aços inoxidáveis ferríticos e martensíticos, no entanto, nos aços inoxidáveis ferríticos com alto teor de cromo, adições acima de $2 \%$ em massa de níquel pode reduzir dramaticamente a temperatura de transição dúctil-frágil(5).

\section{- MANGANÊS}

Este elemento de liga nos aços inoxidáveis austeníticos é normalmente adicionado em quantidades de $1-2 \%$ em massa, no entanto, nos aços inoxidáveis ferríticos e martensíticos, o manganês geralmente está presente em teores menores de $1 \%$ em massa.

O manganês é importante para evitar a formação de constituintes eutéticos com baixo ponto de fusão de sulfetos de ferro ( $\mathrm{FeS}$ ), pois este tipo de sulfeto forma trincas de solidificação. Como o manganês reage mais facilmente com o enxofre do que o ferro, a presença de suficiente teor de manganês e a estabilidade do sulfeto de manganês eliminam efetivamente o problema de se formarem microtrincas(5).

\section{- MOLIBDÊNIO}

Este elemento de liga tem sido usado por apresentar efeitos benéficos na resistência à corrosão localizada (pite e fresta) nos aços inoxidáveis. Um 
aspecto metalúrgico no qual este elemento de liga influência nos aços inoxidáveis austeníticos é o melhoramento da resistência à tração em elevadas temperaturas. Isto também tem um efeito negativo, pois as ligas que contêm molibdênio serão mais difíceis para ser trabalhadas a quente(5).

\section{$2.4 \quad$ TIPOS DE AÇOS INOXIDAVÉIS}

A importância dos aços inoxidáveis pede ser apreciada observando-se a produção em toneladas destes tipos de aços no mundo e no Brasil. Na Figura 1 e na Figura 2, esta informação de produção é apresentada. Da Figura 1 se pode observar que a produção mundial dos aços inoxidáveis aumentou consideravelmente nos últimos anos, já na Figura 2, é observado que o aumento não foi tão significativo, embora, após do ano 2005 o consumo desses aços foi mais pronunciados do que os anos anteriores.

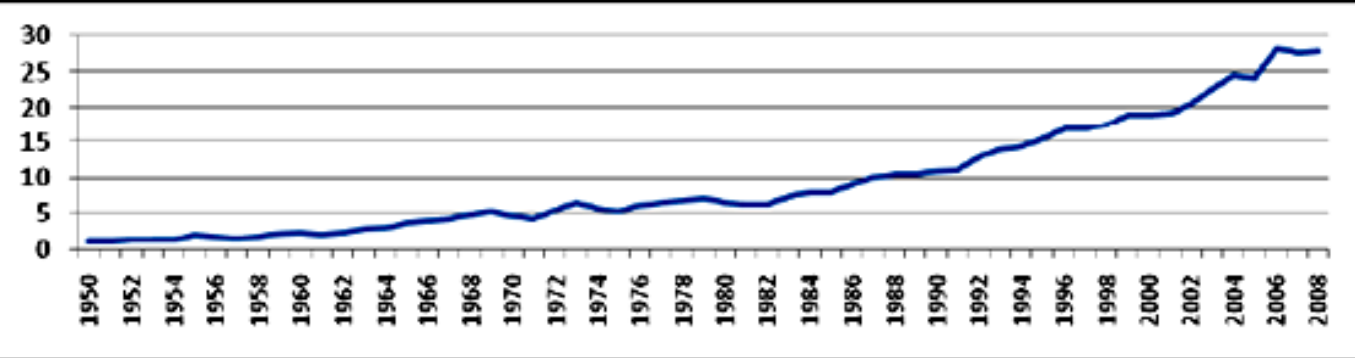

Figura 1 - Evolução da produção mundial de aço inoxidável em milhões de toneladas(11). Modificado. 


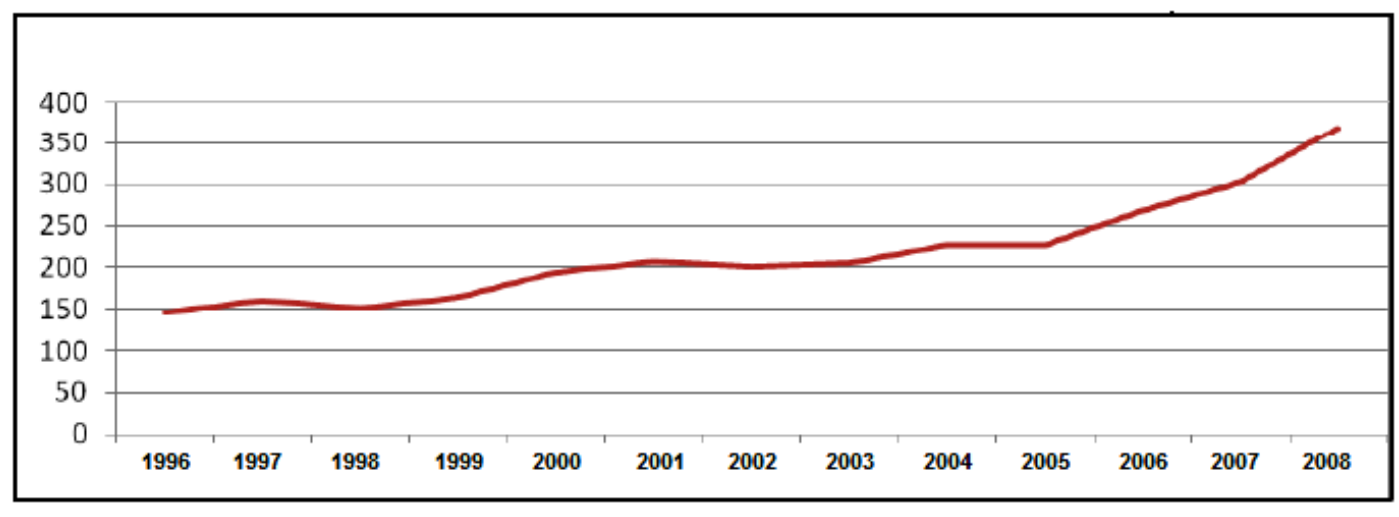

Figura 2 - Evolução da produção Brasileira de aço inoxidável em miles de toneladas(11). Modificado.

Os aços inoxidáveis são classificados em cinco famílias, onde quatro delas são baseadas nos tipos de microestruturas formadas no aço. Estas famílias que compõem os aços inoxidáveis são as seguintes: ferrítico, austenítico, martensítico, duplex (estrutura austenítica + estrutura ferrítica) e endurecíveis por precipitação(12).

Os aços em geral são categorizados por sua composição química, enquanto os aços inoxidáveis são classificados pela formação da fase ou fases metalúrgicas predominantes. As três principais fases possíveis nos aços inoxidáveis, e que dão origem a sua classificação são: a austenita, a ferrita e a martensita(5).

A precipitação dos aços inoxidáveis envolve mudanças nas propriedades dos materiais. Inevitavelmente, uma grande quantidade de componentes de aços inoxidáveis são empregados em altas temperaturas, onde inumeráveis fases poderiam precipitar, prejudicando as suas propriedades(13).

\subsubsection{AÇO INOXIDÁVEL FERRÍTICO}

Os aços inoxidáveis ferríticos são classificados deste modo porque a fase metalúrgica que predomina neste aço é a ferrita (CCC)(5). Estes tipos de aços contêm altos teores de elementos alfagênicos, ou seja, elementos de liga que promovem a formação da fase ferrita. Os principais elementos estabilizadores (alfagênicos) de ferrita são: cromo, molibdênio, vanádio, nióbio e titânio(14). 
Estes tipos de aços possuem boa resistência à corrosão sob tensão, corrosão por pite e corrosão em fresta particularmente em ambiente contendo cloreto(5).

O sistema ternário $\mathrm{Fe}-\mathrm{Cr}-\mathrm{C}$ pode ser utilizado para descrever as transformações de fases que podem ocorrer nos aços inoxidáveis ferríticos. De fato, a sequência de solidificação de um aço inoxidável contendo $17 \% \mathrm{Cr}$ inicia com a formação de ferrita delta, passando por ferrita delta mais austenita, sendo que a diminuição contínua da temperatura gera a precipitação de carbonetos de cromo, terminando, nas temperaturas mais baixas, com uma estrutura de ferrita mais carbonetos(15).

A fase sigma se forma em ligas de $\mathrm{Fe}-\mathrm{Cr}$ contendo $20-70 \% \mathrm{Cr}$ quando exposta em intervalos de temperaturas de 500 a $800^{\circ} \mathrm{C}(5)$. A fase sigma, além de causar endurecimento e a fragilização do material, acaba comprometendo tanto as propriedades mecânicas quanto a resistência à corrosão.

Com um teor de $20 \%$ em massa de $\mathrm{Cr}$ a fase sigma não se forma facilmente, onde será necessário um tempo demasiado prolongado de exposição nas temperaturas críticas de formação desta fase frágil(5). Em ligas de alto teor de cromo, a formação da fase sigma é muito mais rápida, precisando pouco tempo de exposição na faixa de temperatura de formação desta fase(16).

Um exemplo de microestrutura de aço inoxidável ferrítico é apresentada na Figura 3. 


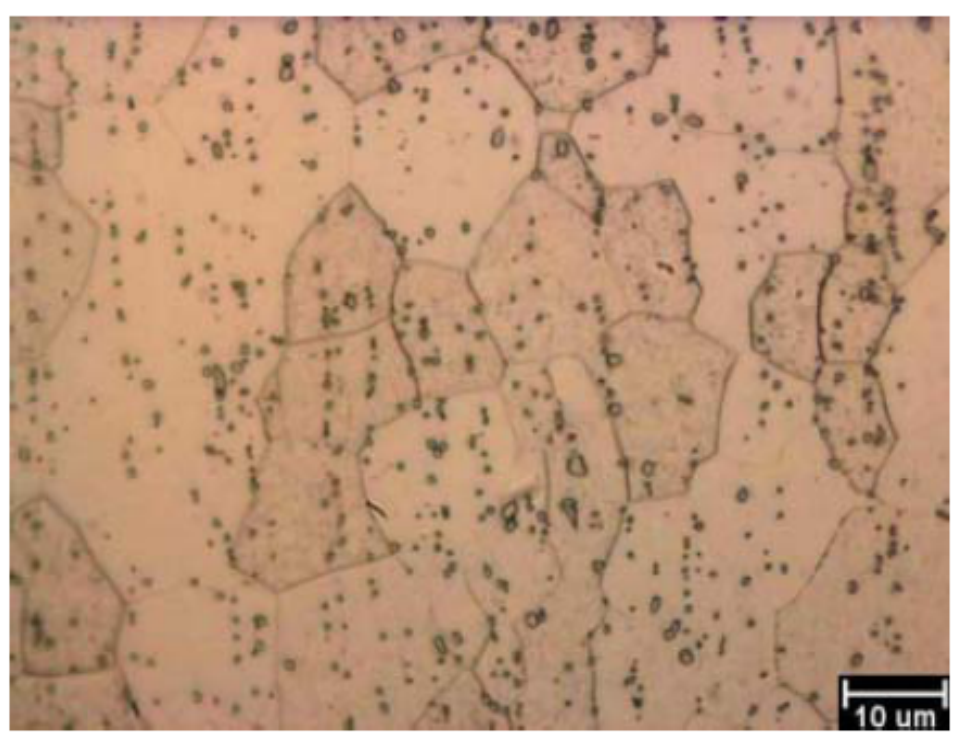

Figura 3 - Microestrutura de aço inoxidável ferrítico 430. A microestrutura é constituída por grãos recristalizados de ferrita com carbonetos de cromo. Ataque químico Vilella(17).

- $\quad$ TIPO 430 (S43000)

Esta liga (aço S43000) é conhecida como "15-chrome", "16-chrome" ou "17-chrome" dependendo da necessidade do usuário. O baixo do teor de cromo melhora as propriedades, tais como, a dureza e resistência ao impacto entre outras, embora, seja sacrificada a resistência à corrosão(18). Este aço é o mais amplamente usado dos aços inoxidáveis ferríticos, pois ele associa uma boa resistência térmica com boas propriedades mecânicas. O aço inoxidável tipo 430 (S43000) é resistente à corrosão sob tensão em meio cloreto, e suas aplicações são encontradas em processamento de alimentos, trocador de calor nas indústrias de petróleo e indústrias químicas(19).

\section{- $\quad$ TIPO 444 (S44400)}

Este é um aço que apresenta na sua composição química teor baixo de carbono e adição do molibdênio para melhorar a resistência à corrosão por pite em meio de cloreto, sendo o teor de cromo na faixa de 17,5 a $19,5 \%$ em 
massa(19). A resistência à corrosão por pite deste aço é similar ao tipo 316 (S31600) e superior ao aço tipo 430 (S43000)(19).

Além disso, este aço contém nióbio e titânio como elementos de liga para estabilizar o carbono, e assim, evitar a precipitação de carbonetos de cromo nos contornos de grão, os quais levam à corrosão intergranular do material.

Esta liga é usada para trocadores de calor em indústrias de petróleo, química e processadoras de alimentos(19).

\subsubsection{AÇO INOXIDÁVEL AUSTENÍTICO}

Os aços inoxidáveis austeníticos apresentam uma variedade de aplicações nas indústrias química, petroquímica, farmacêutica, alimentícia, de biotecnologia e outras, onde a resistência à corrosão seja um fator determinante. A estrutura cristalina destes aços é a cúbica de face centrada (CFC) em temperatura ambiente(20). As principais especificações deste tipo de aço são as UNS S30403 (18 a 20\% em massa de $\mathrm{Cr}$ - 8 a 12\% em massa de Ni) e UNS S31603 (16 a 18\% em massa de $\mathrm{Cr}$ - 10 a $14 \%$ em massa de $\mathrm{Ni}$ - 2 a 3\% em massa de Mo). A microestrutura cristalina dos aços inoxidáveis austeníticos é mostrada na Figura 4.

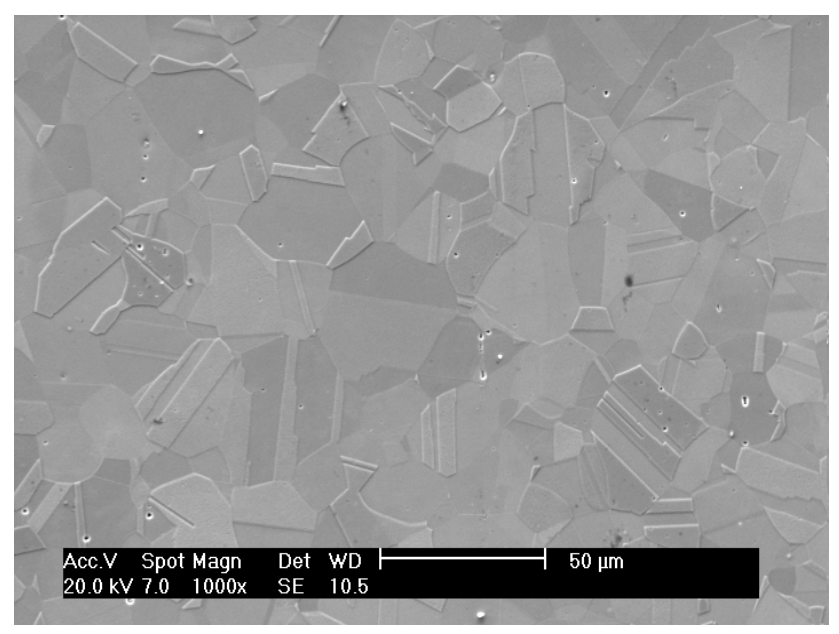

Figura 4 - Micrografia do aço inoxidável austenítico 304. Grãos recristalizados de austenita e maclas de recozimento. 
O principal elemento formador de austenita é o níquel, no entanto, outros elementos como o carbono, o nitrogênio e o cobre, também são gamagênicos. O carbono e o nitrogênio são fortes elementos estabilizadores da austenita, no entanto, o carbono tem a capacidade de melhorar a resistência à fluência em altas temperaturas(5).

Os aços inoxidáveis austeníticos são projetados e processados termo-mecanicamente de tal forma que sua microestrutura primária seja austenita(5). Dependo do balanço de elementos que promovem a formação de austenita e da ferrita, a sua microestrutura pode ser completamente austenítica ou uma mistura de austenita e ferrita(5). Em alguns aços inoxidáveis austeníticos pode acontecer a formação de ferrita residual (formada em altas temperaturas: ferrita delta) alinhados na direção de laminação(5). A formação da fase ferrita delta se deve à segregação de soluto durante a solidificação ou processo termomecânico que promovem este tipo de microestrutura(5). Estes aços são susceptíveis à formação de carbonetos de cromo e de fase sigma particularmente, a partir dos contornos de grão.

Para melhorar a resistência à corrosão são feitas alterações na composição química através da adição de elementos de liga como: molibdênio (aço UNS S31603) e nitrogênio, já que estes elementos têm efeitos benéficos no que se refere à resistência de corrosão por pite dos aços inoxidáveis em meios contendo cloreto(21).

Analogamente ao caso dos aços inoxidáveis ferríticos, uma forma de atenuar o problema de corrosão intergranular é mediante a diminuição do teor de carbono, associada a resfriamentos suficientemente rápidos, ou a estabilização de carbono e nitrogênio, através de elementos de liga tais como o titânio e o nióbio. Estes elementos têm facilidade de reagir com o carbono, formando precipitados em temperaturas mais altas, evitando assim a formação de carbonetos de cromo nos contornos de grão. 


\section{- AÇOS INOXIDÁVEIS DA SÉRIE 200}

Os aços da série 200 foram projetados para obter um ótimo ajuste entre a redução de custos (diminuição do teor de níquel), propriedades de alta conformabilidade (reduzidas adições de $\mathrm{C}, \mathrm{N}$, mas com adição do $\mathrm{Cu}$ ) e propriedades de resistência à corrosão tão próximas quanto possíveis do aço 304(22).

\section{TIPO 298}

Este tipo de aço foi desenvolvido pela empresa ArcelorMittal Inox Brasil, e a sua especificação comercial é o aço inoxidável austenítico 298. Este aço pertence à série 200, onde uma porcentagem do teor de níquel é substituída por manganês. Como não existem extensas informações teóricas acerca deste tipo de material, decidiu-se por abordar o assunto, através de uma pequena descrição das especificações S20100 e S20200, pois a composição química destes aços é similar à composição química do 298.

O aço S20100 é baseado na substituição de níquel por manganês, devido à escassez do níquel durante e logo após da segunda guerra mundial(19). Uma forma clássica de preservar a estrutura CFC é pela adição de níquel, embora, com a adição de manganês combinado com o nitrogênio, é obtido o mesmo efeito e o custo de fabricação é menor(23).

Este aço (S20100) foi desenvolvido como um substituto para o aço inoxidável austenítico tipo \$30400. Pela adição de cerca de 4\% em massa de manganês e 0,2\% em massa de nitrogênio, o teor de níquel poderia ser diminuído a uma porcentagem de $5 \%$ em massa. Quando o teor de níquel é reduzido, o teor máximo possível de cromo será também diminuído, o que significa menor resistência à corrosão, e como conseqüência disto, uma faixa mais estreita das aplicações para as quais este material é apropriado(23). Apesar de este material ter melhor comportamento à tração do que o aço S30400, sua resistência à corrosão é inferior(19). Este material é não magnético quando recozido, mas torna-se magnético depois do trabalho a frio(19). 
Já no aço inoxidável S20200 o teor de cromo, níquel e manganês é maior comparativamente aos teores do aço S20100, o que permitiu uma melhora na resistência à corrosão(19). A Tabela 1 apresenta estas composições químicas.

Tabela 1 - Composição química nominal dos aços inoxidáveis S20100 e S20200.

\begin{tabular}{ccccccc}
\hline \multirow{2}{*}{$\begin{array}{c}\text { AÇO } \\
\text { (UNS) }\end{array}$} & \multicolumn{5}{c}{ COMPOSIÇÃO NOMINAL (\% em massa) } \\
\cline { 2 - 7 } & $\mathbf{C}_{\text {Máx }}$ & $\mathbf{M n}$ & $\mathbf{S i}_{\text {Máx }}$ & $\mathbf{C r}$ & $\mathbf{N i}$ & Outros \\
\cline { 2 - 7 } $\mathrm{S} 20100$ & 0,15 & $4,4-7,5$ & 1 & $16-18$ & $3,5-5,5$ & $0,25_{\text {máx }} \mathrm{N}$ \\
\cline { 2 - 7 } S20200 & 0,15 & $7,5-10$ & 1 & $17-19$ & $4-6$ & \\
\hline
\end{tabular}

A solubilidade do nitrogênio nos aços inoxidáveis depende de três fatores importantes tais como: temperatura, pressão e elementos de liga(24). Para simplificar a análise, são fixadas a pressão parcial de nitrogênio em 1 atm e a temperatura em um intervalo de $1460-1500^{\circ} \mathrm{C}(24)$. Este comportamento é mostrado na Figura 5.

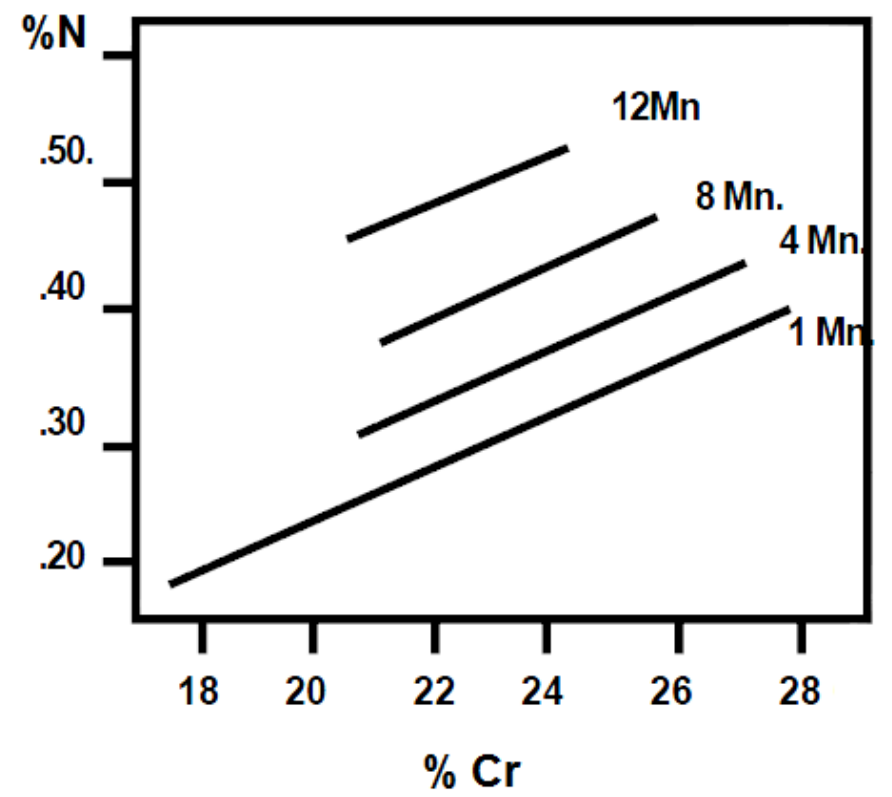

Figura 5 - Efeito da \%Cr e \%Mn sobre a solubilidade do nitrogênio(25). 
Outro aspecto importante nos aços da série 200 é a estabilidade da fase austenita. A estabilidade desta fase (austenita) é função da porcentagem de cromo, níquel e manganês. Este comportamento está mostrado na Figura 6.

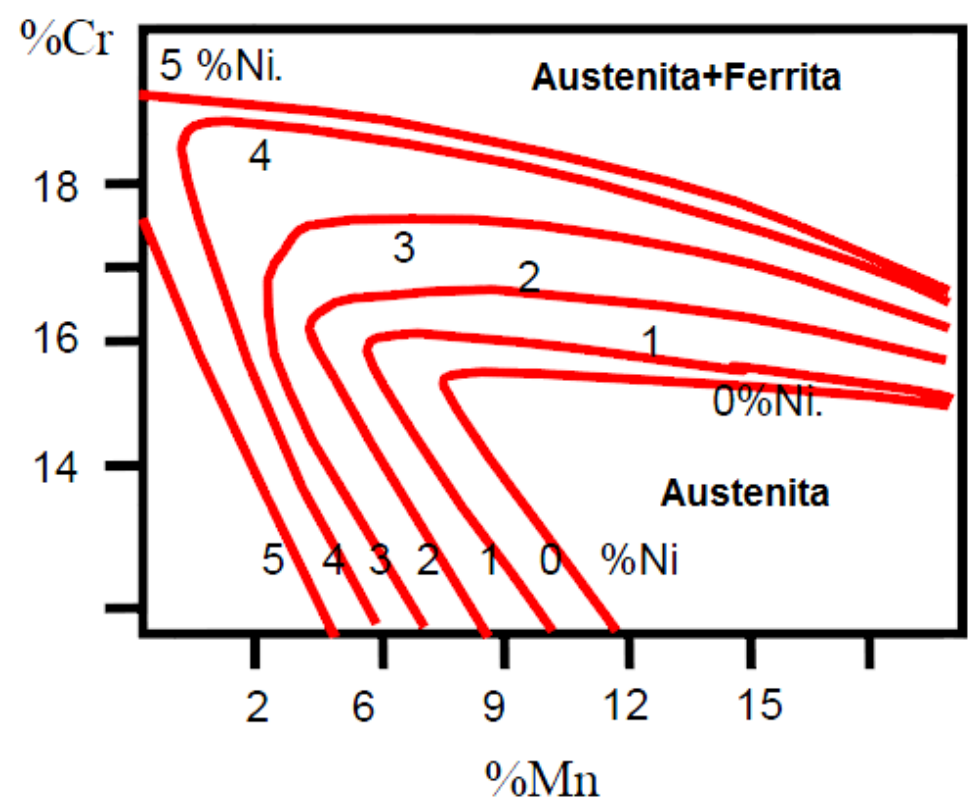

Figura 6 - Estabilidade da fase austenita em $1075^{\circ} \mathrm{C}$ (Franks)(25).Modificado.

\section{- AÇOS INOXIDÁVEIS DA SÉRIE 300}

\section{TIPO 304 (S30400)}

Os aços inoxidáveis austeníticos tipo S30400 são os mais amplamente usados de qualquer aço inoxidável. Embora estes aços tenham um amplo intervalo de resistência à corrosão, eles não são os mais resistentes à corrosão da família dos aços inoxidáveis austeníticos(19).

O aço inoxidável tipo 304 está sujeito à corrosão intergranular como resultado da precipitação de carbonetos de cromo. Se o teor de carbono do aço não excede o $0,03 \%$ em massa (aço 304L), a precipitação de carbonetos 
de cromo pode ser controlada, e estes aços podem ser usados na soldagem sem perigo de precipitação de carbonetos de cromo(19).

\section{$>$ TIPO $316(\mathbf{S} 31600)$}

Uma modificação particularmente notável do aço 316 com o aço 304 é a adição do molibdênio, já que este aço contém na sua composição química este elemento de liga em um intervalo de 2-3\% em massa(18),(19). A maior vantagem do molibdênio como elemento de liga está no aumento da resistência à corrosão por pite e corrosão por fresta em meios que contem íons cloreto(19). Como o molibdênio é um forte estabilizante da fase ferrita, é necessário aumentar o teor de níquel para manter a matriz como fase austenítica(18).

Os aços inoxidáveis tipo 316 contêm um baixo teor de carbono, o que oferece a característica adicional de prevenir a precipitação excessiva de carbonetos de cromo nos contornos de grão(19).

\section{CORROSÃO LOCALIZADA - TIPO PITE}

Segundo LA QUE, cerca de $90 \%$ das falhas que ocorrem por corrosão, estão relacionadas com a corrosão localizada(26). Geralmente a corrosão localizada inclui vários tipos de fenômenos de corrosão tais como o pite, corrosão em fresta e ataque intergranular(27).

Nas últimas duas décadas têm-se visto um aumento considerável no uso de técnicas eletroquímicas para estudar o comportamento de corrosão nos aços inoxidáveis. Do ponto de vista tecnológico, este aumento tem-se estimulado pelo desejo de desenvolver a capacidade de prever 0 comportamento, e/ou estimar a vida útil, dos aços inoxidáveis em ambientes industriais e naturais(21).

Há algum tempo as técnicas eletroquímicas de polarização potenciodinâmica vem sendo utilizada para caracterizar materiais metálicos (sólidos) referente ao problema de corrosão localizada. Essas técnicas são 
amplamente aceitas no meio científico por sua relativa simplicidade com que podem ser conduzidas e por utilizarem metodologias amplamente conhecidas e bem consolidadas(28). Os parâmetros a serem determinados através dos ensaios de polarização potenciodinâmica são: potencial de pite $\left(E_{p}\right)$, potencial de corrosão ( $\left.E_{\text {corr }}\right)$ e potencial de proteção $\left(E_{p p}\right)$. A curva de polarização potenciodinâmica é apresentada na Figura 7.

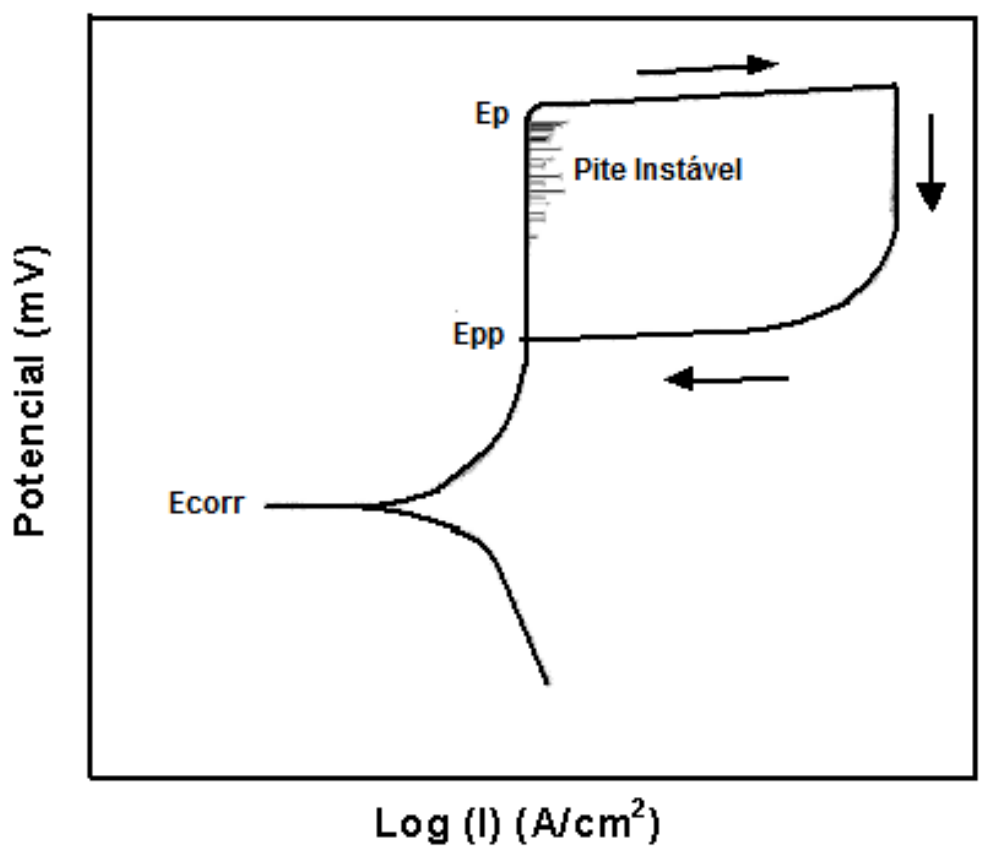

Figura 7 - Esquema da curva de polarização potenciodinâmica mostrando os potenciais críticos(29). Modificado.

Tendo em vista que o objetivo da presente pesquisa é a investigação da resistência à corrosão por pite de diferentes aços inoxidáveis, apresentam-se, a seguir, os principais aspectos encontrados, na literatura especializada, sobre a nucleação e crescimento de pites nesses materiais.

A corrosão por pite é uma forma altamente localizada de corrosão, a qual resulta na formação inicial de cavidades na superfície do metal(7), e que pode se propagar de forma rápida, resultando na perfuração completa do material. Por esta razão, o pite pode ser completamente destrutivo em termos da vida útil do componente metálico, quando somente uma pequena quantidade de metal foi dissolvida por corrosão. Nos aços inoxidáveis, a corrosão por pite 
geralmente tem lugar na presença de íon cloreto(7). A resistência à corrosão por pite aumenta com o teor de cromo, mas o maior efeito benéfico é atribuído à adição de molibdênio em aços inoxidáveis(7).

A resistência à corrosão por pite de aços inoxidáveis é geralmente expressa em termos de "equivalente de resistência à corrosão por pite" (PRE)(7), conforme as equações que estão na Tabela 2 :

Tabela 2 - Equivalente de resistência à corrosão por pite para aços inoxidáveis ferríticos, austeníticos e duplex(1).

\begin{tabular}{ll}
\hline$P R E_{N}=(\% C r)+3,3(\% M o)+30(\% N)$ & Equação 1 \\
\hline$P R E_{N}=(\% C r)+3,3(\% M o)+36(\% N)+7(\% M o)(\% N)-1,6(\% M n)$ & Equação 2 \\
\hline$P R E_{N}=(\% C r)+3,3(\% M o)+16(\% N)$ & Equação 3 \\
\hline$P R E_{N}=(\% C r)+3,3(\% M o+\% W)+30(\% N)$ & Equação 4 \\
\hline
\end{tabular}

A Equação 1 e Equação 2 são utilizadas para os aços inoxidáveis austeníticos e ferríticos, e a Equação 3 e Equação 4 são utilizadas para os aços inoxidáveis duplex.

A corrosão por pite é um problema muito comum para aços inoxidáveis, e uma das principais causas para este indesejável fenômeno poderia ser atribuído à presença de impurezas na composição química do aço(13).

Apesar do grande número de estudos, existe ainda uma controvérsia a cerca do papel das inclusões na formação do pite. Uma delas, é o papel da inclusão não metálica de sulfeto de manganês $(\mathrm{MnS})(13)$. Enquanto o efeito danoso tem sido amplamente reconhecido, o mecanismo exato da corrosão por pite ainda não é identificado(13). As inclusões de sulfeto de manganês não sofrem passivação, o que faz com que se tenha uma descontinuidade na película passiva, sendo estas inclusões um lugar preferencial para a nucleação do pite; particularmente, devido à região da interface $\mathrm{MnS} /$ matriz apresentar corrosão, gerando, localmente, um eletrólito mais agressivo(13),(30). 


\subsection{PELÍCULA PASSIVA}

A passividade é definida como a condição na qual a superfície do metal é resistente à corrosão, em um meio onde a oxidação ocorre pela reação do metal com o ambiente agressivo(31). É sabido que a susceptibilidade dos metais (aços inoxidáveis) aos diferentes tipos de corrosão localizada, está estreitamente relacionada à qualidade da película passiva. Por esta razão, a composição química da película passiva, sua estrutura, espessura e propriedades químicas e físicas são de extrema importância na nucleação do pite(1).

A película passiva atua como uma camada protetora reduzindo dramaticamente a transferência de íons metálicos do metal para o meio ambiente. Mesmo que este filme seja rompido, este filme se regenera em atmosferas oxidantes mantendo assim a propriedade protetora do material(32), (33),(21),(34).

Sobre a ação de íons agressivos, o rompimento da película passiva ocorre principalmente em zonas heterogêneas, causando desta forma a corrosão por pite(3). Alguns autores se referem à melhora da resistência à corrosão por pite com a adição do molibdênio devido ao aumento da resistência da película passiva para se romper, melhorando as características de repassivação(1),(35).

O íon brometo também é conhecido por causar corrosão por pite nos aços inoxidáveis. As adições de molibdênio, neste caso, nem sempre tem efeitos benéficos(35). Bond(36) relatou que a adição de molibdênio melhora os potenciais de pite de $\mathrm{Fe}-18 \% \mathrm{Cr}-\mathrm{X} \% \mathrm{Mo}$ em solução contendo cloreto e brometo. Por sua vez, o molibdênio não aumenta o potencial de pite dos aços inoxidáveis austeníticos em eletrólitos contendo brometo como íon agressivo(35).

Considerando-se a composição química da liga, o molibdênio é um dos principais elementos de liga que aumentam a resistência à corrosão por pite de aços inoxidáveis na presença de cloreto. Uma das dificuldades para se determinar a natureza da sua influência é a complexidade química do molibdênio(3). Acredita-se que o molibdênio poderia ter efeito em mais de um estágio do desenvolvimento do pite, razão pela qual, muitas teorias têm sido 
propostas para explicar a influência do molibdênio(3). Em resumo, a presença e a natureza do molibdênio na película passiva, bem como a explicação do efeito sobre a resistência à corrosão são ainda fortemente debatidos pela comunidade científica(37),(38),(39).

\subsection{MECANISMO DE FORMAÇÃO DO PITE}

O pite é iniciado com a quebra do filme passivo nas regiões mais susceptíveis (inclusões não metálicas, heterogeneidades da película passiva, fases secundárias e contornos de grão entre outros).

O mecanismo para a formação do pite está dividido em dois estágios: o primeiro é a nucleação e o segundo é o crescimento.

\section{NUCLEACÃO DO PITE}

Para que ocorra a nucleação do pite é indispensável que o material esteja em contato com íons agressivos (por exemplo, cloreto e brometo) e potenciais que sejam capazes de produzir uma quebra local da película passiva do metal(1).

Três mecanismos principais são discutidos por vários autores para o processo que conduz à quebra da passividade (rompimento local da película passiva)(40). Os três mecanismos são: o mecanismo de adsorção, o mecanismo de penetração e o mecanismo de quebra do filme.

\section{- MECANISMO DE ADSORCÃO}

Este mecanismo inicia com a adsorção dos ânions agressivos na superfície do óxido, provocando a formação de cátions complexos nesta superfície. A transferência do cátion complexo da camada passiva para o eletrólito é a reação que controla a velocidade do processo(41). 
A adsorção de íons agressivos cloreto incrementa a transferência de cátions metálicos do filme de óxido para o eletrólito, portanto, a dissolução da película passiva ocorre(2).

Este processo é restrito a pequenos pontos energeticamente favoráveis que se encontram no filme de óxido tais como inclusões, discordâncias e outros defeitos superficiais(2).

$\mathrm{Na}$ Figura 8 é apresentado de forma esquemática o mecanismo de adsorção.

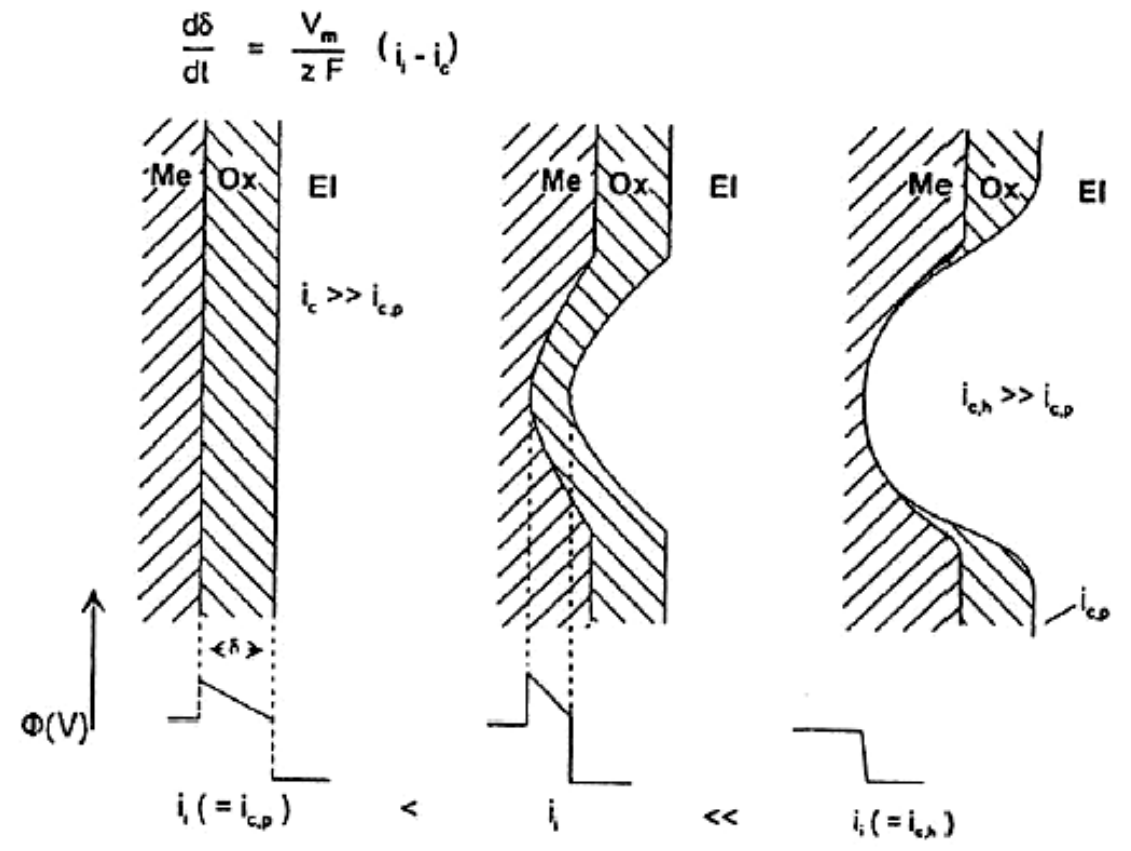

Figura 8 - Representação esquemática do mecanismo de adsorção(42). Modificado.

\section{- MECANISMO DE PENETRACÃO}

O mecanismo de penetração envolve a transferência de ânions agressivos através do filme de óxido à superfície do metal, onde eles começam a sua ação específica. Devido à diferença de potencial (Figura 9) existente entre a interface matriz/óxido e a interface óxido/eletrólito, um campo elétrico é formado, o qual exerce uma força sobre os íons agressivos (no sentido do 
aumento do potencial), facilitando a penetração destes ânions através de imperfeições existentes na camada protetora(42).

O mecanismo de penetração é apresentado de forma esquemática na Figura 9.
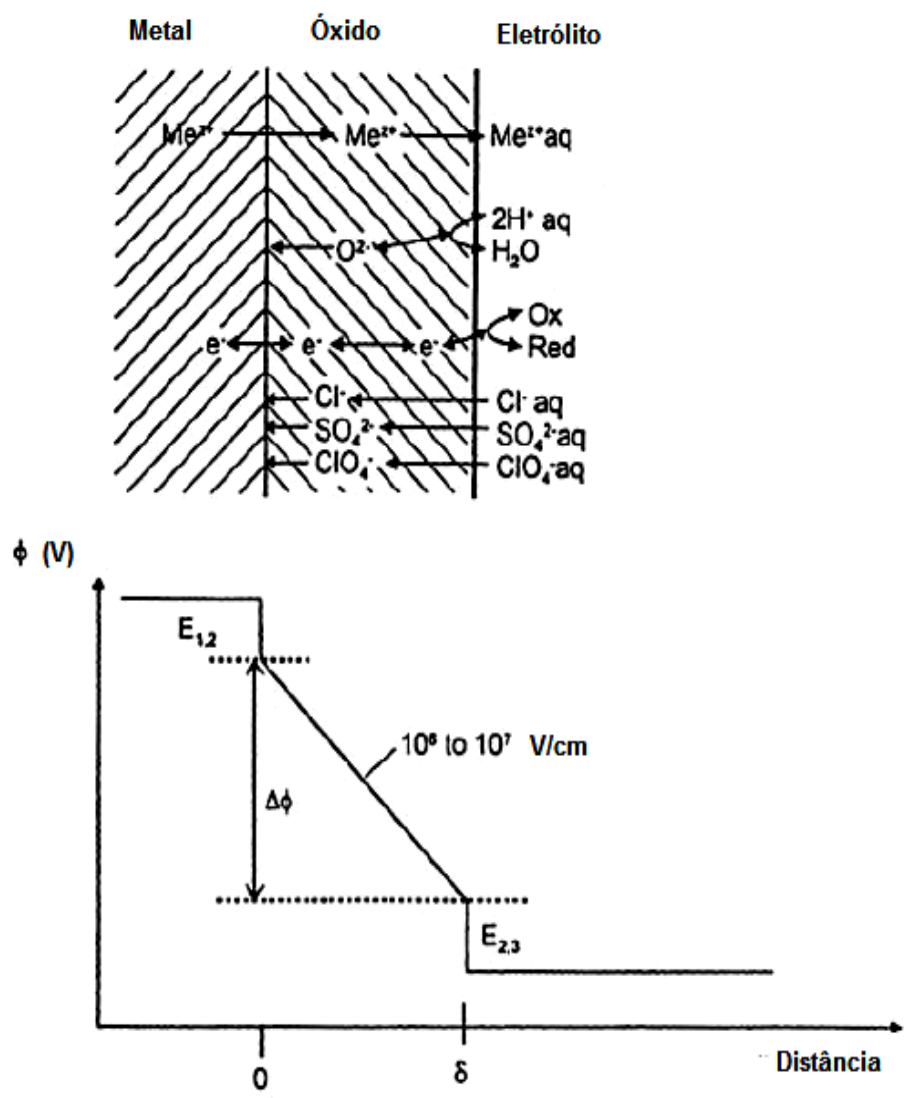

Figura 9 - Representação esquemática do mecanismo de penetração(42). Modificado.

\section{- $\quad$ QUEBRA DO FILME}

A mudança repentina no potencial do eletrodo gera tensões internas dentro do filme passivo, o que pode levar à formação de trincas. As trincas formadas no filme passivo permite que existam um contato direto de pequenas partes da superfície do metal como o eletrólito, e desta forma começa a dissolução do metal(42). 
O mecanismo de quebra do filme está apresentado de forma esquemática na Figura 10.

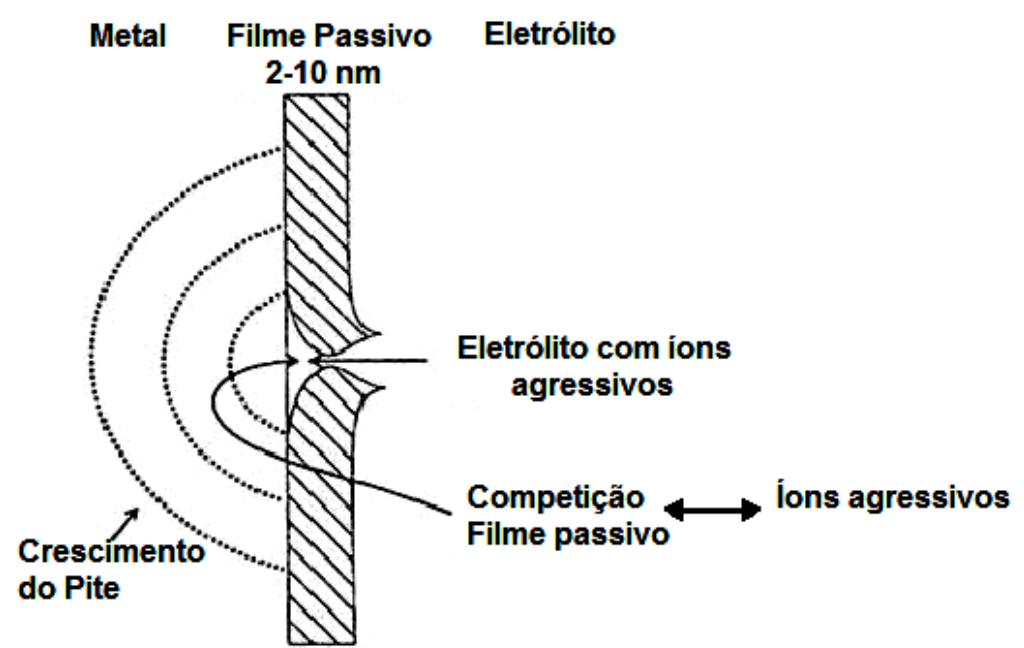

Figura 10 - Representação esquemática do mecanismo de quebra do filme(42). Modificado

\section{CRESCIMENTO DO PITE}

A reação anódica ocorre dentro do pite enquanto que a reação de redução (catódica) do oxigênio ocorre nas superfícies adjacentes. A dissolução do metal que está ocorrendo dentro do pite (Figura 11) tende a produzir um excesso de cargas positivas, o que provoca a migração de íons cloreto para manter a neutralidade elétrica. Assim, dentro do pite existe uma concentração alta de cátions metálicos e íons cloreto. $\mathrm{O}$ cloreto de metal formado $\left(\mathrm{M}^{+} \mathrm{Cl}^{-}\right)$é hidrolisado pela água (Equação 5), formando hidróxidos e ácido ( $\mathrm{HCl}$ ) dentro do pite, o que permite a diminuição do $\mathrm{pH}$ no seu interior. Como os íons hidrogênio e cloreto estimulam a dissolução do metal (aços inoxidáveis), o processo de corrosão é acelerado (se produz uma maior taxa de dissolução do metal). O mesmo mecanismo vale para o caso do íon brometo. 
$\mathrm{M}^{+} \mathrm{Cl}^{-}+\mathrm{H}_{2} \mathrm{O} \rightarrow \mathrm{MOH}+\mathrm{H}^{+} \mathrm{Cl}^{-} \quad$ Equação 5

A reação catódica nas áreas da superfície adjacente ao pite tendem a inibir a formação de pites nesses locais(41); por sua vez, esta área, maior e mais nobre polariza anodicamente a região menos nobre do interior do pite, o que faz que a velocidade de dissolução aumente por efeito galvânico. A Figura 11 apresenta o mecanismo de crescimento do pite.

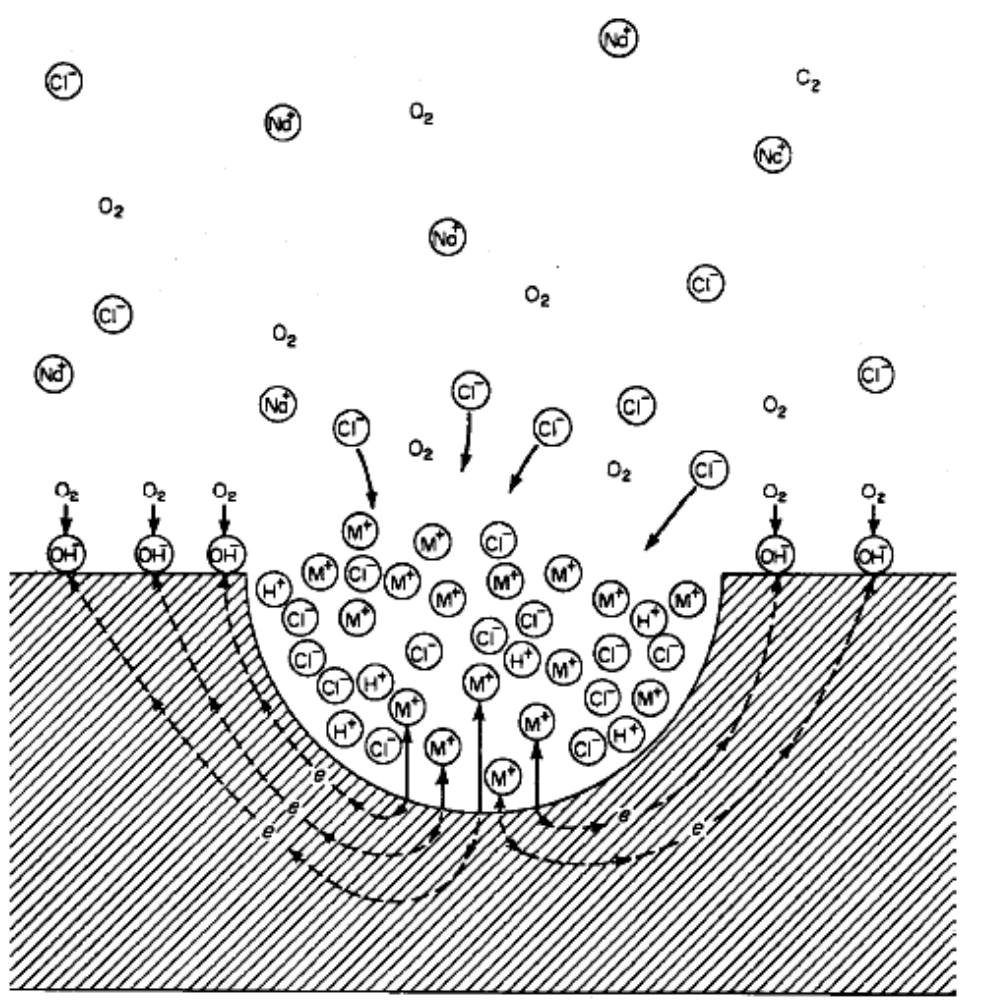

Figura 11 - Mecanismo autocatalítico de crescimento de pite em aços inoxidáveis(43).

\subsection{SÍTIOS DE NUCLEAÇÃO DE PITE}

Na superfície de um metal ou liga, nunca existe a homogeneidade física ou química perfeita. Elementos de liga que melhoram a passividade dos aços inoxidáveis como $\mathrm{Cr}$ e Mo são conhecidos por melhorar a resistência à 
corrosão por pite. As inclusões não metálicas de sulfeto e precipitados de segundas fases são sítios favoráveis para a nucleação de pites em uma grande variedade de ligas de ferro e níquel. Além das inclusões não metálicas e precipitados de fases secundárias, as seguintes características são pontos fracos na película passiva: contornos entre a matriz e a inclusão não metálica, contornos entre a matriz e os precipitados de segundas fases devido à diferença entre os coeficientes de expansão térmica(44).

\section{INCLUSÕES DE SULFETO}

As inclusões de sulfeto são sítios que têm uma grande tendência a formação de pite nos aços ao carbono e aços inoxidáveis. Quando se tem um material que tenha inclusões de sulfeto e outras heterogeneidades, as inclusões serão os principais sítios da nucleação do pite. A formação de inclusões de sulfeto se deve à segregação do enxofre por sua baixa solubilidade no ferro e outros elementos de liga, o qual reage com o manganês, titânio, cromo entre outras formando este tipo de inclusões(44). Em aços inoxidáveis estes tipos de sulfetos são identificados como: $(\mathrm{Cr}, \mathrm{Mn}) \mathrm{S},(\mathrm{Al}, \mathrm{Cr}$, $\mathrm{Mn}) \mathrm{S}, \mathrm{TiS}_{\mathrm{x}}(44)$.

Segundo Poyet e Desestret(45) as formas das inclusões desempenham uma função importante na nucleação do pite. Estudos permitiram encontrar que partículas esferoidizadas são menos susceptíveis que as alongadas (plasticamente deformadas).

Suter(46) estudou a influência das seções expostas das inclusões de MnS alongadas, em aços inoxidáveis austeníticos $18 \mathrm{Cr} 10 \mathrm{Ni}$, através de amostras com diferentes concentrações de enxofre em um eletrólito de $1 \mathrm{M} \mathrm{NaCl}$, na presença e ausência de tensões mecânicas (Figura 12). Suter(46) mostrou que, na presença de tensões mecânicas e inclusões de MnS alongadas, ocorre a formação de pites estáveis (aqueles que nucleiam e crescem continuamente), devido à formação de fresta na interface matriz/MnS, quando a seção exposta é a do comprimento da inclusão. Considerando-se esta mesma seção exposta, na ausência de tensões mecânicas, as inclusões alongadas de MnS agem como sítios de pites instáveis (aqueles que nucleiam e podem se passivar, 
voltando a nuclear e passivar repetidas vezes). Quando a superfície exposta é a da seção transversal, a inclusão alongada de MnS gera uma fresta que acompanha a interface matriz/MnS em sua profundidade, gerando um sítio de nucleação, estreito e profundo, o que provoca a nucleação de pites estáveis. $\mathrm{Na}$ ausência de MnS não ocorre a nucleação de pites, independente da aplicação ou não de tensões mecânicas. Estes casos estão mostrados, de forma esquemática, na Figura 12.

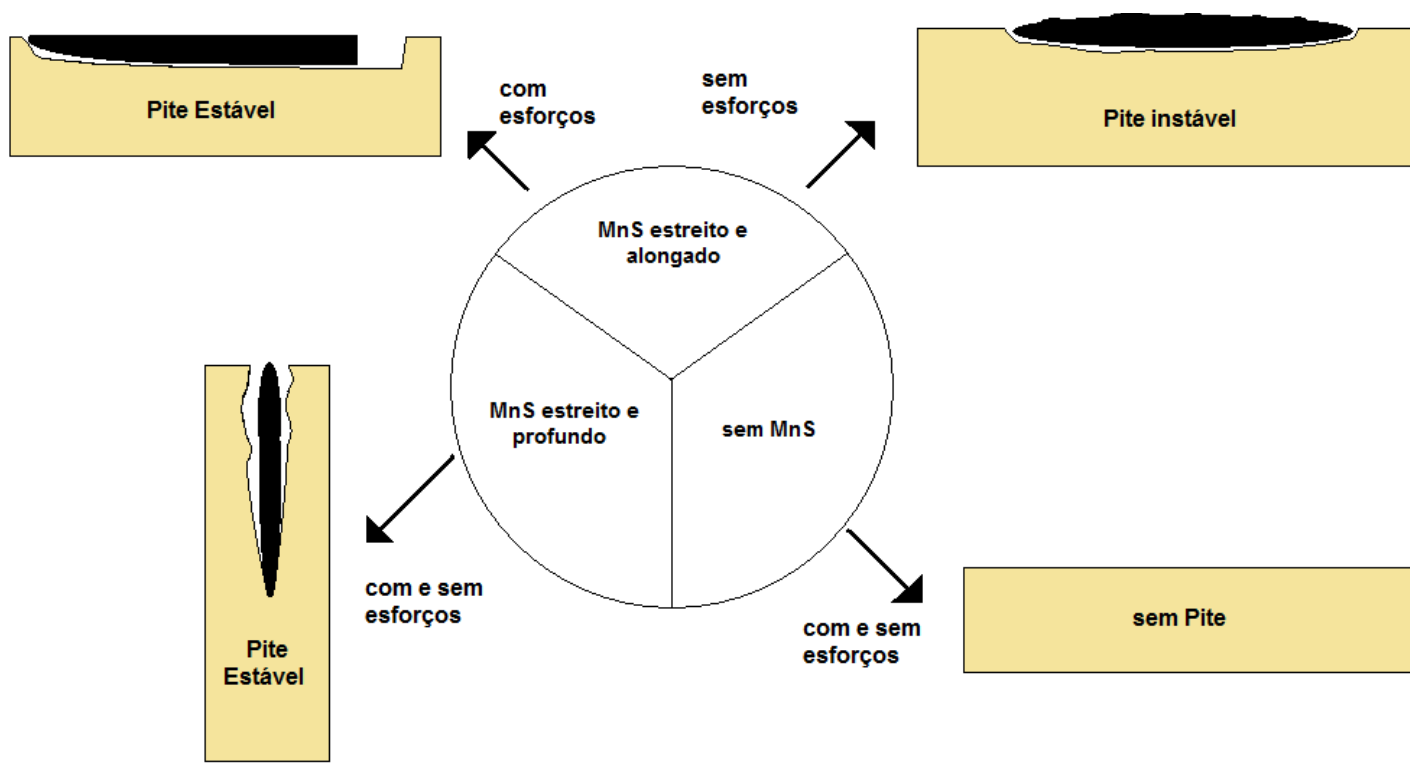

Figura 12 - Influência da forma das inclusões de MnS na nucleação de pites estáveis e instáveis, na presença e ausência de tensões mecânicas. Modificado(46).

$\mathrm{Na}$ iniciação de pite, o sulfeto de manganês tem recebido muita atenção, mais do que outros tipos de inclusões de sulfeto(47). Os cálculos termodinâmicos (diagrama potencial-pH) suportam a idéia que o sulfeto de manganês pode atuar como um sítio de nucleação de pite(48).

Na Figura 13 se observa o diagrama potencial-pH (Potencial de pite vs $\mathrm{pH})$. 


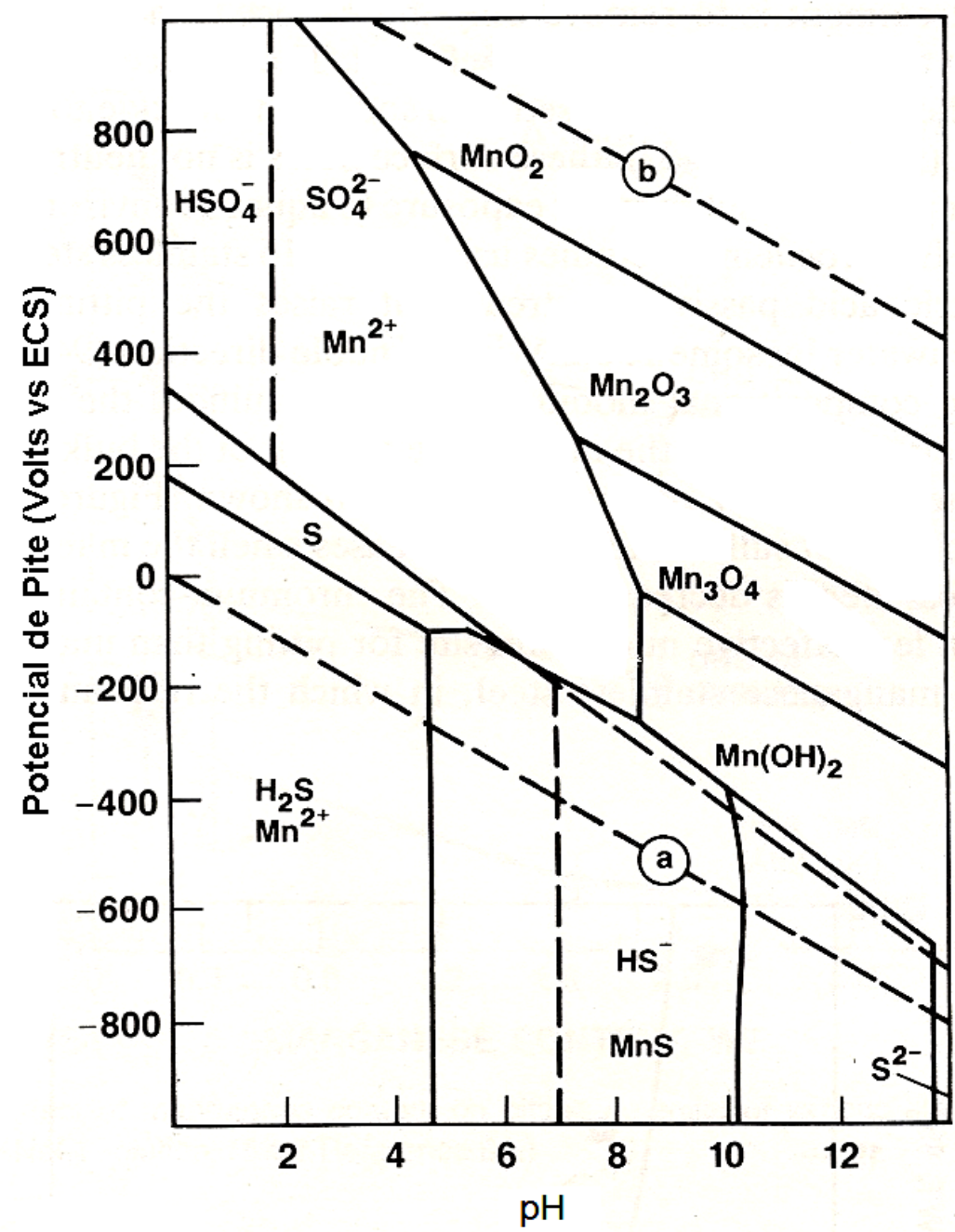

Figura 13 - Diagrama Potencial-pH para um sistema $\mathrm{MnS}-\mathrm{H}_{2} \mathrm{O}-\mathrm{Cl}^{-}$calculado para $0,1 \mathrm{M}$ de íons $\mathrm{SO}_{4}^{-2}, \mathrm{Cl}^{-}$e $\mathrm{Mn}^{+2}$ (48).

Na Figura 13 pode-se observar que o sulfeto de manganês pode existir em um intervalo de $\mathrm{pH}$ de 4,8 até 13,8, em potenciais de até aproximadamente -100 mV (escala de eletrodo de calomelano saturado (ECS)), embora, em potenciais mais nobres, o MnS se dissolve para produzir enxofre e, na sequência, $\mathrm{Mn}^{+2}$ e $\mathrm{SO}_{4}{ }^{-2}$, em pH entre cerca de 4,8 e 8, e em maiores valores de $\mathrm{pH}$, e potencial, há a formação dos óxidos de manganês. Já em valores de $\mathrm{pH}$ menores que 4,8, e baixos potenciais, o sulfeto de manganês é dissolvido para formar $\mathrm{H}_{2} \mathrm{~S}$ e $\mathrm{Mn}^{2+}$. 


\section{CONTORNOS DE GRÃO}

Muitas vezes os contornos de grãos foram considerados ser responsáveis de ser um lugar para a formação do pite, pois diferentes tipos de impurezas são segregados nos contornos de grão, o que faz pensar que isso seja a principal razão para mais alta reatividade de contornos de grão em relação ao grão(44).

\subsection{MEDIDA DA SUSCEPTIBILIDADE À CORROSÃO POR PITE}

O potencial de pite é o potencial no qual começa a crescer estavelmente pelo menos um pite, e é uma das características da susceptibilidade dos metais e ligas à corrosão por pite. A susceptibilidade de um metal ou uma liga à corrosão por pite pode ser estimada das seguintes formas: determinação de potenciais característicos de pite, determinação de uma temperatura crítica de pite, medida do número de pites por unidade de área (densidade de pite), perda de massa, e se for possível a profundidade do pite formado em uma solução normalizada, e a determinação da concentração mínima de íon cloreto que causa pite(44).

A forma de caracterizar a susceptibilidade de um metal à corrosão por pite mediante a densidade de pites, o tamanho e a profundidade são apresentadas na Figura 14.

O potencial de pite é geralmente determinado de acordo com a forma da curva de polarização anódica. O potencial de pite corresponde ao valor do potencial no qual a densidade de corrente aumenta drasticamente em soluções contendo ânions agressivos $\left(\mathrm{Cl}^{-}, \mathrm{Br}^{-}\right.$, entre outros), este valor quantifica a resistência à corrosão por pite de um metal ou liga, em uma dada solução(44). 
A

Densidade

1

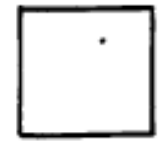

$2.5 \times 10^{3} / \mathrm{m}^{2}$

2

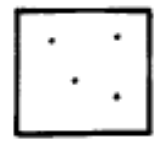

$1 \times 10^{4} / \mathrm{m}^{2}$
B

Tamanho

$0.5 \mathrm{~mm}^{2}$

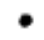

$2.0 \mathrm{~mm}^{2}$

$0.8 \mathrm{~mm}$

C

$0.4 \mathrm{~mm}$

3

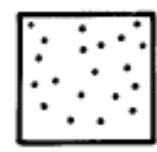

$5 \times 10^{4} / \mathrm{m}^{2}$

$8.0 \mathrm{~mm}^{2}$
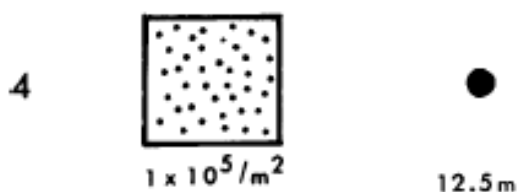

$12.5 \mathrm{~m} \mathrm{~m}^{2}$

5

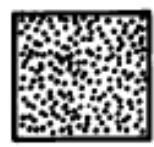

$5 \times 10^{5} / \mathrm{m}^{2}$

$1.6 \mathrm{~mm}$

$3.2 \mathrm{~mm}$

Profundidade
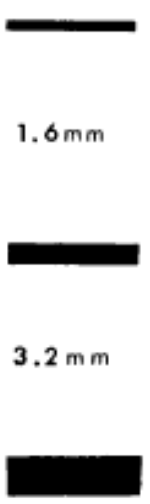

$6.4 \mathrm{~mm}$

Figura 14 - Tabela de classificação padrão para pites(49).Modificado

\subsection{EFEITOS DOS ELEMENTOS DE LIGA}

O efeito de vários elementos de liga sobre a susceptibilidade à formação de pite dos aços tem sido um assunto de algumas pesquisas. De acordo com Kolotyrkin(50), a susceptibilidade ao pite diminui com o aumento dos teores de nitrogênio, níquel e especialmente com o cromo e o molibdênio(44).

Geralmente o cromo e o molibdênio aumentam a resistência à corrosão dos aços em soluções de cloreto. Estes elementos de liga não somente reduzem a susceptibilidade à nucleação de pite, mas também diminuem a taxa de crescimento do pite(44). 
Um efeito benéfico do molibdênio em relação à resistência à corrosão por pite foi encontrado nos aços inoxidáveis ferríticos em solução $\mathrm{NaBr}$ e foi reportado por Bond(1).

Existe uma grande quantidade de elementos de liga que influenciam na resistência à corrosão por pite dos aços inoxidáveis austeníticos em meio cloreto. Estes elementos são apresentados na Figura 15.

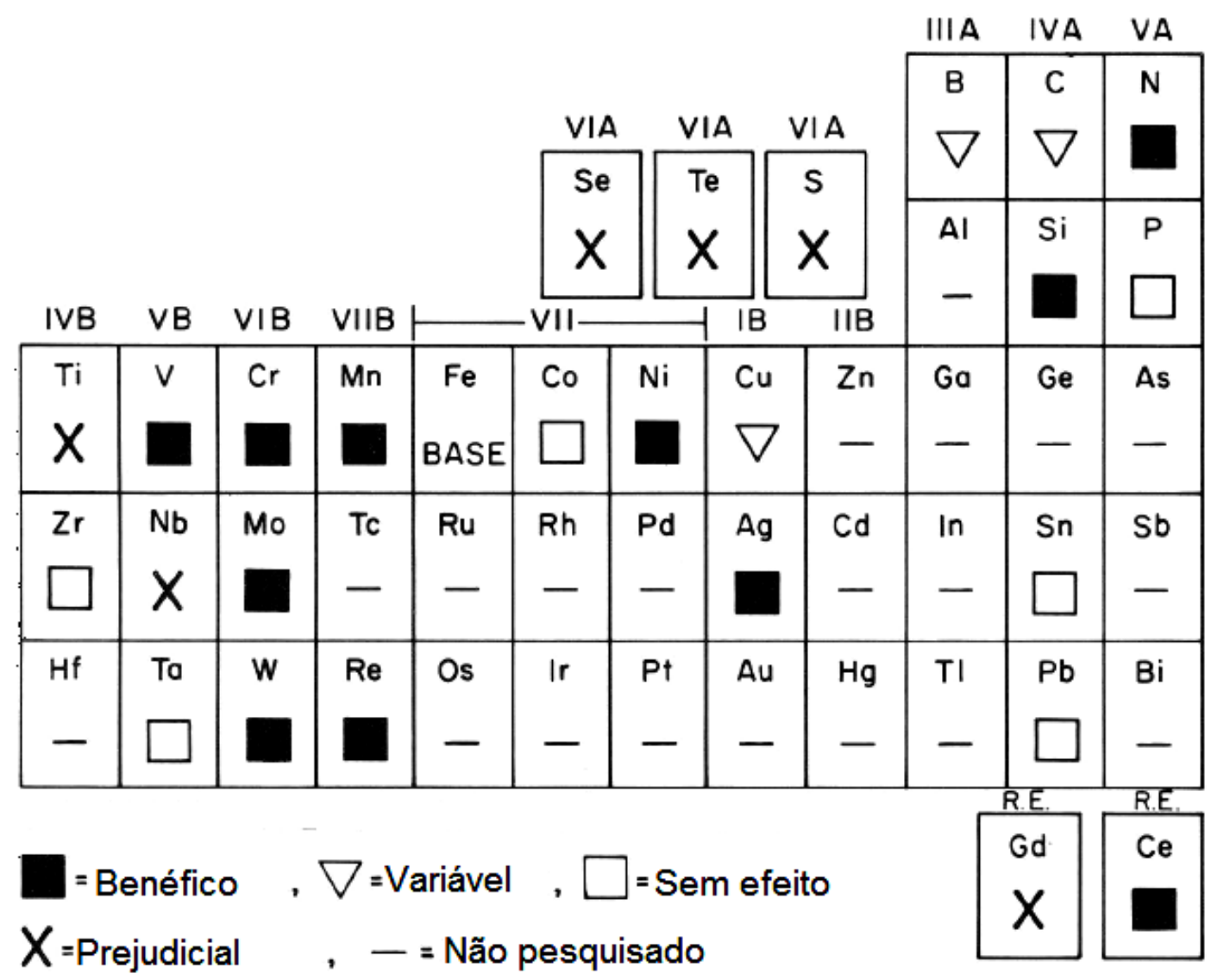

Figura 15 - Efeito de alguns elementos químicos sobre a resistência à corrosão por pite em solução de cloreto(21).Modificado.

\section{CROMO}

As propriedades que distinguem os aços inoxidáveis de outros materiais resistentes à corrosão dependem essencialmente do cromo(51). Quando o teor 
de $\mathrm{Cr}$ em solução sólida excede 10,5\% em massa, o aço é considerado inoxidável sob condições ambientais, no entanto, para ambientes mais agressivos são necessários teores maiores de cromo(52). Este elemento de liga é principalmente adicionado para aumentar a resistência à corrosão do material, pois com a adição do $\mathrm{Cr}$, um óxido estequiométrico $(\mathrm{Fe}, \mathrm{Cr})_{2} \mathrm{O}_{3}$ é formado na superfície do aço(5). Na Figura 16 é mostrado o comportamento do potencial de pite em função do teor de cromo.

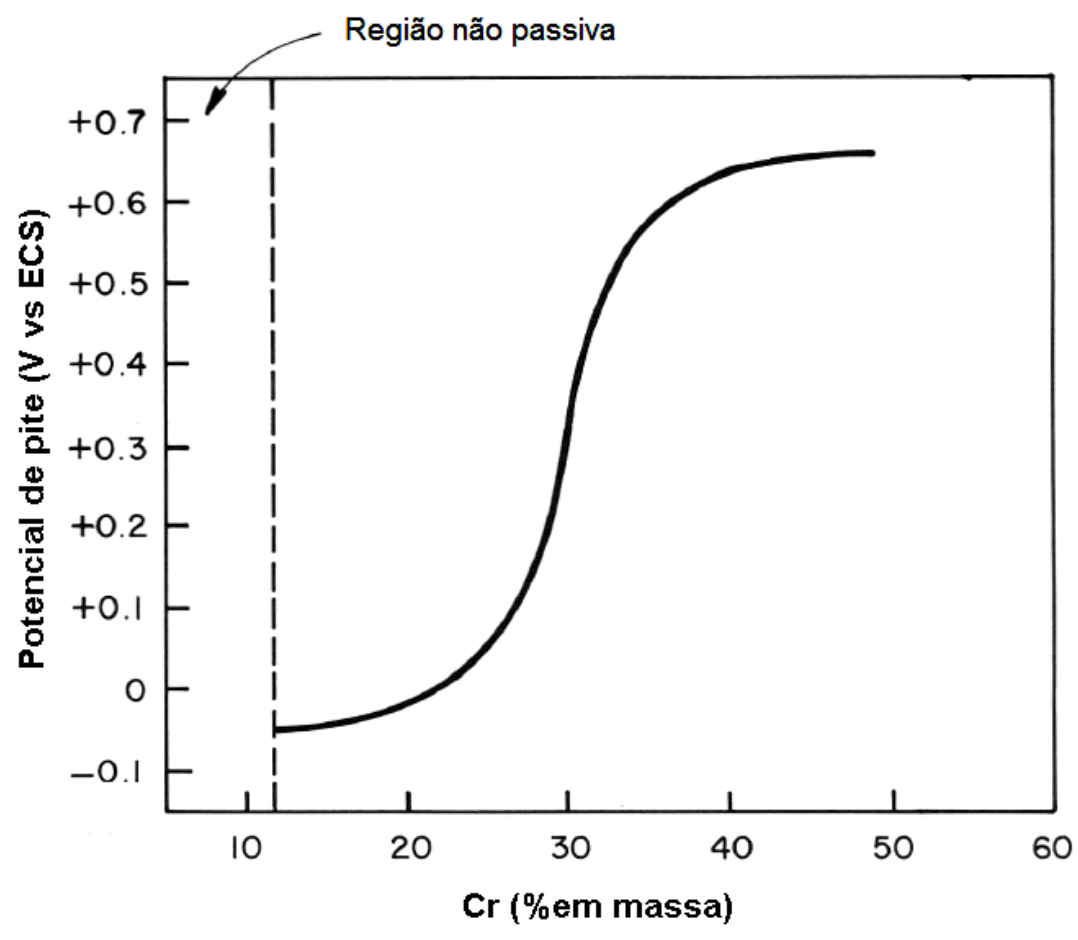

Figura 16 - Efeito do teor de cromo sobre o potencial de pite em liga $\mathrm{Fe}-\mathrm{Cr}$ em solução desaerada de $0,1 \mathrm{~N} \mathrm{NaCl}(53)$. Modificado.

\section{MOLIBDÊNIO}

O molibdênio é usado em aços inoxidáveis em quantidades de até $8 \%$ em massa, no entanto, é mais comumente encontrado em teores de $2-4 \%$ em massa. Mesmo em teores relativamente pequenos, este elemento tem 
poderosos efeitos no aumento da resistência à corrosão por pite em ambientes contendo o íon cloreto para os aços inoxidáveis ferríticos e austeníticos(51).

Wegrelius \& Olefjord (1995)(54) reportaram que o íon cloreto $\left(\mathrm{Cl}^{-}\right)$é uniformemente distribuído na camada passiva dos aços Fe20Cr20Ni. Segundo os autores, o íon agressivo $\left(\mathrm{Cl}^{-}\right)$presente na camada passiva provavelmente

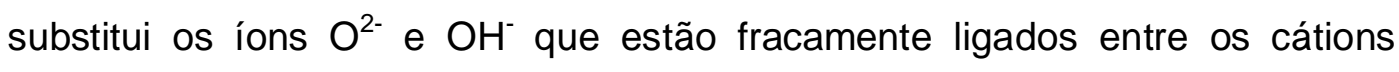
metálicos $\left(\mathrm{Me}^{+\mathrm{z}}\right)$ e o oxigênio, conduzindo ao enfraquecimento da camada passiva e facilitando desta forma a dissolução do metal(54).

A influência do molibdênio na resistência à corrosão por pite em meio cloreto reside na formação de oxicloretos complexos solúveis e clorohidroxidos de Mo (Mo-Chlorohydroxide) complexos insolúveis em água, o que reduz a quantidade de íons de cloreto na camada passiva, retardando o processo de dissolução do metal(54).

A Figura 17 mostra o potencial de pite em função do teor de molibdênio.

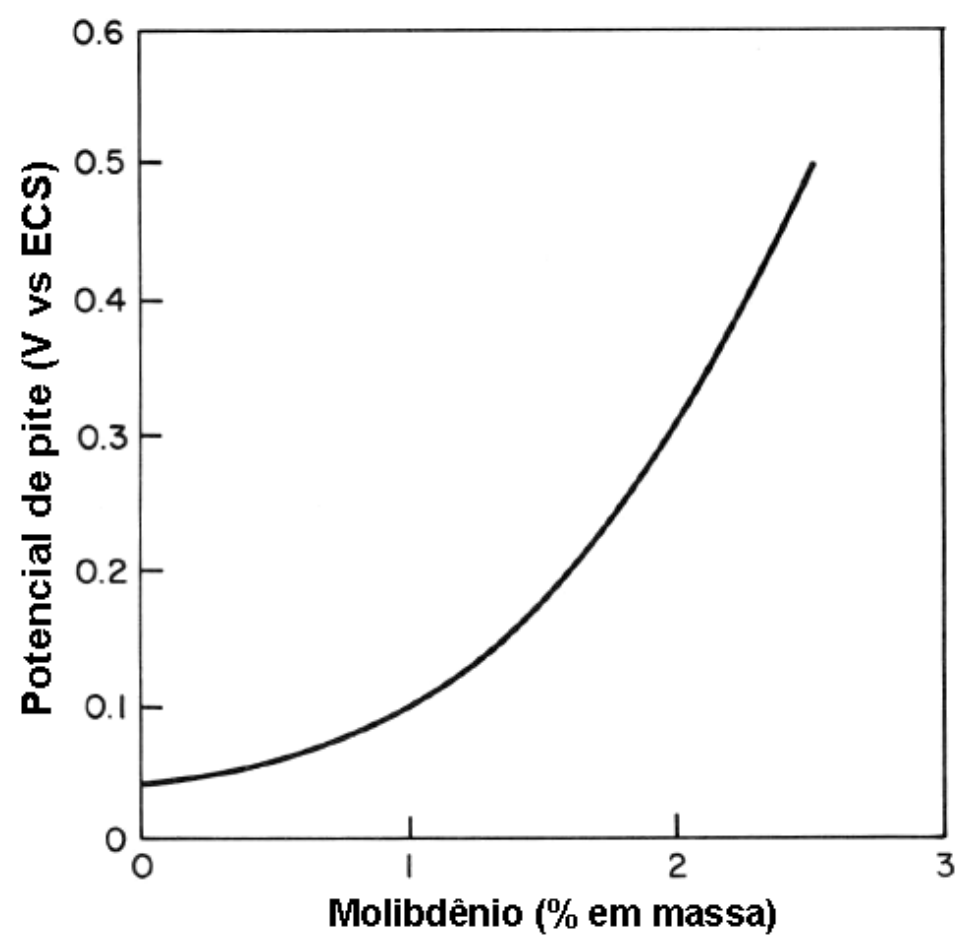

Figura 17 - Efeito do teor de molibdênio sobre o potencial de pite de ligas Fe-15Cr-13Ni em solução desaerada $0,1 \mathrm{~N} \mathrm{NaCl}$ em $25^{\circ} \mathrm{C}$ (53).Modificado. 


\section{NIÓBIO E TITÂNIO}

A corrosão intergranular (sensitização) dos aços inoxidáveis ferríticos pode ser prevenida pela adição de elementos estabilizadores, tais como: Ti e $\mathrm{Nb}$. Esses elementos têm uma forte reatividade com o $\mathrm{C}$ e $\circ \mathrm{N}$, precipitando carbonetos e nitretos de $\mathrm{Ti}$ e/ou $\mathrm{Nb}$, os quais são mais estáveis quando comparados com os carbonetos de $\mathrm{Cr}(55),(17)$.

A relação entre os elementos estabilizadores e os elementos intersticiais foi determinada experimentalmente para a liga $18 \% \mathrm{Cr}-2 \% \mathrm{Mo}$, como é mostrado na Equação 6(56), onde, a adição de $\mathrm{Ti}$ ou $\mathrm{Nb}$ no teor assim determinado, é suficiente para impedir a corrosão intergranular desse aço:

Ti ou $N b=0,2 \%+4(\% C+\% N)$

Equação 6

Lee (52) determinou que o aço $\mathrm{Fe}-17 \% \mathrm{Cr}$ estabilizado com titânio ou nióbio é imune à corrosão intergranular quando apresenta uma relação entre $\mathrm{Ti}$ ou $\mathrm{Nb}$ e $(\mathrm{C}+\mathrm{N})$ maior que nove, como é apresentado na Equação 7 :

$\frac{\% T i}{(\% C+\% N)}=\frac{N b}{(\% C+\% N)}>9 \quad$ Equação 7

\section{NITROGÊNIO}

É geralmente aceito que a adição do nitrogênio como elemento de liga tem uma influência benéfica sobre a resistência à corrosão por pite nos aços inoxidáveis(1).

O nitrogênio dissolvido no aço inoxidável austenítico aumenta a resistência à corrosão por pite em meios contendo cloreto (57),(58). O mecanismo pelo qual a resistência à corrosão por pite é melhorada seria(58) a dissolução do nitrogênio presente em solução sólida produzindo $\mathrm{NH}_{4}{ }^{+}$, aumentando $\circ \mathrm{pH}$ local e permitindo que o pite entre na região de passivação(59). 


\section{INFLUÊNCIA DO MECANISMO COMBINADO DO MANGANÊS E DO MOLIBDÊNO NA CORROSÃO POR PITE}

Tobler e Virtanen, (2006) mostram que o pH local diminui durante a dissolução de inclusões de MnS, levando à dissolução do Mo, com conseqüente formação de óxidos nas bordas do pite, favorecendo desta forma o processo de repassivação(60). A Figura 18 apresenta uma região com a presença de óxido de molibdênio.

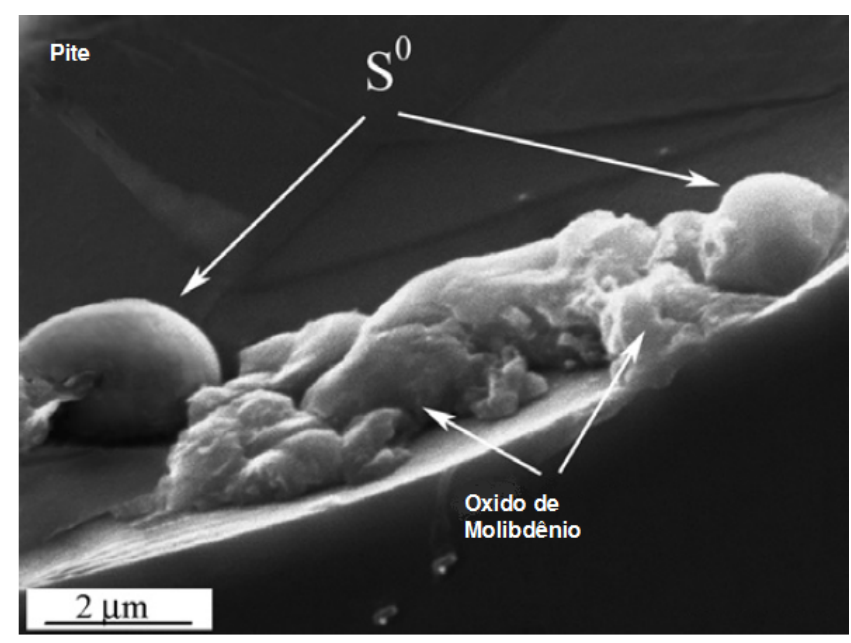

Figura 18 - Exames em MEV de um pite formado no aço 316 $\mathrm{L}$ com alto teor de molibdênio $(2,74 \% \mathrm{Mo}$ e $0,98 \% \mathrm{Mn})$ após polarização potenciodinâmica em solução aquosa de $3,5 \% \mathrm{NaCl}$ até o potencial próximo ao potencial de pite(3). Modificado.

De acordo com o diagrama de Pourbaix (Figura 19), a formação de $\mathrm{FeMoO}_{4}$ é predominante em condições ligeiramente acidas (pH 4-6). Este fato tem lugar na região do pite mais próxima da superfície metálica. No interior do pite o $\mathrm{pH}$ assume valores próximos de 2(61), onde o $\mathrm{FeMoO}_{4}$ é instável, e o $\mathrm{MoO}_{3}$ que é estável. Desse modo, a formação de $\mathrm{MoO}_{3}$ é favorecida no interior do pite. Sendo assim, os autores(3) sugerem que o $\mathrm{MoO}_{3}$ deva ser o principal composto envolvido com o processo de repassivação(3). 


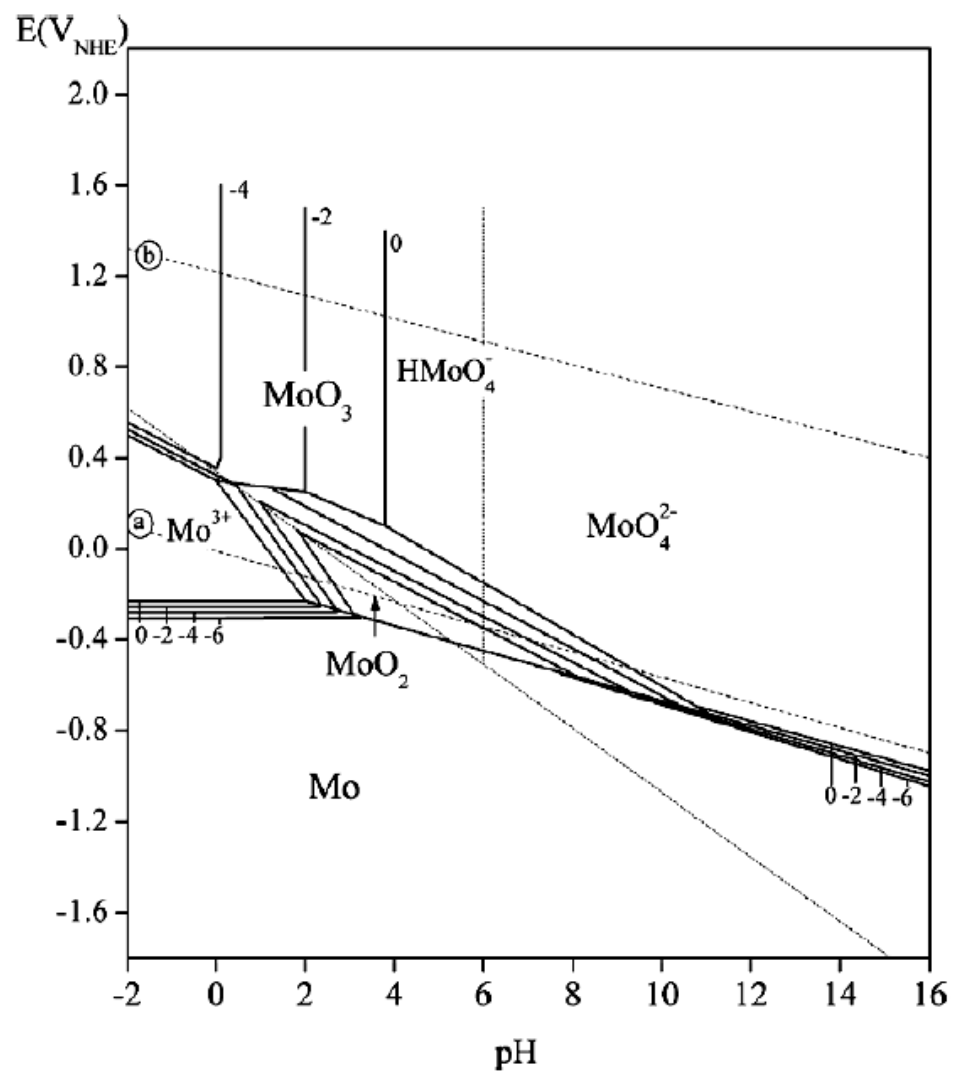

Figura 19 - Diagrama de Pourbaix para o sistema de $\mathrm{Mo}-\mathrm{H}_{2} \mathrm{O}$ a $25^{\circ} \mathrm{C}$ (3).Modificado.

Para a compreensão da participação do manganês e do molibdênio no mecanismo da corrosão por pite dos aços inoxidáveis, alguns autores têm proposto um mecanismo em três estágios, levando em conta a função do sulfeto como iniciador da corrosão por pite, e as mudanças das propriedades de repassivação devido à presença de molibdênio como elemento de liga nos aços inoxidáveis(3). Tais estágios são: dissolução parcial do sulfeto de manganês (MnS), dissolução dos elementos de liga da matriz e formação de óxidos de molibdênio(3). A seguir, são apresentados alguns detalhes dessas etapas:

- DISSOluÇão PARCIAL DO MnS: Em ambientes neutros contendo cloreto e dentro da região de passividade dos aços inoxidáveis, as inclusões MnS são termodinamicamente instáveis e tendem a se dissolver. 
Durante a dissolução destas inclusões, a superfície do aço é revelada e começa o ataque localizado nesta área(3). Este estágio é ilustrado na Figura 20.

\section{$\bullet$}

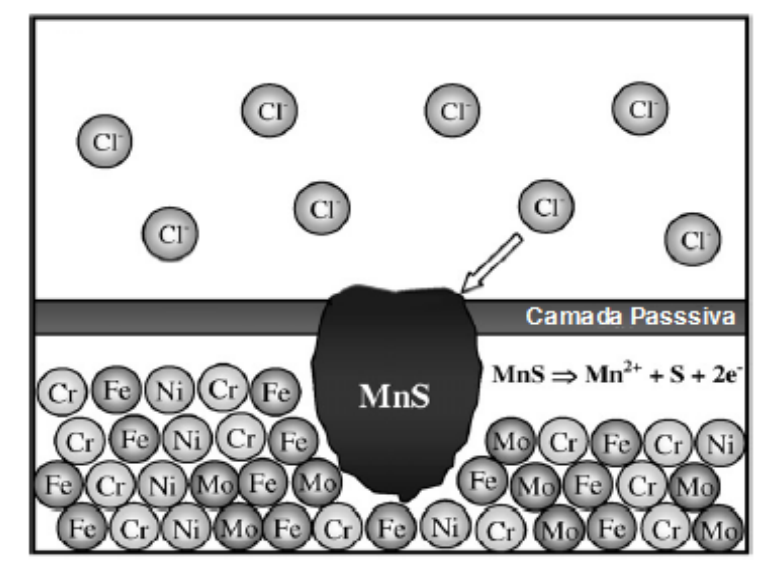

Figura 20 - Primeiro estágio do mecanismo do efeito combinado do Mn e Mo sobre a corrosão por pite dos aços inoxidáveis austeníticos em meios contendo cloreto(3).

- DISSOlUÇÃo dOS ELEMENTOS DE LIGA DA MATRIZ: Neste estágio ocorre a dissolução do material (inclusão e aço), o qual resulta na geração de espécies catiônicas dos elementos de liga, tais como, $\mathrm{Fe}^{+2}, \mathrm{Ni}^{+2}, \mathrm{Cr}^{+2} \mathrm{e}$ particularmente $\mathrm{Mo}^{+2}$. A reação de hidrólise dessas espécies favorece a diminuição local do pH para valores ácidos(3). Este processo está mostrado de forma esquemática na Figura 21. 


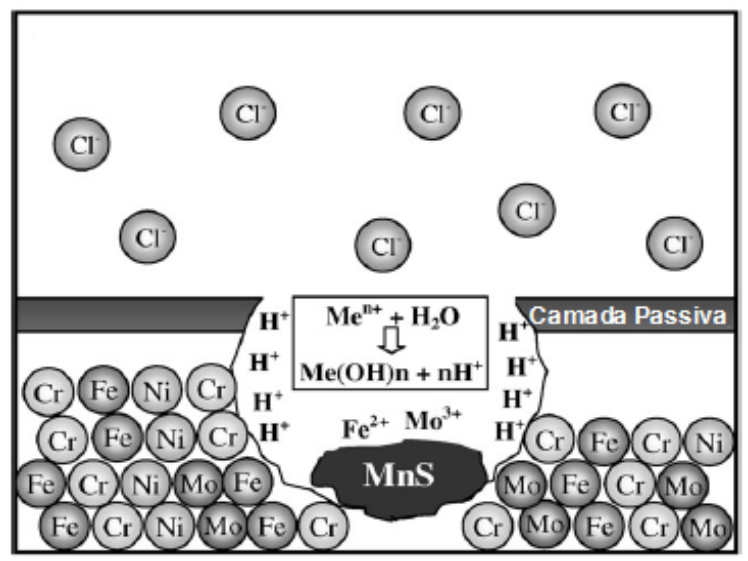

Figura 21. Segundo estágio do mecanismo do efeito combinado do Mn e Mo sobre a corrosão de pite dos aços inoxidáveis austeníticos em meios contendo cloreto (3).

- FORMAÇÃO DE ÓXIDOS DE MOLIBDÊNIO: Na maioria dos casos sobre essas condições, em pH baixos e valores de potenciais altos, as espécies $\mathrm{Mo}^{+3}$ são oxidadas e o molibdênio alcança os estados mais altos de oxidação $\mathrm{Mo}(\mathrm{VI})$. Neste estado de oxidação, o molibdênio reage mais facilmente para formar compostos insolúveis e altamente estáveis tais como $\mathrm{FeMoO}_{4}$, mas geralmente existe a formação de $\mathrm{MoO}_{3}$ (Figura 22) o qual recobre parcialmente ou completamente a parede do pite. Como resultado disto os pites neste estágio são repassivados e a possibilidade de atingir o estágio de crescimento contínuo de pite é reduzida.

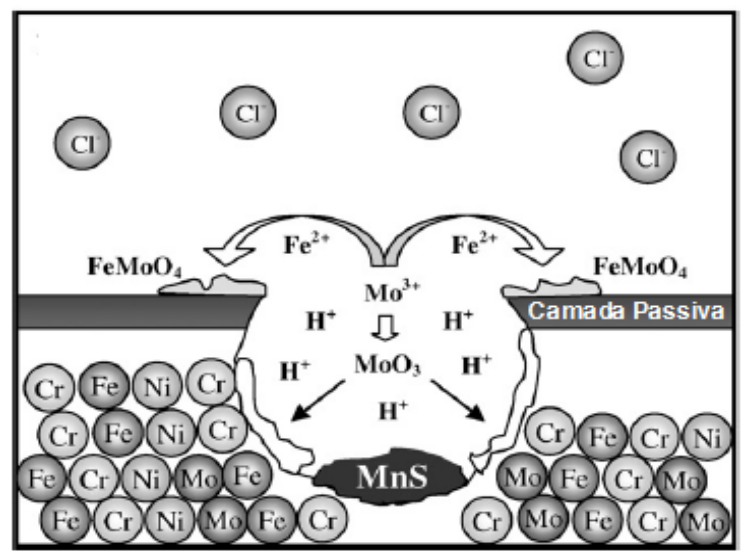

Figura 22 - Terceiro estágio do mecanismo do efeito combinado do Mn e Mo sobre a corrosão de pite dos aços inoxidáveis austeníticos em meios contendo cloreto (3). 


\section{OBJETIVOS}

O objetivo do presente trabalho é investigar a resistência à corrosão por pite de

diferentes aços inoxidáveis austeníticos (298, 304 e 316L) e ferríticos (430 e 444) em presença de cloreto e brometo. 


\section{MATERIAIS E MÉTODOS}

\subsection{MATERIAIS}

Os aços inoxidáveis utilizados no presente trabalho são: 298 (aço inoxidável Cr-Mn, especificação da ArcelorMittal Inox Brasil) e os aços padronizados segundo a UNS: S30400, S31603, S43000 e S44400.

Neste trabalho os materiais serão identificados por: 298 304, 316L, 430 e 444 , respectivamente. As amostras de 298, 430 e 444 foram recebidas como doação da ArcelorMittal Inox Brasil, na forma de chapas com dimensões de $210 \mathrm{~mm} \times 240 \mathrm{~mm}$ e espessuras indicadas na tabela 4 , juntamente com a composição química que foi fornecida pela própria doadora. Já as amostras de 304 e 316L estavam disponíveis no Laboratório de Processos Eletroquímicos do Departamento de Engenharia Metalúrgica e de Materiais da USP (LPE/PMT) e tiveram suas análises químicas realizadas nos laboratórios do SENAI-Osasco-SP.

Nas Tabela 3 e Tabela 4 é mostrada a composição química e a espessura das chapas dos aços utilizados para este trabalho respectivamente.

Tabela 3 - Composições químicas (\% em massa) e espessuras dos aços inoxidáveis utilizados no presente trabalho.

\begin{tabular}{|c|c|c|c|c|c|}
\hline \multirow{2}{*}{ ELEMENTOS } & \multicolumn{5}{|c|}{ COMPOSIÇÃO QUÍMICA DOS AÇOS (\% em massa) } \\
\hline & 298 & 304 & $316 L^{*}$ & 430 & 444 \\
\hline $\mathrm{C}$ & 0,0427 & 0,062 & 0,017 & 0,047 & 0,0141 \\
\hline $\mathrm{Cr}$ & 17,134 & 18,087 & 15,164 & 16,24 & 17,57 \\
\hline $\mathrm{Ni}$ & 4,776 & 8,089 & 9,708 & 0,24 & $0,621^{*}$ \\
\hline $\mathrm{Mn}$ & 5,690 & 1,174 & 1,571 & 0,35 & $0,165^{\star}$ \\
\hline $\mathrm{Si}$ & 0,322 & 0,47 & 0,591 & 0,4 & $0,581^{*}$ \\
\hline $\mathrm{Al}$ & 0,0037 & 0,001 & 0,004 & -- & $0,015^{\star}$ \\
\hline$S$ & 0,0018 & 0,002 & 0,007 & 0,002 & 0,0006 \\
\hline$P$ & 0,0315 & 0,028 & 0,045 & 0,027 & $0,031^{*}$ \\
\hline Mo & 0,0240 & 0,049 & 2,18 & - & 1,825 \\
\hline $\mathrm{Ti}$ & 0,0050 & 0,003 & 0,006 & 0,002 & 0,174 \\
\hline $\mathrm{Nb}$ & 0,0224 & 0,007 & 0,016 & 0,004 & 0,023 \\
\hline $\mathrm{Cu}$ & 1,5470 & 0,079 & 0,1 & --- & --- \\
\hline Co & 0,0597 & 0,078 & 0,046 & --- & --- \\
\hline $\mathrm{N}$ & 0,0996 & 0,086 & --- & 0,03 & 0,0136 \\
\hline W & 0,0241 & 0,008 & --- & -- & ---- \\
\hline V & 0,0657 & 0,045 & 0,032 & ---- & ---- \\
\hline
\end{tabular}

*Análise química realizada no SENAI-Osasco. 
Tabela 4 - Espessura das chapas de aço utilizadas para a caracterização metalográfica a para os ensaios de corrosão.

\begin{tabular}{ccccc}
\hline \multicolumn{5}{c}{ ESPESSURA DAS CHAPAS DE AÇO $(\mathrm{mm})$} \\
\hline $\mathbf{2 9 8}$ & $\mathbf{3 0 4}$ & $\mathbf{3 1 6 \mathrm { L }}$ & $\mathbf{4 3 0}$ & $\mathbf{4 4 4}$ \\
\hline 1,1 & 1,7 & 1,6 & 1,6 & 0,7 \\
\hline
\end{tabular}

\subsection{PREPARAÇÃO DOS CORPOS-DE-PROVA}

Foram utilizados dois tipos de corpos-de-prova: corpos-de-prova metalográficos, para a caracterização de inclusões e microestrutural e corposde-prova planos para os ensaios de corrosão em potenciostato.

Para a caracterização metalográfica as amostras foram cortadas em equipamento de corte a disco. Após o corte, os corpos-de-prova foram embutidos a quente usando uma resina termofixa (baquelite). Após a etapa de embutimento foi realizado o lixamento do corpo-de-prova, utilizando-se a politriz manual. Neste equipamento foram usadas lixas d'água que são fixadas nos discos rotativos, com granulometria de 100 , seguida pelas lixas 220,320 , $400,600,1000$ e 1200. A troca da lixa é feita quando é obtida uma superfície uniforme, sendo necessário girar a amostra em $90^{\circ}$, para iniciar com a lixa seguinte.

Para a caracterização das inclusões, os corpos-de-prova com acabamento de lixa 1200 passaram por polimento fino, utilizando-se abrasivos (pastas de diamante) de 6,3 e $1 \mu \mathrm{m}$. Sobre o pano de polimento são depositadas pequenas quantidades de pasta de diamante e a lubrificação é realizada com álcool e água destilada. A troca do pano de polimento é feita quando é obtida uma superfície uniforme e sem riscos do procedimento anterior. Este passo foi repetido até conseguir-se um polimento sem risco na superfície da amostra.

Para a caracterização microestrutural, os corpos-de-prova com acabamento de lixa 1200 passaram por polimento eletrolítico com ácido 
perclórico $5 \%$, sob uma tensão de $40 \mathrm{~V}$ por um tempo de 30 segundos. Sendo posteriormente levados ao ataque eletrolítico, descrito mais adiante.

O formato do corpo-de-prova utilizado para a caracterização metalográfica é mostrado na Figura 23.

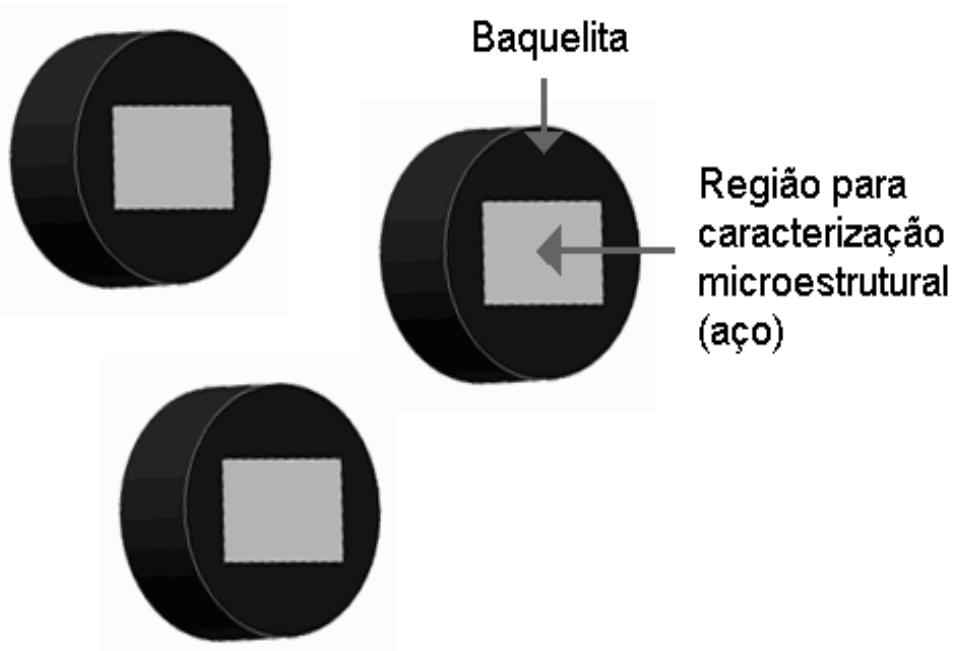

Figura 23 - Corpo-de-prova (embutido em baquelite) utilizado para a caracterização microestrutural.

Para os ensaios de polarização potenciodinâmica foi utilizado um corpode-prova plano, com dimensões de $40 \mathrm{~mm} \times 210 \mathrm{~mm}$ (Figura 24). O ensaio era feito na superfície da face das chapas originais. Este corpo-de-prova permitia a realização de vários ensaios na superfície preparada, apenas, deslocando-se aproximadamente $2 \mathrm{~cm}$ de cada região ensaiada. Os corpos-de-prova de todos os aços deste estudo tiveram suas superfícies lixadas com lixas de granulometria100, seguida pelas lixas 220,320, 400 e 600. Imediatamente antes de cada ensaio, a superfície era novamente lixada com lixa 600, lavada e secada em jato de ar. Em seguida, o corpo-de-prova era posicionado na célula eletroquímica (célula plana), que era preenchida com o eletrólito desejado. 


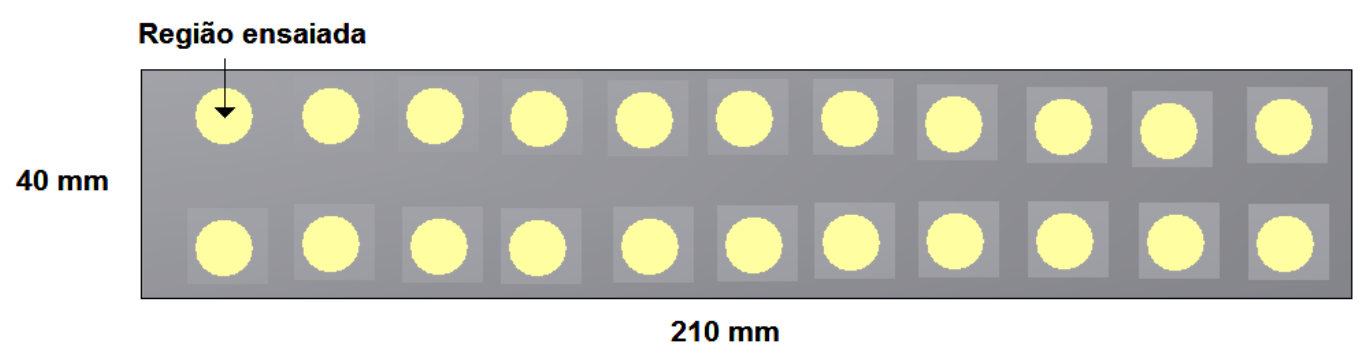

Figura 24 - Esquema dos corpos-de-prova para os ensaios de polarização potenciodinâmica.

\subsubsection{CARACTERIZAÇÃO METALOGRAFICA}

Uma vez obtida a superfície sem riscos, com o polimento eletrolítico, foi realizado o ataque eletrolítico para revelar a microestrutura dos aços. Este ataque eletrolítico foi feito com ácido oxálico 10\% para os aços inoxidáveis austeníticos e ferríticos. Foi empregada uma voltagem de $6 \mathrm{~V}$ por um tempo de 20 segundos. Este ataque foi baseado na norma ASTM A262 (prática A) que é utilizada para a dissolução de fases ricas em cromo, com o objetivo de se identificar carbonetos de cromo em aços inoxidáveis. No presente caso, o ataque foi realizado apenas com o objetivo de se revelar a microestrutura, sendo por isso, um ataque menos intenso que o original da norma ASTM A262.

A caracterização microestrutural foi realizada com 0 auxílio do microscópio eletrônico de varredura (MEV), principalmente para analisar a composição química das inclusões e precipitados através de análises com o sistema de dispersão de energia (EDS).

\subsubsection{ENSAIO DE CORROSÃO}

\subsubsection{PREPARAÇÃO DOS ELETRÓLITOS}

Para determinar a resistência à corrosão por pite foram realizados ensaios de polarização potenciodinâmica em eletrólitos contendo cloreto e brometo. 
Os eletrólitos empregados no presente trabalho estão indicados na Tabela 5. Optou-se por manter-se constante a concentração iônica das espécies agressivas (cloreto e brometo). A partir do trabalho de Maria Luisa Murillo y Martin et al.(62) escolheu-se a concentração total de 0,6M. Desse modo, foram preparados eletrólitos puros de $\mathrm{NaCl}$ e $\mathrm{NaBr}$, bem como misturas, segundo as concentrações da Tabela 5. Foram utilizados reagentes PA (para análise) e água destilada e deionizada.

Tabela 5 - Composição química dos eletrólitos utilizados nos ensaios de polarização potenciodinâmica.

\begin{tabular}{cc}
\hline Eletrólito & Composição Química \\
\hline 1 & $0,6 \mathrm{M} \mathrm{NaCl}$ \\
2 & $0,45 \mathrm{M} \mathrm{NaCl}+0,15 \mathrm{M} \mathrm{NaBr}$ \\
3 & $0,3 \mathrm{M} \mathrm{NaCl}+0,3 \mathrm{M} \mathrm{NaBr}$ \\
4 & $0,6 \mathrm{M} \mathrm{NaBr}$ \\
\hline
\end{tabular}

\subsubsection{ENSAIOS DE POLARIZAÇÃO POTENCIODINÂMICA}

Para os ensaios eletroquímicos foi utilizada uma célula plana e um potenciostato PAR 273A Princeton Applied Research, que são conectados a um microcomputador que controla e armazena os dados do ensaio. A célula possui uma janela que tem formato circular com uma área exposta de $1 \mathrm{~cm}^{2}$ que tem como objetivo expor a superfície do material ao eletrólito. A polarização foi iniciada após 5 minutos de imersão a partir do potencial de corrosão estabelecido nesse instante, com uma velocidade de varredura de $1 \mathrm{mV} / \mathrm{s}$. $\mathrm{O}$ ensaio era interrompido quando a densidade de corrente atingia um valor aproximado de $10^{-3} \mathrm{~A} / \mathrm{cm}^{2}$. O acabamento superficial adotado foi o de lixa 600. A temperatura foi monitorada e manteve-se em $(26+/-3)^{\circ} \mathrm{C}$. Cabe ressaltar que cada sistema aço/eletrólito foi ensaiado pelo menos 5 vezes, o que permitiu obter o valor médio e o desvio-padrão do Ep.

O corpo-de-prova é chamado de eletrodo de trabalho. Para o controle das leituras de potencial de eletrodo, foi empregado o eletrodo de referência de 
prata/cloreto de prata $(\mathrm{Ag} / \mathrm{AgCl})$. Uma rede confeccionada com finos fios de platina foi utilizada como contra-eletrodo. $O$ formato de rede oferece área suficientemente grande para permitir as reações gasosas durante a polarização. A polarização foi realizada e controlada através de software do próprio fabricante do potenciostato: 352 Softcorr III.

\subsection{MORFOLOGIA DE CORROSÃO E SÍTIOS DE NUCLEAÇÃO DE PITES}

Após os ensaios potenciodinâmicos, os corpos-de-prova eram lavados e secados com jato de ar para exames da superfície atacada (corroída) em MEV.

Os pites obtidos foram fotografados e quando possível, foi realizada análise química por EDS para identificação dos elementos presentes no interior dos pites.

Para a identificação dos sítios de nucleação de pite, os corpos de prova foram lixados até uma granulometria de 1200, lavados e secados em jato de ar. Em seguida, foi realizado o ensaio de corrosão, o qual foi interrompido quando era atingida uma densidade de corrente de aproximadamente $10^{-5} \mathrm{~A} / \mathrm{cm}^{2}$. Após o ensaio de corrosão, estas amostras foram cortadas e levadas ao MEV para a análise da superfície corroída. 
6. RESULTADOS EXPERIMENTAIS E DISCUSSÃO

\subsection{CARACTERIZAÇÃO MICROESTRUTURAL}

$\mathrm{Na}$ caracterização do material inclui-se a identificação da microestrutura dos aços utilizados e a composição química das inclusões. Esta caracterização foi feita em MEV (Microscópio Eletrônico de Varredura) utilizando-se análises de energia dispersiva (EDS).

\subsubsection{AÇO 298}

Para a caracterização microestrutural do aço 298 , foi feito o polimento do corpo-de-prova até $1 \mu \mathrm{m}$. O aspecto da superfície sem ataque está apresentado na Figura 25, onde se nota a presença de inclusões não metálicas com formatos globulares.

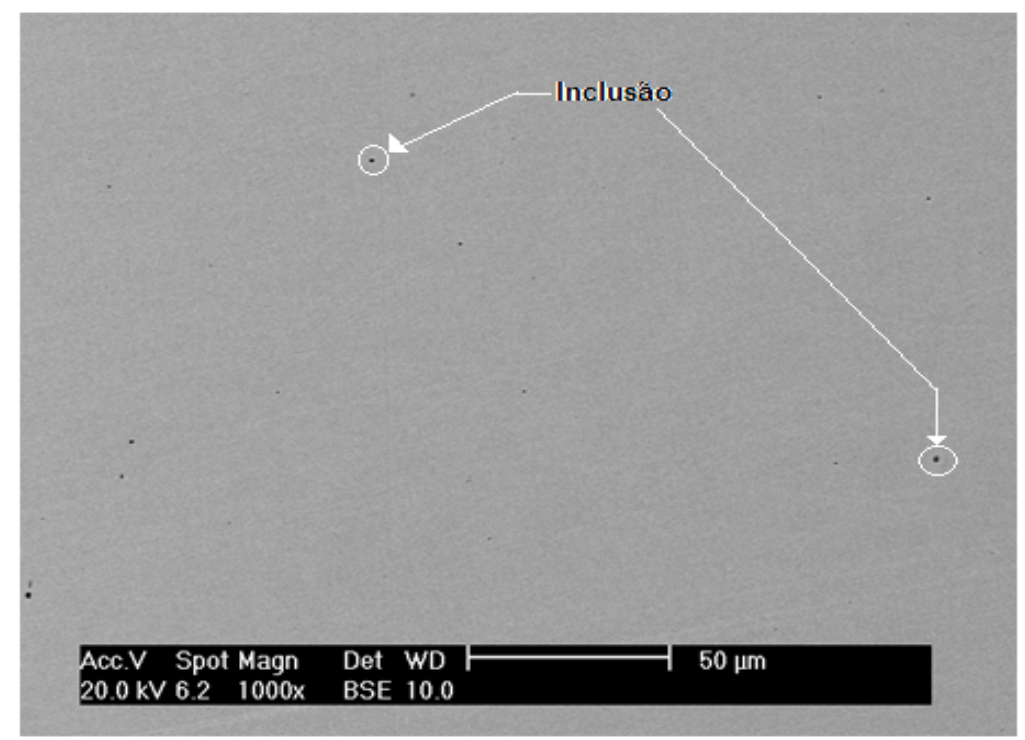

Figura 25 - Distribuição das inclusões no aço inoxidável austenítico 298. Polimento com pasta de diamante $1 \mu \mathrm{m}$. Imagem de elétrons retroespalhados (BSE) com um aumento de 1000x. 
Na Figura 26 são mostradas inclusões com formatos alongados (ponto 2), irregulares (ponto 1) e outras de menores tamanhos com formatos globulares. Para caracterizar os tipos de inclusões, foram determinadas as composições químicas através de análises por EDS.

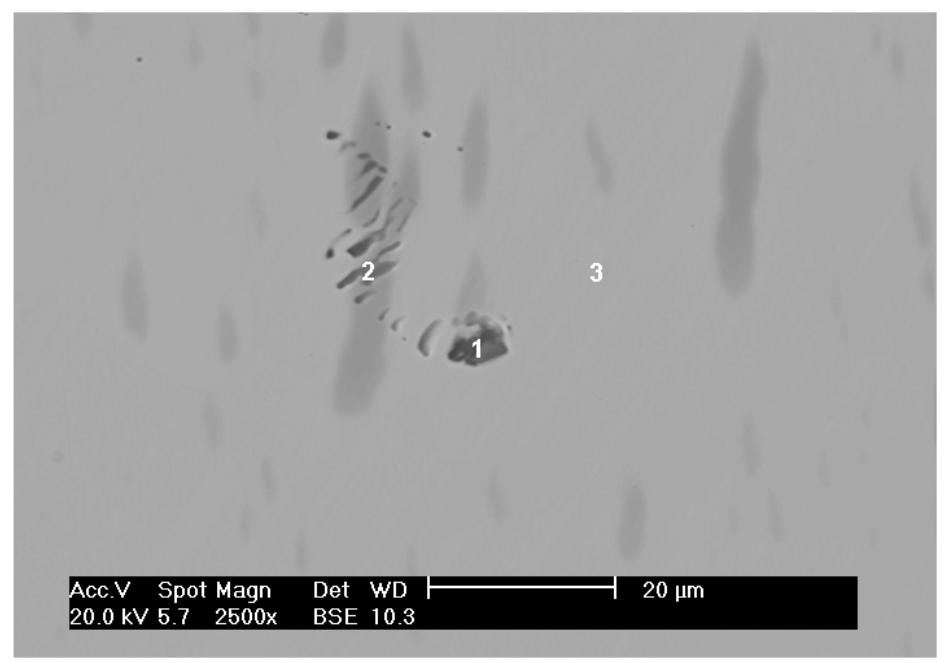

Figura 26 - Imagem de elétrons retroespalhados da superfície de aço 298 polida até diamante $1 \mu \mathrm{m}$. Observam-se inclusões com formatos alongados (2) e arredondados (1); o ponto (3) representa a matriz. Aumento de 2500x.

O resultado da caracterização das inclusões exibidas na Figura 26 é apresentado na Figura 27. No ponto 1 (Figura 27(a)), a análise por EDS mostra uma inclusão complexa contendo predominantemente Al e, em menor teor, o $\mathrm{Cr}$, evidenciando que se trata de óxidos de Al,Cr. O ponto 2 (Figura 27(b)) exibe uma inclusão complexa rica em $\mathrm{Al}, \mathrm{Si}, \mathrm{Mn}$ e $\mathrm{Ca}$. Cabe salientar que os elementos ( $\mathrm{Al}$, Si e $\mathrm{Ca}$ ) que estão presentes nesta inclusão são adicionados na aciaria para desoxidação do metal líquido, devido à forte reatividade destes elementos com o oxigênio. Já no ponto 3 (Figura 27(c)) pode-se observar os teores característicos da matriz do aço 298, que são: $\mathrm{Fe}, \mathrm{Cr}$, $\mathrm{Ni}$ e $\mathrm{Mn}$. 


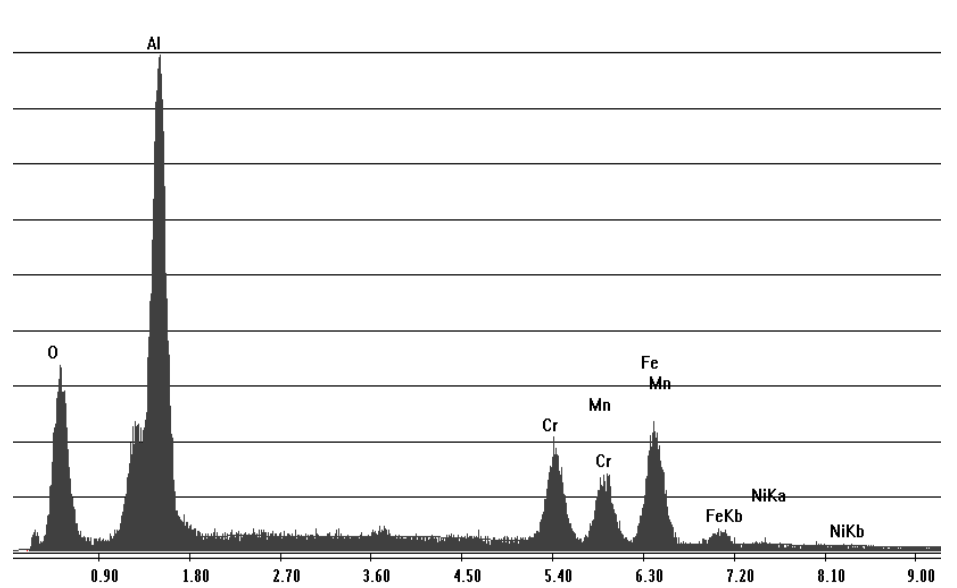

(a)

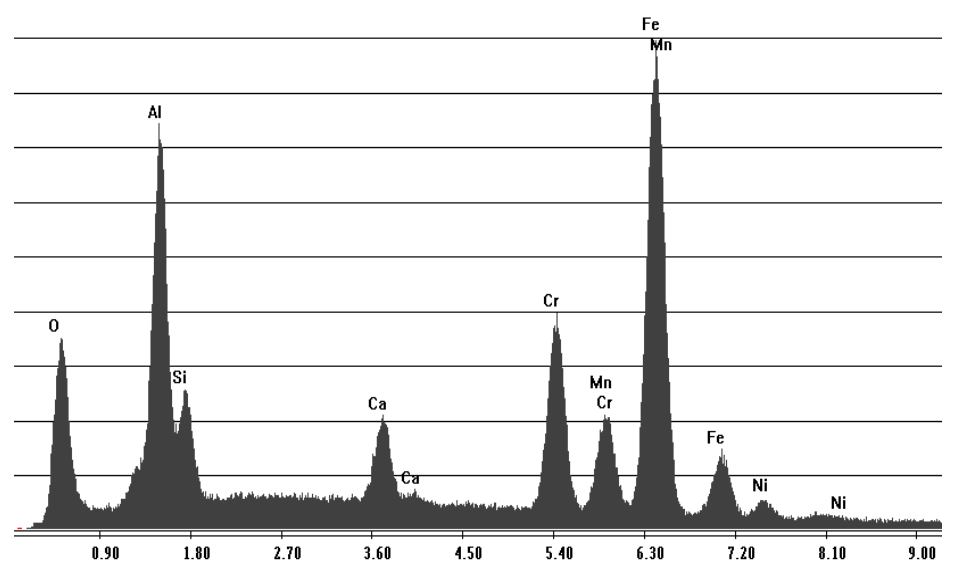

(b)

3

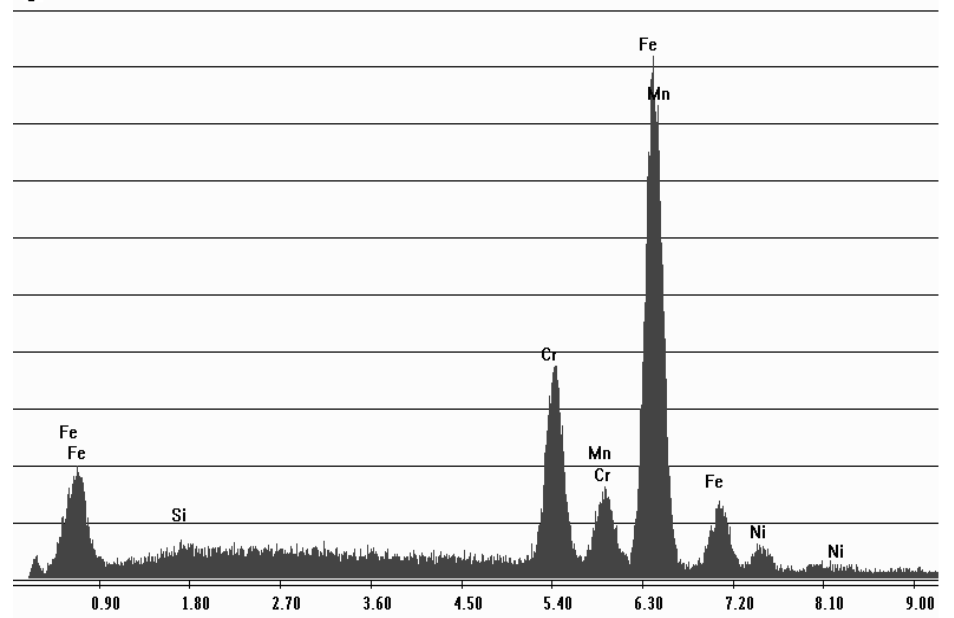

(c)

Figura 27 - Espectros das analises por EDS. (a) ponto 1: inclusão de Al-Cr-Mn-O, (b) ponto 2: inclusão de Al-Si-Mn-Ca-O e (c) ponto 3: matriz. 
Outra inclusão com formato alongado é mostrada na Figura 28. Pode-se perceber a presença de outras inclusões menores com formato globular. Foram realizadas análises por EDS tanto na inclusão quanto na matriz, visando registrar a diferença na composição química destas duas regiões.

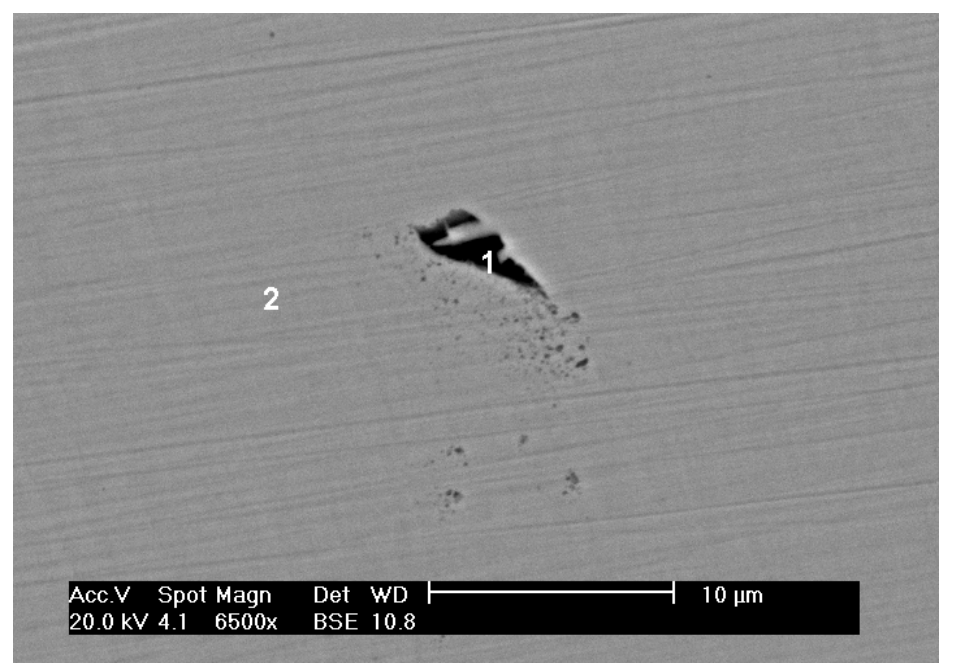

Figura 28 - Imagem de elétrons retroespalhados da superfície de aço 298 polida até diamante $1 \mu \mathrm{m}$. Observa-se uma inclusão com formato alongado. Análise por EDS (a) inclusão (b) matriz. Aumento de 6500x.

O resultado da análise por EDS é mostrado na Figura 29, através do qual é possível observar que se trata de uma inclusão de silício (Si-O).

1

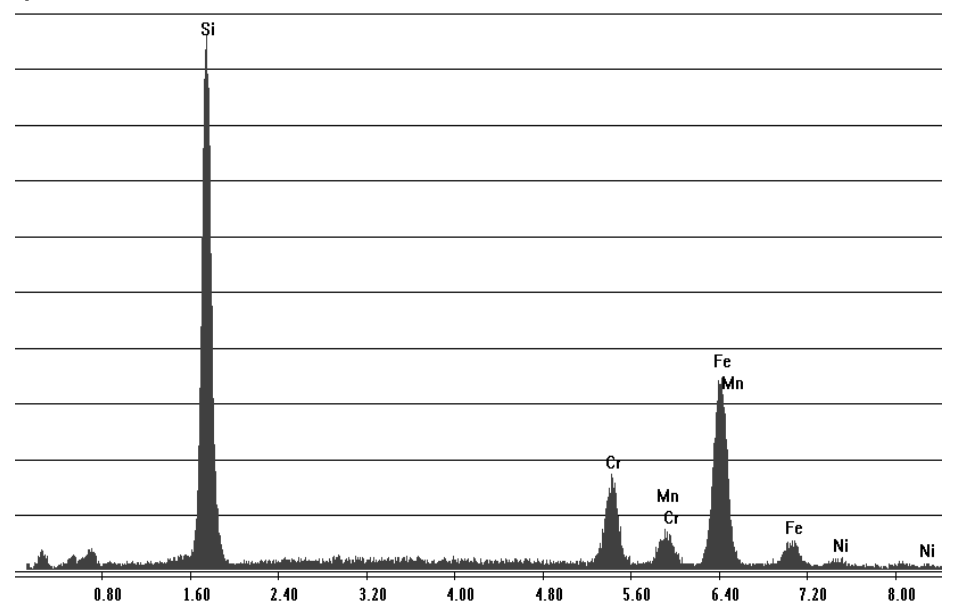

(a) 


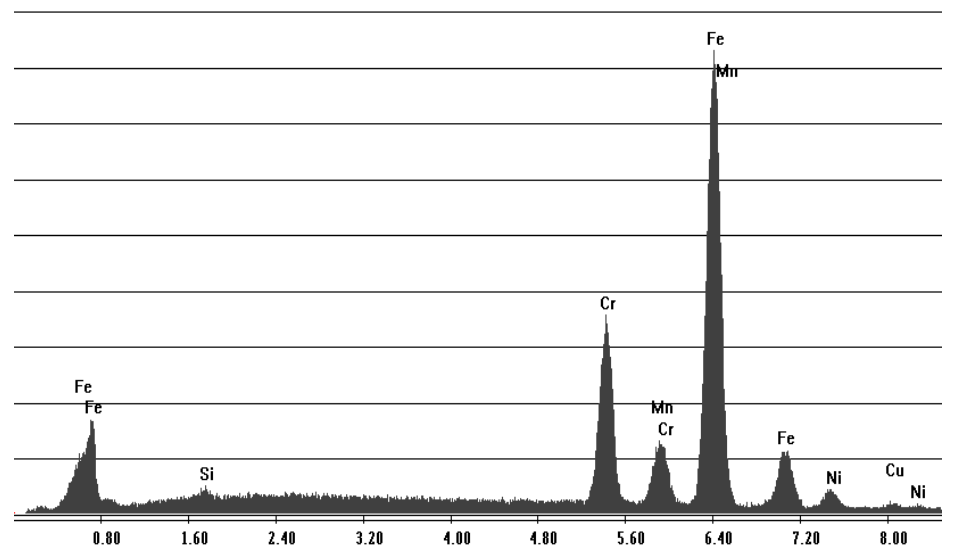

(b)

Figura 29 - Espectros das analises por EDS. (a) inclusão predominantemente de Si-O; os teores de $\mathrm{Fe}-\mathrm{Cr}-\mathrm{Ni}-\mathrm{Mn}$ são provenientes da matriz, dado o pequeno tamanho da região analisada e (b) matriz.

Outra inclusão aproximadamente globular é mostrada na Figura 30, a qual exibe um tamanho menor do que $1 \mu \mathrm{m}$. A respectiva análise por EDS está mostrada na Figura 31. O resultado mostra que esta inclusão contém elevados teores de $\mathrm{S}, \mathrm{Mn}$ e Si, evidenciando que se trata de uma inclusão composta de sulfeto de Mn e óxido de Si. Nota-se que os picos identificados como: $\mathrm{Cr}$ e $\mathrm{Cr}$, $\mathrm{Mn}$ apresentam a mesma altura; isso evidencia que o pico $\mathrm{Cr}$, $\mathrm{Mn}$ é a representação da presença de $\mathrm{Mn}$, uma vez que se sabe que o pico de $\mathrm{Cr}$ desta posição é menor do que o pico de $\mathrm{Cr}$ anterior. Além de ter neste material o S como elemento residual na sua composição química, o qual é inerente do processo de produção, existe também um alto teor de Mn por causa da substituição do $\mathrm{Ni}$. De fato, a possibilidade de se formar sulfeto de $\mathrm{Mn}$ no material é alta, o que prejudica a resistência à corrosão por pite(1),(2),(3), já que este tipo de inclusão é muito suscetível à dissolução durante o processo de corrosão. 


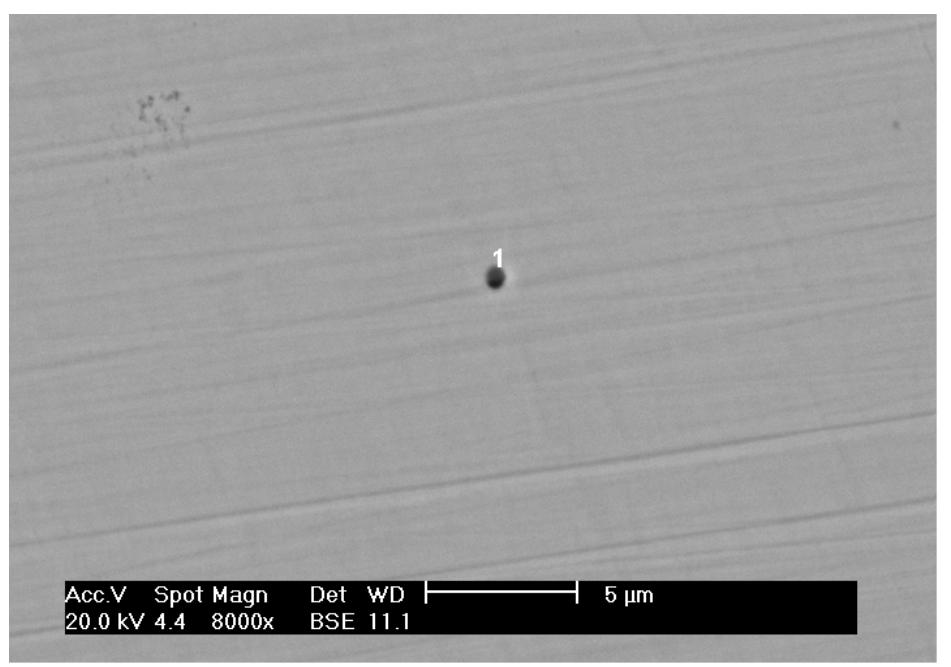

Figura 30 - Imagem de elétrons retroespalhados da superfície de aço 298 polida até diamante $1 \mu \mathrm{m}$. Observa-se uma inclusão com formato globular. Análise por EDS (a) inclusão (b) matriz. Aumento de 8000x.

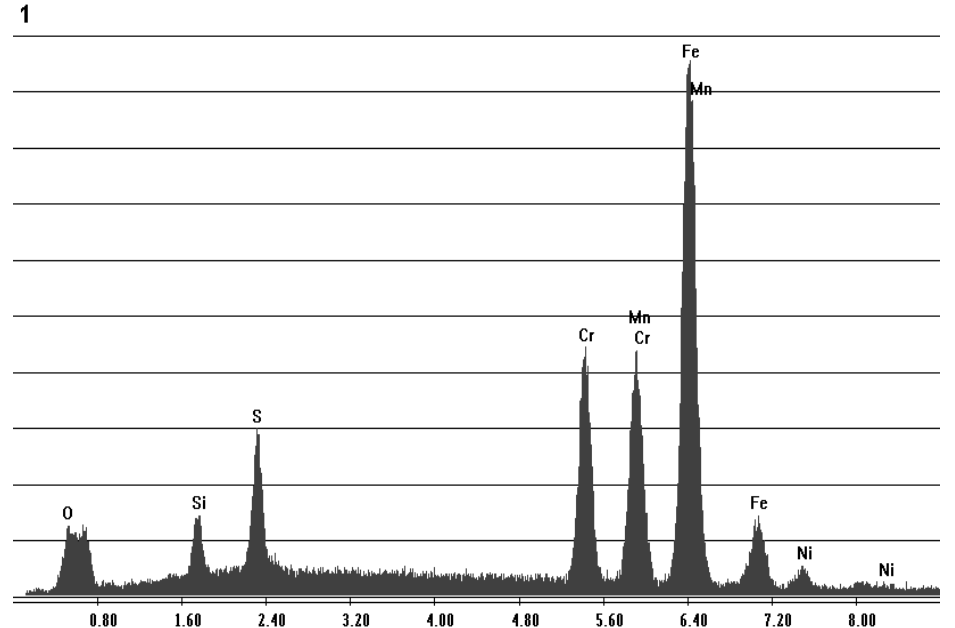

Figura 31 - Espectros das analises por EDS. (a) inclusão predominantemente de MnS e Si-O; os teores de $\mathrm{Fe}-\mathrm{Cr}-\mathrm{Ni}-\mathrm{Mn}$ são provenientes da matriz, dado o pequeno tamanho da região analisada e (b) matriz.

Na micrografia (Figura 32) se observa uma inclusão com um formato alongado (irregular), e outra de menor tamanho com um formato globular. $O$ resultado da análise por EDS é mostrado na Figura 33, através do qual se pode observar que esta inclusão contém altos teores de enxofre e manganês, indicando que se trata de um sulfeto de $\mathrm{Mn}(\mathrm{MnS})$. Os picos de $\mathrm{Fe}, \mathrm{Ni}, \mathrm{Cr}$ e $\mathrm{Cu}$, 
correspondem à composição química da matriz; como no caso da Figura 33, aqui também o pico Cr,Mn representa a presença de Mn na inclusão.

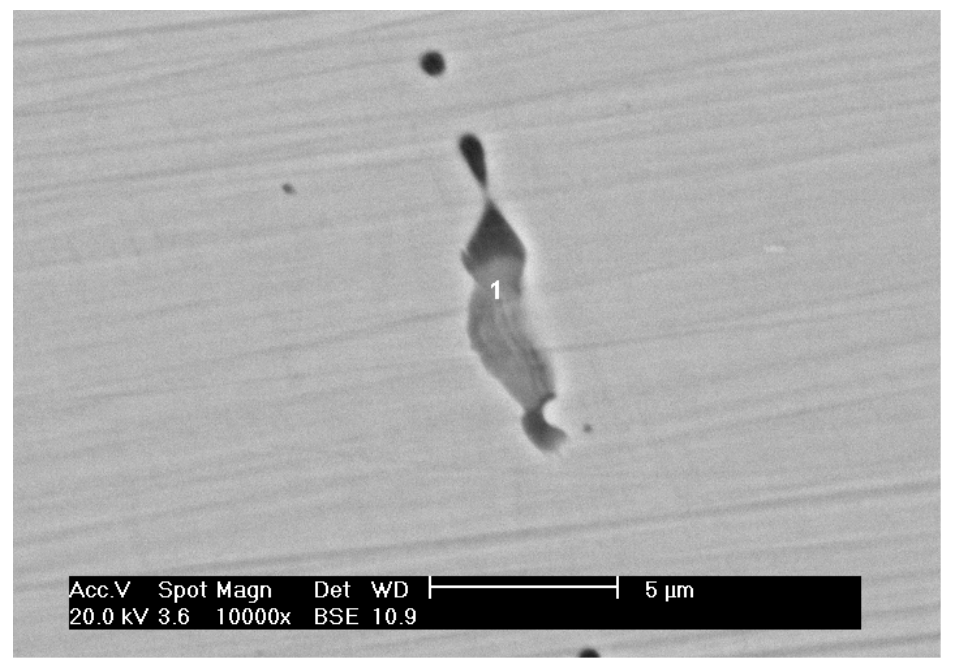

Figura 32 - Imagem de elétrons retroespalhados da superfície de aço 298 polida até diamante $1 \mu \mathrm{m}$. Nota-se uma inclusão com formato alongado. Análise por EDS inclusão . Aumento 10000x.

1

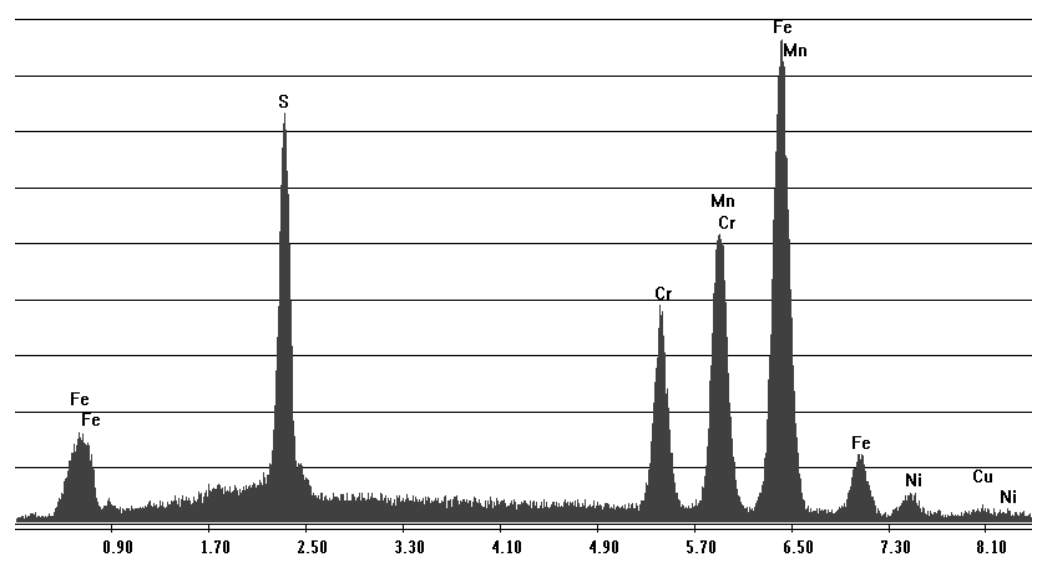

Figura 33 - Espectros das analises por EDS na inclusão. Nota-se teores predominantes de S e $\mathrm{Mn}$, o que indica a existencia de MnS. Cabe salientar que os teores de Fe-Cr-Ni são provenientes da matriz. 
$\mathrm{Na}$ micrografia da Figura 34 é mostrada a microestrutura do aço inoxidável 298 que é constituída de grãos de austenita recristalizados. Também são observadas maclas de recozimento, características dos materiais que têm baixa energia de falha de empilhamento.

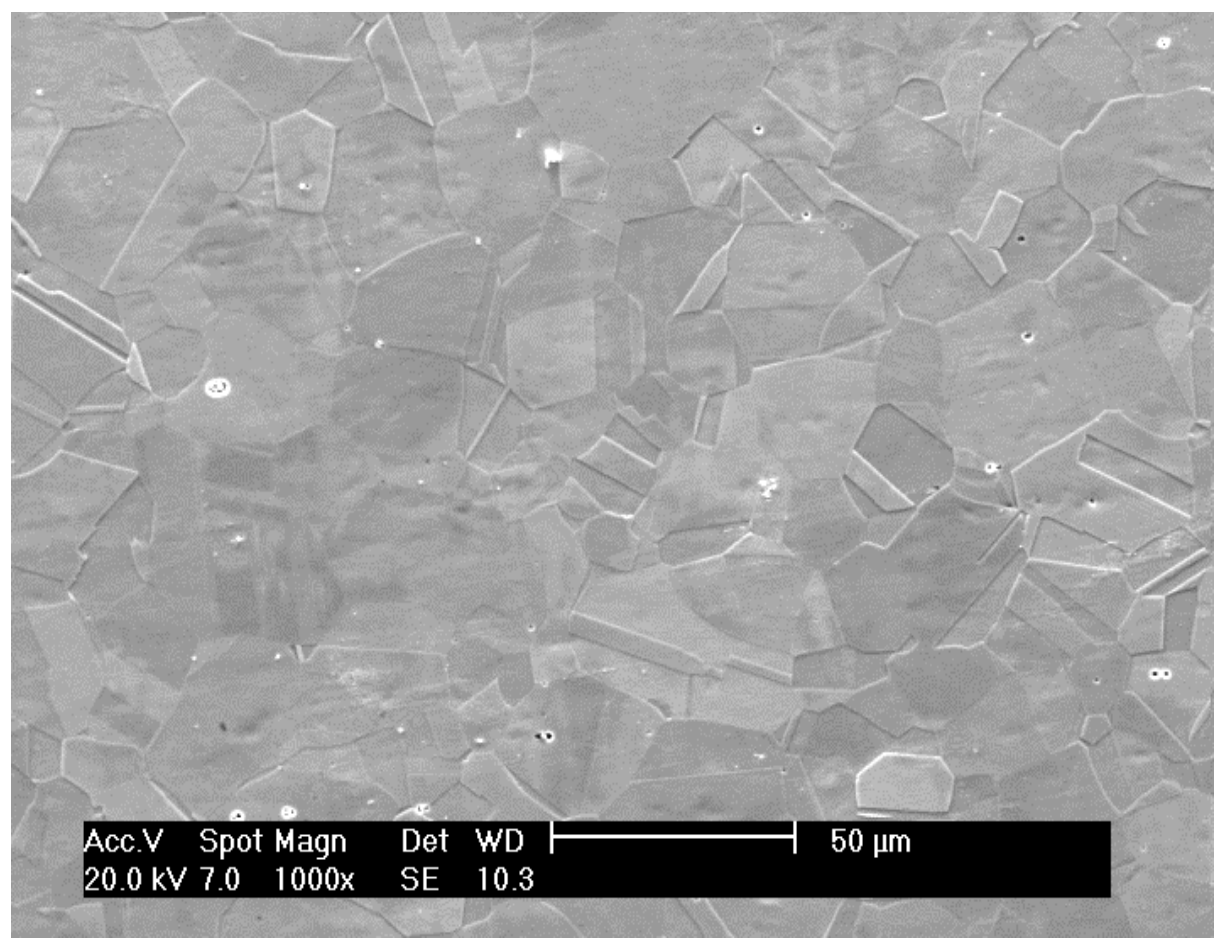

Figura 34 - Microestrutura do aço inoxidável austenítico 298. Polimento e ataque eletrolítico com reagente ácido perclórico $5 \%$. Nota-se a matriz constituída de grãos recristalizados de austenita e a presença de maclas. Aumento $1000 x$

\subsubsection{AÇO 304}

A Figura 35 exibe de forma geral a distribuição das inclusões encontradas na superfície do aço 304. 


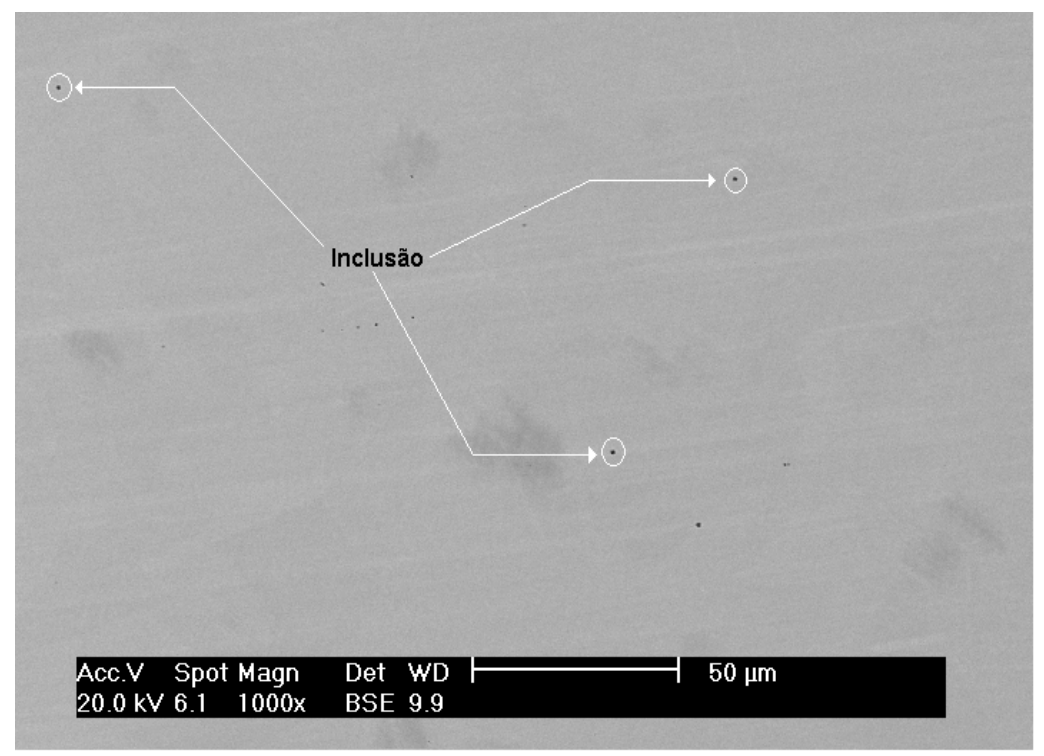

Figura 35 - Distribuição das inclusões no aço inoxidável austenítico 304 . Polimento superficial até $1 \mu \mathrm{m}$. Imagem de elétrons retroespalhados com um aumento de 1000x.

A Figura 36 apresenta uma inclusão irregular com formato alongado e outras de menor tamanho com formato globular.

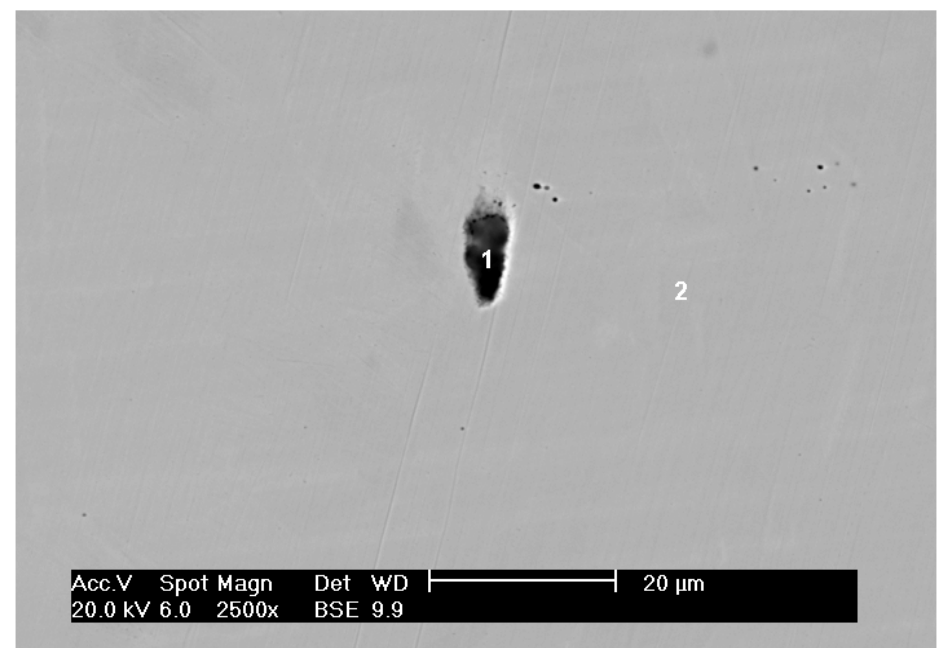

Figura 36 - Aspecto de inclusão encontrada no aço 304 após polimento até $1 \mu \mathrm{m}$. Nota-se a presença de inclusão alongada e outras na forma globular, bem menores. Imagem de elétrons retroespalhados. Aumento de 2500x. 
Os resultados das análises por EDS são mostrados na Figura 37, através dos quais se coloca em evidencia que se trata de uma inclusão de óxido de Al.

1

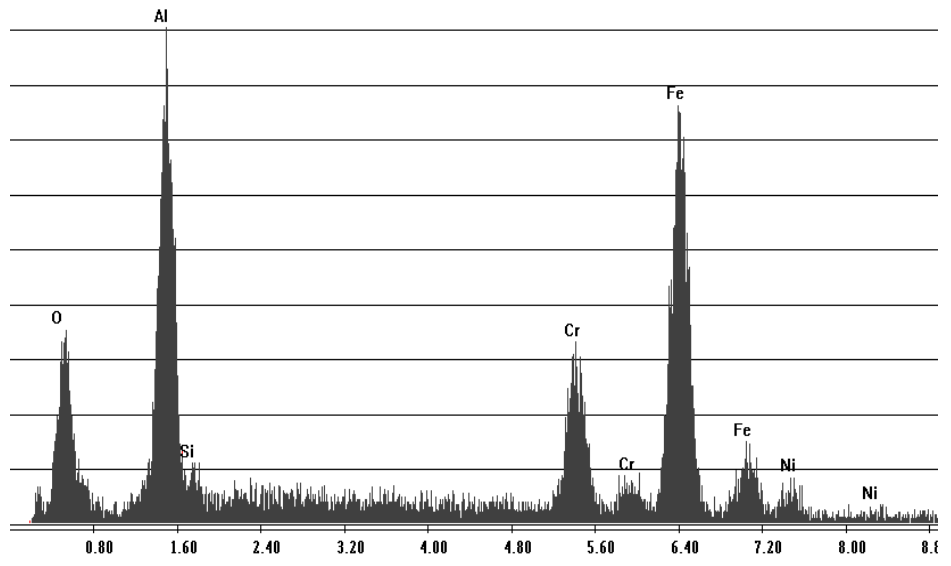

(a)

2

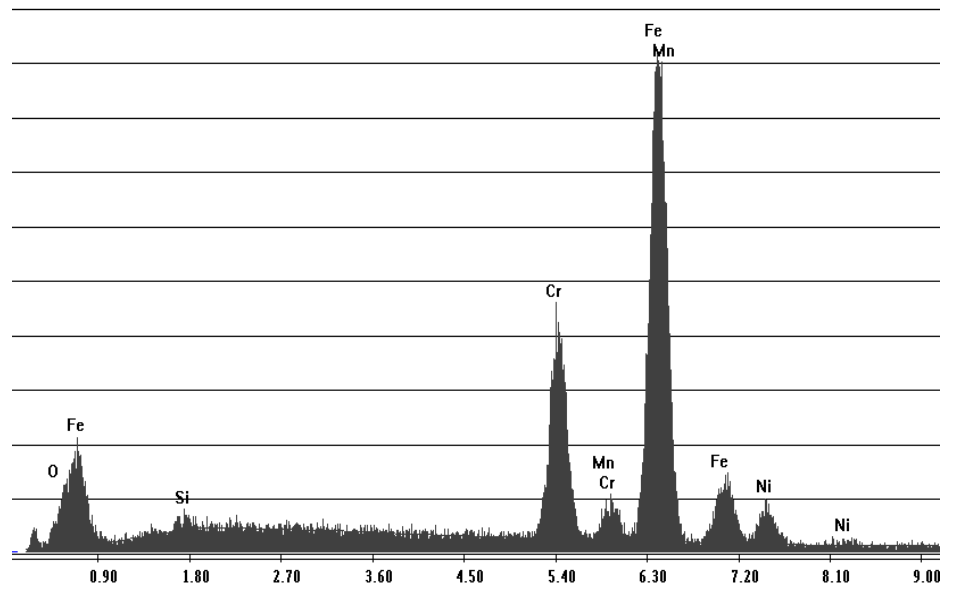

(b)

Figura 37 - Espectros das analises por EDS na inclusão não metálica (ponto 1) e na matriz (ponto 2). Nota-se que a inclusão é constituída de óxido de alumínio e na matriz são encontrados os elementos: Fe-Cr-Ni-Mn.

$\mathrm{Na}$ micrografia da Figura 38 são apresentadas inclusões alongadas e outras sem formatos bem definidos. 


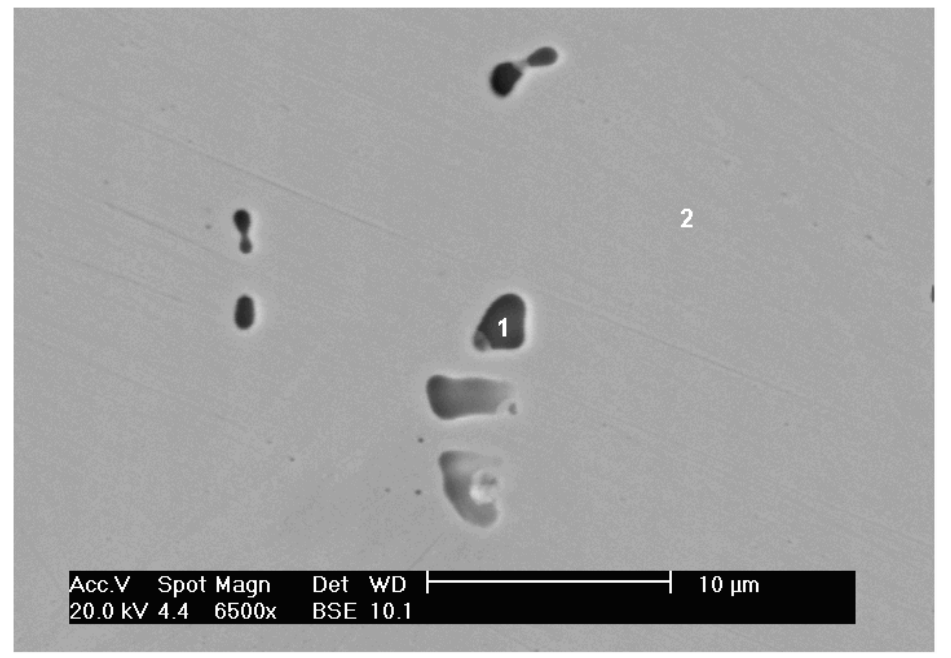

Figura 38 - Aspecto das inclusões encontradas no aço 304 após polimento até $1 \mu \mathrm{m}$. Nota-se a presença de inclusões alongadas e outras sem um formato definido. Imagem de elétrons retroespalhados. Aumento de 6500x.

Os resultados das análises por EDS realizadas tanto na inclusão quanto na matriz são mostrados nas Figura 39(a) e (b). Observa-se que a inclusão é, provavelmente, constituída por óxido de $\mathrm{Ca}, \mathrm{Si}, \mathrm{Mg}$ e Al.

1

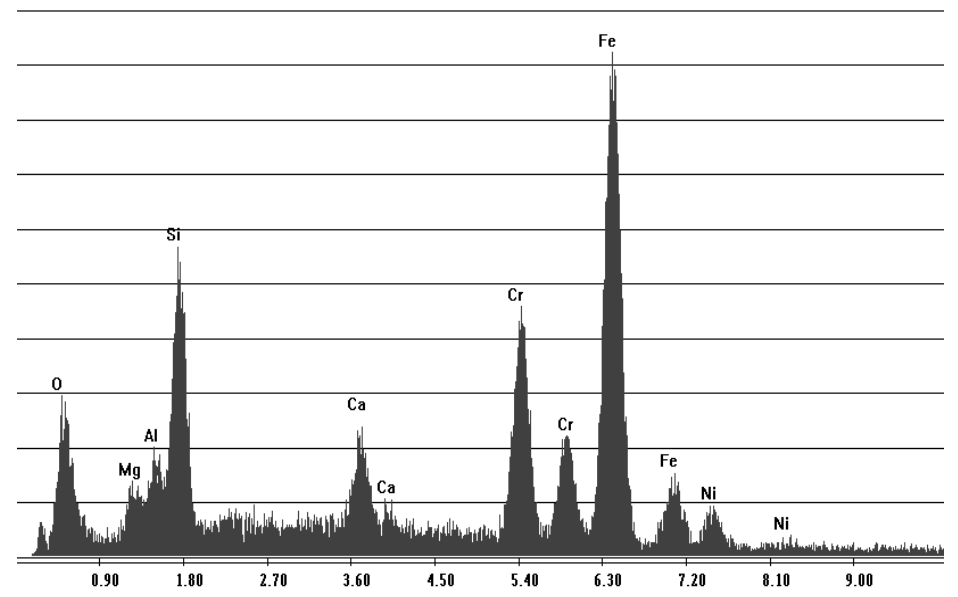

(a) 
2

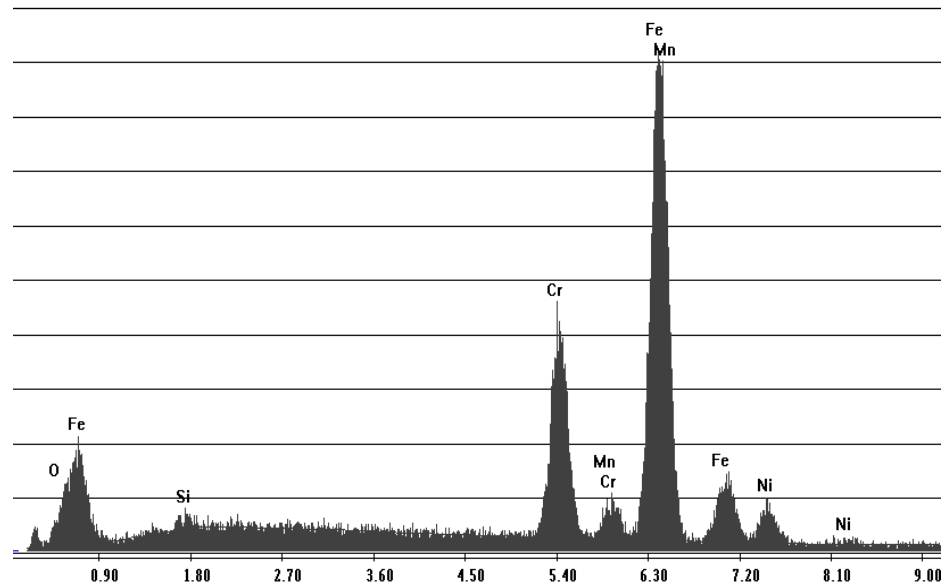

(b)

Figura 39 - Espectros das analises por EDS na inclusão não metálica presente na superfície do aço 304. (a) ponto 1: inclusão e (b) ponto 2: matriz.

A Figura 40 exibe duas inclusões encontradas na superfície do aço 304.

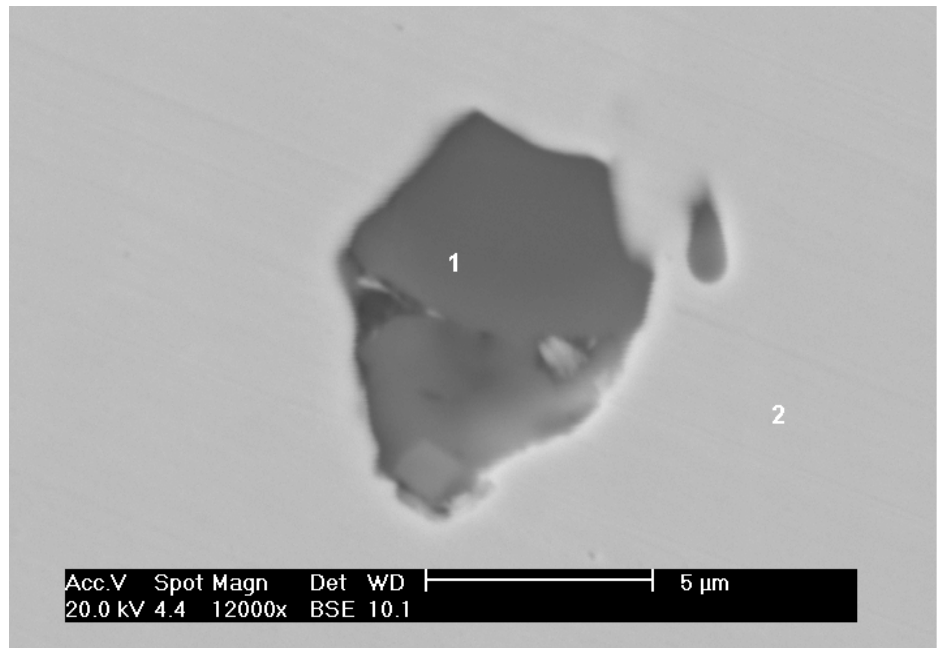

Figura 40 - Aspecto da inclusão encontrada no aço 304 após polimento até $1 \mu \mathrm{m}$. Imagem de elétrons retroespalhados. Aumento de 12000x.

Os resultados das análises por EDS são mostrados na Figura 41. Nota-se que a inclusão contém na sua composição química elevados teores de $\mathrm{Mg}, \mathrm{Al}$, Mn e oxigênio, e em menor porcentagem o $\mathrm{Ca}$, caracterizando uma inclusão de óxido mista. 
1

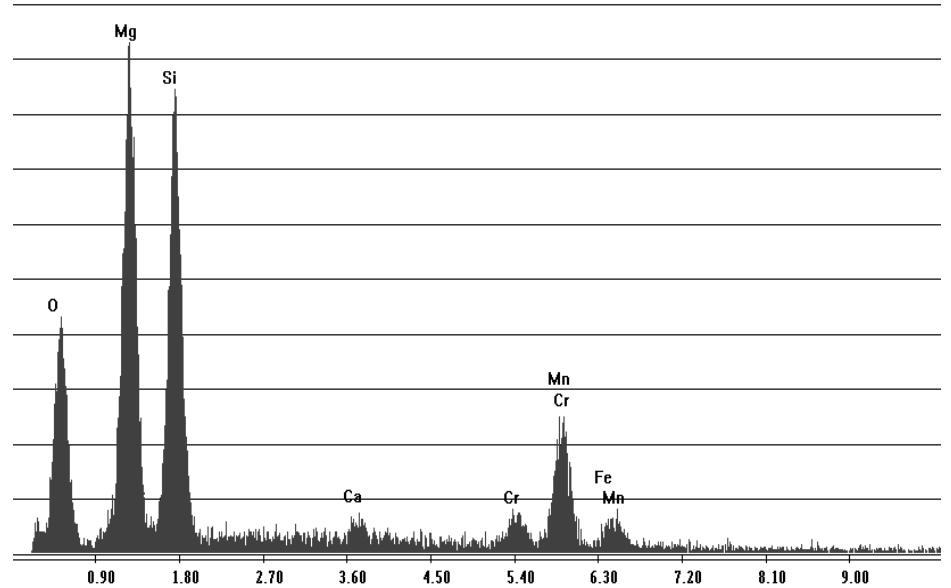

(a)

2

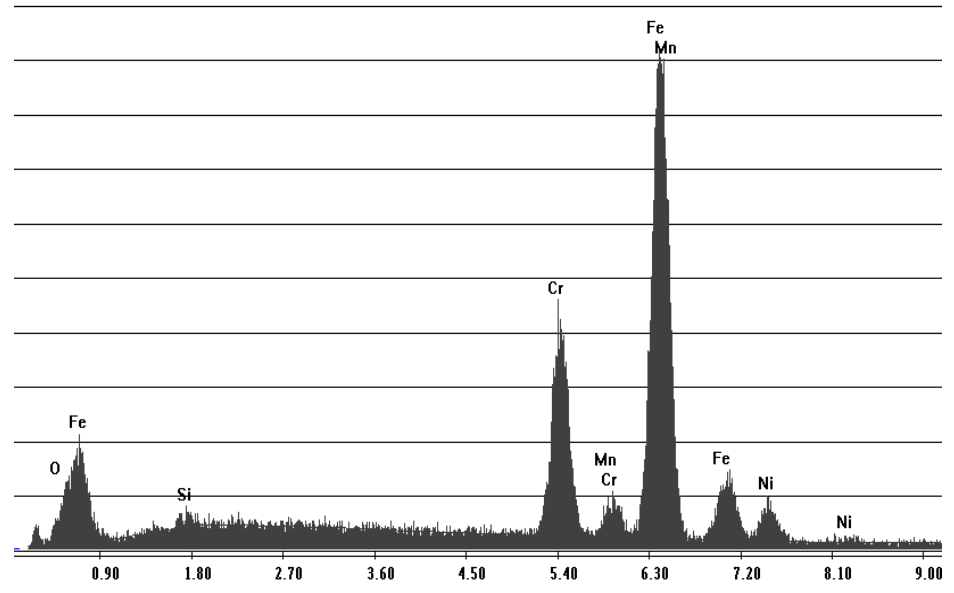

(b)

Figura 41 - Espectros das analises por EDS na inclusão não metálica presente na superfície do aço 304. (a) ponto 1: inclusão e (b) ponto 2: matriz.

$\mathrm{Na}$ micrografia (Figura 42) se observa uma inclusão com um formato alongado. O resultado da análise por EDS é mostrado na Figura 43, através do qual se pode observar que esta inclusão contém altos teores de enxofre e manganês, indicando que se trata de um sulfeto de manganês. Os picos de ferro, níquel, cromo e cobre, correspondem à composição química da matriz. 


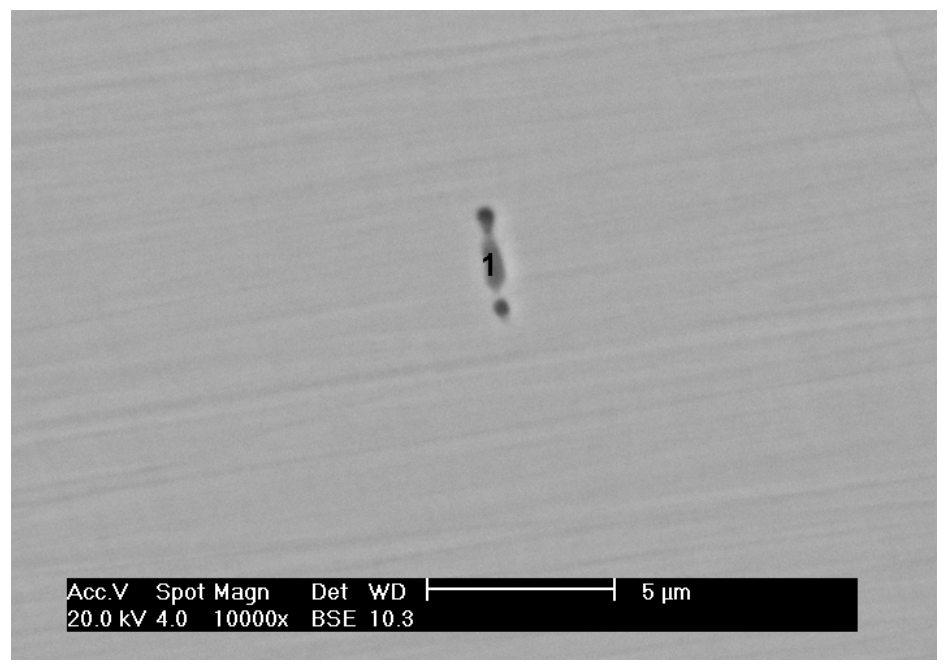

Figura 42 - Imagem de elétrons retroespalhados da superfície de aço 304 polida até diamante $1 \mu \mathrm{m}$. Nota-se uma inclusão com formato alongado. Análise por EDS (a) inclusão . Aumento de 10000x.

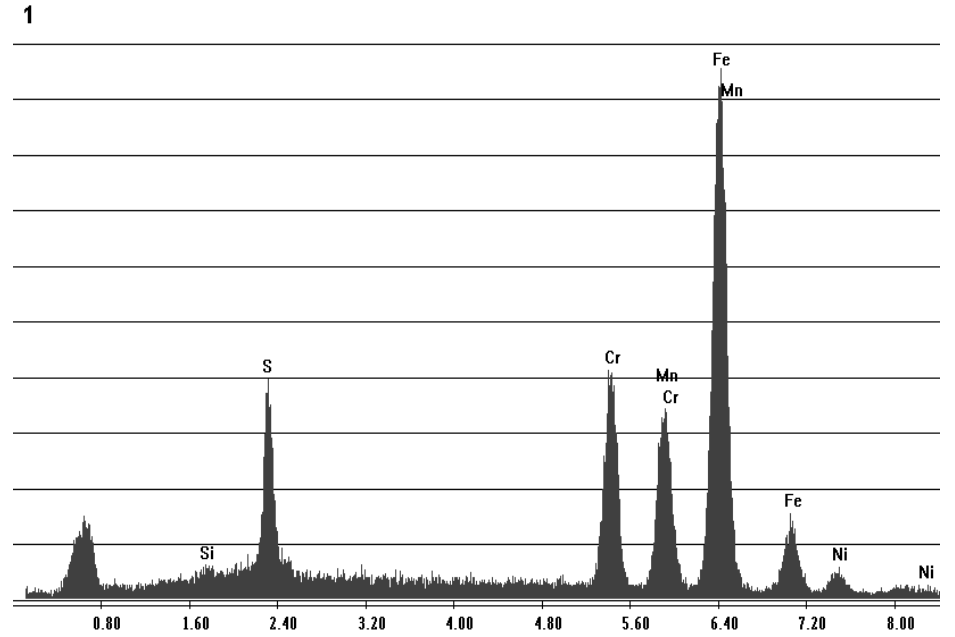

Figura 43 - Espectros das analises por EDS na inclusão. Nota-se teores predominantes de S e $\mathrm{Mn}$, o que indica a existência de MnS. Cabe salientar que os teores de $\mathrm{Fe}-\mathrm{Cr}-\mathrm{Ni}$ são provenientes da matriz.

É apresentada a microestrutura do aço 304 na Figura 44. Esta microestrutura é constituída de grãos recristalizados de austenita, com presença de maclas de recozimento, as quais são características deste tipo de material. 


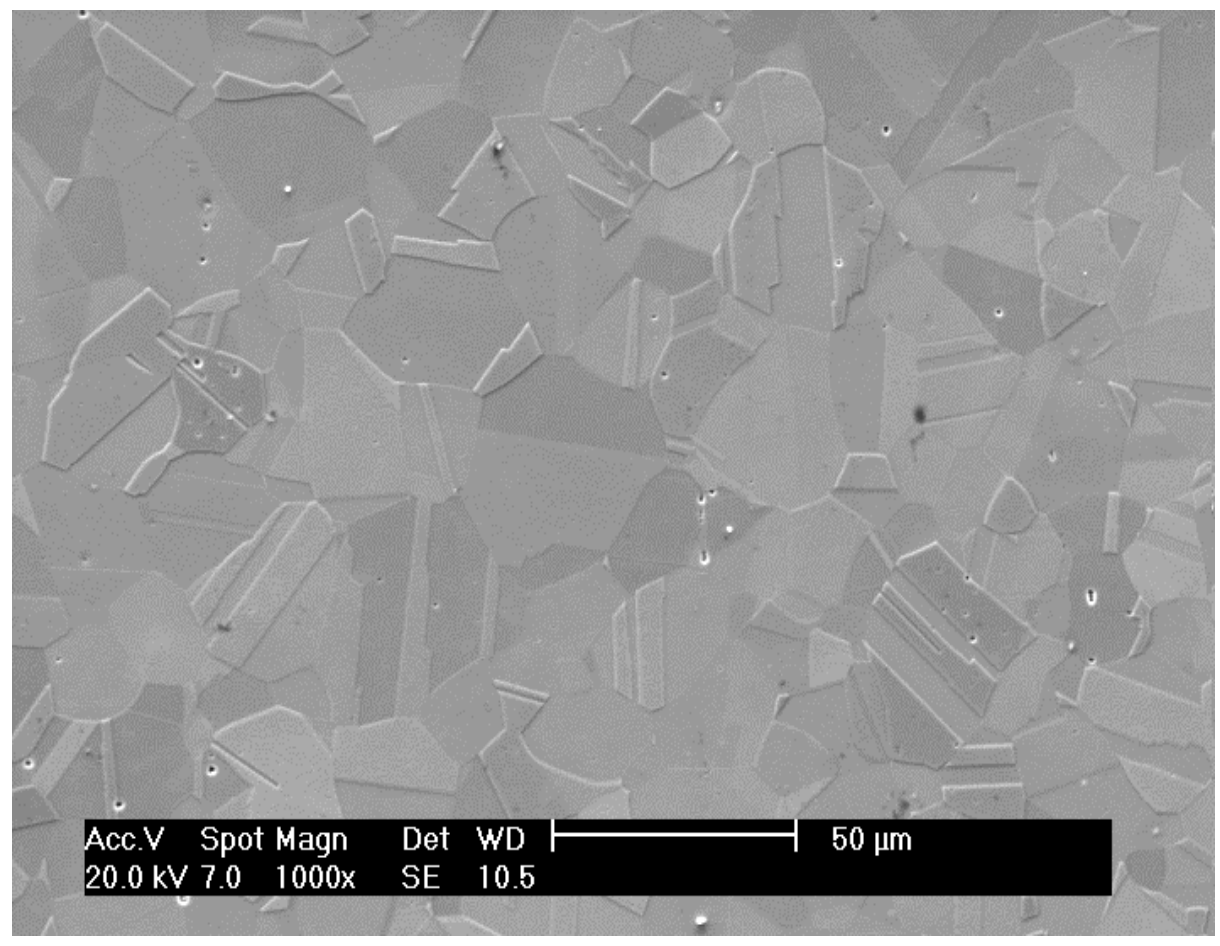

Figura 44 - Microestrutura do aço inoxidável austenítico 304. Nota-se a matriz constituída de grãos recristalizados de austenita e a presença de maclas de recozimento. Imagem de elétrons secundários. Polimento eletrolítico em ácido perclórico $5 \%$ e ataque eletrolítico feito com ácido oxálico $10 \%$. Aumento 1000x.

\subsubsection{AÇO 316L}

A Figura 45 apresenta de forma geral a distribuição das inclusões formadas na superfície do material. Nesta micrografia (Figura 45) pode-se observar a presença de uma grande quantidade de inclusões com formato globular. Comparativamente aos materiais anteriores: 298 e 304, o aço 316L caracterizou-se por apresentar maior densidade de inclusões. 


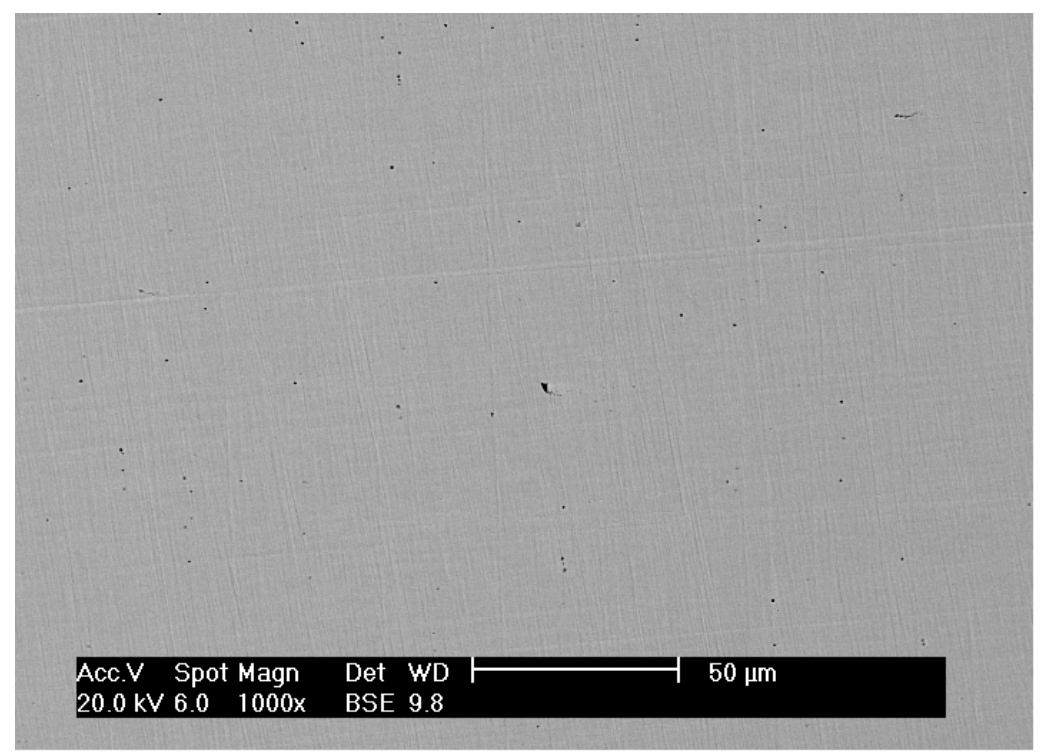

Figura 45 - Distribuição das inclusões no aço inoxidável austenítico 316L. Polimento superficial até $1 \mu \mathrm{m}$. Imagem de elétrons retroespalhados com um aumento de 1000x.

A Figura 46 mostra uma inclusão com um formato irregular, no entanto, existem outras inclusões menores com formato globular. Para caracterizar o tipo de inclusão, é necessário encontrar a sua composição química mediante uma análise por EDS.

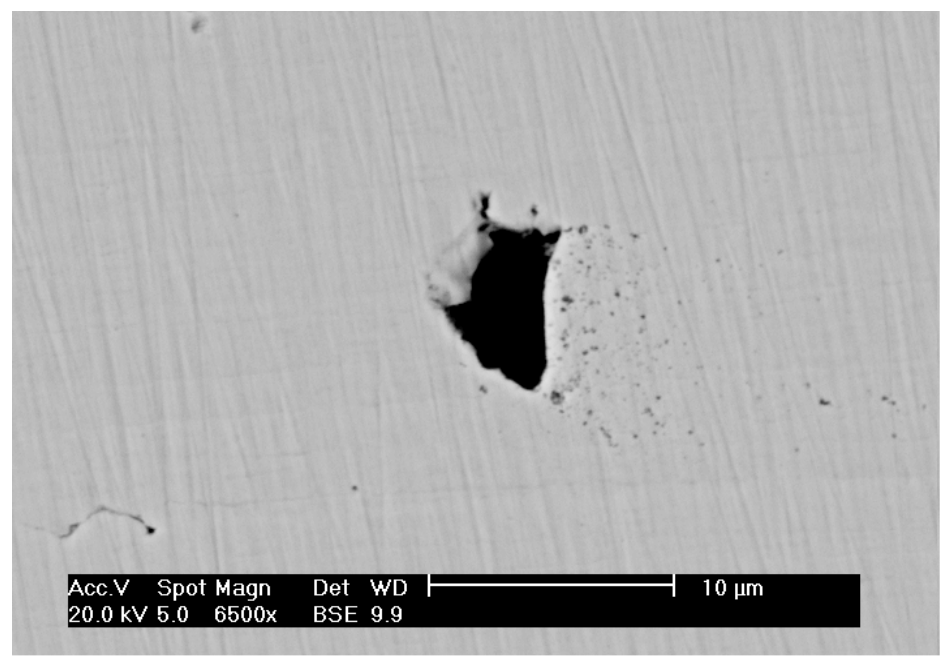

Figura 46 - Aspecto da inclusão encontrada no aço 316L após polimento até $1 \mu \mathrm{m}$. Imagem de elétrons retroespalhados. Aumento de 6500x. Nota-se pequenas inclusões distribuídas aleatoriamente ao redor da inclusão maior. 
O resultado da análise por EDS (Figura 47) mostra uma inclusão rica em Si (óxido de Si). É importante salientar que este material apresentou uma densidade alta deste tipo de inclusões sobre a superfície.

1

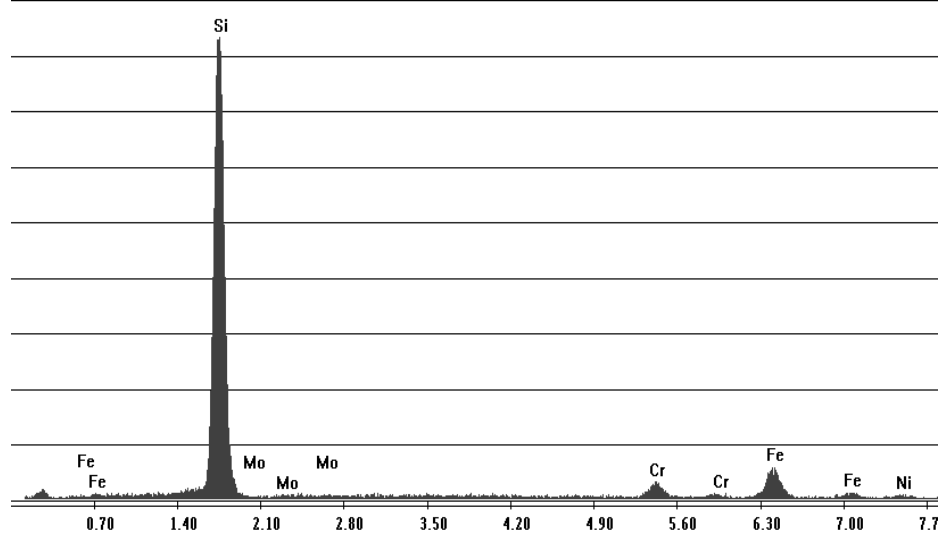

Figura 47 - Espectro de analises por EDS na inclusão não metálica presente na superfície do aço 316L.

A inclusão mostrada na micrografia (Figura 48) além de apresentar um formato circular, apresenta também uma diferença na sua composição química.

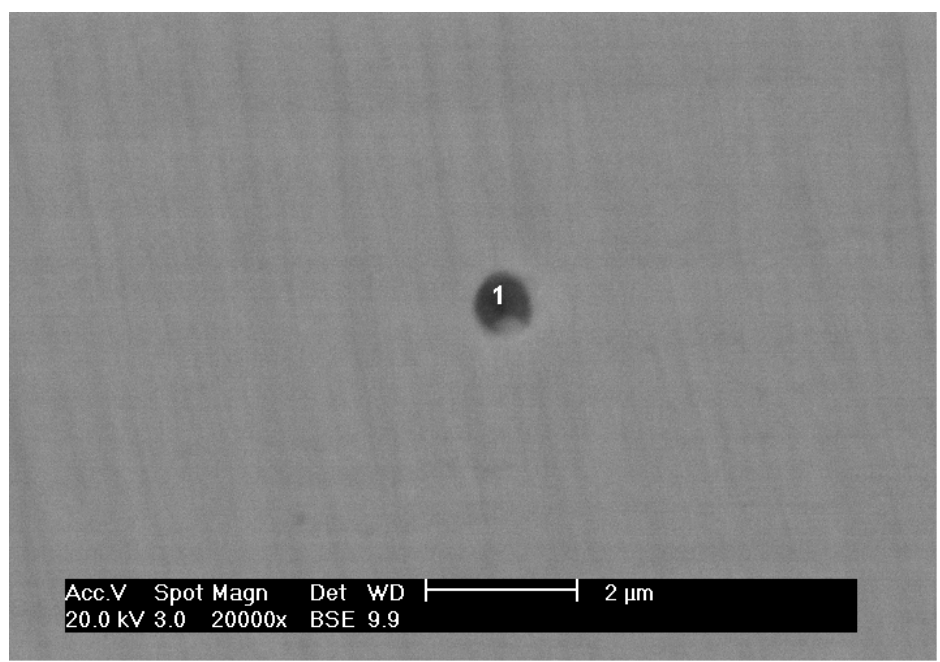

Figura 48 - Aspecto da inclusão encontrada no aço 316L após polimento até $1 \mu \mathrm{m}$. Imagem de elétrons retroespalhados. Aumento de 6500x. Nota-se uma diferença do cor na inclusão, o que indica uma diferença significativa na composição química. 
O resultado da análise por EDS é mostrado na Figura 49, através do qual se pode observar que esta inclusão contém elevados teores de Al, Si e Mn, o que indica que se trata de uma inclusão complexa composta por uma mistura de óxidos de (Si e Al) e um sulfeto de Mn (MnS). Já os elementos $\mathrm{Fe}, \mathrm{Cr}, \mathrm{Ni}$ e Mo correspondem aos teores da matriz.

1

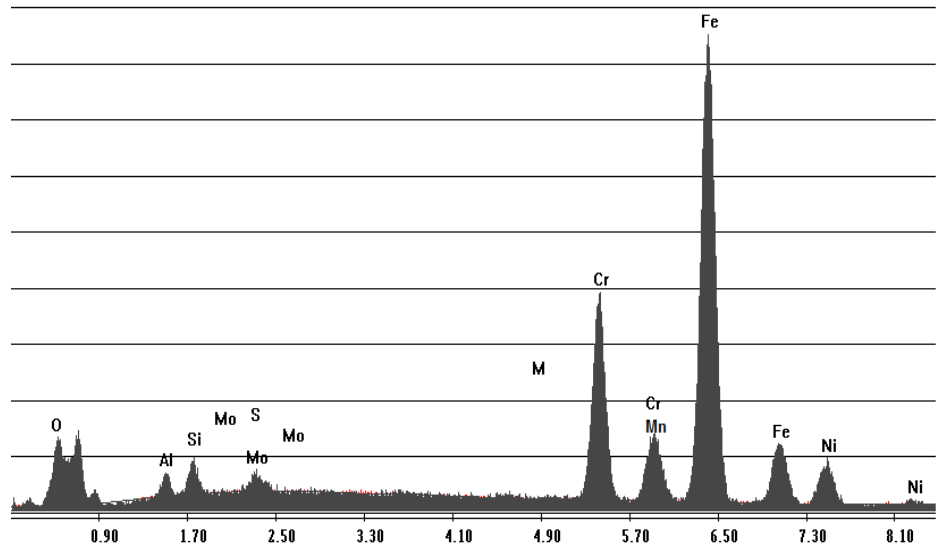

(a)

1

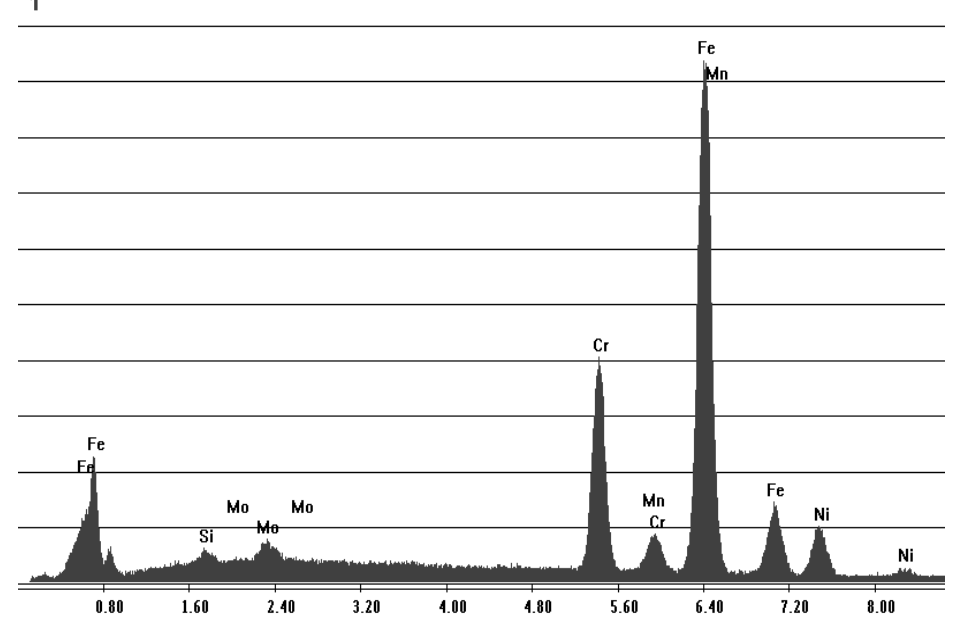

(b)

Figura 49 - Espectro de analises por EDS. (a) Inclusão não metálica (1) e (b) matriz (aço 316L). 
Na Figura 50 se mostra uma inclusão com formato alongado, e outras de menor tamanho com um formato mais circular. Foi realizada uma análise por EDS para determinar a composição química desta inclusão.

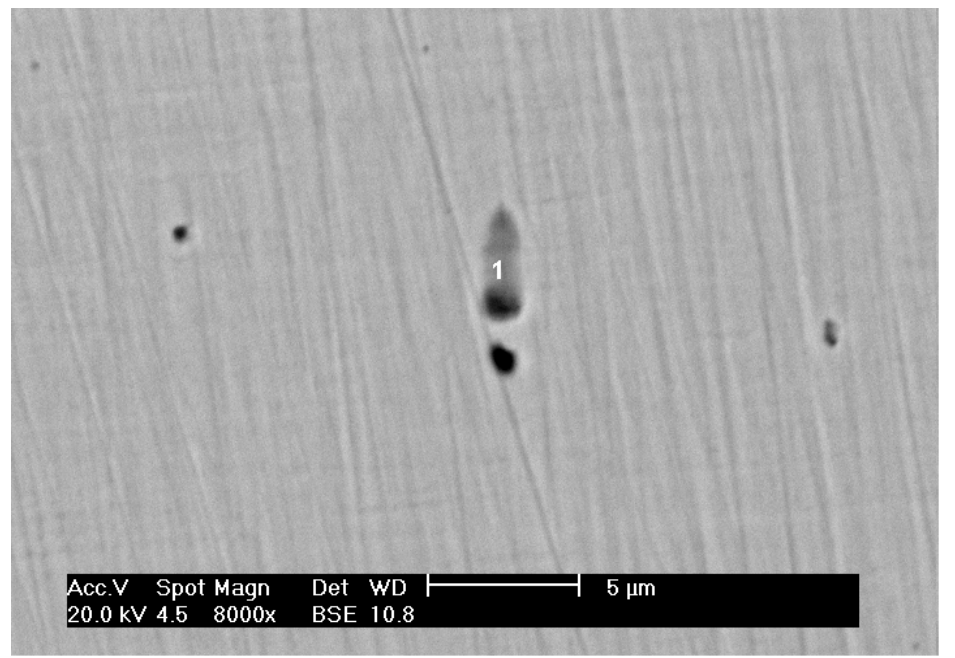

Figura 50 - Aspecto da inclusão (formato alongado) encontrada no aço 316 L após polimento até $1 \mu \mathrm{m}$. Imagem de elétrons retroespalhados. Aumento de 8000x.

O resultado da análise por EDS é mostrado na Figura 51, através do qual se observa que a inclusão contém altos teores de $\mathrm{S}$ e $\mathrm{Mn}$, o que indica que se trata de um sulfeto de manganês (MnS). Cabe salientar que este tipo de inclusão é prejudicial para a resistência à corrosão por pite, já que ela é susceptível à dissolução durante o ensaio de corrosão(63). 


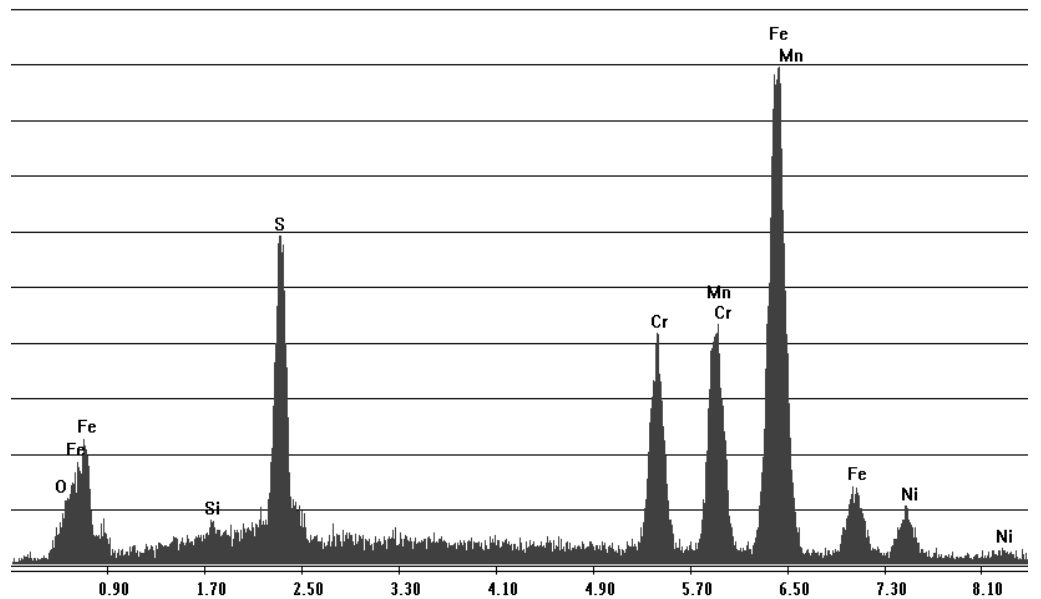

Figura 51 - Espectro de analises por EDS realizada na inclusão. Cabe ressaltar que os picos de $\mathrm{Cr}$, Fe e Ni correspondem aos teores da matriz do aço 316L.

A Figura 52 apresenta o aspecto da microestrutura do aço 316L. Como no caso do aço 304, a microestrutura é composta por grãos recristalizados de austenita, com a presença de maclas de recozimento.

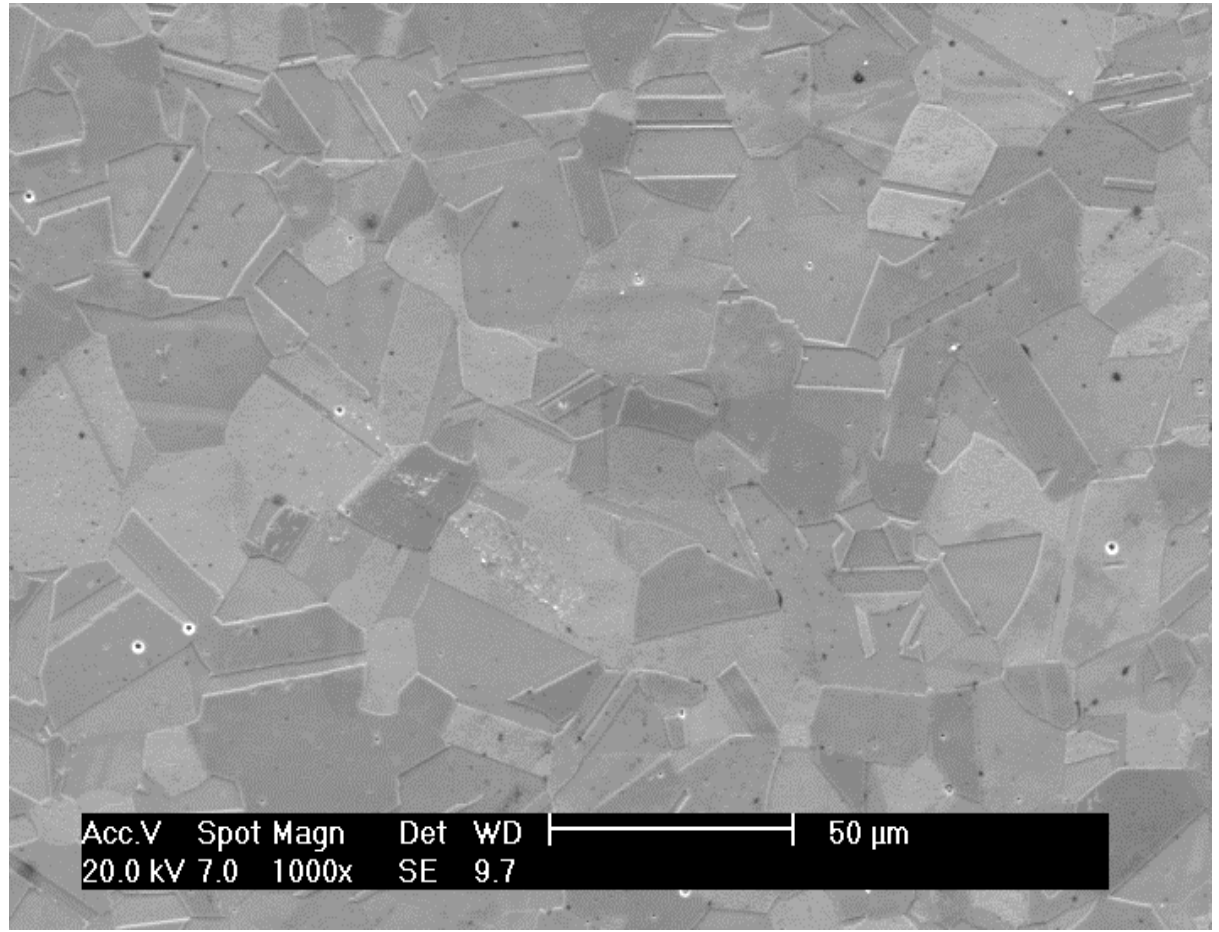

Figura 52 - Microestrutura do aço inoxidável austenítico 316L. Aumento: 1000x. Nota-se a matriz constituída de grãos recristalizados de austenita e a presença de maclas de recozimento. Imagem de elétrons secundários. Ataque eletrolítico com ácido oxálico 10\%. 


\subsubsection{AÇO 430}

A Figura 53 apresenta de forma geral a distribuição das inclusões encontradas na superfície do aço 430. É interessante notar que a maioria das inclusões tem formato circular, no entanto, nota-se a presença de inclusões de com formatos alongados. Como no caso do aço 316L, o aço 430 também apresentou maior densidade de inclusões do que os aços 298 e 304.

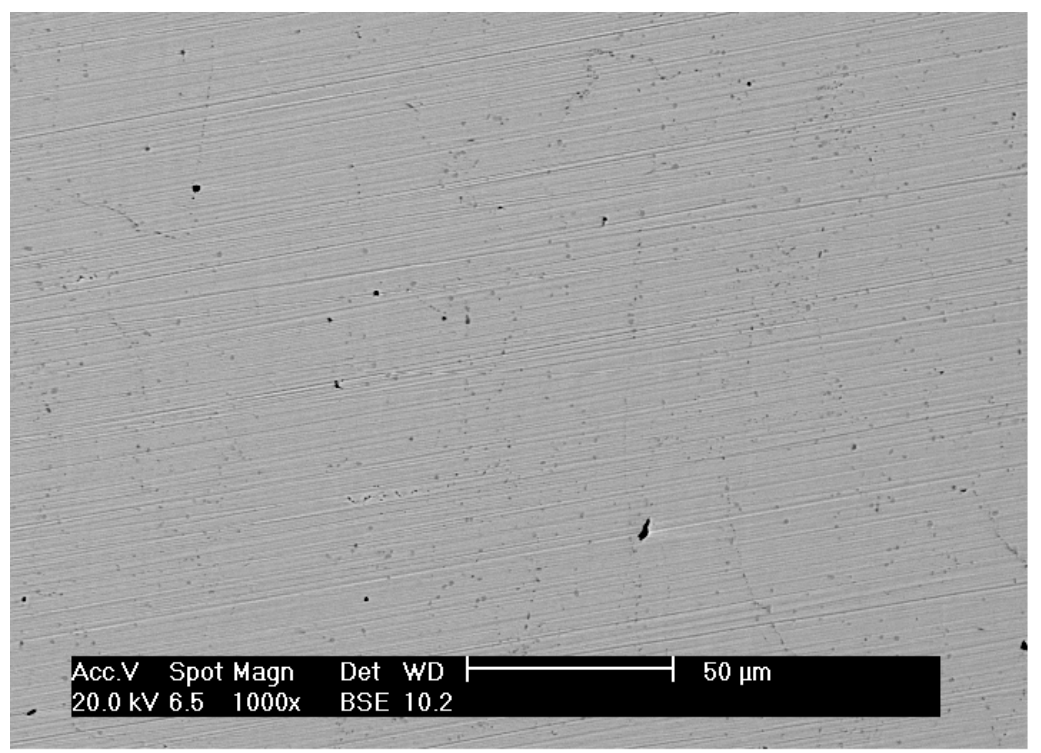

Figura 53 - Distribuição das inclusões no aço inoxidável ferrítico 430. Polimento superficial até $1 \mu \mathrm{m}$. Imagem de elétrons retroespalhados com um aumento de 1000x.

A Figura 54 mostra duas inclusões com aspectos diferentes, uma delas apresenta um formato alongado e a outra exibe uma forma mais circular. Para determinar a composição química destas inclusões foram realizadas análises por EDS. Os resultados estão mostrados nas Figura 55 - (a) e (b), através das quais se observa que estas inclusões estão compostas por Al, indicando-se tratar de óxido Al. 


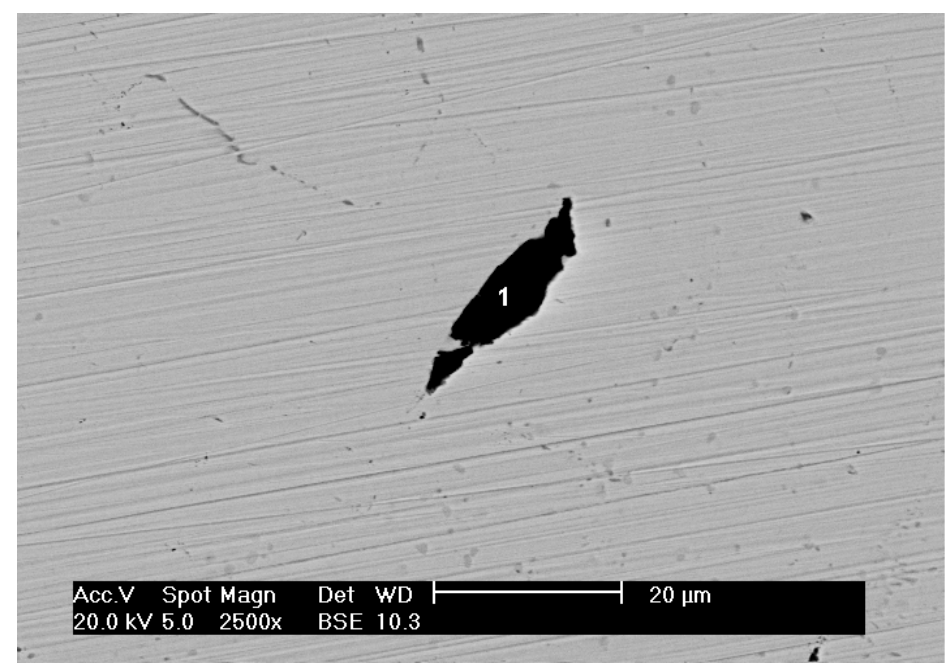

(a)

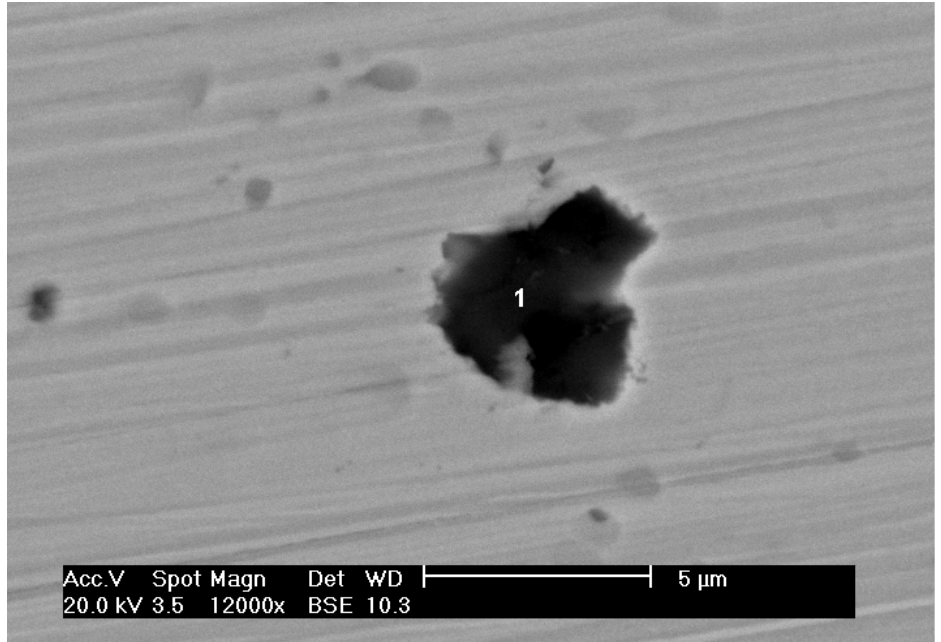

(b)

Figura 54 - Imagem de elétrons retroespalhados. Aspecto de duas inclusões encontradas na superfície do aço $316 \mathrm{~L}$ após polimento até $1 \mu \mathrm{m}$. (a) formato alongado: aumento de 2500 e (b) formato globular: aumento de 12000x. 


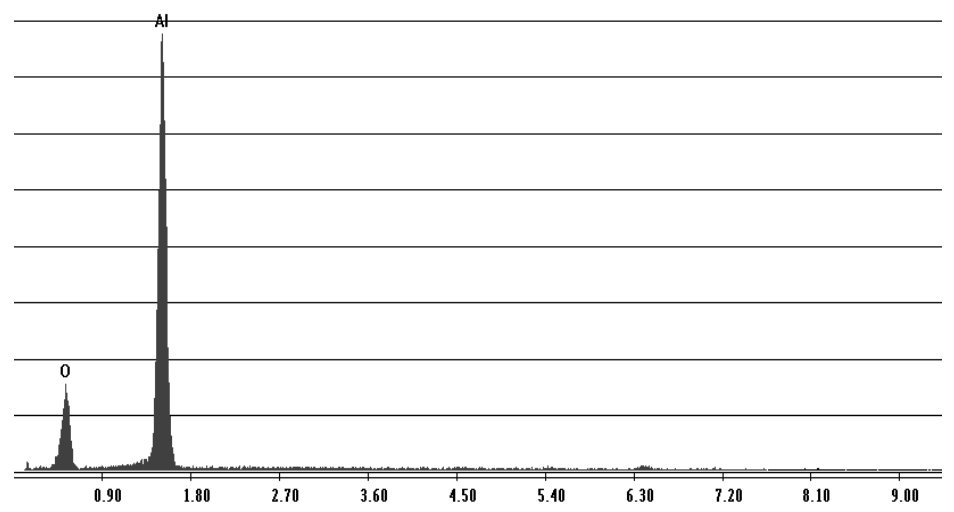

(a)

1

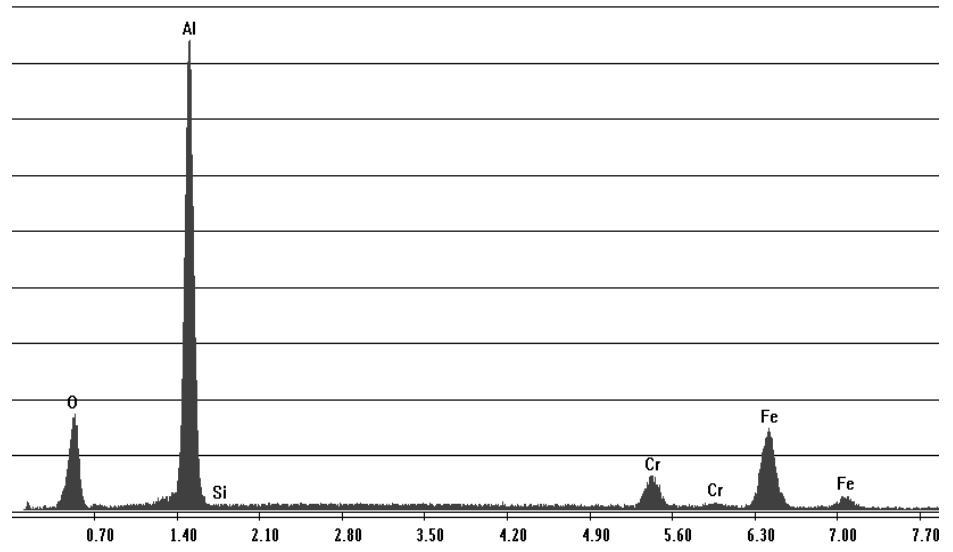

(b)

Figura 55 - Espectro de analises por EDS realizada nas inclusões. Cabe ressaltar que os picos de $\mathrm{Cr}$ e Fe (Figura 55(b)) correspondem aos teores da matriz do aço 316L.

A Figura 56 mostra uma inclusão (cor preta: ponto 1) e outra fase de cor cinza (ponto 2). Os resultados das análises por EDS destas fases estão mostrados na Figura 57. O espectro da inclusão do ponto 1, indica a presença de Al, Si e em menores porcentagens os $\mathrm{S}$ e Ti, o que já é uma evidência de se tratar de inclusão composta por uma mistura de óxido de Al e Si e sulfeto de Ti (TiS). Já o espectro do ponto 2 mostra uma fase rica em Cr. Pela composição química do aço 430, é esperada a precipitação de carbonetos de $\mathrm{Cr}$ (17). De fato, a Figura 62, mostra que a microestrutura desse aço tem grande quantidade de carbonetos de $\mathrm{Cr}$ precipitados. A Figura 62 é o resultado do 
ataque eletrolítico em ácido oxálico, ataque que dissolve as fases ricas em $\mathrm{Cr}$, no presente caso, carbonetos de $\mathrm{Cr}$. As cavidades encontradas na micrografia da Figura 62 são os locais onde antes estavam precipitados os carbonetos de $\mathrm{Cr}$, aqui evidenciados através de análise por EDS (Figura 56 e Figura 57).

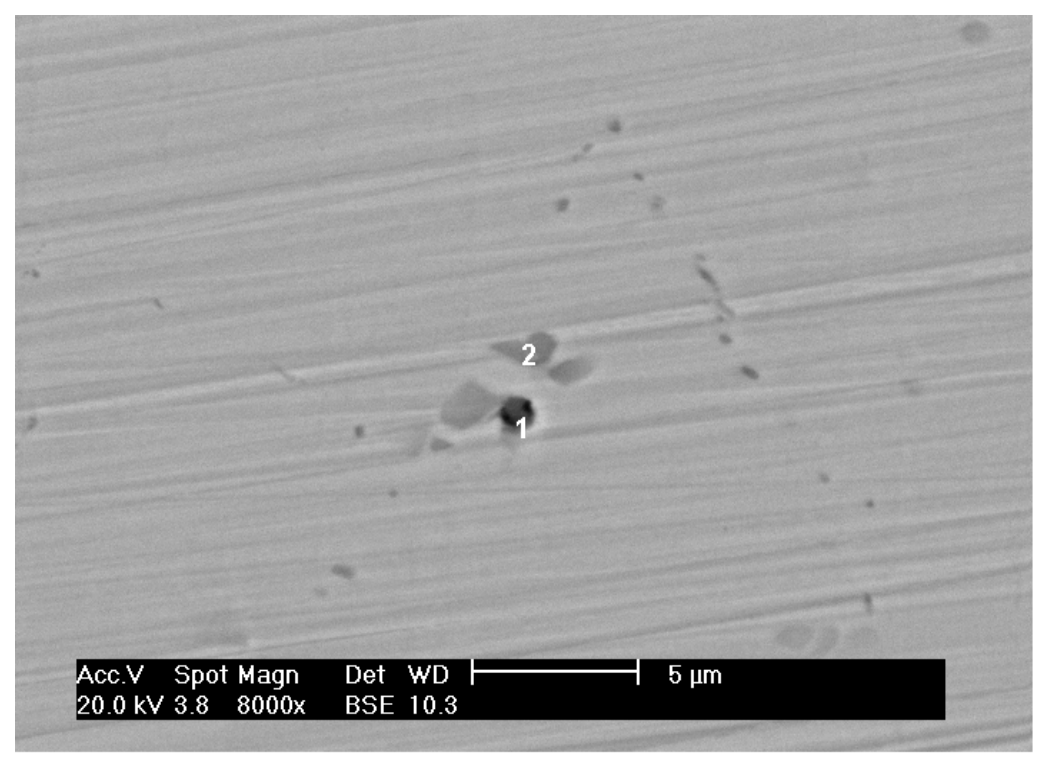

Figura 56 - Imagem de elétrons retroespalhados. Aspecto de duas inclusões (formato globular) encontradas na superfície do aço 316L após polimento até $1 \mu \mathrm{m}$. Aumento de $8000 \mathrm{x}$.

1

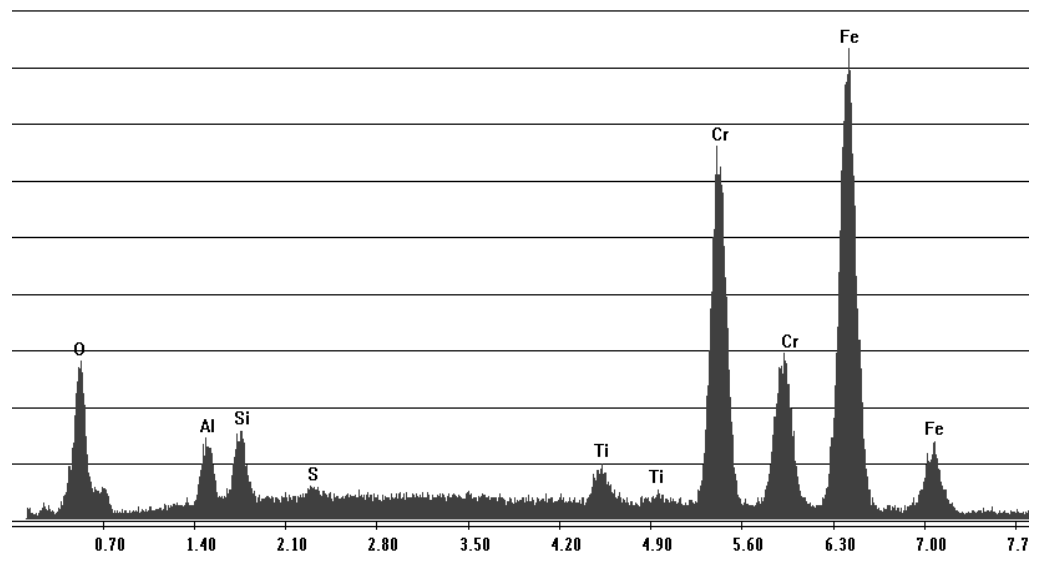

(a) 
2

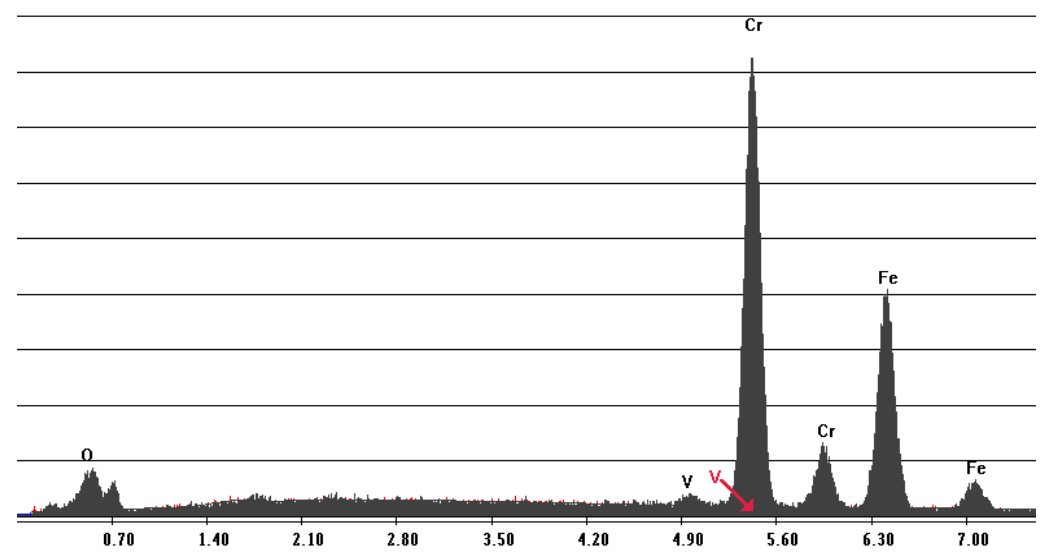

(b)

Figura 57 - Espectro de analises por EDS realizada nas inclusões (ponto 1 e ponto 2). Cabe ressaltar que os picos de Fe (Figura $57(\mathrm{a})$ e (b)) correspondem à matriz do aço

$\mathrm{Na}$ Figura 58 é mostrada uma inclusão com formato irregular. É importante ressaltar que esta inclusão apresenta cores distintas, o que indica diferenças significativas na sua composição química. De fato, como no caso anterior, a região mais escura (ponto 1 da Figura 58) revela a presença predominante $\mathrm{Si}$, além de $\mathrm{Al}$ e outros elementos, portanto, indicando a presença de inclusão de óxido Al e Si (Figura 59(a)). Por sua vez, a região cinza indicada por ponto 2 , revela a presença acentuada de $\mathrm{Cr}$. Isso indica que estas fases mais claras são carbonetos de $\mathrm{Cr}$ (Figura 59(b)), esperados na microestrutura do aço 430 . 


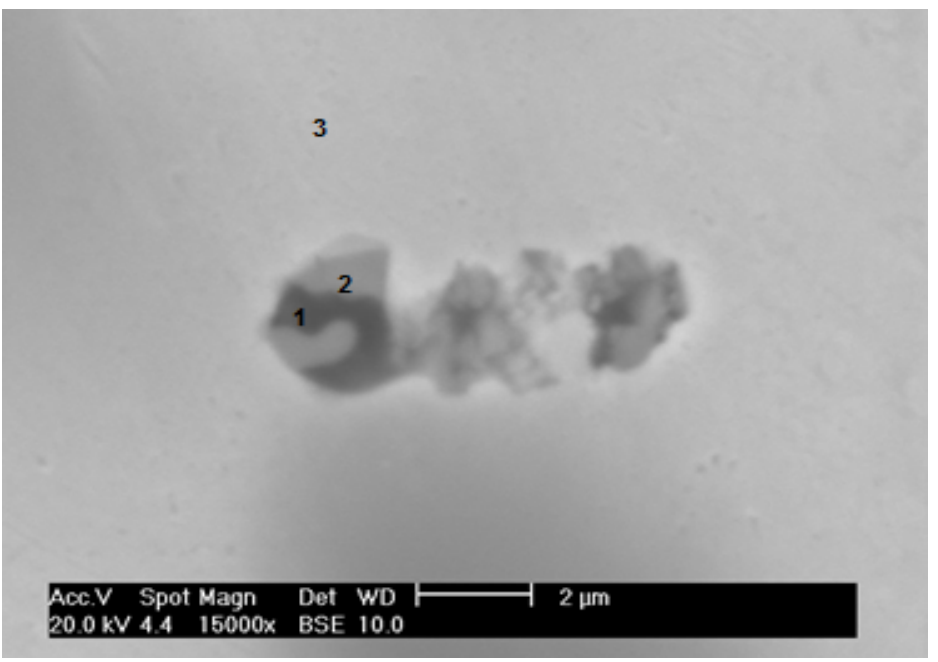

Figura 58 - Imagem de elétrons retroespalhados da superfície do aço 430, sem ataque, apresentando 0 aspecto das inclusões encontradas. $O$ polimento foi realizado até $1 \mu \mathrm{m}$. Aumento de 15000x.

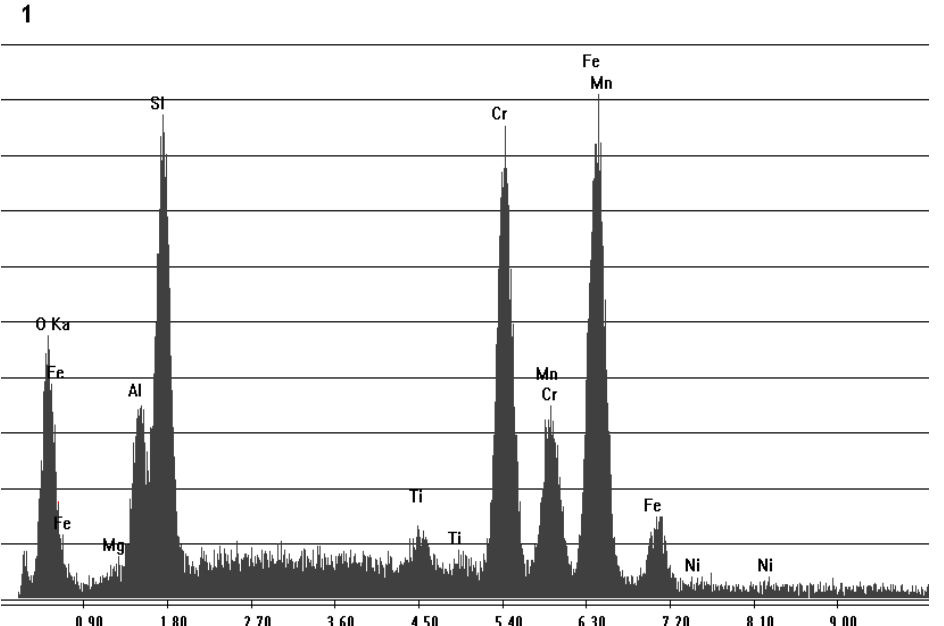

(a) 
2

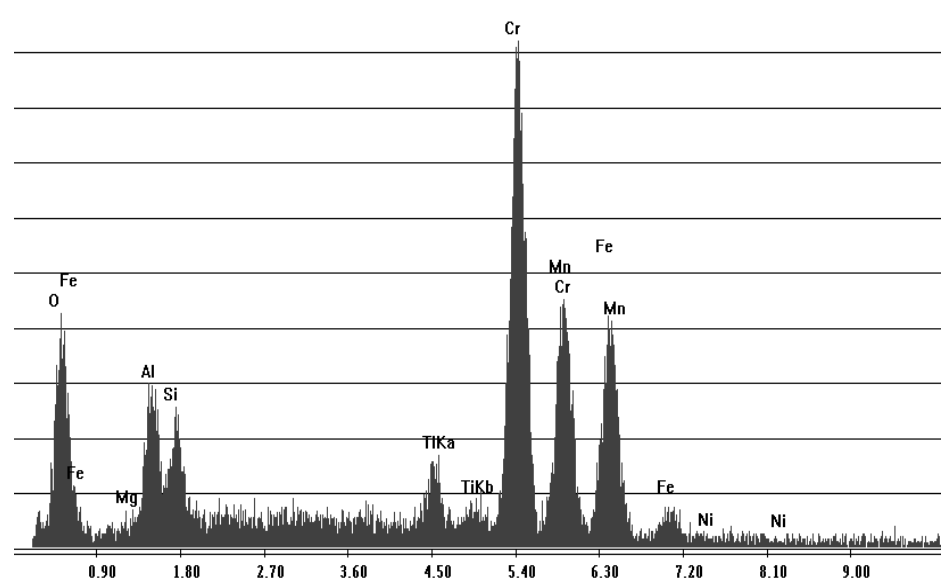

(b)

3

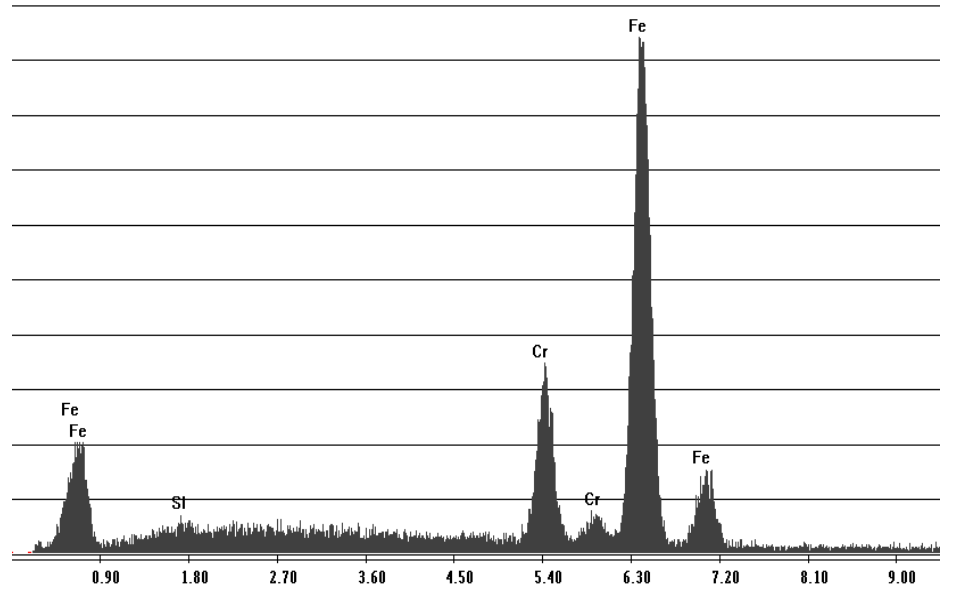

(c)

Figura 59 - Análise por EDS realizada para determinar a composição química da inclusão: (a) ponto 1; do carboneto de cromo: ponto (2) e da matriz ponto (3) para comparação.

A Figura 60 apresenta duas inclusões não metálicas. Foi realizada uma análise por EDS para determinar a composição química da inclusão no ponto 1. Os resultados para o ponto 1 (Figura 61(a)) mostram teores altos de $\mathrm{Si}$, e menores quantidades de $\mathrm{Ca}, \mathrm{Al}$ e Ba. Trata-se, portanto, de uma inclusão mista de óxido desses elementos. 


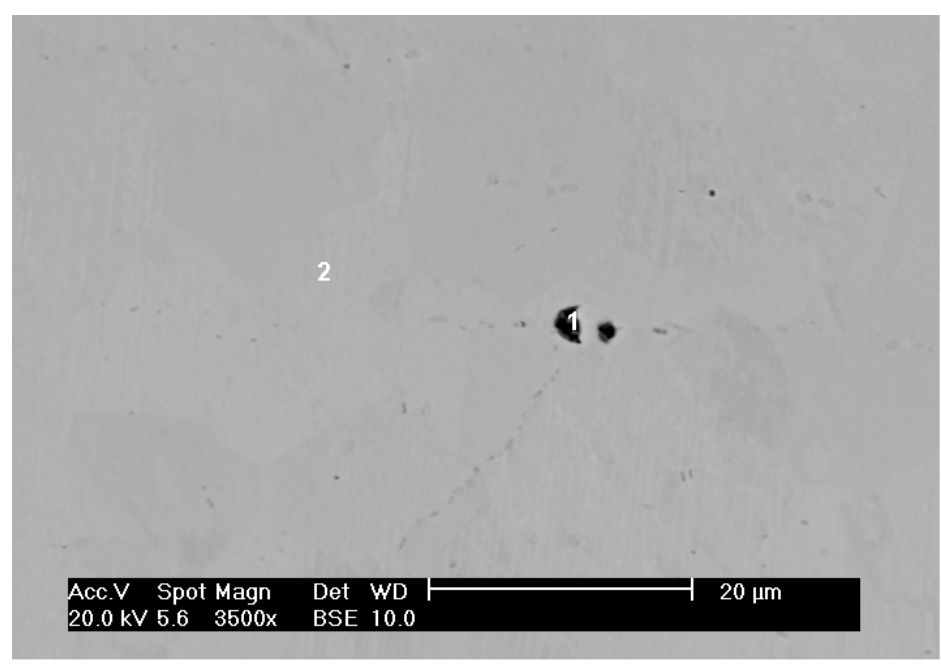

Figura 60 - Imagem de elétrons retroespalhados da superfície do aço 430, polido até $1 \mu \mathrm{m}$ sem ataque. Inclusões não metálicas presentes no material. Aumento de 3500x.

1

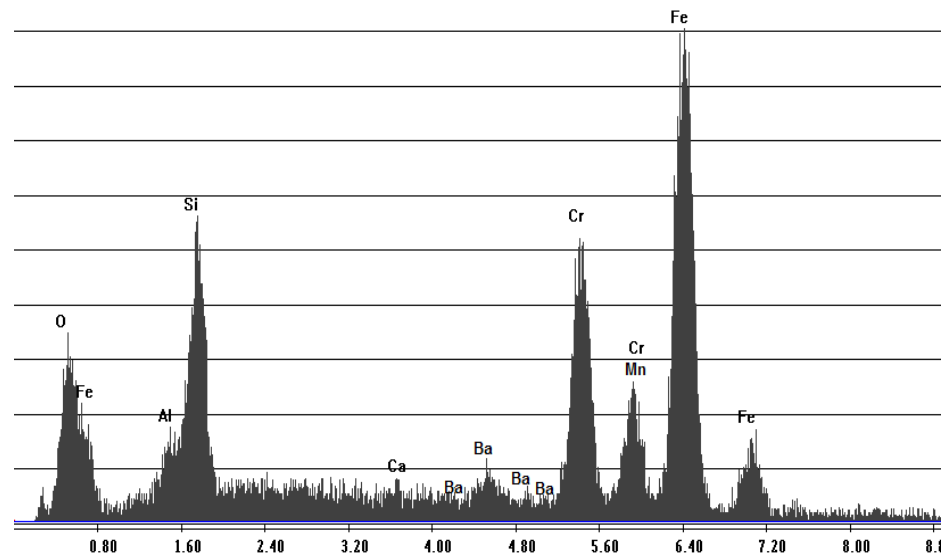

(a) 


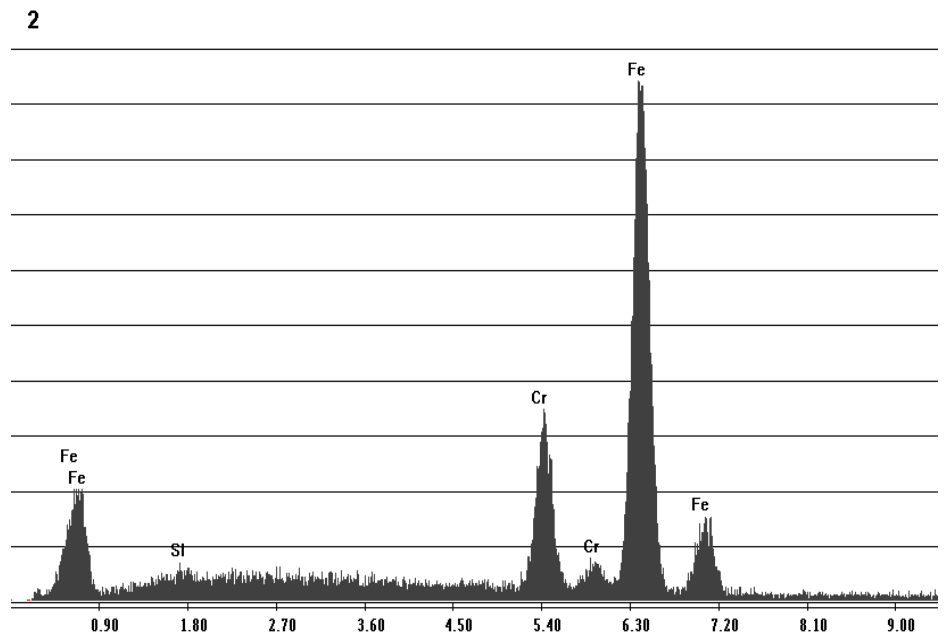

(b)

Figura 61 - Composição química obtida por análise por EDS: (a) ponto 1 - inclusão e (b) ponto 2 - matriz.

A microestrutura do aço 430 é mostrada na Figura 62. Conforme já foi mencionado, o ataque utilizado foi o eletrolítico em ácido oxálico 10\%, sendo que as cavidades observadas são as regiões onde havia a precipitação de carbonetos de cromo. Nota-se a presença de carbonetos globulares intragranulares, resultado do tratamento térmico de recuperação da sensitização, a que são submetidos estes aços, e também, carbonetos nos contornos de grão de ferrita - intergranulares 


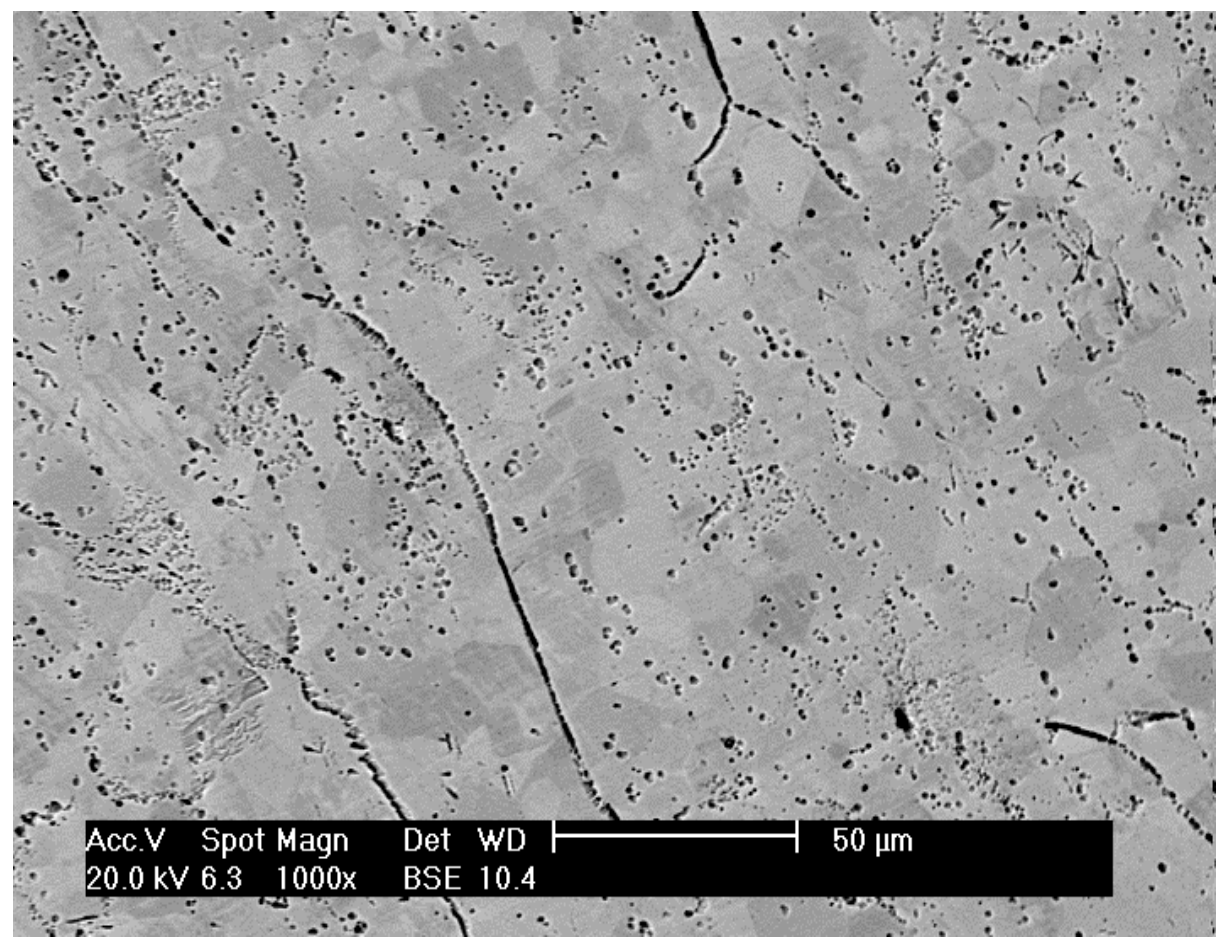

Figura 62 - Microestrutura do aço inoxidável ferrítico 430. Nota-se a matriz constituída de grãos recristalizados de ferrita e a presença de cavidades, indicando que aí havia precipitados de carbonetos de cromo, intragranulares e intergranulares. Imagem de elétrons retroespalhados. Ataque eletrolítico com ácido oxálico 10\%. Aumento 1000x.

\subsubsection{AÇO 444}

A Figura 63 apresenta de forma geral a distribuição das inclusões formadas na superfície do material. Cabe ressaltar que, como no caso do aço 316L e 430, este também apresenta uma grande densidade de inclusões não metálicas, quando comparado aos aços 298 e 304. 


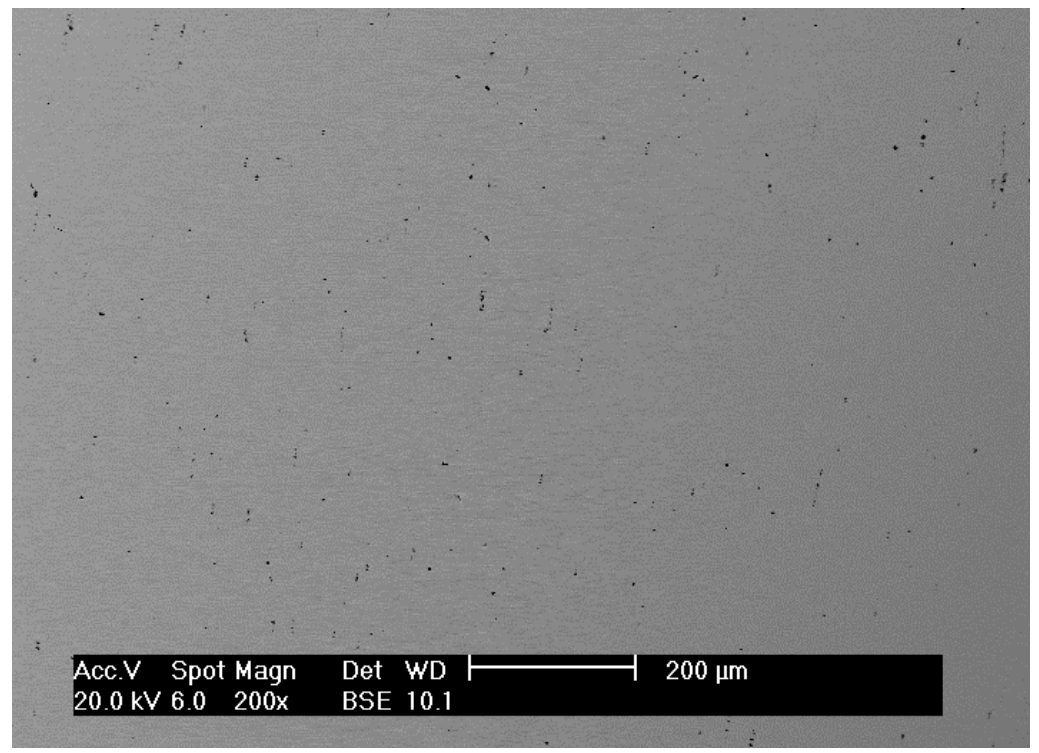

Figura 63 - Distribuição das inclusões no aço inoxidável ferrítico 444. Polimento superficial até $1 \mu \mathrm{m}$. Imagem de elétrons retroespalhados com um aumento de 1000x.

Na Figura 64 se exibem inclusões não metálicas com formatos alongados e irregulares. Para determinar a composição química das inclusões foram realizadas análises por EDS.

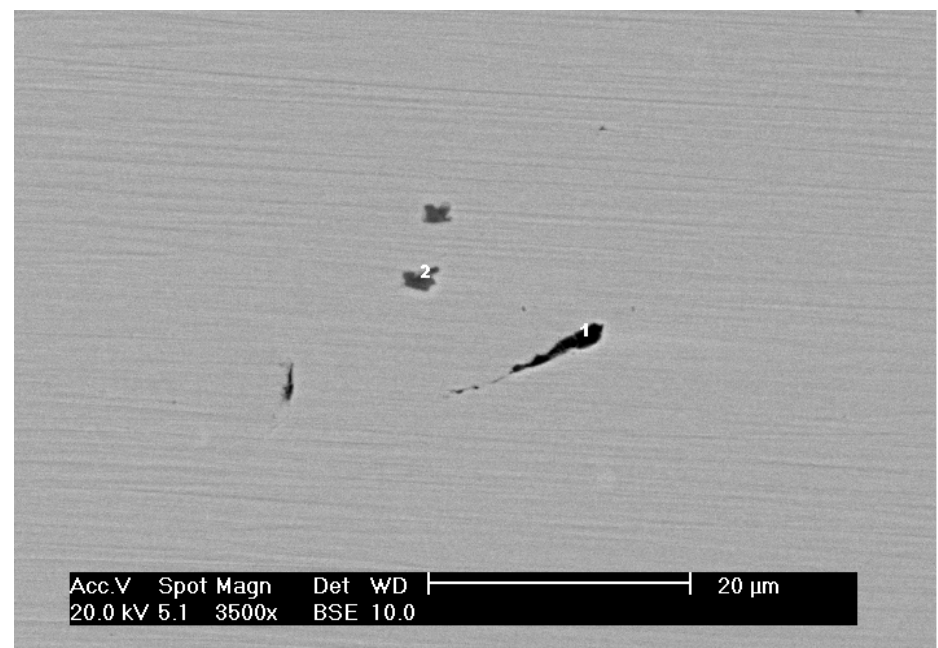

Figura 64 - Imagem de elétrons retroespalhados da superfície do aço 444, polido até $1 \mu \mathrm{m}$ sem ataque. Inclusões não metálicas presentes no material. (a) inclusão de cor preta alongada: ponto 1 e (b) inclusão cinza: ponto 2 . Aumento de 3500x. 
O resultado desta análise é mostrado na Figura 65, através do qual se observa uma inclusão (ponto 1) que contém elevado teor de Si (inclusão de óxido de Si). Já no ponto 2 , o espectro obtido revela uma fase rica em $\mathrm{Ti}$ e $\mathrm{Nb}$. Como esse aço contém em sua composição química Ti e Nb para evitar a precipitação de carbonetos de $\mathrm{Cr}$, pode-se concluir que se trata de carboneto de $\mathrm{Ti}$ e $\mathrm{Nb}$.

1

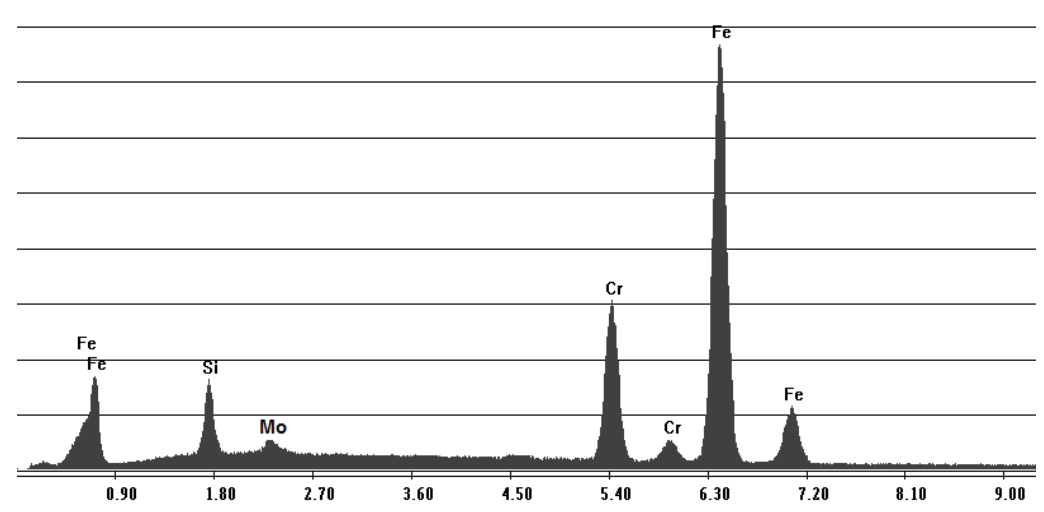

(a)

2

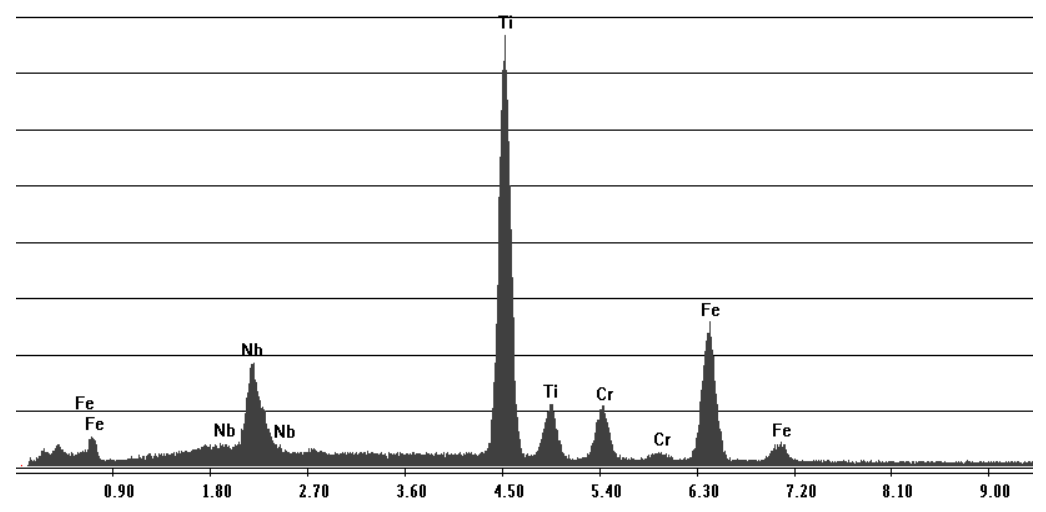

(b) 


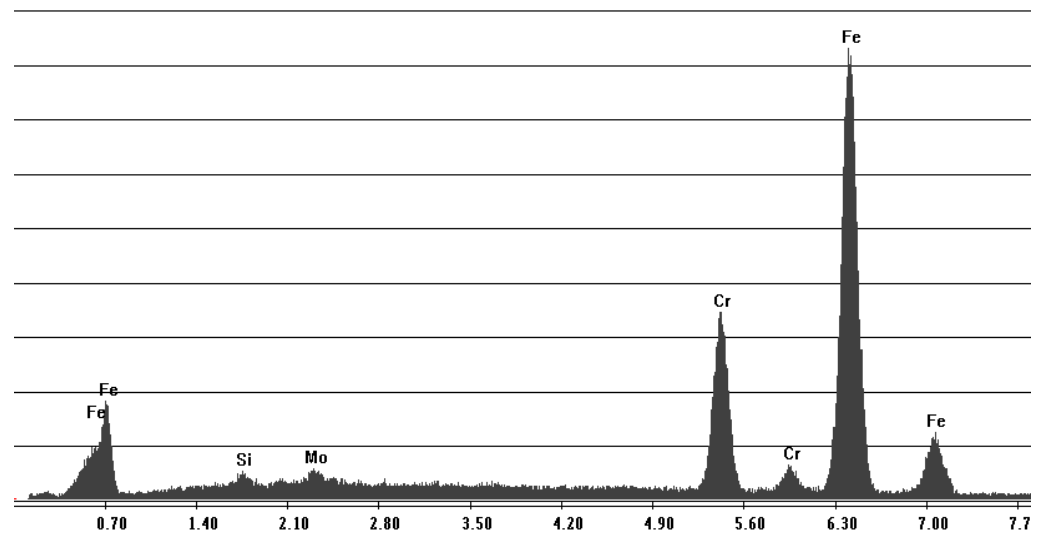

(c)

Figura 65 - Análise por EDS realizada para determinar a composição química das inclusões: (a) ponto 1 :inclusão preta, (b) ponto 2: inclusão cinza e (c) matriz para efeito de comparação.

$\mathrm{Na}$ Figura 66 é mostrada uma inclusão com formato irregular que possivelmente foi quebrada em algum processo de laminação ou de conformação mecânica. É importante ressaltar que esta inclusão apresenta cores distintas, indicando desta forma, que são apresentadas diferenças significativas na sua composição química.

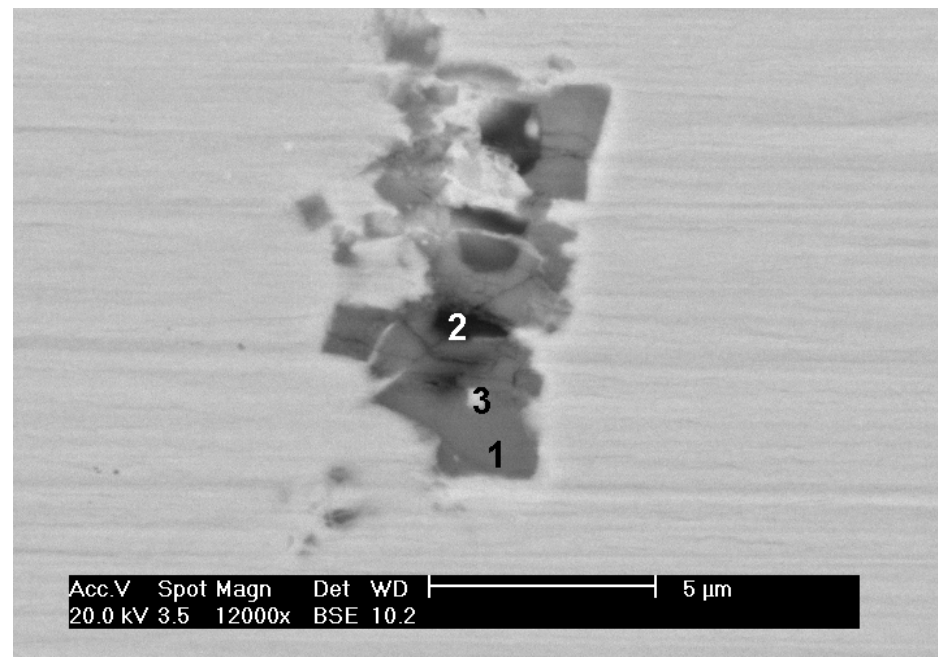

Figura 66 - Imagem de elétrons retroespalhados da superfície do aço 444, polido até 1 um sem ataque. Nota-se cores distintas na inclusão, o que significa uma diferença de composição química. (a) Ponto 1: rica em titânio, (b) ponto 2: óxidos de Al (cor preta) e (c) ponto 3: nitretos de titânio. Aumento de 12000x. 
Foram feitas análises por EDS nos pontos 1, 2 e 3 cujos resultados estão apresentados na Figura 67. A Figura 67(a) mostra que no ponto 1 tem-se uma fase rica em Ti, provavelmente carboneto/nitreto de Ti. Já no ponto 2 (Figura 67(b)) se observam teores altos de Al e Mg além de outros elementos e, ainda, sinais da presença de $\mathrm{S}$. Pode-se afirmar aqui que se trata de uma inclusão de óxido de Al com sulfeto de Mg. A análise no ponto 3 (Figura 67(c)) mostra uma fase rica em $\mathrm{Ti}$ e foi possível identificar a presença de $\mathrm{N}$, evidenciado que existe a precipitação nitretos de Ti neste material.

1

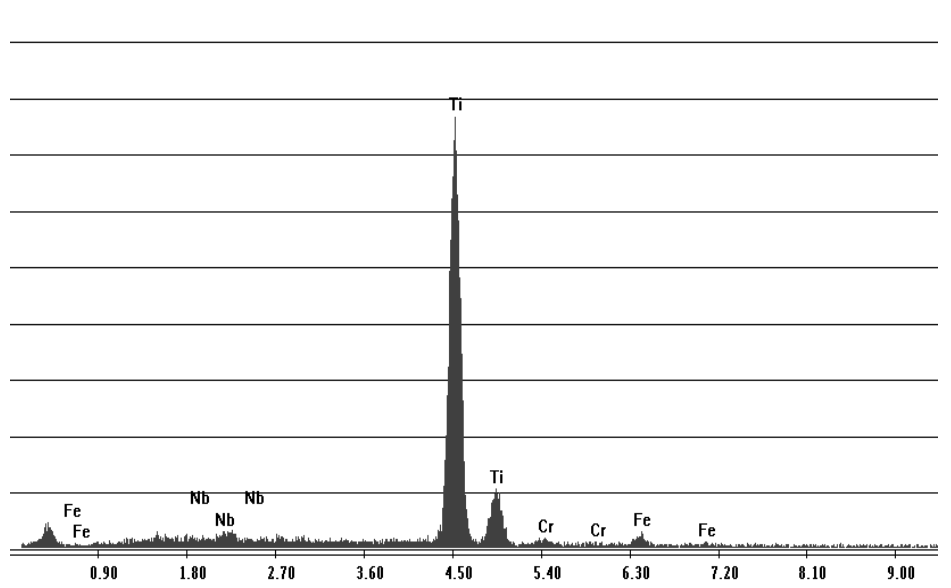

(a)

2

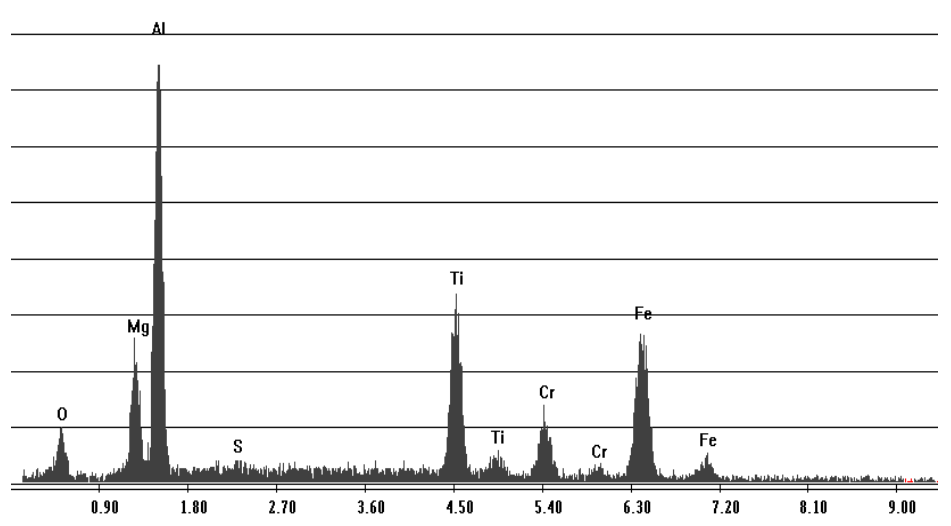

(b) 


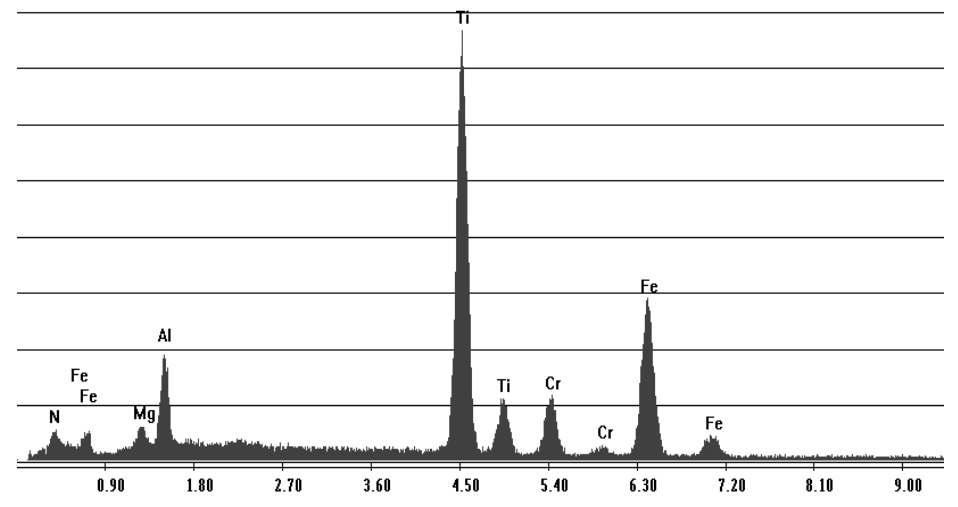

(c)

Figura 67 - Análise por EDS realizada para determinar a composição química da inclusão. (a) Ponto 1: região rica em titânio, (b) ponto 2: óxido de Al (cor preta) e (c) ponto 3: nitreto de titânio.

Na Figura 68 é mostrada uma inclusão contendo duas regiões (cores distintas), uma mais clara e outra mais escura, o que indica uma diferença significativa na composição química. O resultado da análise por EDS é mostrado na Figura 69 ponto 1, que é a região mais escura. Devido ao pequeno tamanho dessa inclusão, não foi possível analisar as duas regiões: clara na borda e escura central. O resultado (Figura 69) revela que se trata de uma inclusão rica em Al e que provavelmente, a região da borda, mais clara, pode ser um composto de Ti (carboneto ou nitreto). 


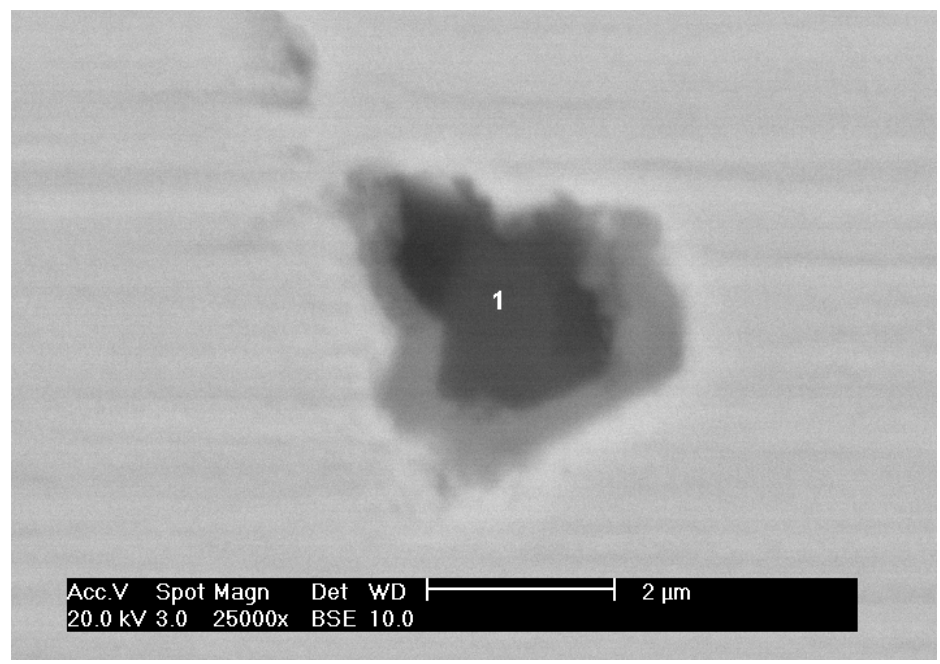

Figura 68 - Imagem de elétrons retroespalhados da superfície do aço 444, polido até $1 \mu \mathrm{m}$ sem ataque. Nota-se cores distintas (cor cinza na borda) na inclusão, o que significa uma diferença de composição química. Aumento de 25000x.

1

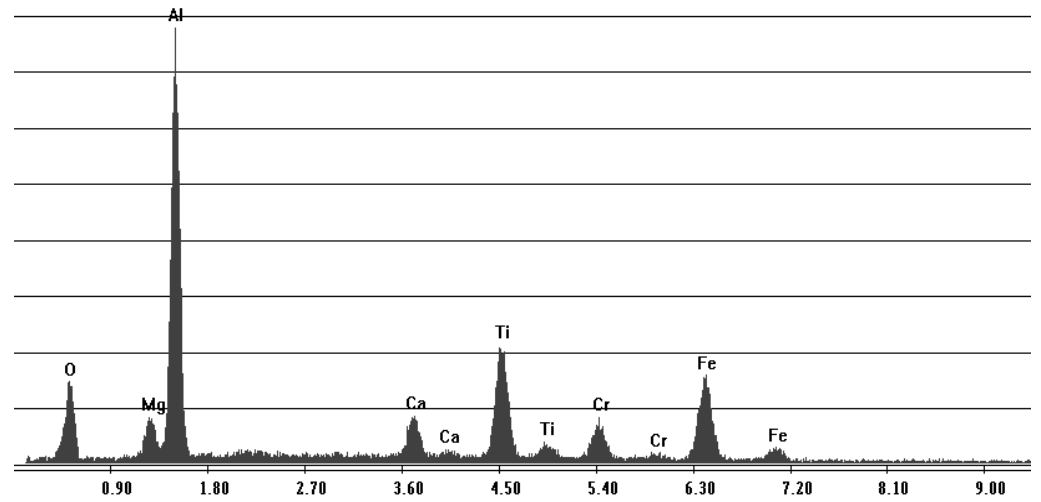

Figura 69 - Análise por EDS realizada para determinar a composição química da inclusão. Cabe ressaltar que não é possível determinar a composição química das duas regiões devido ao pequeno tamanho da inclusão.

A Figura 70 apresenta a microestrutura do aço 444 após ataque eletrolítico com ácido oxálico 10\%. Nota-se que a microestrutura é composta de grãos de ferrita recristalizados. Notam-se ainda, pontos escuros que correspondem, provavelmente, à dissolução de inclusões. 


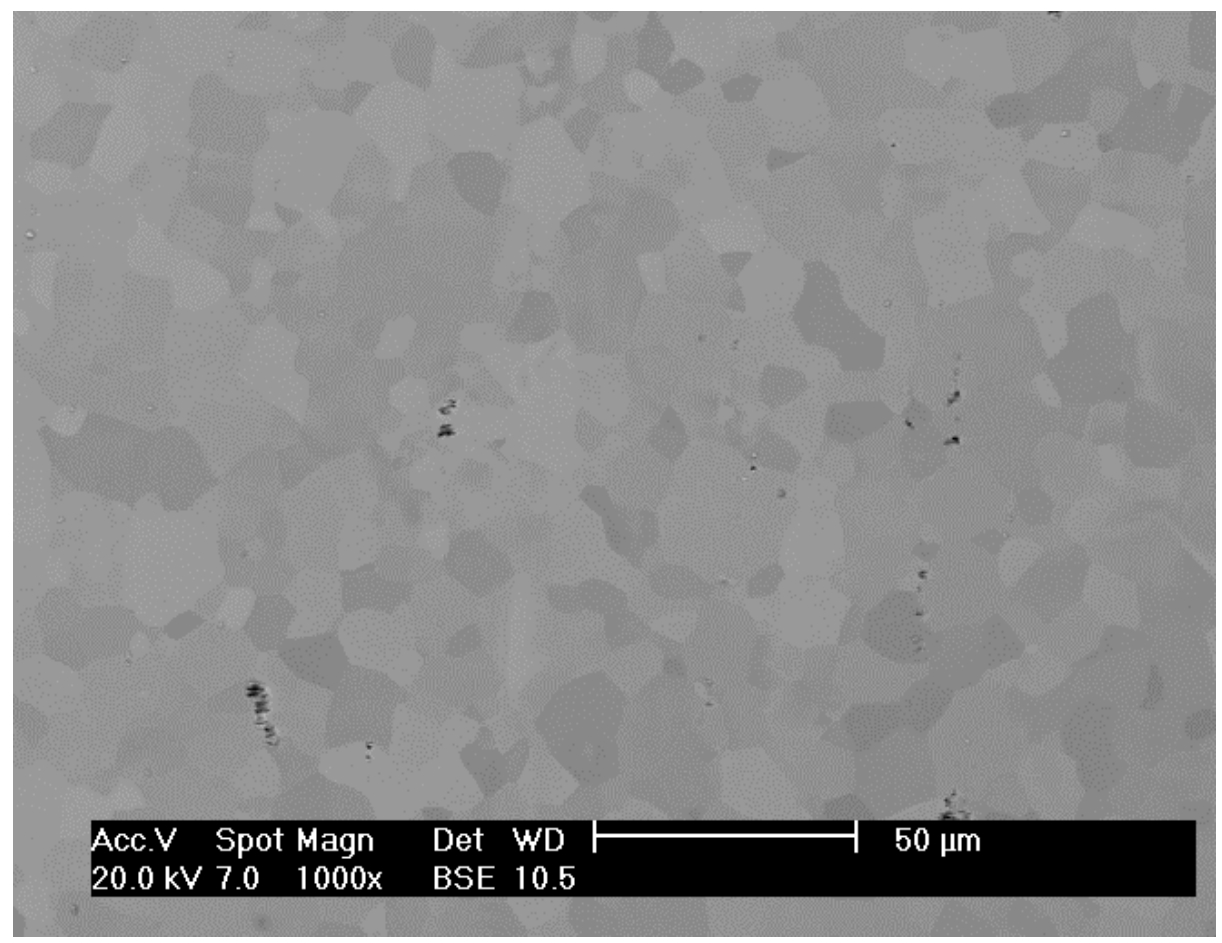

Figura 70. Microestrutura do aço inoxidável ferrítico 444. Aumento de 1000x. Nota-se a matriz constituída de grãos recristalizados de ferrita e a presença de algumas cavidades, provenientes da dissolução de inclusões. Imagem de elétrons retroespalhados. Ataque eletrolítico com ácido oxálico $10 \%$.

\section{COMENTÁRIOS GERAIS SOBRE A CARACTERIZAÇÃO MICROESTRUTUAL}

Primeiramente destaca-se que todos os aços inoxidáveis aqui estudados são soluções sólidas homogêneas de austenita ou ferrita. A microestrutura sempre se apresentou como uma estrutura típica de materiais solubilizados e/ou recozidos, ou seja, grãos de austenita recristalizados, apresentando maclas de recozimento, para os aços austeníticos, e grãos de ferrita recristalizados para os aços ferríticos. Quando à distribuição de inclusões, os aços caracterizaram-se por apresentar inclusões de tamanhos muito próximos, no entanto, os aços 430, 444 e 316L apresentaram maior densidade de inclusões do que os aços 298 e 304. Quando à natureza das inclusões foram encontradas óxidos de $\mathrm{Si}, \mathrm{Al}$, e $\mathrm{Ca}$, óxido de $\mathrm{Si}$, mistura de óxido de $\mathrm{Si}$ e sulfetos de $\mathrm{Mn}, \mathrm{MnS}$, óxido de $\mathrm{Al}$, óxido de $\mathrm{Ca}, \mathrm{Si}, \mathrm{Mg}$ e Al, mistura de óxido de $\mathrm{Si}$ e Al e MnS, mistura de óxido de Al e sulfeto de Ti, carboneto de $\mathrm{Cr}$, mistura 
de óxido de $\mathrm{Al}$ e Si e carboneto de $\mathrm{Cr}$, carboneto de $\mathrm{Ti}$ e $\mathrm{Nb}$ e uma mistura de carboneto/nitreto de Ti e óxido de Al+sulfeto de Mg.

A Tabela 6 apresenta um resumo das principais inclusões encontradas nos aços do presente estudo.

Tabela 6 - Resumo das principais inclusões encontradas nos aços do presente estudo.

\begin{tabular}{|c|c|c|}
\hline AÇO & INCLUSÕES & \\
\hline \multirow{4}{*}{298} & Óxido de Al, Si e Ca & Figura 26 \\
\hline & Óxido de Si & Figura 28 \\
\hline & Mistura de óxido de Si e MnS & Figura 30 \\
\hline & $\overline{M n S}$ & Figura 32 \\
\hline \multirow{4}{*}{304} & Óxido de Al & Figura 36 \\
\hline & Oxido de $\mathrm{Ca}$, Si Mg e Al & Figura 38 \\
\hline & Oxido de $\mathrm{Mg}, \mathrm{Si}$ e $\mathrm{Ca}$ & Figura 40 \\
\hline & $\overline{M n S}$ & Figura 42 \\
\hline \multirow{3}{*}{ 316L } & Óxido de Si & Figura 46 \\
\hline & Mistura óxido de Si e Al e MnS & Figura 48 \\
\hline & $\mathrm{MnS}$ & Figura 50 \\
\hline \multirow{4}{*}{430} & Óxido de Al & Figura 54 \\
\hline & $\begin{array}{l}\text { Mistura de óxido de Al e sulfeto de } \mathrm{Ti} \\
\text { Carboneto de } \mathrm{Cr}\end{array}$ & Figura 56 \\
\hline & $\begin{array}{l}\text { Oxido de } \mathrm{Al} \mathrm{e} \mathrm{Si} \\
\text { Carboneto de } \mathrm{Cr}\end{array}$ & Figura 58 \\
\hline & Oxido de Al e Si, contendo $\mathrm{Ba}$ & Figura 60 \\
\hline \multirow[b]{2}{*}{444} & $\begin{array}{l}\text { Óxido de } \mathrm{Si} \\
\text { Carboneto de } \mathrm{Ti} \text { e } \mathrm{Nb}\end{array}$ & Figura 64 \\
\hline & $\begin{array}{l}\text { Carbonitrato de Ti } \\
\text { Mistura de óxido de Al e MnS } \\
\text { Nitreto de Ti }\end{array}$ & Figura 66 \\
\hline
\end{tabular}




\subsection{ENSAIOS DE POLARIZAÇÃO POTENCIODINÂMICA}

Conforme mencionado no capítulo de Materiais e Métodos, a resistência à corrosão por pite foi avaliada a partir do levantamento de curvas de polarização, pelo método da polarização potenciodinâmica, em eletrólitos contendo 0,6M de concentração de íons agressivos (cloreto e brometo), em 04 (quatro) composições diferentes. A seguir, apresentam-se os principais resultados obtidos nestes ensaios.

\subsubsection{FORMA DAS CURVAS DE POLARIZAÇÃO OBTIDAS PARA OS DIFERENTES AÇOS INOXIDÁVEIS}

\subsubsection{AÇO INOXIDÁVEL AUSTENÍTICO 298}

As curvas típicas de polarização potenciodinâmica obtidas para o aço inoxidável 298, nos diferentes eletrólitos, estão apresentados nas Figura 71 e Figura 72. Já na Figura 73 é mostrada a sobreposição destas curvas. Nestes gráficos pode-se observar que as curvas obtidas apresentam trecho catódico, seguidas de trecho passivo bem definido. Com o aumento do potencial aplicado, ocorrem oscilações da densidade de corrente, características da ocorrência de pites instáveis (pites que iniciam o crescimento e sofrem repassivação diversas vezes), até que para determinado potencial, ocorre a nucleação e crescimento de pelo menos um pite com crescimento contínuo. Os pites instáveis foram mais comuns para os eletrólitos de misturas de $\mathrm{NaCl}$ e $\mathrm{NaBr}$ do que para seus respectivos eletrólitos puros. Cabe salientar que as curvas obtidas apresentaram potencial de pite (Ep), bem definidos e de fácil leitura.

O trecho catódico nestas curvas corresponde à reação catódica de oxigênio. Como os eletrólitos empregados não foram desaerados, o oxigênio dissolvido é o responsável pela curva catódica obtida. A reação catódica de hidrogênio está descartada, pois o potencial de equilíbrio dessa reação ocorre em valores bem mais baixos. Por exemplo, o eletrólito de $0,6 \mathrm{M} \mathrm{NaCl}$ tem $\mathrm{pH}$ de 
aproximadamente 6,0 , o que fornece para o eletrodo de $\mathrm{Ag} / \mathrm{AgCl}$, valores na faixa de -648 a $-559 \mathrm{mV}, \mathrm{Ag} / \mathrm{AgCl}$ (em função da concentração de cloreto do eletrodo de referência empregado). No presente caso, a curva catódica de hidrogênio está fora dos potenciais de eletrodos utilizados.

A Figura 73 mostra ainda que os valores dos Ep são relativamente próximos, em função das diferenças de composição química dos eletrólitos. Mais adiante, estão apresentados os valores médios de $\mathrm{Ep}$, onde a dependência com a composição do eletrólito torna-se mais evidente.

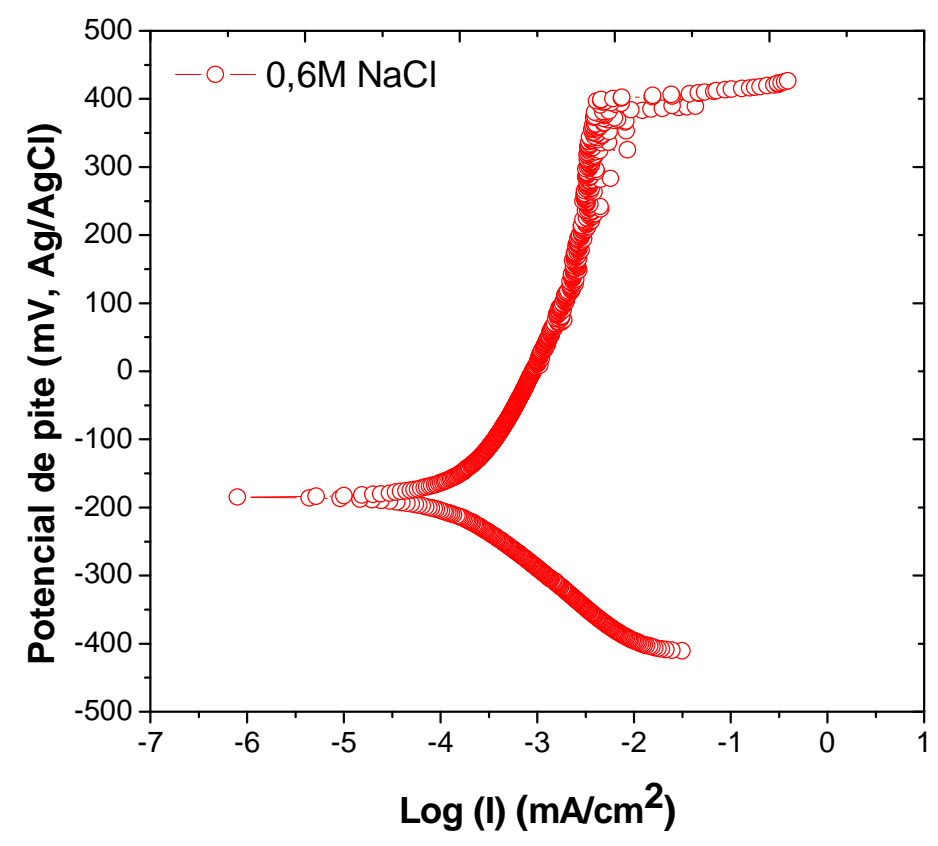

(a) 


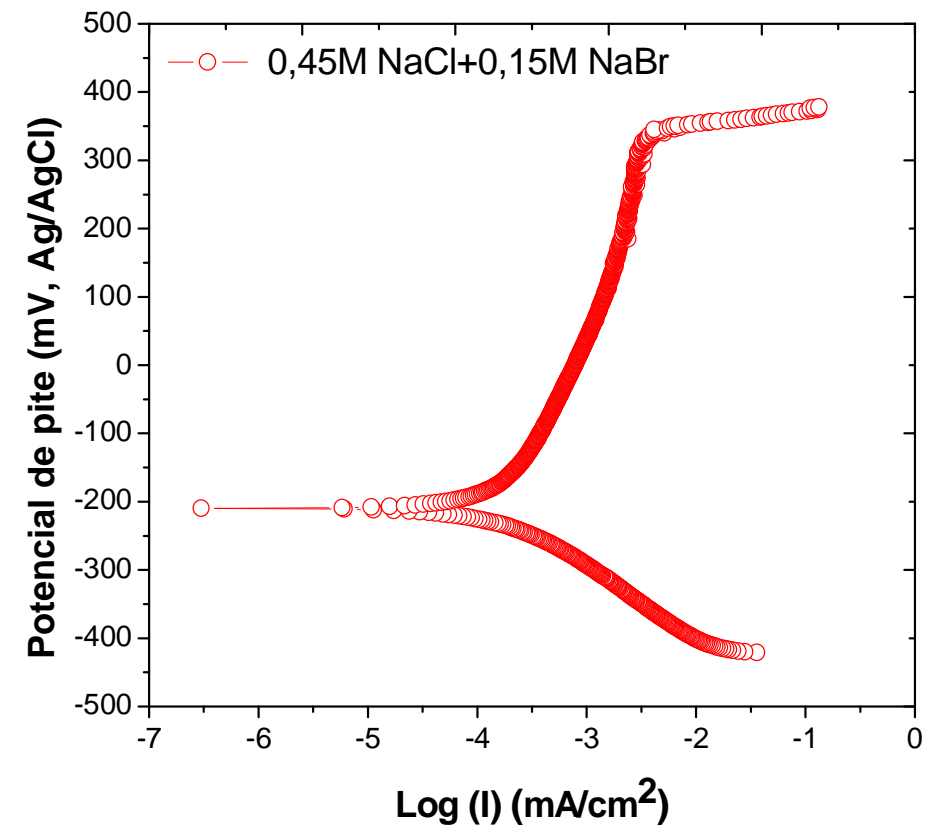

(b)

Figura 71. Curvas de polarização do aço inoxidável austenítico 298. (a) $0,6 \mathrm{M} \mathrm{NaCl}$ e (b) $0,45 \mathrm{M}$ $\mathrm{NaCl}+0,15 \mathrm{M} \mathrm{NaBr}$.

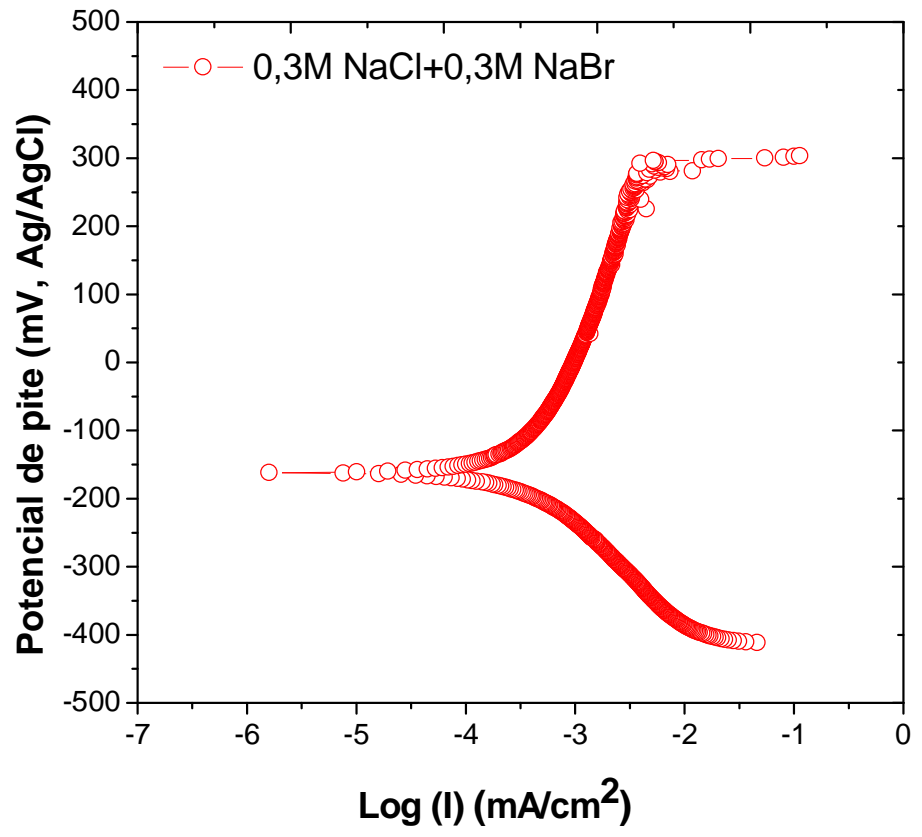

(a) 


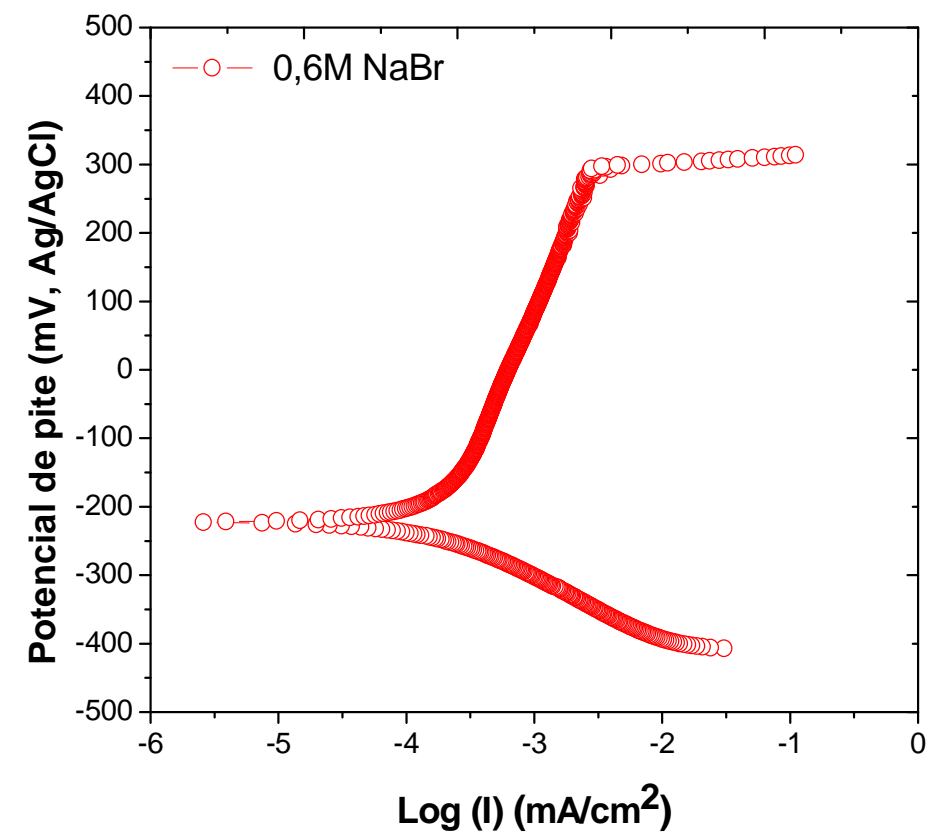

(b)

Figura 72. Curvas de polarização do aço inoxidável austenítico 298. (a) $0,3 \mathrm{M} \mathrm{NaCl}+0,3 \mathrm{M} \mathrm{NaBr}$ e (b) $0,6 \mathrm{M} \mathrm{NaCl}$.

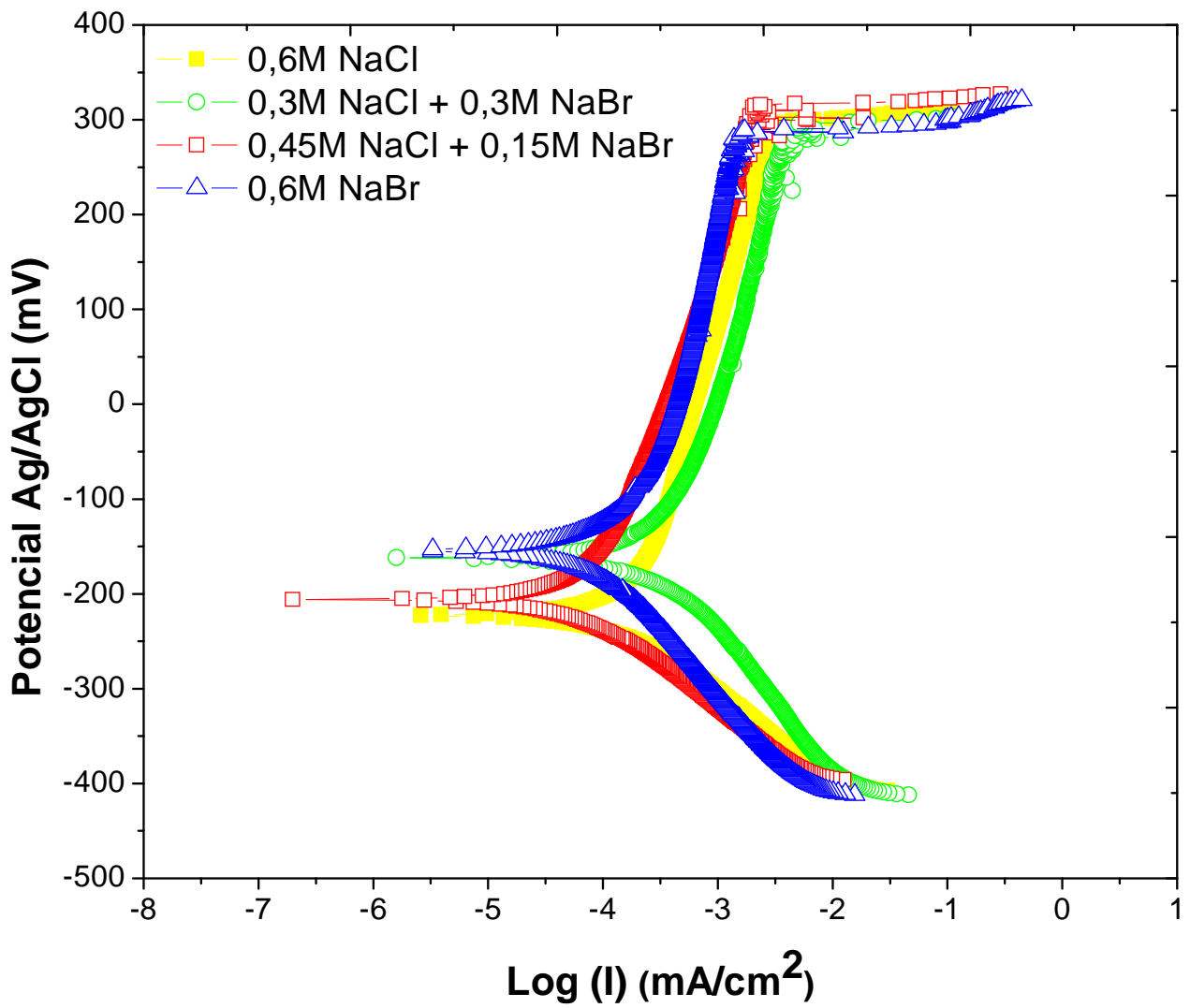

Figura 73 - Sobreposição das curvas de polarização do aço inoxidável austenítico 298 em meios contendo cloreto, brometo e suas misturas. 


\subsubsection{AÇO INOXIDAVEL AUSTENITICO 304}

De modo análogo ao aço 298, as Figura 74 e Figura 75 apresentam as curvas de polarização para o aço 304 .

A forma das curvas obtidas é muito semelhante ao caso do aço 298: há trecho catódico bem definido de reação de oxigênio, seguido do trecho passivo e da definição do Ep. Nota-se através das Figura 74 e Figura 75, que para 0 eletrólito de $0,6 \mathrm{M} \mathrm{NaCl}$, ocorre forte oscilação da densidade de corrente, em potenciais próximos ao Ep. Por sua vez, com a adição de brometo $(\mathrm{NaBr})$ estas oscilações tornam-se mínimas, tendendo a desaparecer. Supondo-se que tais oscilações indicam a ocorrência de pites instáveis, tem-se aqui uma evidência do efeito do brometo sobre a nucleação desse tipo de pite: aparentemente, a presença de brometo inibe a formação de pites instáveis, ou seja, quando pites são nucleados, eles crescem continuamente.

Quanto aos valores de Ep para este aço, a Figura 76 mostra que a composição química do eletrólito tem um efeito maior sobre o valor de Ep, do que no caso do aço 298, uma vez que é possível observar um distanciamento entre os valores dos Ep. O aço 304 mostrou-se mais susceptível à alteração da composição do eletrólito. Outro ponto interessante é notar que, para os eletrólitos puros em $\mathrm{NaCl}$ e $\mathrm{NaBr}(0,6 \mathrm{M} \mathrm{NaCl}$ e $0,6 \mathrm{M} \mathrm{NaBr}$, Figura 50), foram obtidos os maiores valores de $\mathrm{Ep}$; ficando as misturas com os piores desempenhos. 


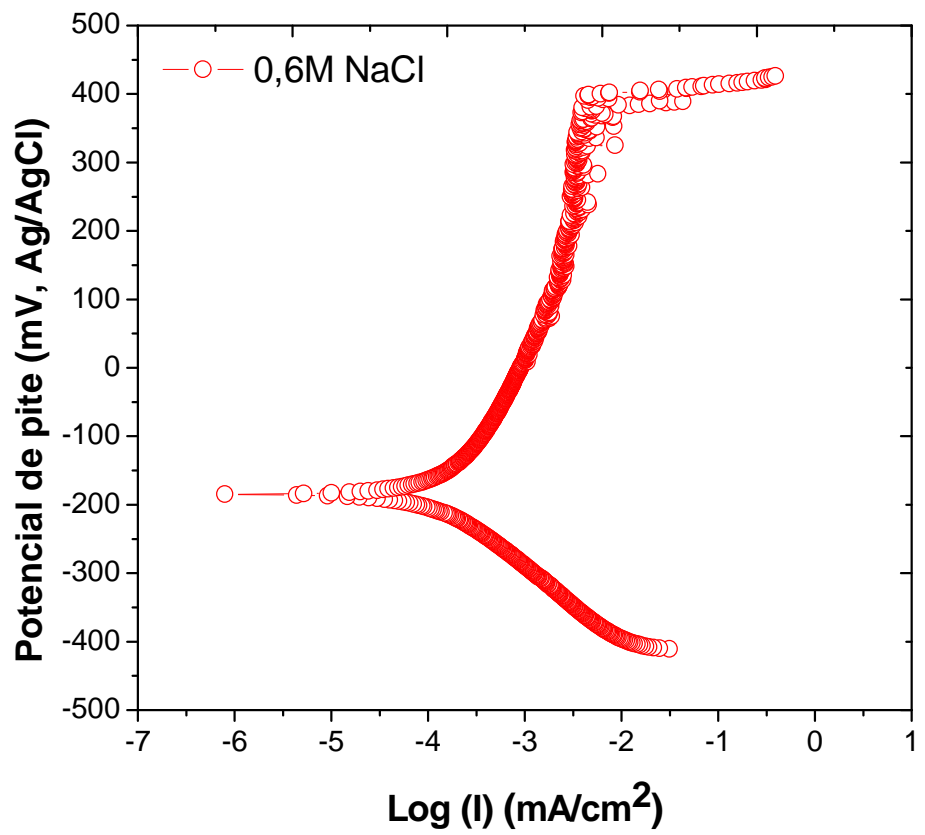

(a)

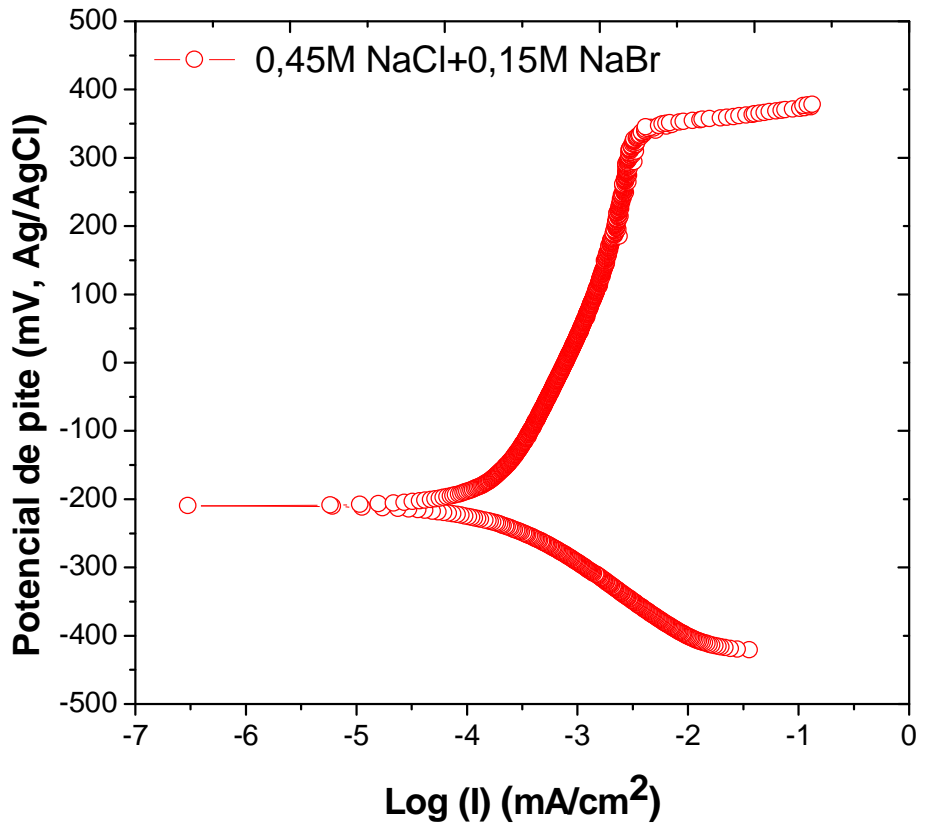

(b)

Figura 74. Curvas de polarização do aço inoxidável austenítico 304. (a) $0,6 \mathrm{M} \mathrm{NaCl}$ e (b) $0,45 \mathrm{M}$ $\mathrm{NaCl}+0,15 \mathrm{M} \mathrm{NaBr}$. 


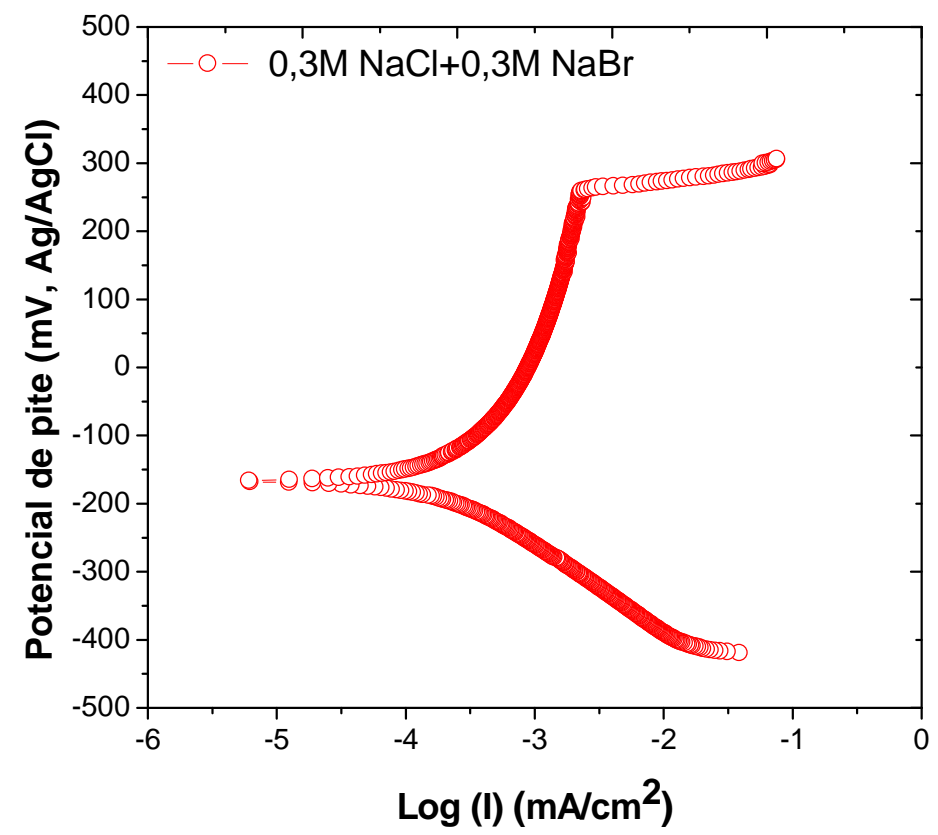

(a)

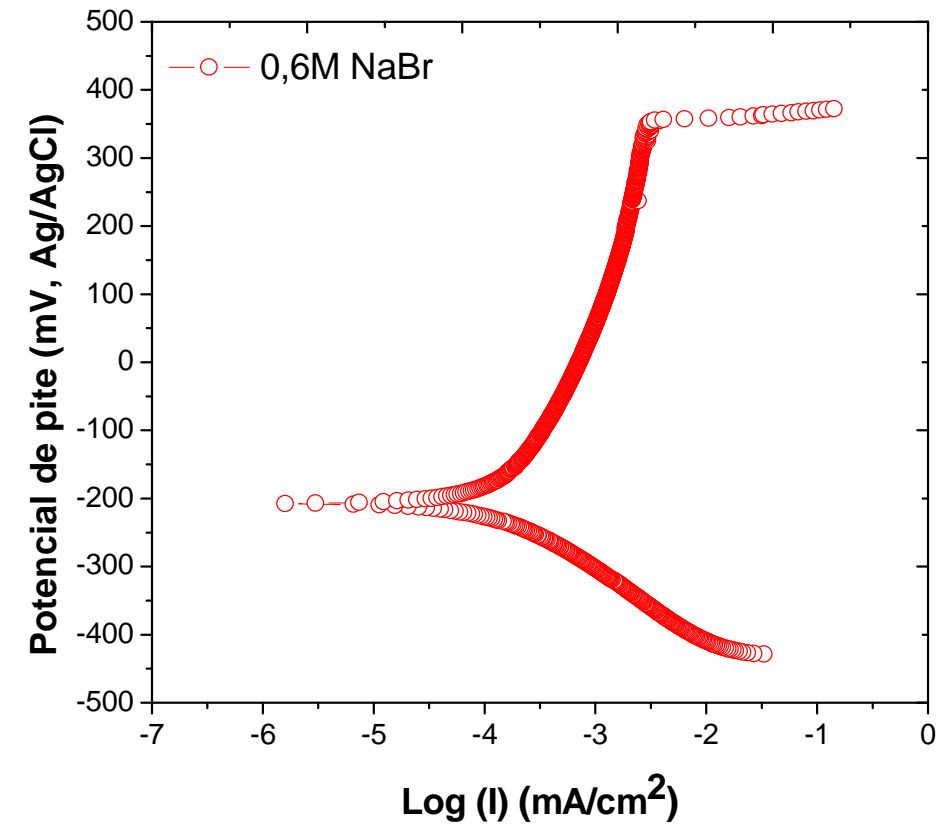

(b)

Figura 75 - Curvas de polarização do aço inoxidável austenítico 304. (a) $0,3 \mathrm{M} \mathrm{NaCl}+0,3 \mathrm{M}$ $\mathrm{NaBr}$. e (b) 0,6M NaBr. 


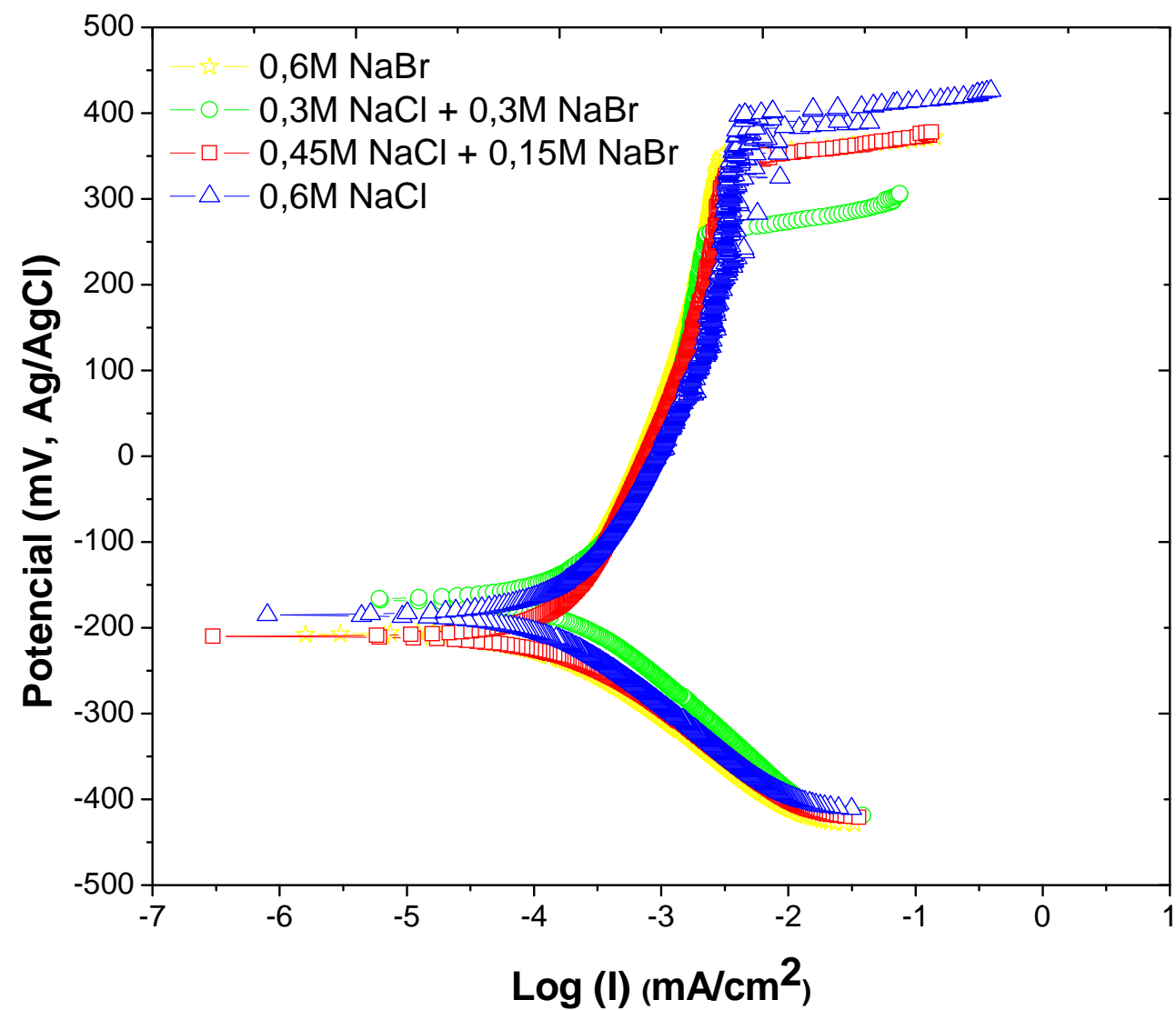

Figura 76 - Sobreposição das curvas de polarização do aço inoxidável austenítico 304 em meios contendo cloreto, brometo e suas misturas.

\subsubsection{AÇO INOXIDÁVEL AUSTENÍTICO 316L}

Nas Figura 77 e Figura 78 estão apresentadas as curvas de polarização potenciodinâmica típicas do aço 316L. Como nos casos anteriores (aços 298 e 304), manteve-se a forma da curva de polarização: trecho catódico da reação de oxigênio, trecho passivo bem definido, bem como, ótima definição do Ep. Comparativamente aos aços 298 e 304, o aço $316 \mathrm{~L}$ foi o que apresentou as menores ocorrências de pites instáveis, particularmente para os eletrólitos que continham brometo. Os pites instáveis ocorreram apenas para o eletrólito puro em $\mathrm{NaCl}(0,6 \mathrm{M})$. A explicação desse comportamento deve levar em conta o mecanismo pelo qual a presença de Mo em solução sólida no aço atua. Devese lembrar que o mecanismo de proteção do Mo, contra a corrosão por pite, é a sua dissolução logo após a ruptura da película passiva, com consequente 
formação de compostos de Mo e oxigênio(3) que irão repassivar o pite. Esse efeito se faz presente tanto nos eletrólitos de cloreto quanto de brometo.

Voltando ao aço 304, nota-se que este material também apresentou o mesmo comportamento quanto à ocorrência de pites instáveis nos eletrólitos mais ricos em $\mathrm{Cl}^{-}$, isto é, os pites instáveis foram mais freqüentes nos eletrólitos ricos em $\mathrm{Cl}^{-}$.

Sugere-se que esse comportamento está relacionado com a capacidade de acidificação do eletrólito no interior dos pites que cada tipo de sal proporciona. Quando um sal tem maior capacidade de hidrólise, a concentração de $\mathrm{H}^{+}$, no interior do pite, será maior, diminuindo mais acentuadamente o pH nessa região. Considerando-se que a repassivação dos pites (pites instáveis) depende do $\mathrm{pH}$ no seu interior, tem-se que eletrólitos de pH mais baixos não poderão apresentar a repassivação, desse modo, os pites crescem continuamente, impedindo a ocorrência dos chamados pites instáveis. De fato, a literatura(64) menciona que o ácido bromídrico é um ácido mais forte do que o ácido clorídrico, ou seja, a capacidade de acidificação é mais proeminente no caso do ácido bromídrico. No interior dos pites, aqui formados, são estes dois ácidos que estão presentes. Sendo o ácido bromídrico mais forte, tem-se a minimização da ocorrência dos pites instáveis, uma vez que a diminuição mais acentuada do pH impedirá sua passivação e o pite crescerá continuamente. Apenas a título de ilustração, foram medidos os $\mathrm{pH}$ dos eletrólitos utilizados no presente trabalho; os valores estão indicados na Tabela 7; nota-se que apesar de pouca diferença entre os valores, a tendência é a diminuição de pH com o aumento da concentração de brometo.

Tabela 7 - Valores de pH para os eletrólitos do presente trabalho.

\begin{tabular}{cc}
\hline ELETRÓLITO & pH \\
\hline $0,6 \mathrm{M} \mathrm{NaCl}$ & 6,1 \\
$0,45 \mathrm{M} \mathrm{NaCl}+0,15 \mathrm{M} \mathrm{NaBr}$ & 6 \\
$0,3 \mathrm{M} \mathrm{NaCl}+0,3 \mathrm{M} \mathrm{NaBr}$ & 6 \\
$0,6 \mathrm{M} \mathrm{NaBr}$ & 5,9 \\
\hline
\end{tabular}




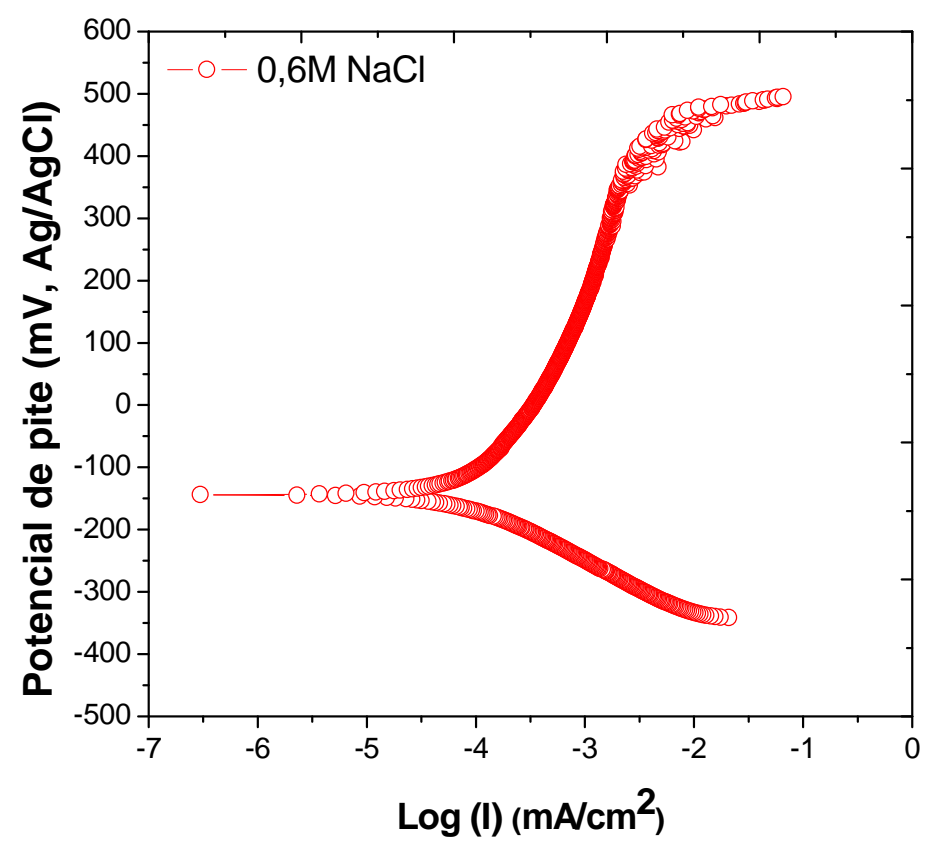

(a)

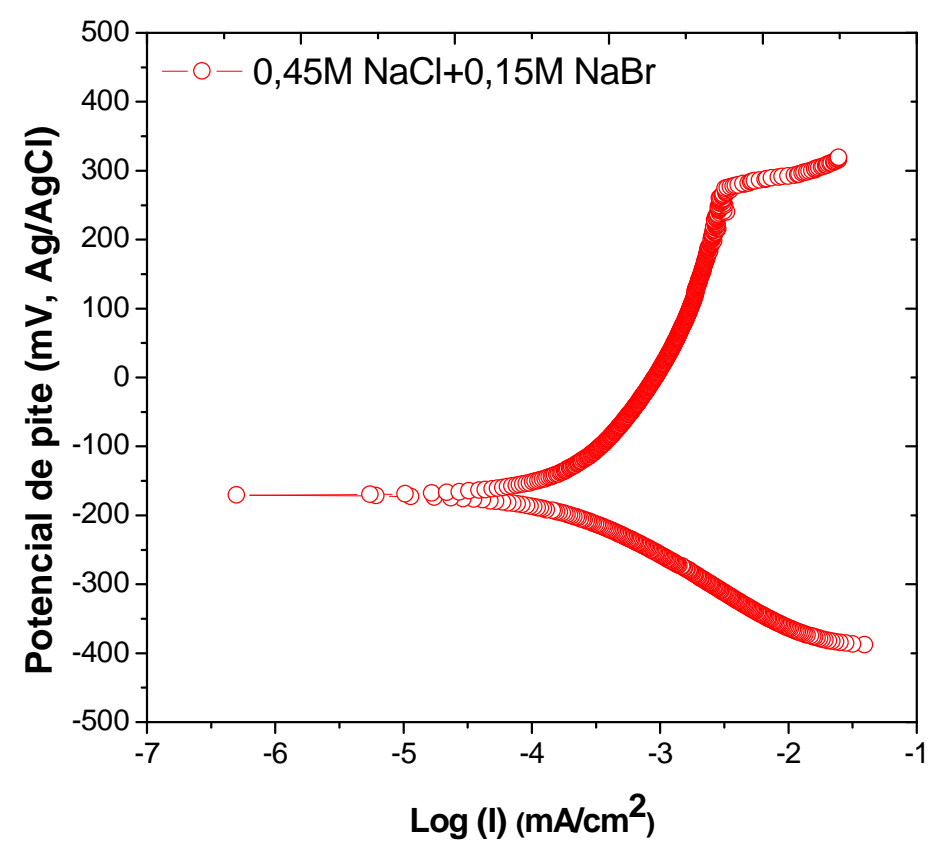

(b)

Figura 77. Curvas de polarização do aço inoxidável austenítico $316 \mathrm{~L}$. (a) $0,6 \mathrm{M} \mathrm{NaCl}$; (b) $0,45 \mathrm{M} \mathrm{NaCl}+0,15 \mathrm{M} \mathrm{NaBr}$. 


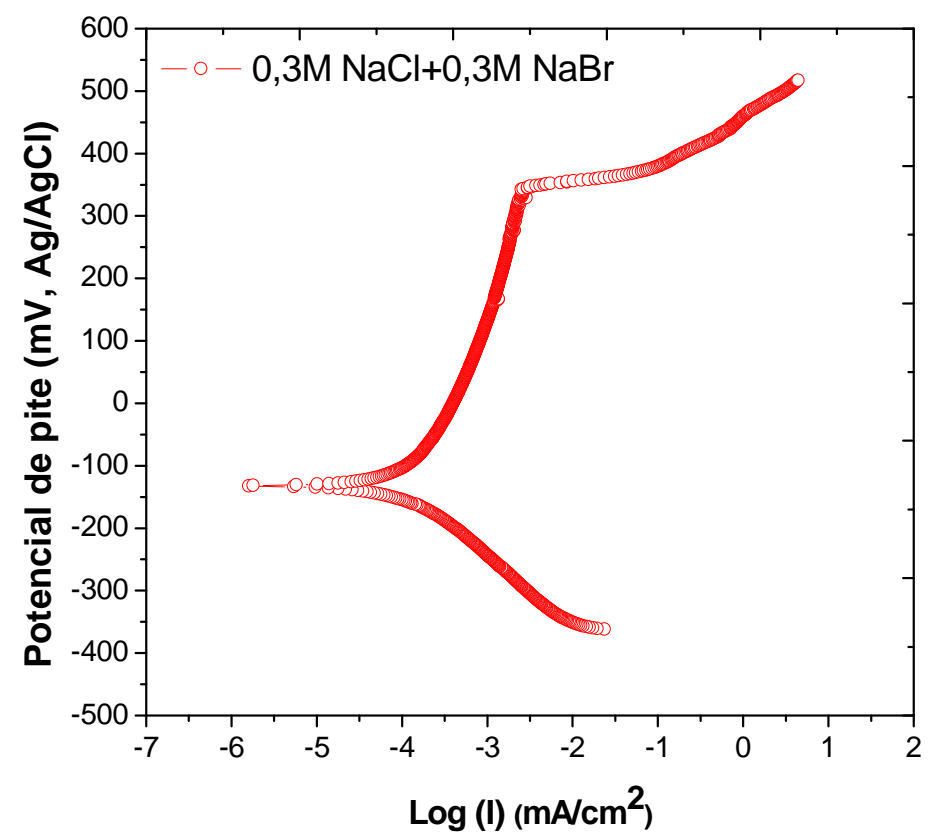

(a)

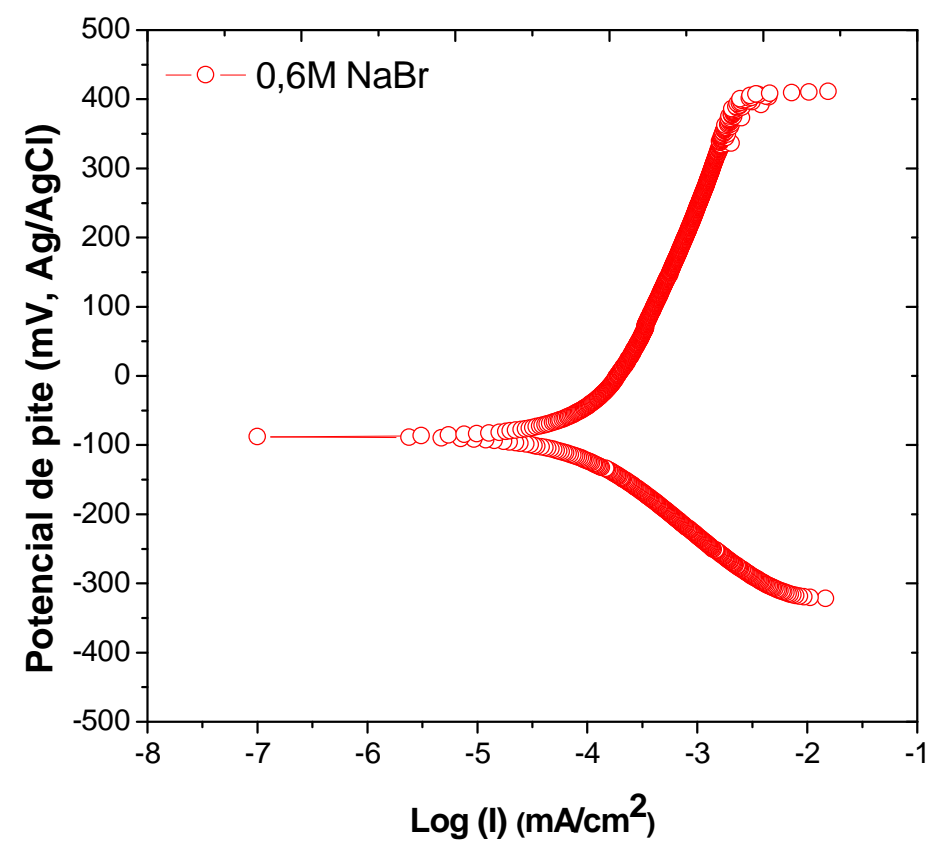

(b)

Figura 78. Curvas de polarização do aço inoxidável austenítico $316 \mathrm{~L}$. (a) $0,3 \mathrm{M} \mathrm{NaCl}+0,3 \mathrm{M}$ $\mathrm{NaBr}$ e (b) 0,6M NaBr. 


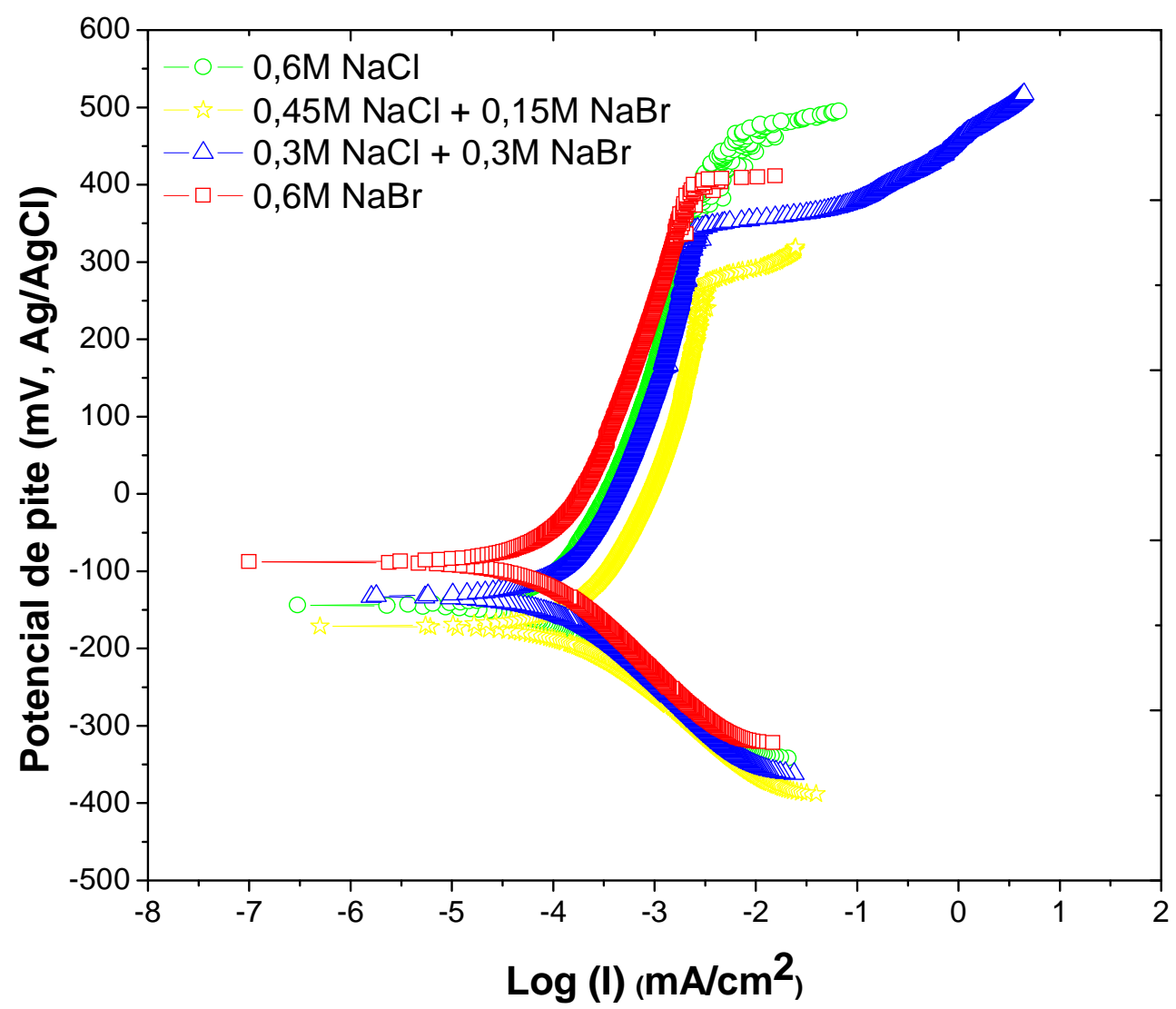

Figura 79 - Sobreposição das curvas de polarização do aço inoxidável austenítico 316L em meios cloreto, brometo e suas misturas.

\subsubsection{AÇO INOXIDAVEL FERRÍTICO 430}

As curvas de polarização para o aço inoxidável ferrítico 430 estão apresentadas nas Figura 80 e Figura 81, seguindo o mesmo modelo dos materiais anteriormente apresentados. Como nos casos anteriores, a forma da curva apresenta a definição do trecho catódico da reação de oxigênio, trecho passivo e potencial de pite. Nota-se, primeiramente, que este aço se caracterizou por apresentar fortes oscilações da densidade de corrente passiva (pites instáveis), principalmente para as soluções mais concentradas em cloreto. Este comportamento é semelhante ao observado para o aço 304 e $316 \mathrm{~L}$, valendo aqui as mesmas considerações mencionadas acima.

Através da Figura 82 é possível observar que o aço 430 é muito sensível às diferenças de composição química do eletrólito: os valores de Ep são bem 
distintos para cada eletrólito. Essa figura, já mostra que na medida em que se aumenta o teor de cloreto no eletrólito, em detrimento do teor de brometo, a resistência à corrosão por pite diminui significativamente. Os valores médios de Ep para cada concentração estão apresentados mais adiante, onde é possível observar mais claramente estas diferenças.

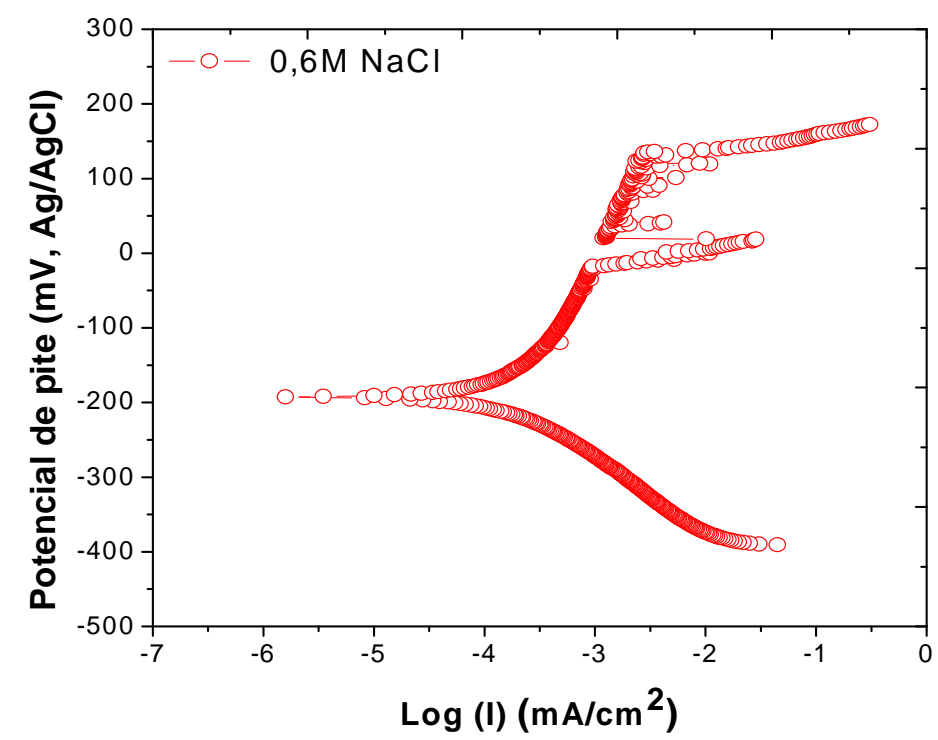

(a)

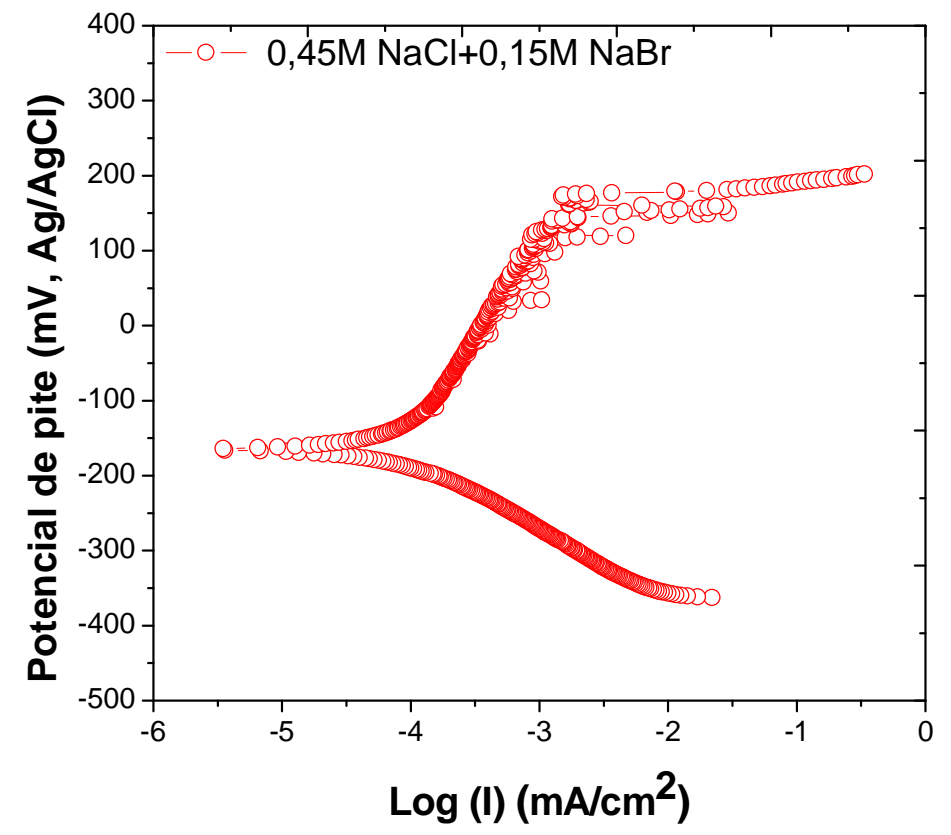

(b)

Figura 80. Curvas de polarização do aço inoxidável ferrítico 430 . (a) $0,6 \mathrm{M} \mathrm{NaCl}$ e (b) $0,45 \mathrm{M} \mathrm{NaCl}+0,15 \mathrm{M} \mathrm{NaBr}$. 


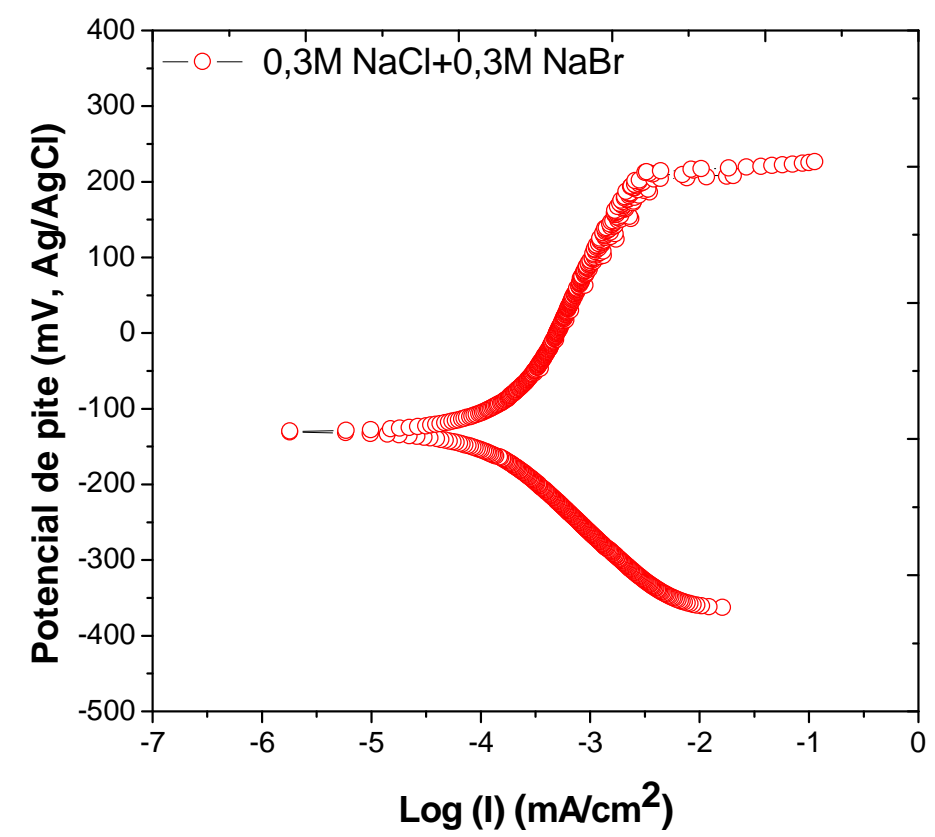

(a)

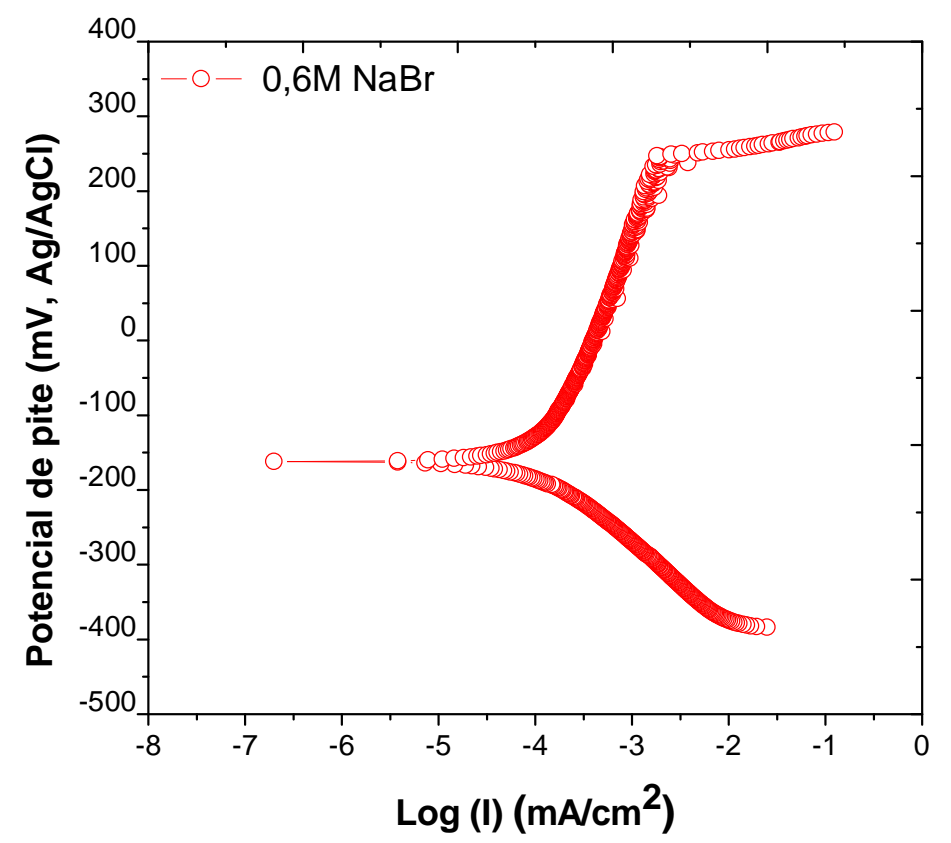

(b)

Figura 81. Curvas de polarização do aço inoxidável ferrítico 430 . (a) $0,3 \mathrm{M} \mathrm{NaCl}+0,3 \mathrm{M} \mathrm{NaBr}$ e (b) $0,6 \mathrm{M} \mathrm{NaBr}$. 


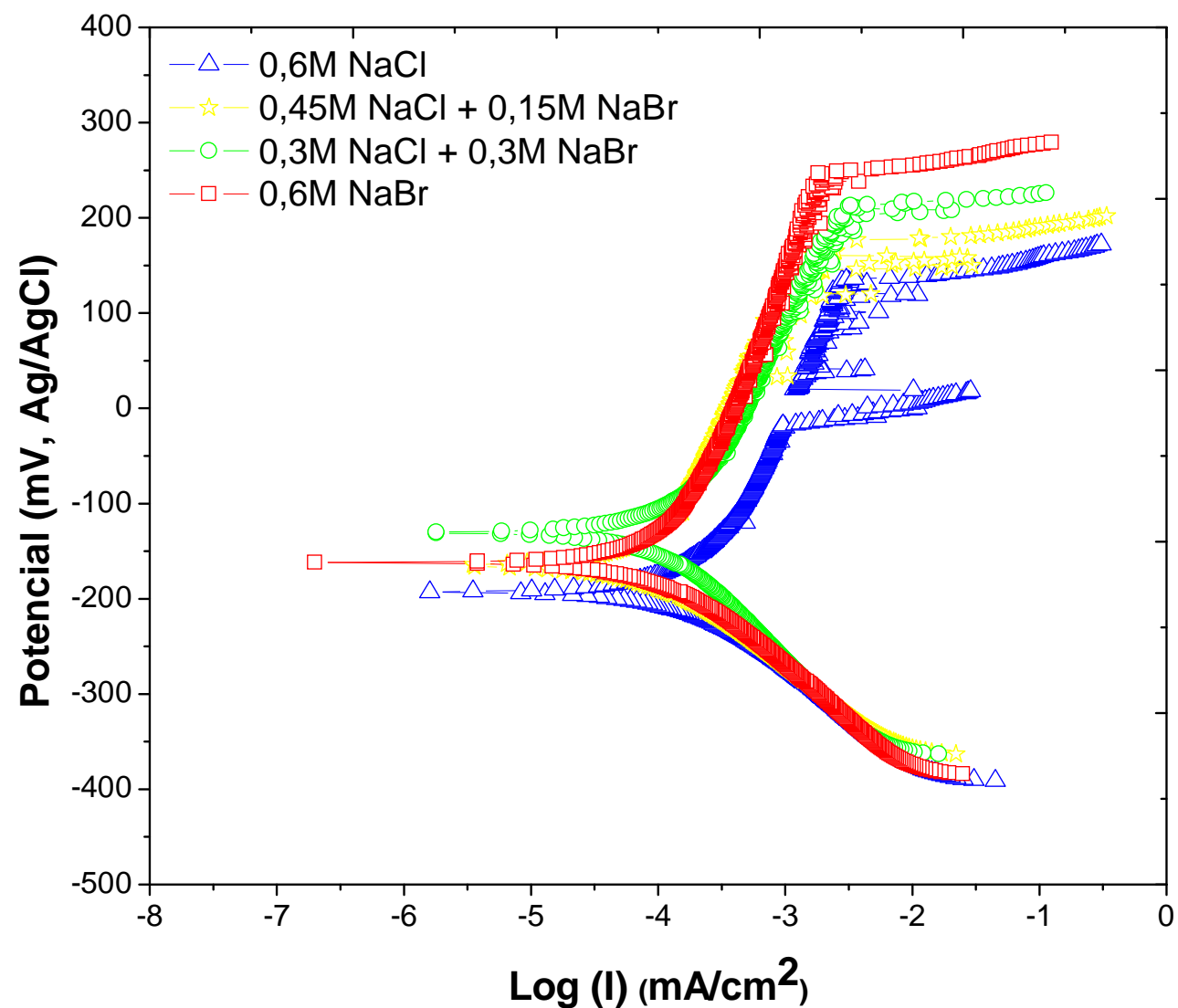

Figura 82. Sobreposição das curvas de polarização do aço inoxidável ferrítico 430 em meios contendo cloreto, brometo e suas misturas.

\subsubsection{AÇO INOXIDAVEL FERRÍTICO 444}

Igualmente aos casos anteriores, as Figura 83 e Figura 84 apresentam as curvas de polarização para o aço inoxidável ferrítico 444. Observa-se que as curvas de polarização se caracterizaram por não apresentarem oscilações da densidade de corrente passiva, ou seja, caracterizaram-se pela ausência de pites instáveis. Aparentemente, o efeito do ácido bromídrico, sobre a nucleação de pites de crescimento contínuo, não é o único fator que explica a ausência de pites instáveis para o caso do aço 444. Lembrando que o aço 444 contém como elementos de liga $\mathrm{Ti}, \mathrm{Nb}$ e $\mathrm{Mo}$, e não contém $\mathrm{Ni}$, pode-se tentar encontrar uma explicação a partir dessa composição química diferenciada. Primeiramente, como no caso do aço $316 \mathrm{~L}$, é provável que a ausência de pites instáveis, esteja relacionada aos efeitos benéficos do Mo na repassivação de pites. No entanto, apenas a adição de Mo não explica a total ausência de pites 
instáveis, uma vez que o aço $316 \mathrm{~L}$ apresentou tais pites para o eletrólito de $0,6 \mathrm{M} \mathrm{NaCl}$. Resta, então, supor que os elementos $\mathrm{Ti}+\mathrm{Nb}$ e a própria ausência de Ni sejam responsáveis pela não ocorrência de pites instáveis.

Por sua vez, a Figura 85 mostra que este material foi pouco sensível às diferenças de composição química dos eletrólitos e que o pior desempenho quanto ao Ep foi obtido para o eletrólito rico em $\mathrm{NaCl}(0,6 \mathrm{M} \mathrm{NaCl})$.

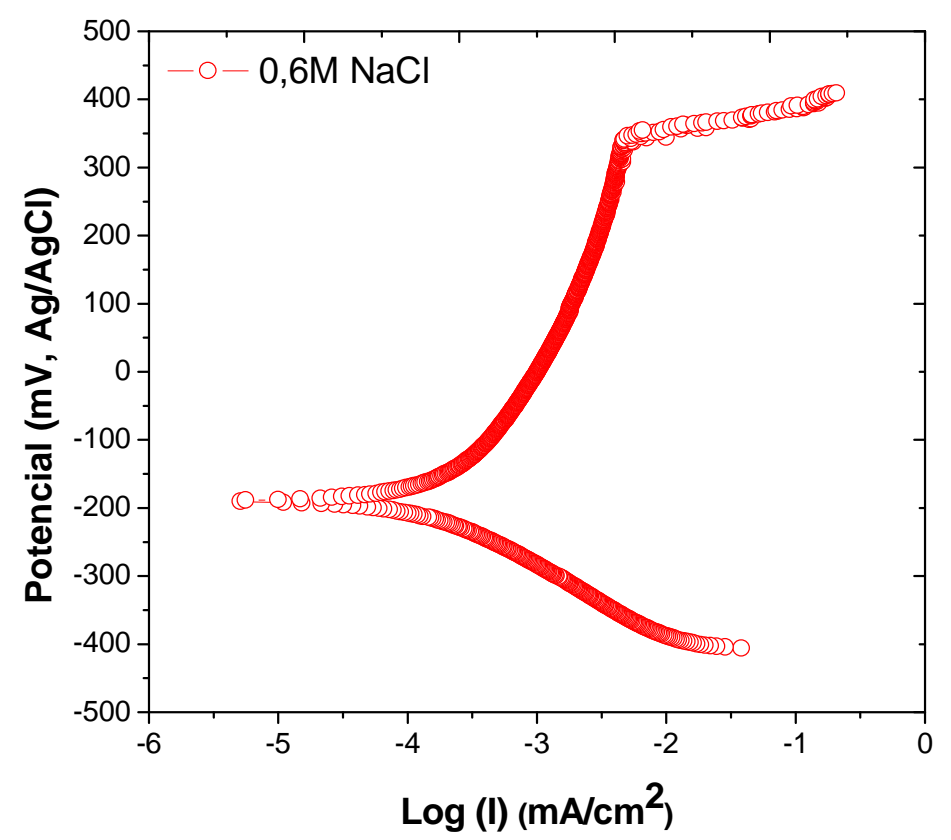

(a) 


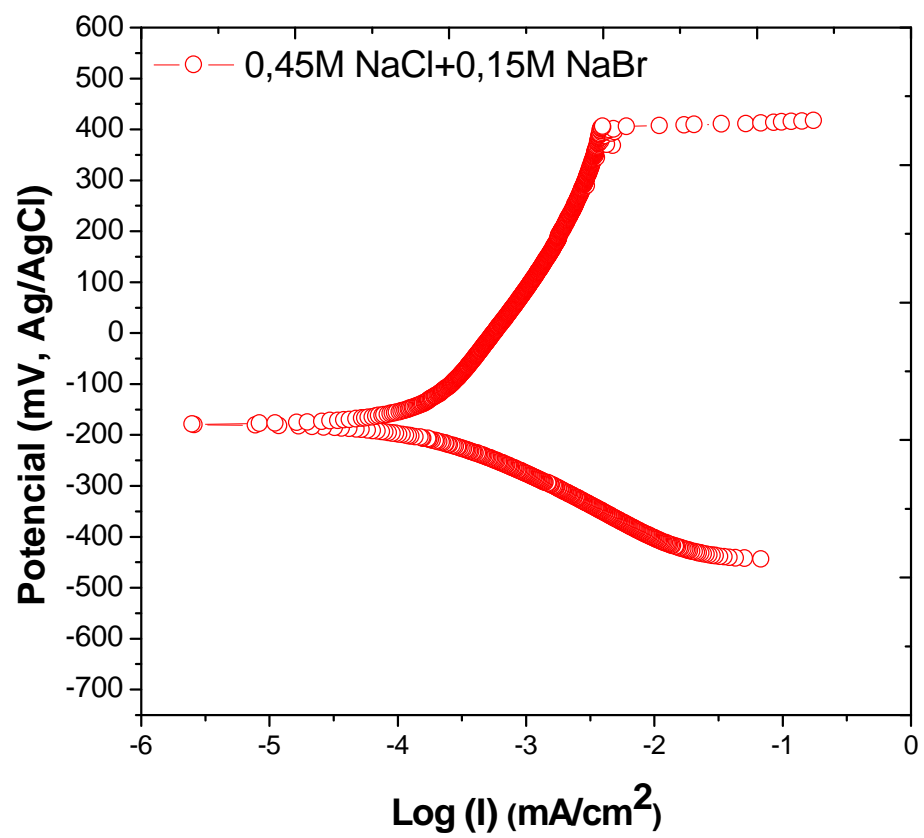

(b)

Figura 83. Curvas de polarização potenciodinâmica do aço 444 . (a) $0,6 \mathrm{M} \mathrm{NaCl}$ e (b) $0,45 \mathrm{M}$ $\mathrm{NaCl}+0,15 \mathrm{M} \mathrm{NaBr}$.

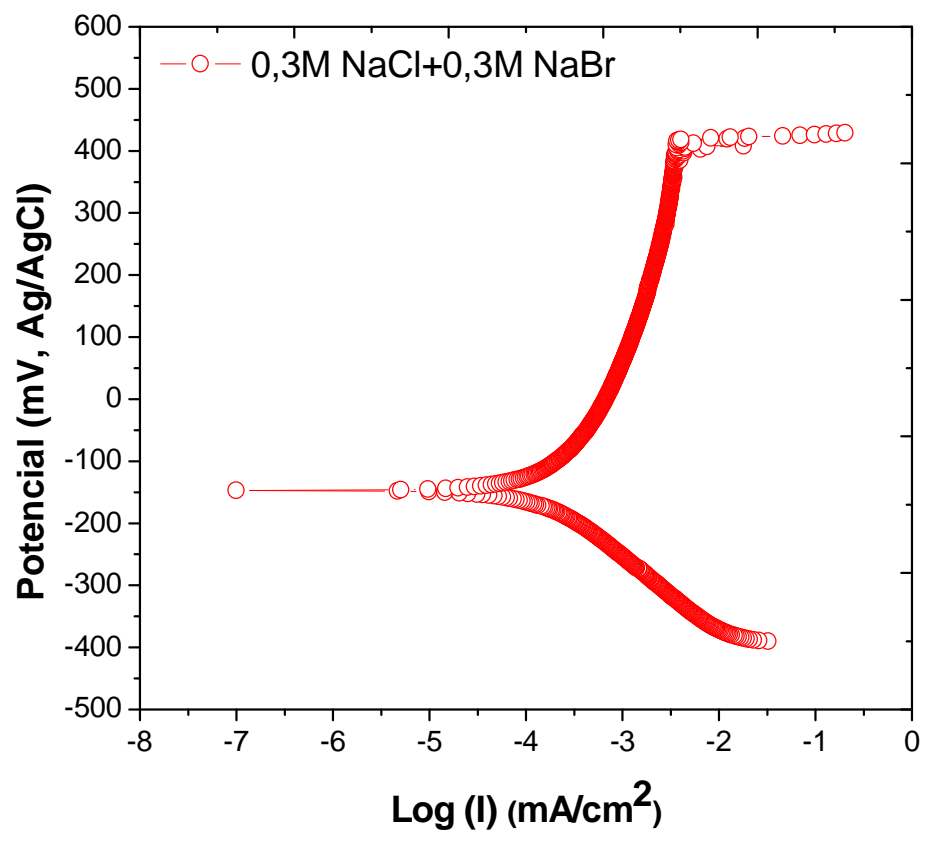

(a) 


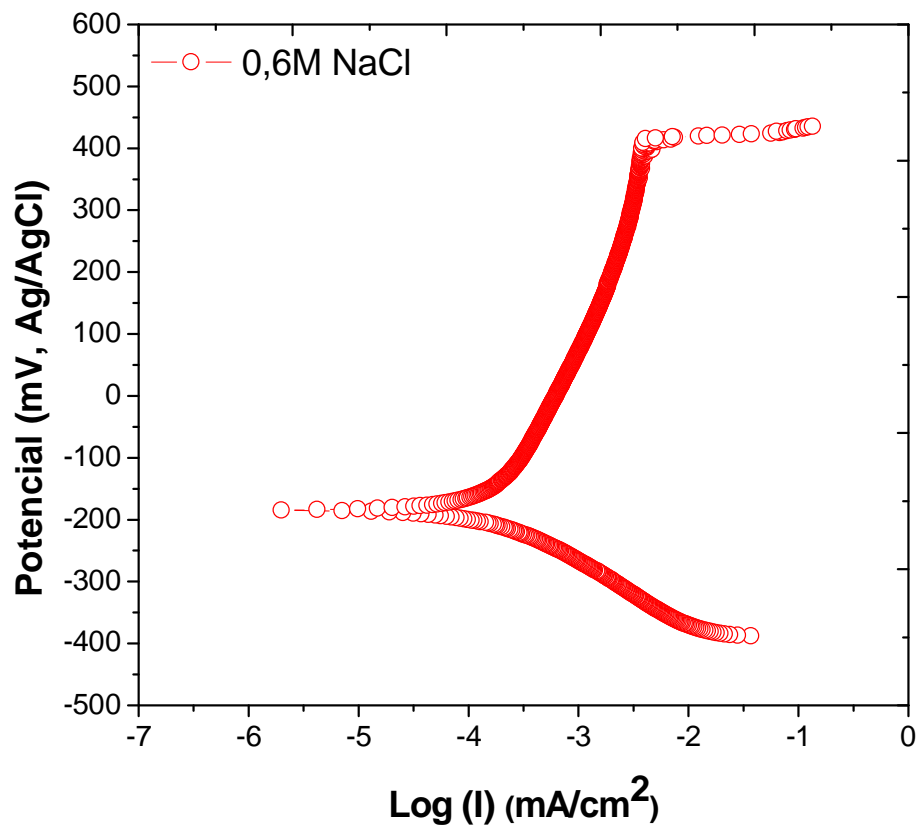

(b)

Figura 84. Curvas de polarização do aço inoxidável ferrítico 444. (a) $0,3 \mathrm{M} \mathrm{NaCl}+0,3 \mathrm{M} \mathrm{NaBr}$ e (b) $0,6 \mathrm{M} \mathrm{NaBr}$.

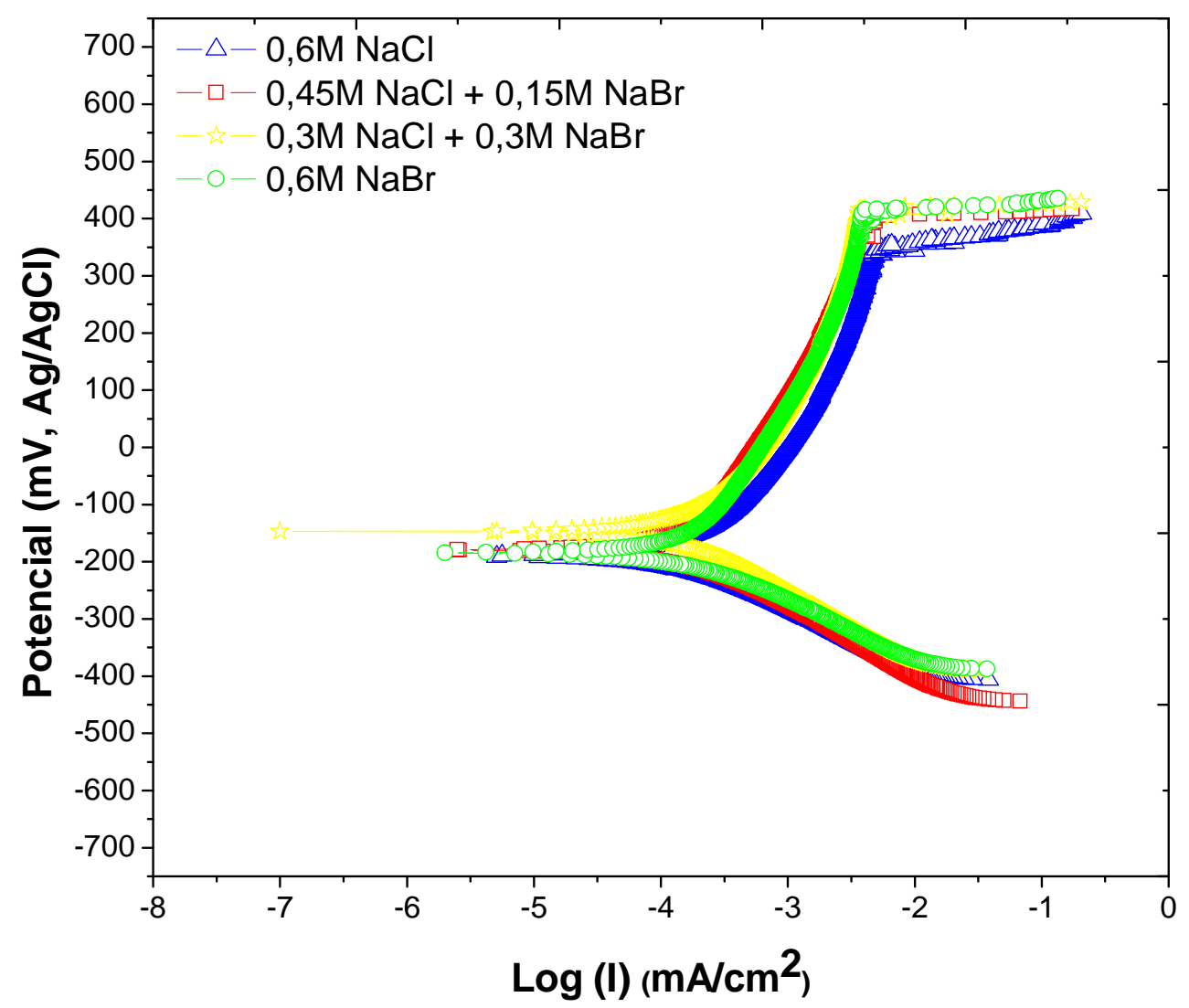

Figura 85. Sobreposição das curvas de polarização do aço inoxidável ferrítico 444 em meios contendo cloreto, brometo e suas misturas. 


\subsection{EXAMES DA NUCLEAÇÃO DOS PITES: SítIOS E MORFOLOGIAS}

\subsubsection{SITIOS DE NUCLEAÇÃO DOS PITES}

Os sítios de nucleação de pites são de grande importância, já que eles controlam, de certa forma, a resistência à corrosão destes materiais. Para encontrar estes sítios o ensaio de polarização potenciodinâmica foi interrompido numa densidade de corrente menor do que aquela utilizada para a determinação do potencial de pite propriamente dito, de modo que o pite nucleado não atingisse um tamanho que prejudicasse a identificação do sítio de nucleação. A polarização foi interrompida quando era atingida a densidade de corrente de $10^{-5} \mathrm{~A} / \mathrm{cm}^{2}$. O acabamento de superfície utilizado nesta etapa foi o de lixa \#1200. Optou-se por esta condição, para tentar reproduzir a superfície utilizada na determinação do Ep (lixa \#600), mas, com um nível melhor de acabamento, de modo a permitir a observação de inclusões ou outros tipos de defeitos que poderiam originar pites.

A superfície ensaiada foi examinada em MEV visando obter indícios que possam clarificar quais foram os primeiros sítios onde nuclearam os pites. Quando encontrados resíduos de corrosão foram feitas análises por EDS para identificar detalhes destes produtos.

Devido às dificuldades inerentes a este tipo de pesquisa, restringiu-se a busca dos sítios de nucleação de pites para os eletrólitos puros: $0,6 \mathrm{M} \mathrm{NaCl}$ e $0,6 \mathrm{M} \mathrm{NaBr}$.

\subsubsection{AÇO INOXIDÁVEL AUSTENÍTICO 298}

\section{- ELETRÓLITO DE 0,6M NaCl}

A Figura 86 apresenta um pite nucleado em inclusão, a qual não mostra sinais de dissolução. Para determinar a composição química desta inclusão 
foram realizadas análises por EDS (Figura 87). No ponto 1 observa-se que a inclusão apresenta $\mathrm{Si}$, indicando assim que se trata de um óxido Si.

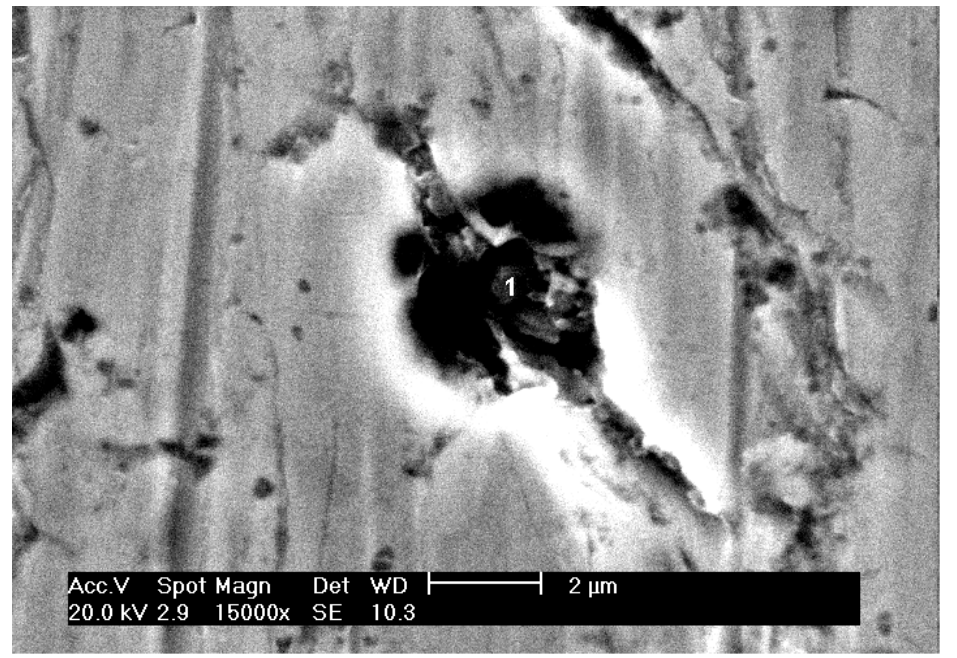

Figura 86 - Pite nucleado em inclusão (ponto 1). Aço 298 em 0,6M NaCl. Imagem de elétrons secundários e aumento de 15000x.

1

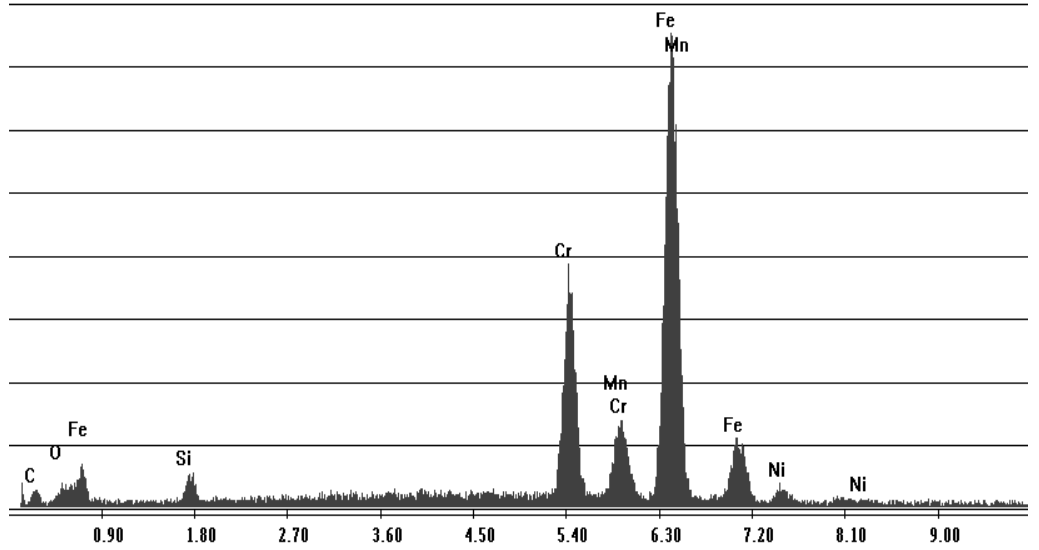

(a) 


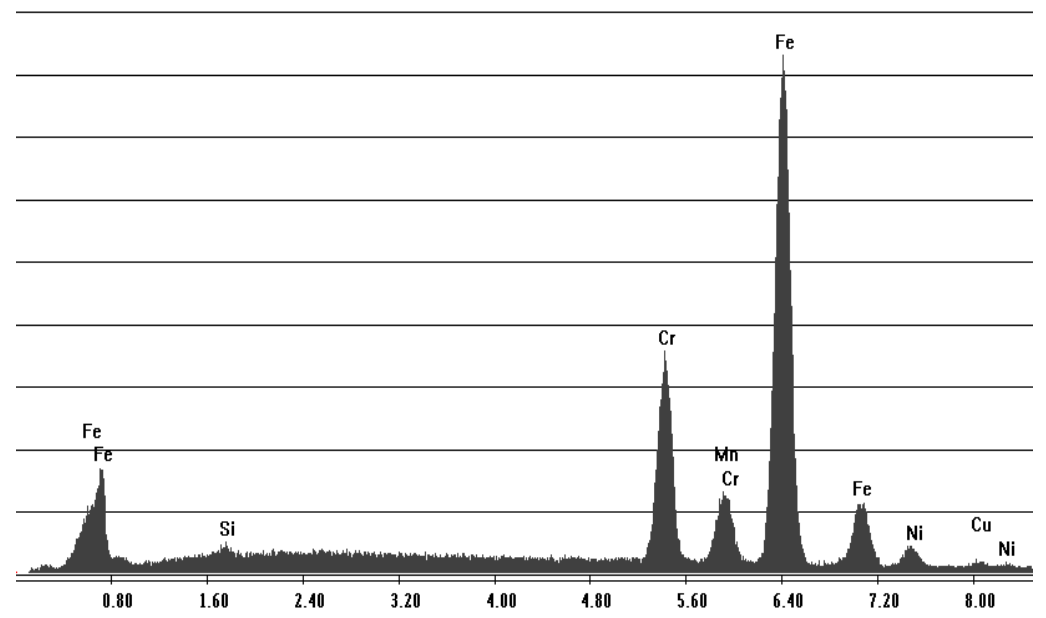

(b)

Figura 87 - Espectros das análises por EDS. (a) Inclusão: ponto 1 e (b) matriz: para efeito de comparação.

Um mecanismo foi proposto por Baker e Castle(65) para tentar explicar o fenômeno pelo qual ocorre a dissolução da interface matriz/inclusão de óxido causada pelo ataque dos íons agressivos. Segundo Baker e Castle(65) a dissolução da interface (matriz/inclusão de óxido) está baseada na formação de uma microfresta (Figura 88) formada entre os átomos do metal, da inclusão e do filme passivo.

Segundo Baker e Castle(65) e outros autores(42) há uma diferença de potencial elétrico entre o metal (região 1 da Figura 88) e o eletrólito que provoca a atração dos íons agressivos para essa região (Figura 88), que é a microfresta. É importante ressaltar que este mecanismo é válido exclusivamente para as inclusões eletricamente inertes (óxidos), e lembrar que inclusões de sulfetos são eletricamente mais condutoras do que a película passiva(66), fazendo com que o processo eletroquímico ocorra através delas. 


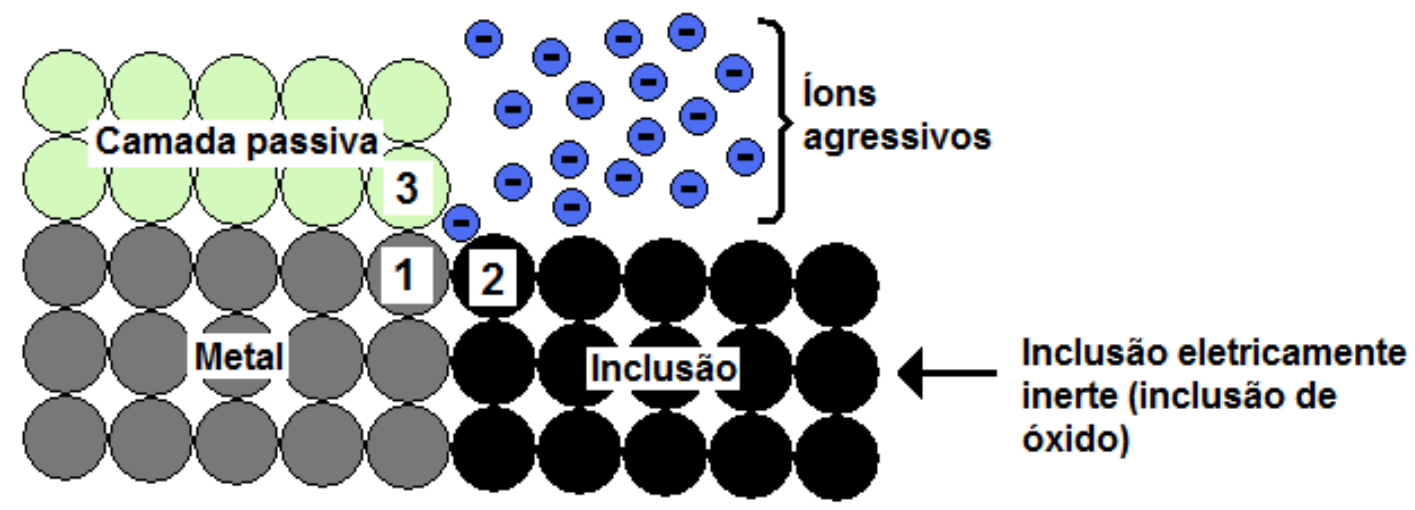

Figura 88 - Representação esquemática do mecanismo da dissolução da interface matriz/inclusão de óxido(65). A microfresta é o ângulo formado entre os pontos $3,1 \mathrm{e}$ 2. Modificado.

De fato, tem-se uma evidência desse mecanismo na Figura 89(a) que mostra, claramente, a precipitação de $\mathrm{NaCl}$ na interface matriz/inclusão de óxido de Al. Observa-se que o sal nucleou e cresceu a partir da interface, indicando que íons cloreto estavam acumulados nessa região.

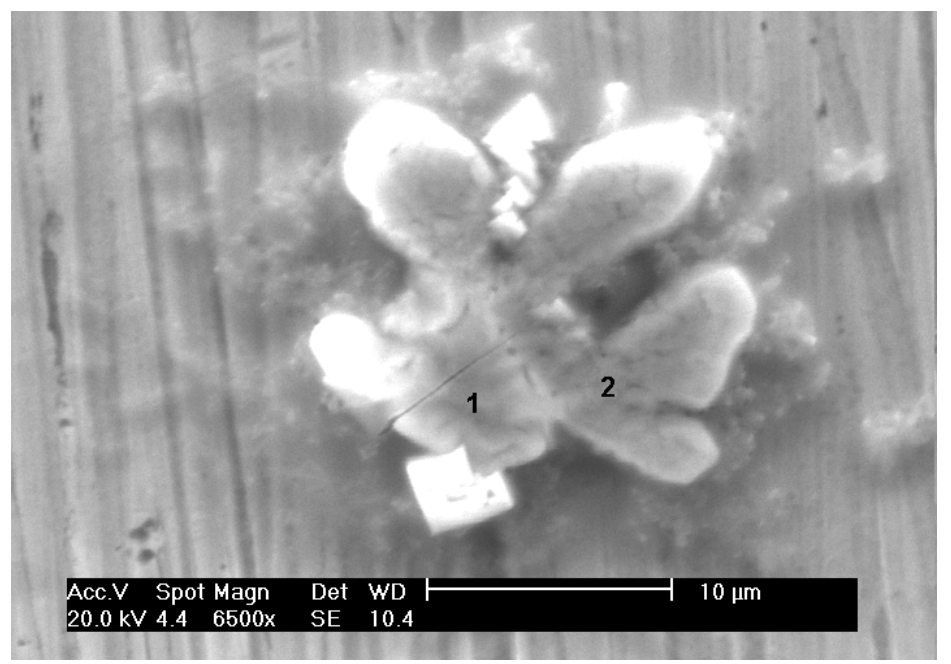

(a) 


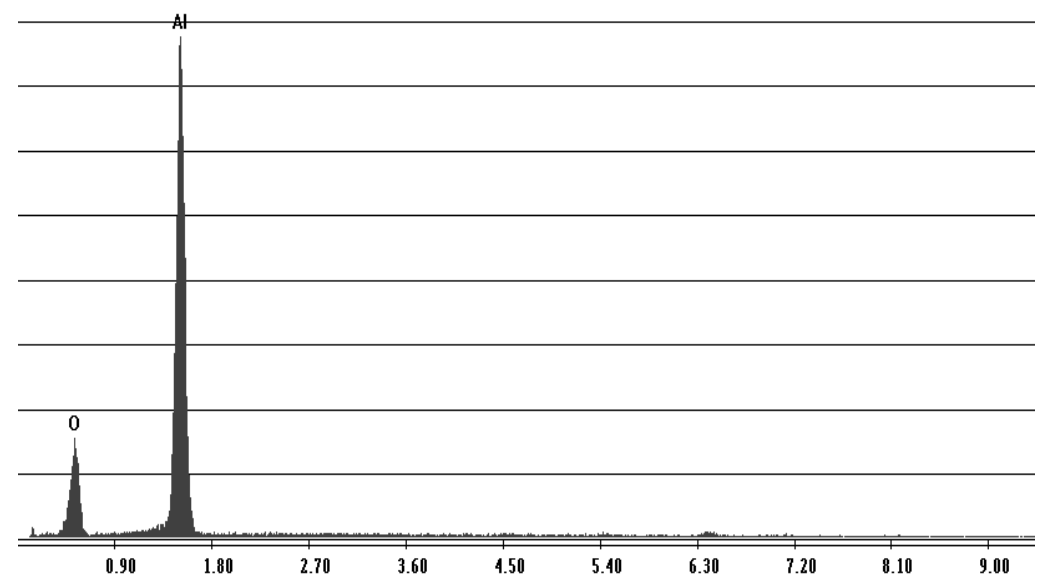

(b)

2

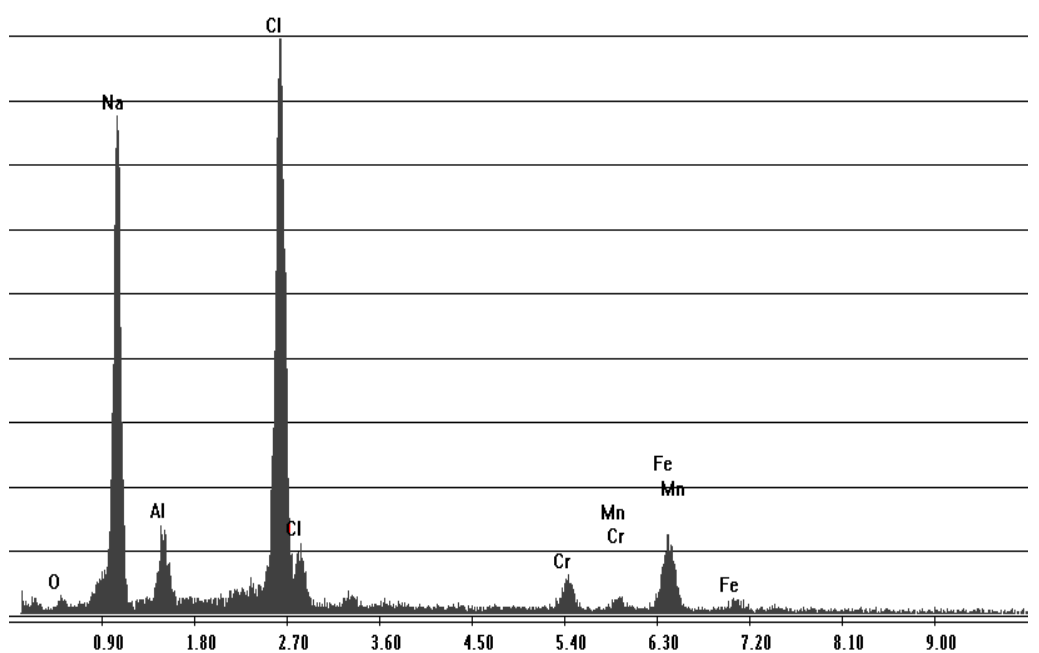

(c)

Figura 89 - Exemplo de precipitação de sal de $\mathrm{Cl}^{-}(\mathrm{NaCl})$ na interface de uma inclusão de óxido alumínio. (a) Imagem de elétrons secundários. (b) Espectro da análise por EDS da inclusão (ponto 1) e (c) espectro da análise por EDS do sal precipitado.

\section{- ELETRÓLITO DE 0,6M NaBr}

Na Figura 90 se exibe a nucleação de um pite em uma inclusão. Analogamente ao caso anterior, a inclusão não foi dissolvida durante 0 processo de corrosão, e a nucleação do pite ocorreu mediante a dissolução da interface matriz/inclusão. O resultado da análise por EDS (Figura 91) mostra 
que se trata de inclusão de óxido de Al e Si. Tem-se, então, que o modelo de Baker e Castle(65) também é válido para os eletrólitos de $\mathrm{NaBr}$.

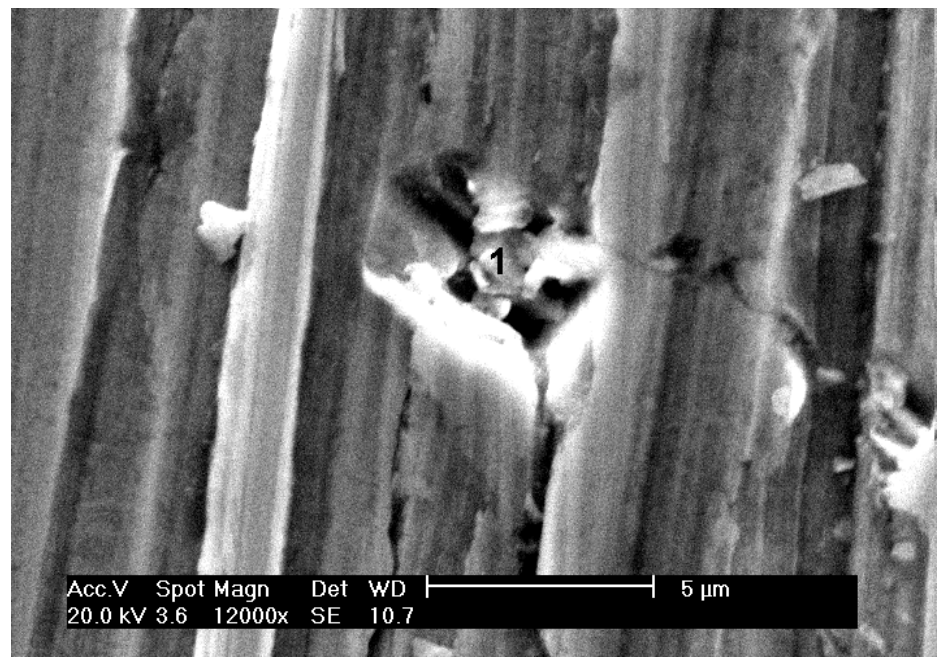

Figura 90 - Pite nucleado na interface matriz/inclusão (ponto 1). Aço 298 em 0,6M NaBr. Imagem de elétrons secundários e aumento de 12000x.

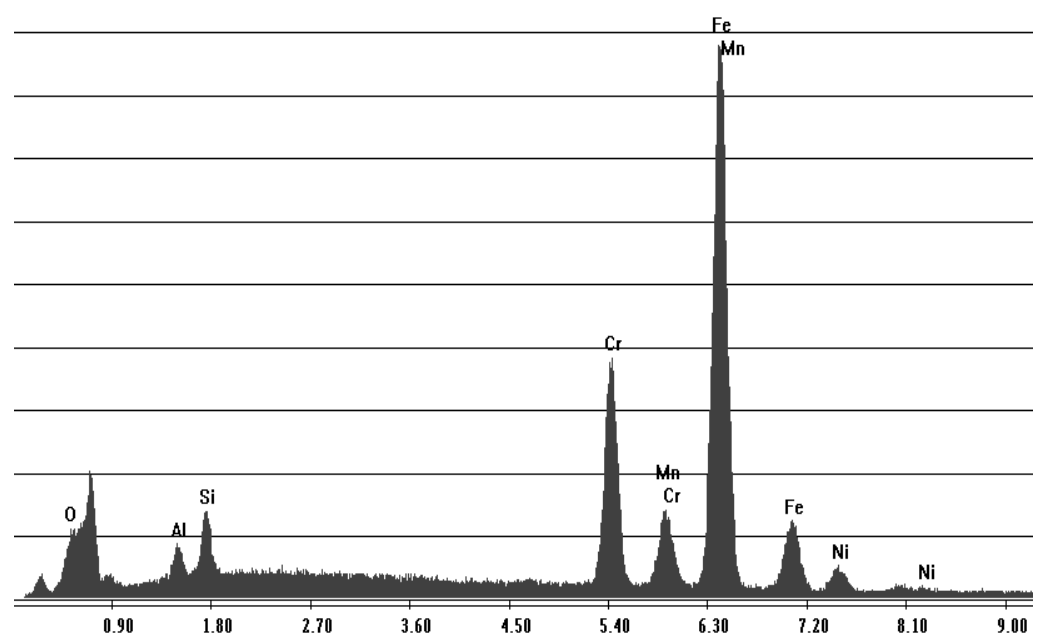

(a) 


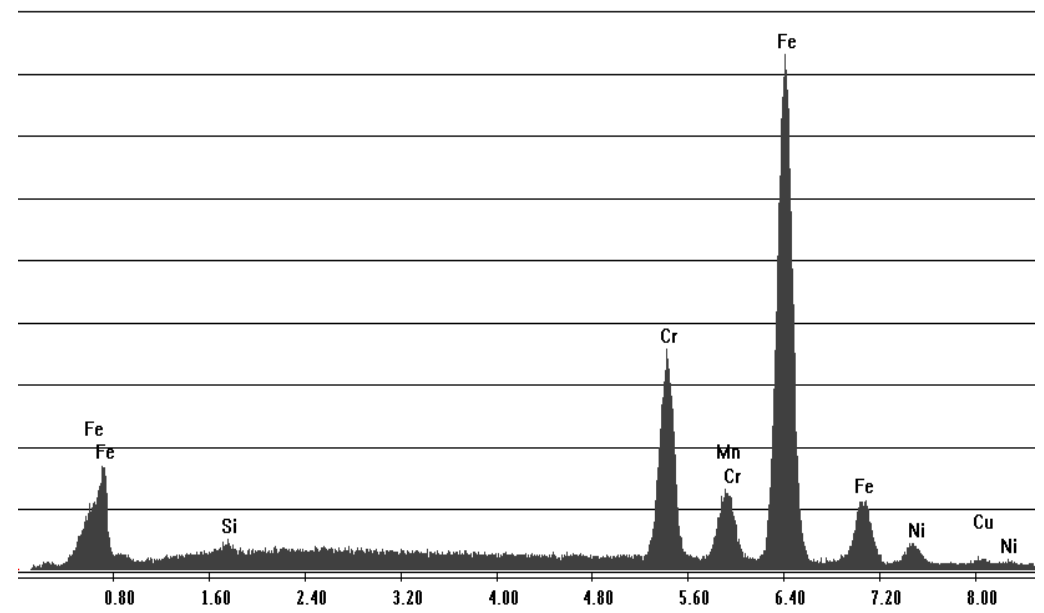

(b)

Figura 91 - Espectros da análise por EDS. (a) Inclusão: ponto 1 e (b) matriz: para efeito de comparação.

\subsubsection{AÇO INOXIDÁVEL AUSTENÍTICO 304}

\section{- $\quad$ ELETRÓLITO DE 0,6M NaCl}

Para este aço, foram encontrados dois pites apresentados na Figura 92. Observa-se que há um resíduo no fundo do pite nos dois casos. A análise por EDS desses resíduos (Figura 93) mostra elevados teores altos de $\mathrm{S}$ e Ba, e em menor porcentagem Si. Pode-se concluir, a partir disso, que ocorreu a nucleação dos pites a partir da interface matriz/inclusão ou a partir da dissolução da inclusão de sulfeto. De fato, as inclusões de sulfeto são mencionadas como sítios que favorecem a nucleação de pites, a partir de sua própria dissolução(63). 


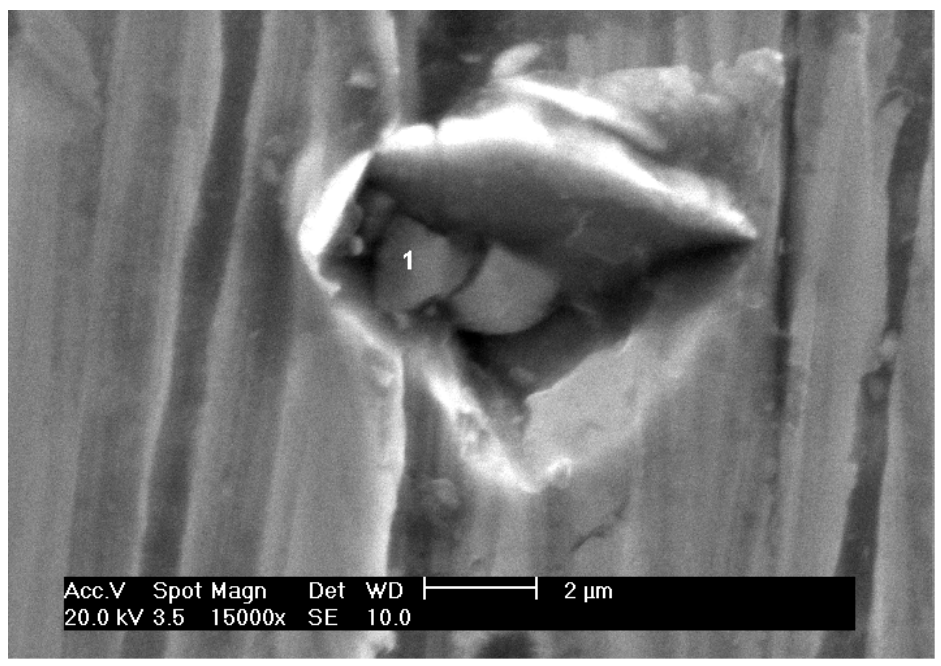

(a)

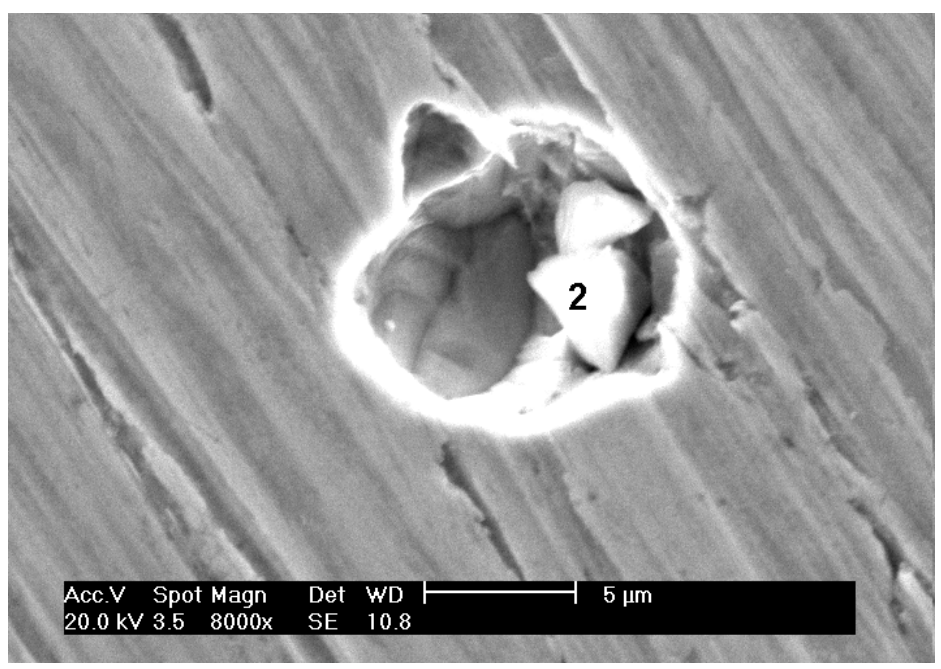

(b)

Figura 92 - Pites contendo um residual de inclusão (ponto 1 e ponto 2). Aço 304 em 0,6M NaCl. Imagem de elétrons secundários e aumento de 15000x. 


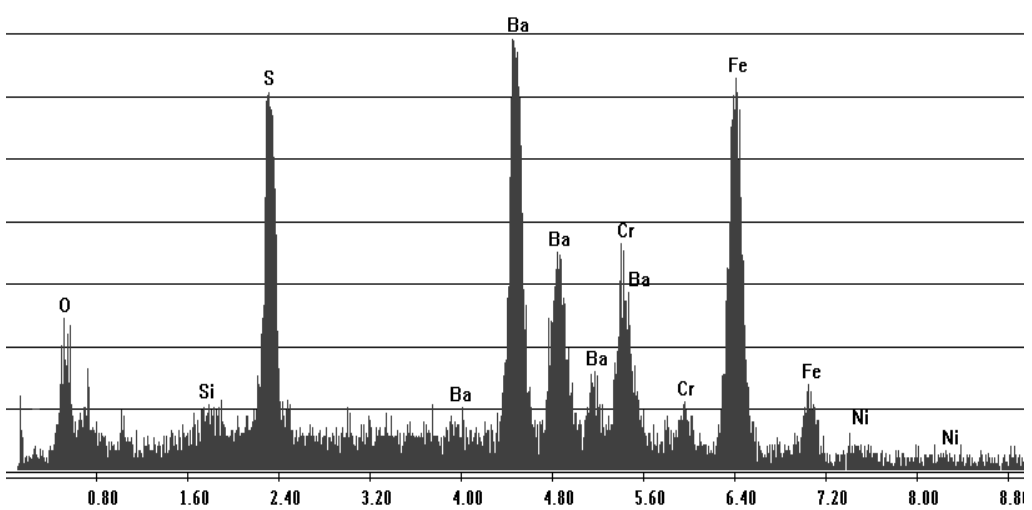

Figura 93 - Espectro da análise por EDS no resíduo encontrado no fundo dos pites (inclusão): notam-se elevados teores de $\mathrm{Ba}$ e $\mathrm{S}$, e em menor porcentagem Si. Cabe ressaltar que os teores de $\mathrm{Cr}$, $\mathrm{Fe}$ e $\mathrm{Ni}$ correspondem à matriz. Este espectro foi realizado para o ponto $1 \mathrm{da}$ Figura 92; a análise para o ponto 2 apresentou o mesmo resultado.

Existem algumas hipóteses sobre como as inclusões de sulfeto influenciam sobre a iniciação do pite. Tronstad e Sejsted(67) acreditam que quando há inclusões de sulfeto, o ataque dos ions agressivos começa, como regra geral, na interface matriz/inclusão. Eles presumiram que a destruição da película passiva pode ser causada como resultado das diferenças nos coeficientes de expansão térmica da matriz e da inclusão, ou possivelmente devido a uma fraca coesão interfacial(67), que pode dar como resultado disso, a formação de uma microfresta na interface.

Por outro lado, Wranglen(63) sugeriu que, devido à elevada condutividade eletrônica das inclusões de sulfeto comparado com o filme passivo, os íons agressivos são seletivamente adsorvidos na superfície da inclusão, facilitando assim a sua dissolução anódica.

Mais adiante, levantam-se algumas hipóteses sobre a presença de Ba e $\mathrm{S}$ no interior destes e de outros pites 
Da mesma maneira que aço 298, a nucleação de um pite (Figura 94) ocorre em uma inclusão que não tem sinais de ter sido dissolvida durante o processo de corrosão. Vale a pena ressaltar que a nucleação do pite ocorreu pela dissolução da interface, mediante o mecanismo que foi explicado anteriormente (Figura 88). O resultado da análise por EDS realizada na inclusão (Figura 95) mostra Al na sua composição química, o que indica se tratar de um óxido de Al.

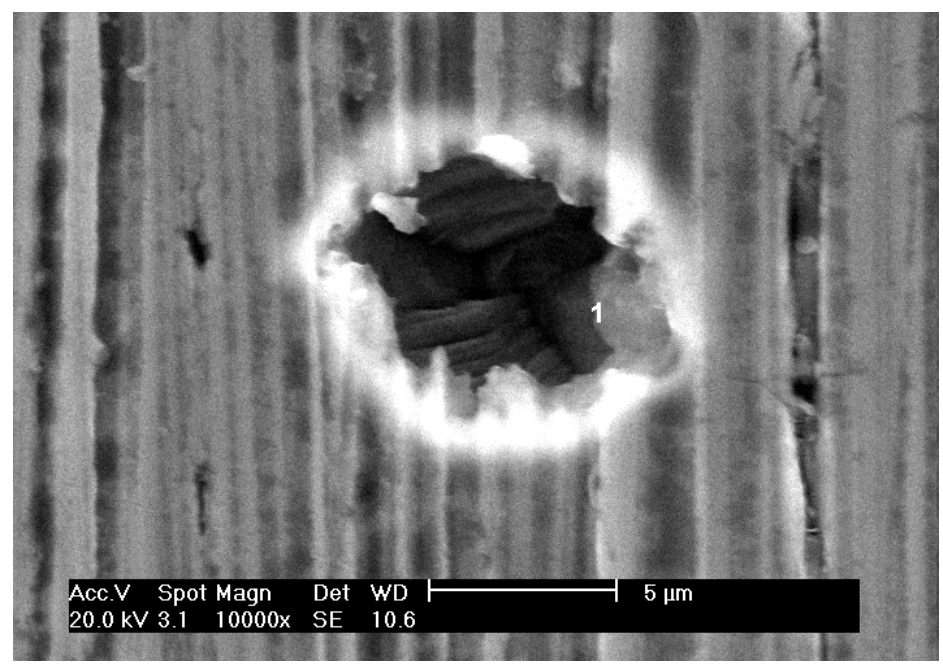

Figura 94 - Pite nucleado em interface de inclusão (ponto 1). Aço 304 em 0,6M NaBr. Imagem de elétrons secundários e aumento de 10000x. 


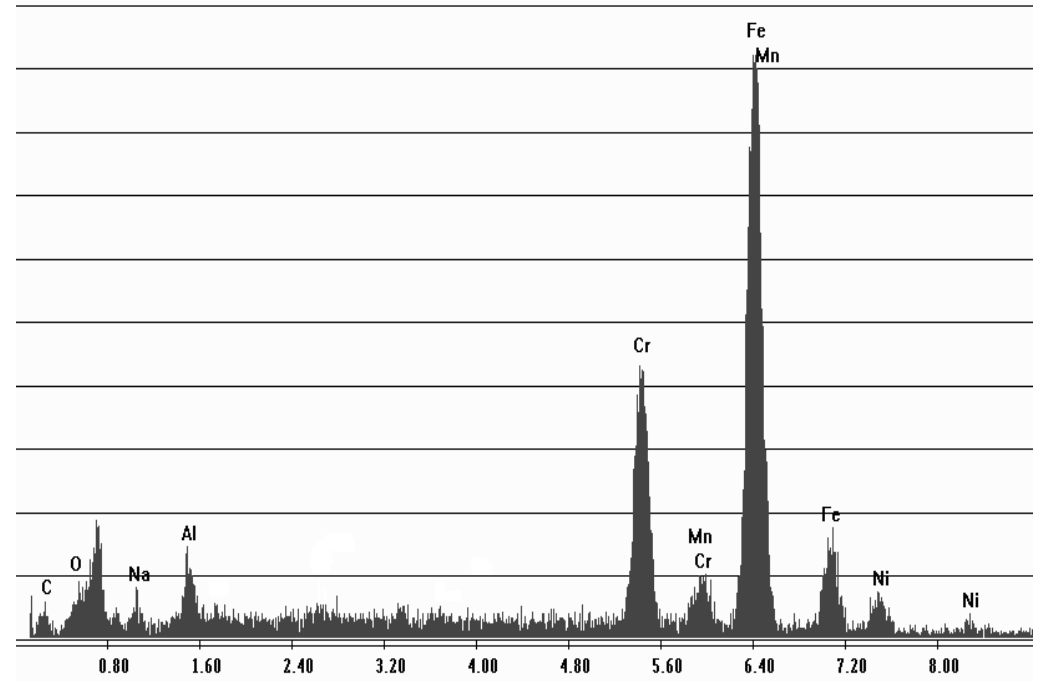

(a)

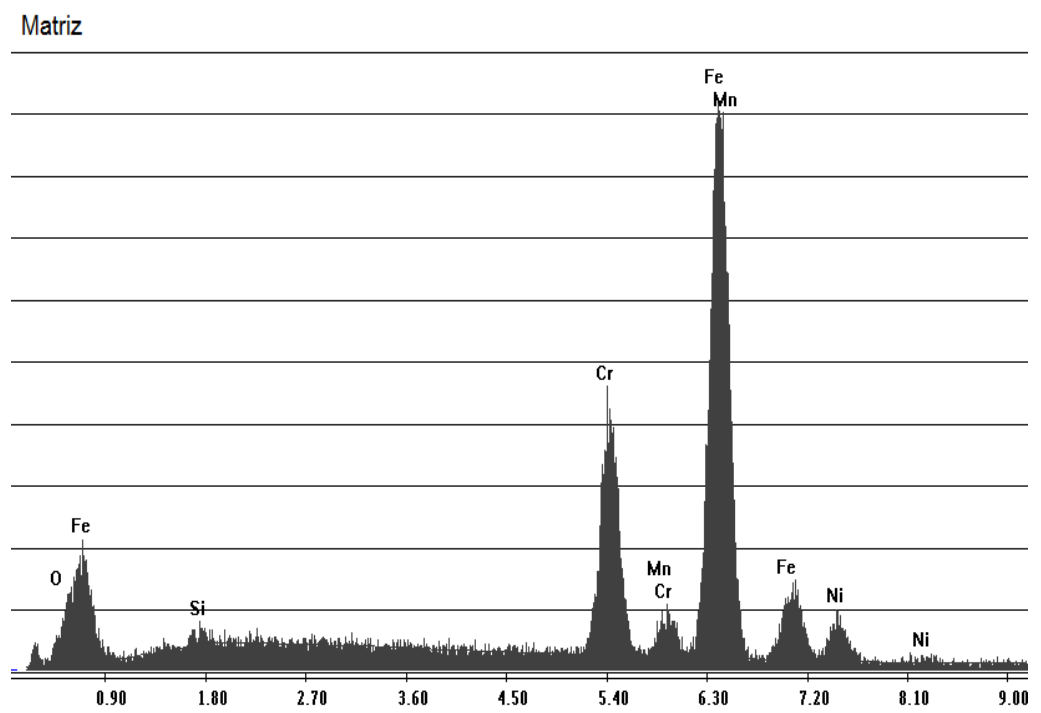

(b)

Figura 95 - Espectros da análise por EDS. (a) Inclusão (ponto 1): nota-se a presença de Al. Cabe ressaltar que os teores de $\mathrm{Cr}$, $\mathrm{Fe}$ e Ni correspondem à matriz, e (b) matriz: para efeito de comparação.

\subsubsection{AÇO INOXIDÁVEL AUSTENÍTICO 316L}

\section{- $\quad$ ELETRÓLITO DE 0,6M NaCl}

Analogamente aos casos anteriores, mostra-se a nucleação de um pite em uma inclusão (Figura 96). Nota-se a presença de resíduos no fundo do pite, 
os quais podem corresponder à dissolução de uma inclusão durante o processo de corrosão, do mesmo modo que ocorreu para o aço 304 em 0,6M $\mathrm{NaCl}$.

O resultado da análise por EDS (Figura 97) realizada no resíduo mostra elevados teores de $\mathrm{S}$ e $\mathrm{Ba}$, e em menor porcentagem o $\mathrm{Si}$, o que permite concluir que esta inclusão complexa está composta, eventualmente, por um sulfeto de Ba e um óxido de Si, como no caso do aço 304.

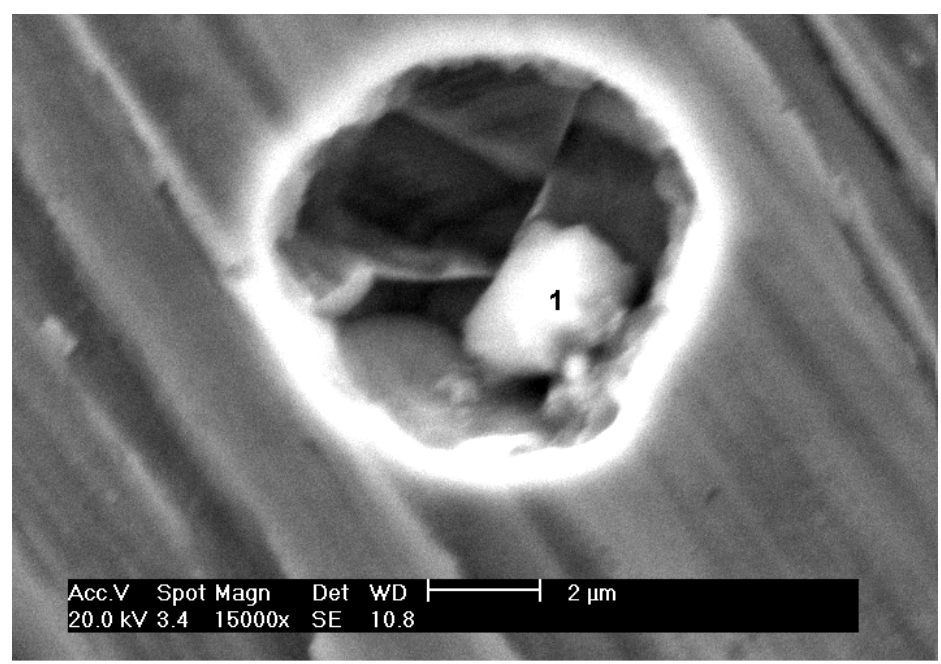

Figura 96 - Pite contendo um residual de inclusão (ponto 1). Aço 316L em 0,6M NaCl. Imagem de elétrons secundários e aumento de 15000x

1

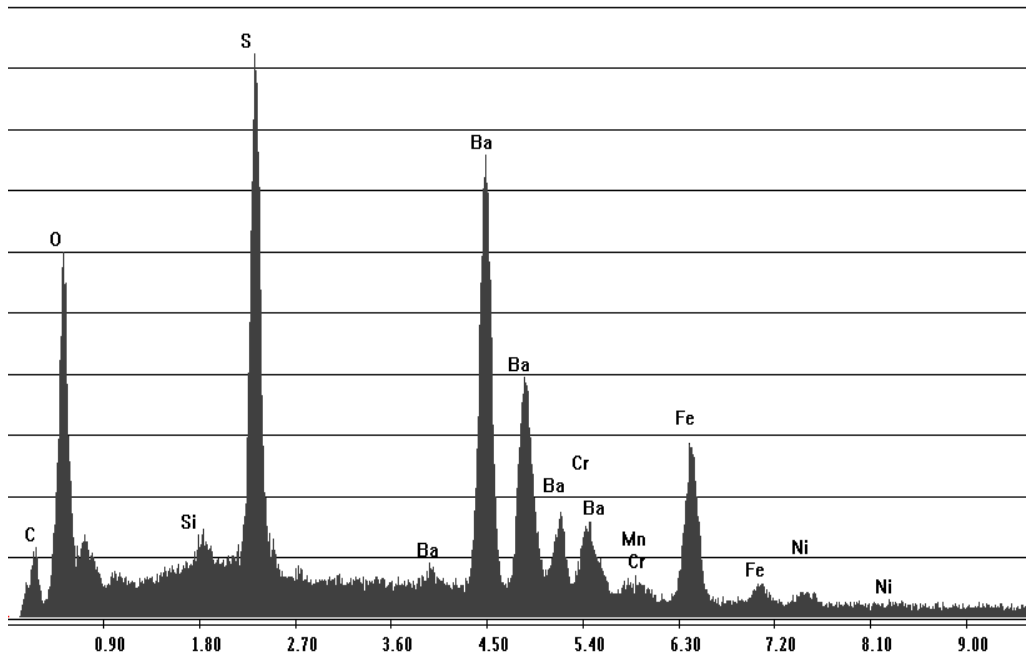

Figura 97 - Espectros da análise por EDS na inclusão (ponto 1 da Figura 96 ): nota-se elevado teor de $\mathrm{S}$ e $\mathrm{Ba}$, além de $\mathrm{Si}$. Cabe ressaltar que os teores de $\mathrm{Cr}$, Fe e Ni correspondem à matriz. 


\section{- $\quad$ ELETRÓliTO DE 0,6M NaBr}

De forma semelhante ao caso anterior $(0,6 \mathrm{M} \mathrm{NaCl})$, a Figura 98 apresenta duas regiões com pites com um residual de inclusão nos seus respectivos interiores. A Figura 99 mostra o resultado da análise por EDS realizada nesses resíduos, que se encontram no interior do pite, através do qual se observa uma inclusão rica em $\mathrm{S}$ e $\mathrm{Ba}$, e em menor porcentagem em Si, indicando que aqui, se repete o fenômeno observado para o aço 304 em 0,6M NaCl.

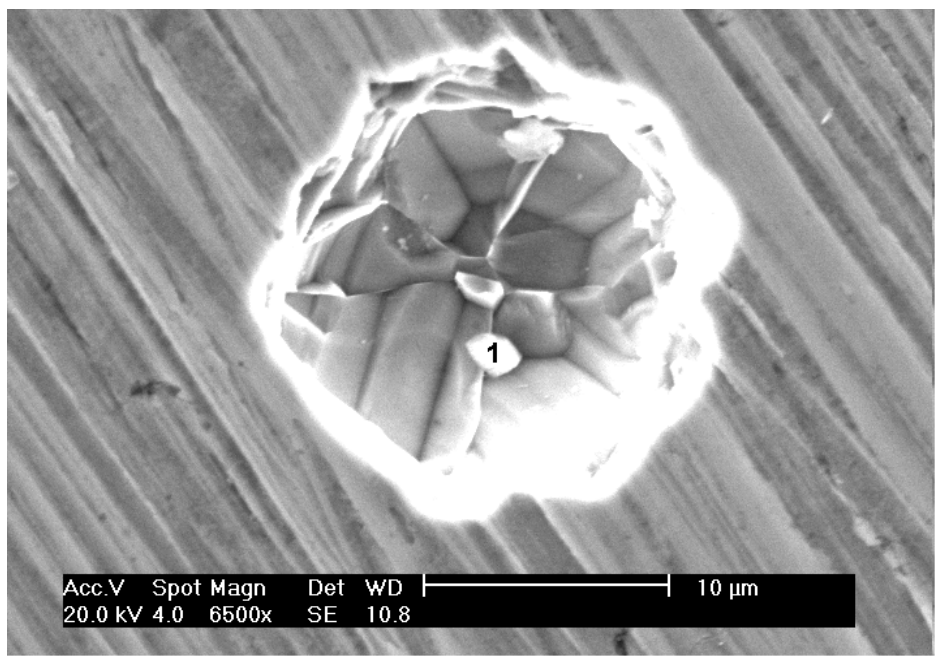

(a)

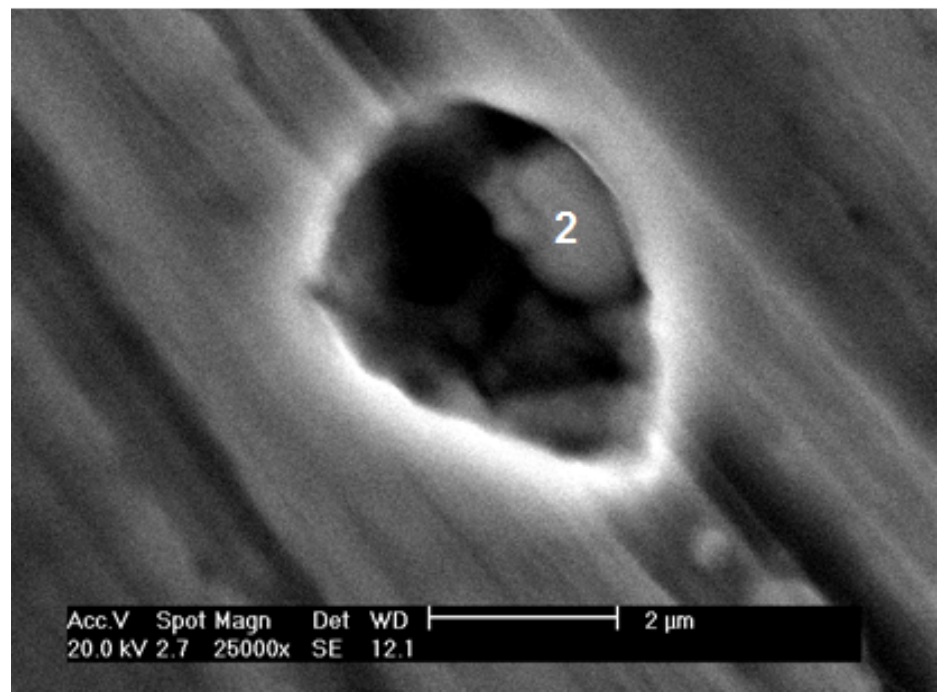

(b)

Figura 98 - Pites contendo um residual de inclusão (ponto 1 e ponto 2). Aço $316 \mathrm{l} \mathrm{em} \mathrm{0,6 \textrm {M }}$ $\mathrm{NaBr}$. Imagem de elétrons secundários e aumento (a) 6500x e (b) 25000x. 


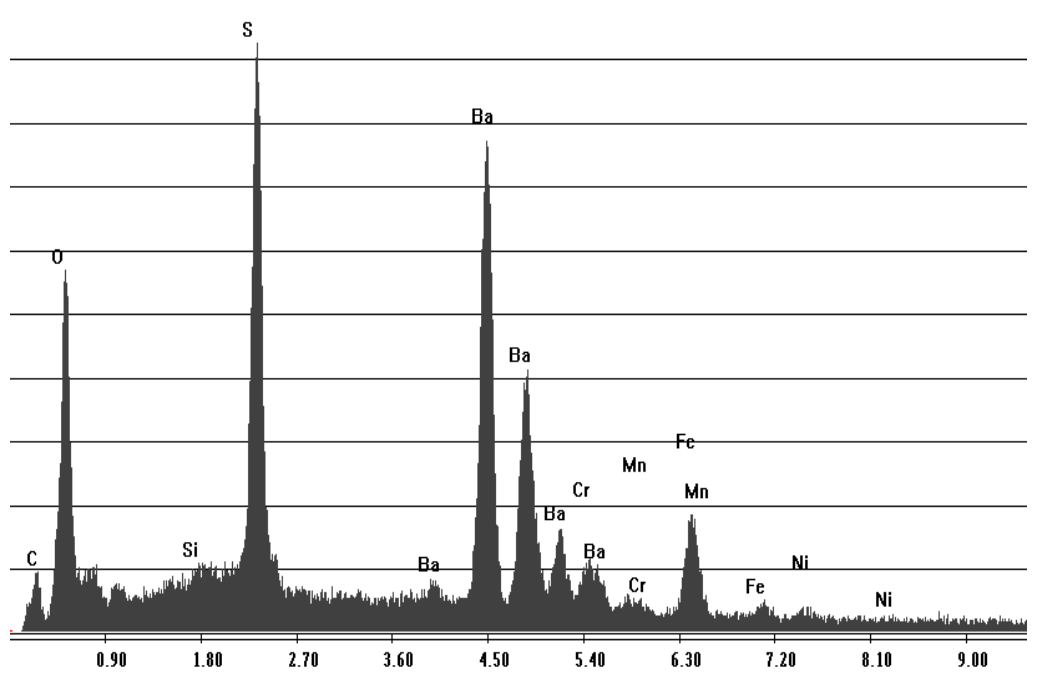

Figura 99 - Espectro da análise por EDS na inclusão do ponto 1 da Figura 98: nota-se elevado teor de $\mathrm{S}$ e $\mathrm{Ba}$ e em menor quantidade $\mathrm{Si}$. Cabe ressaltar que os teores de $\mathrm{Cr}, \mathrm{Fe}$ e $\mathrm{Ni}$ correspondem à matriz. $\mathrm{A}$ análise para o ponto 2 da Figura 98 apresentou o mesmo resultado.

\subsubsection{AÇO INOXIDÁVEL AUSTENÍTICO 430}

\section{- $\quad$ ELETRÓLITO DE 0,6M NaCl}

Novamente, é mostrada a nucleação de um pite em uma inclusão não metálica (Figura 100). O resultado da análise por EDS realizada sobre a inclusão é mostrado na Figura 101, através do qual são observados teores S, $\mathrm{Ba}$ e Si, evidenciando que esta inclusão está composta, em princípio, por um sulfeto de $\mathrm{Ba}$ e um óxido $\mathrm{Si}$. Tais resultados, mostram que a discussão anterior para os aços 304 em $\mathrm{NaCl}$ e 316L em NaCl e $\mathrm{NaBr}$, são válidas também para o aço 430 em NaCl. 


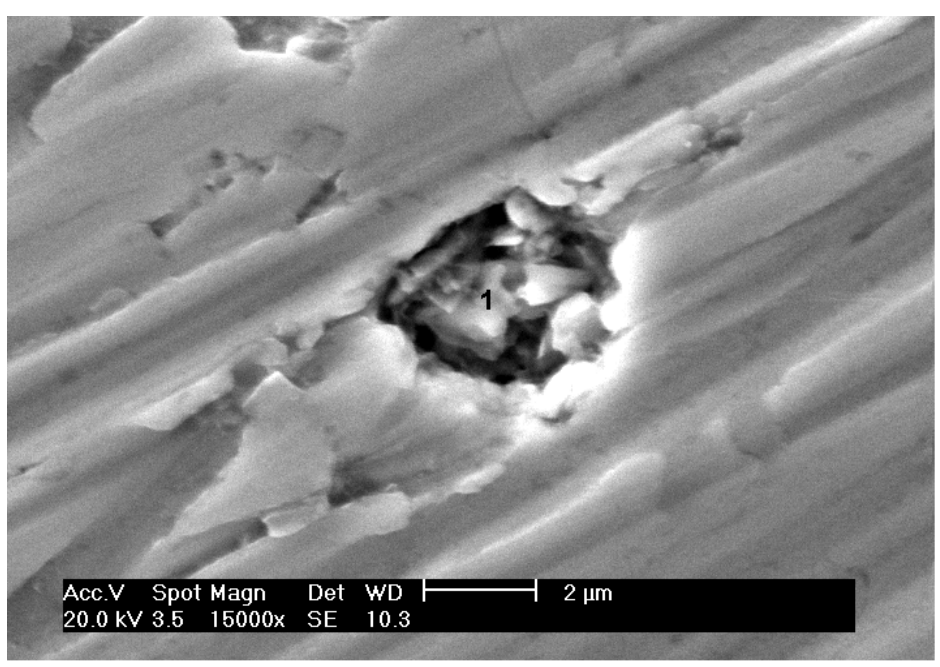

Figura 100 - Pite contendo residual de inclusão (ponto 1). Aço 430 em 0,6M NaCl. Imagem de elétrons secundários e aumento de 15000x

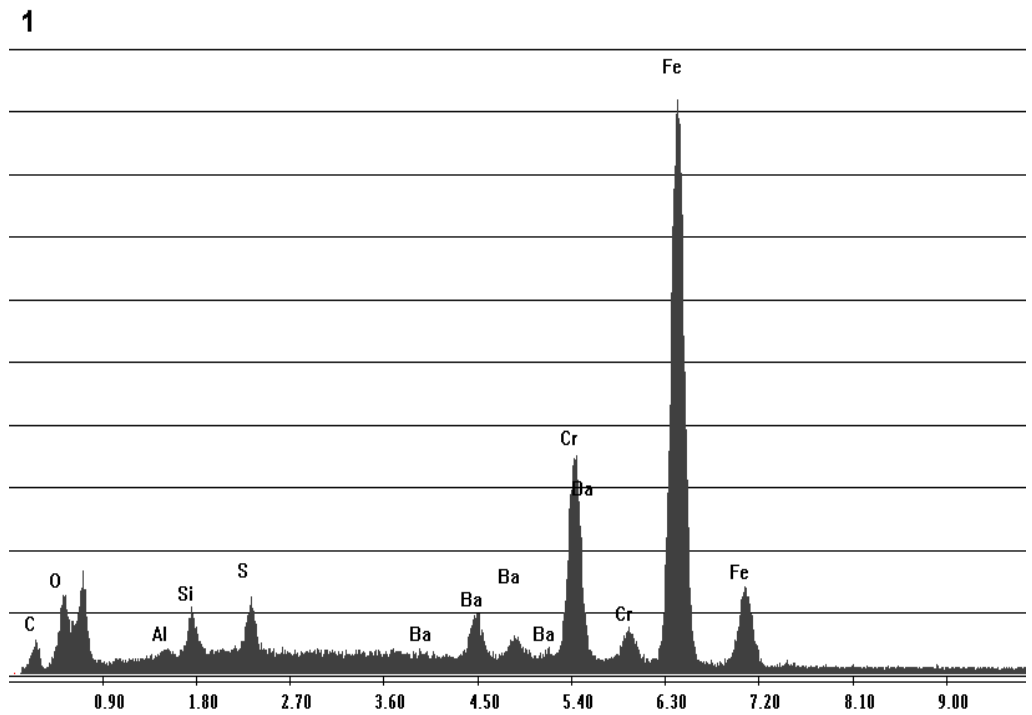

Figura 101 - Espectro da análise por EDS na inclusão (ponto 1 da Figura 100): nota-se elevado teor de $\mathrm{S}, \mathrm{Ba}$ e Si. Já no caso dos teores de $\mathrm{Cr}$, $\mathrm{Fe}$ e Ni, eles correspondem à matriz.

\section{- $\quad$ ELETRÓlito DE 0,6M NaBr}

A Figura 102 mostra a nucleação de pite, em estágio ainda inicial, em uma inclusão não metálica (ponto 1) que não foi dissolvida. A nucleação do pite ocorreu pela dissolução da interface. O resultado da análise por EDS (Figura 103), mostra que se trata de uma inclusão rica em Si e $\mathrm{Mg}$, e em menor 
porcentagem o Al, evidenciando que se trata de um óxido desses elementos. A Figura 102(b) apresenta um pite em estágio avançado de crescimento, o qual, provavelmente, nucleou na interface da inclusão insolúvel. Como nos casos anteriores, aqui vale o mecanismo de Baker e Clastle(65) que explica a nucleação de pites em interfaces matriz/inclusões insolúveis.

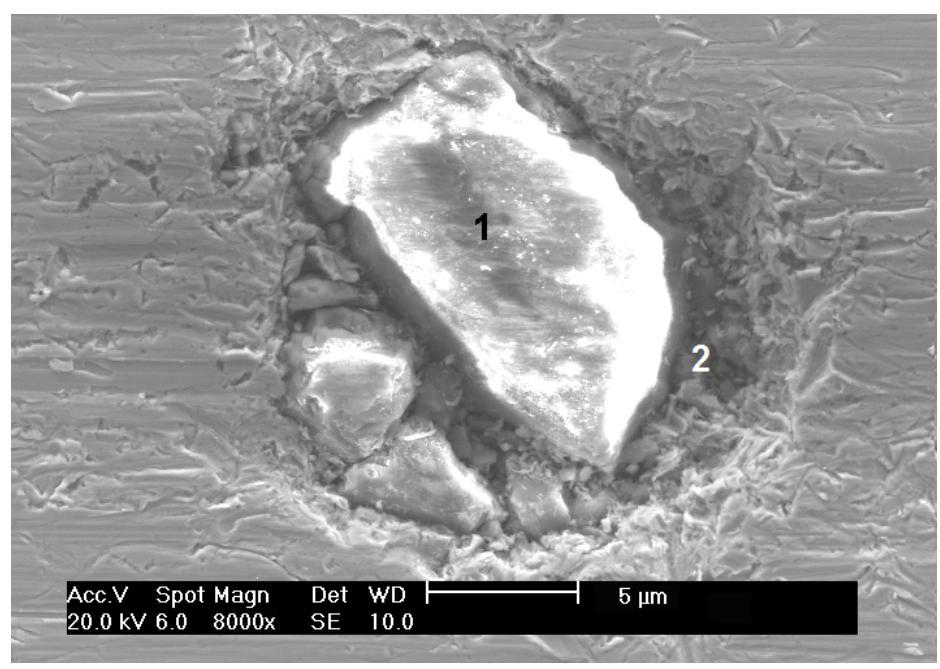

(a)

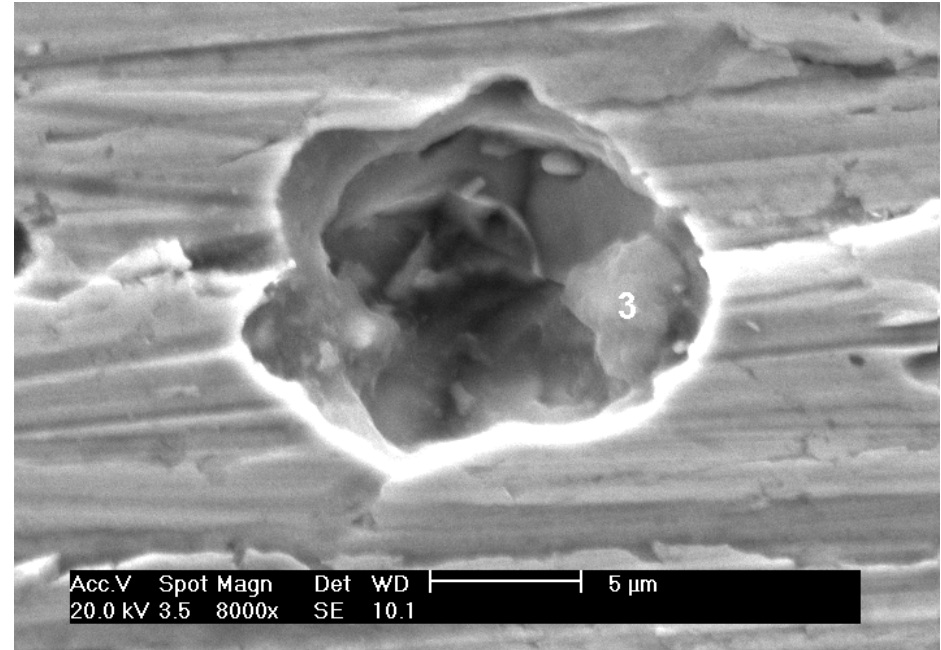

(b)

Figura 102 - Em (a), tem-se a nucleação de pite na interface da inclusão, ainda em estágio inicial, assemelhando-se a uma microfresta (região 2); em (b) tem-se um pite, em estágio avançado de crescimento, provavelmente nucleado na interface da inclusão (ponto 3). Aço 430 em 0,6M NaBr. Imagem de elétrons secundários e aumento de 8000x. 


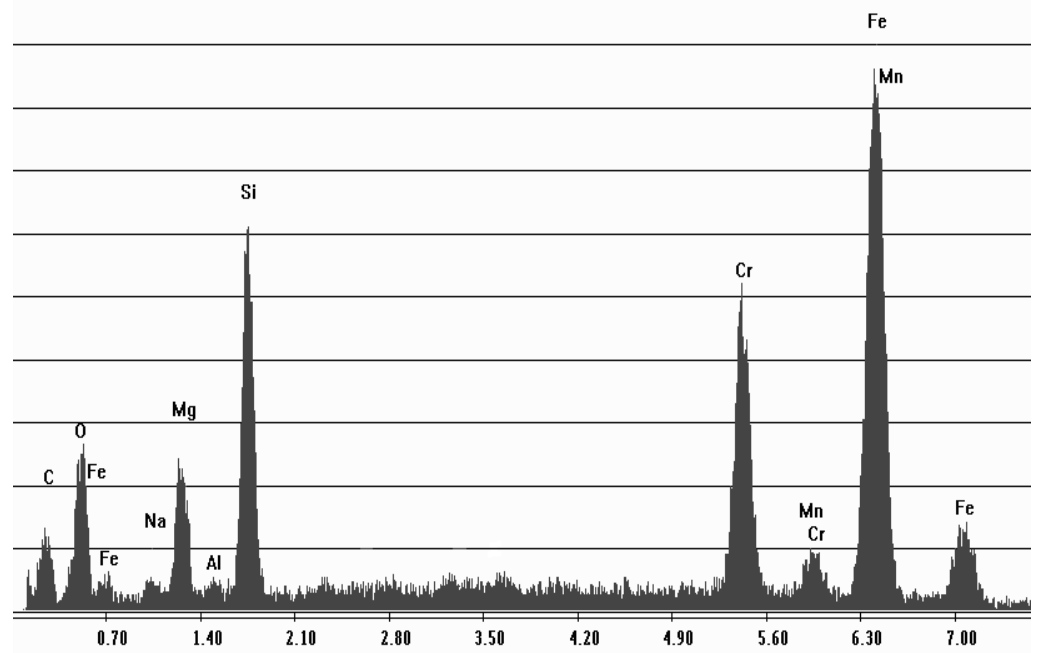

Figura 103 - Espectro da análise por EDS na inclusão (ponto 1 da Figura 102): nota-se elevado teor de $\mathrm{Si}$ e $\mathrm{Mg}$, além Al. Já no caso dos teores de $\mathrm{Cr}$, $\mathrm{Fe}$ e $\mathrm{Ni}$, eles correspondem à matriz. $\mathrm{A}$ análise para a inclusão do ponto 3 da Figura 102 (b) apresentou o mesmo resultado.

\subsubsection{AÇO INOXIDÁVEL AUSTENÍTICO 444}

\section{- $\quad$ ELETRÓLITO DE 0,6M NaCl}

Como nos casos anteriores, a nucleação de um pite ocorre em uma interface matriz/inclusão insolúvel (Figura 104). A Figura 105 mostra o resultado da análise por EDS realizada na inclusão, indicando elevado teor de $\mathrm{Al}$, e em menor porcentagem Si. A partir dessa composição, verifica-se que se trata de uma inclusão de óxido de $\mathrm{Al}$ e $\mathrm{Si}$, a qual é insolúvel. Desse modo, pode-se afirmar que a parte dissolvida foi basicamente, metal da matriz do aço.

Além disso, tem-se também a evidência da Figura 106. Nesta figura, o ensaio de polarização foi realizado, excepcionalmente, para uma superfície polida até $3 \mu \mathrm{m}$. Esse exame mostra que o pite nucleou na interface matriz/inclusão de óxido de Al e Si.

Igualmente aos casos anteriores, estes resultados indicam a validade do mecanismo de Baker e Castle(65). 


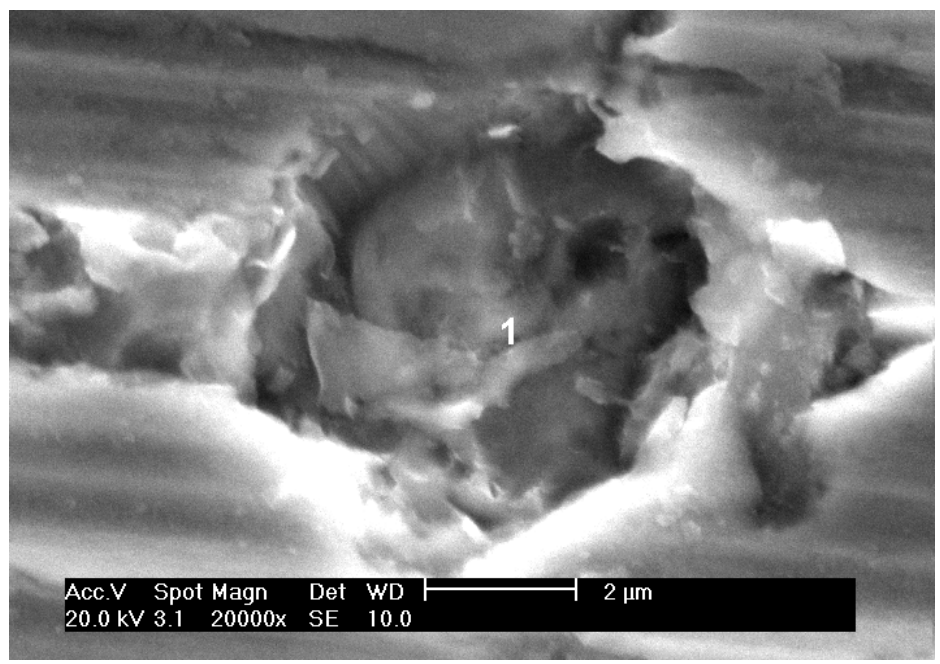

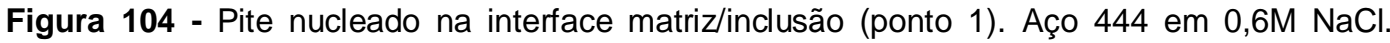
Imagem de elétrons secundários e aumento de 20000x.

1

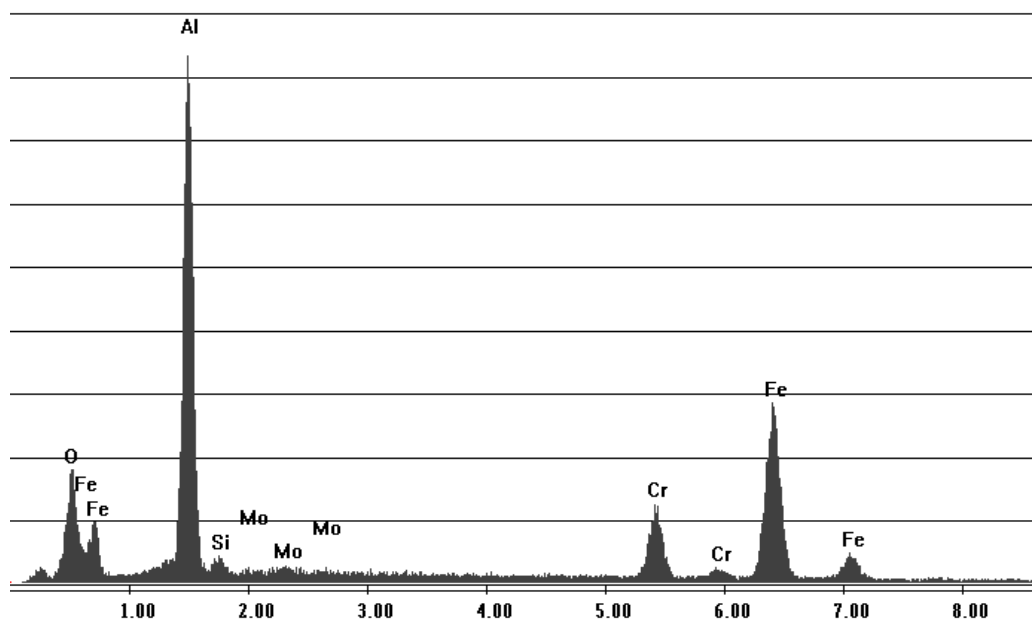

Figura 105 - Espectro da análise por EDS na inclusão (ponto 1 da Figura 104): nota-se elevado teor de $\mathrm{Al}$ e em menor teor, Si. Já no caso dos teores de $\mathrm{Cr}$, $\mathrm{Fe}$ e Ni, eles correspondem à matriz. 


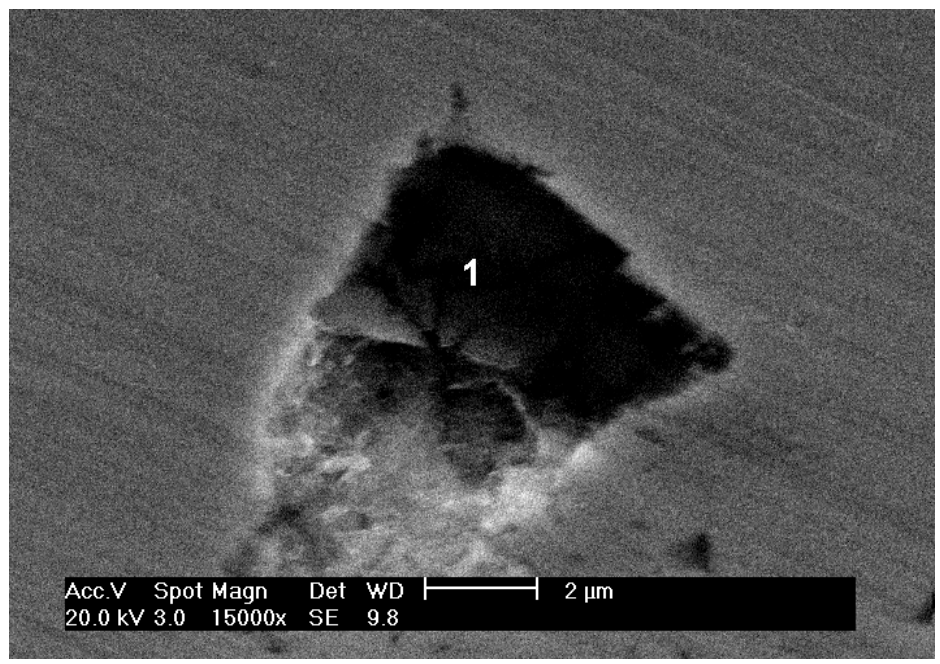

Figura 106 - Pite nucleado na interface matriz/inclusão (ponto 1). Aço 444 em 0,6M NaCl. Imagem de elétrons secundários e aumento de 15000x. Superfície polida até $3 \mu \mathrm{m}$.

1

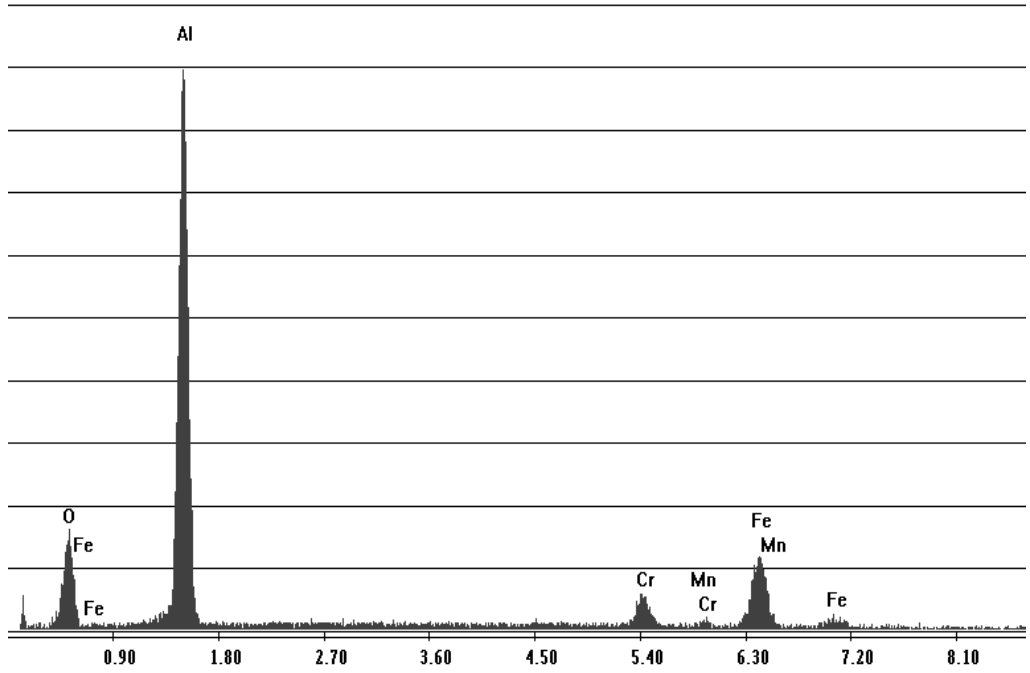

Figura 107 - Espectro da análise por EDS na inclusão (ponto 1 da Figura 106): nota-se elevado teor de $\mathrm{Al}$ e em menor teor, Si. Já no caso dos teores de $\mathrm{Cr}$, $\mathrm{Fe}$ e Ni, eles correspondem à matriz.

- $\quad$ ELETRÓLITO DE 0,6M NaBr

Novamente este material apresenta a nucleação de pites (Figura 108) em inclusões que não são dissolvidas durante o processo de corrosão. O resultado da análise por EDS (Figura 109) mostra que se tratam de inclusões ricas em Si, evidenciando óxido de Si. 


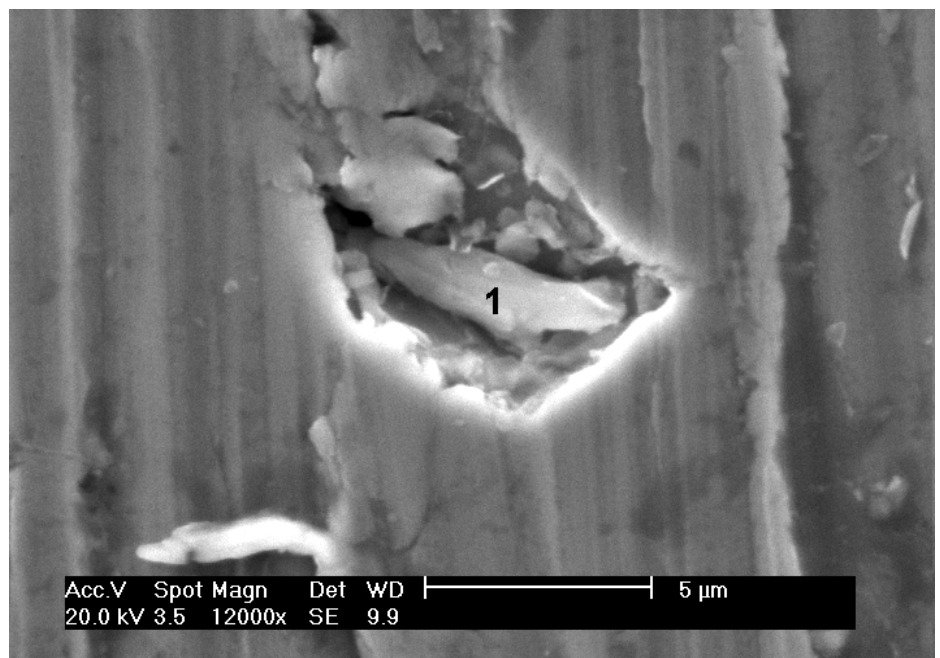

(a)

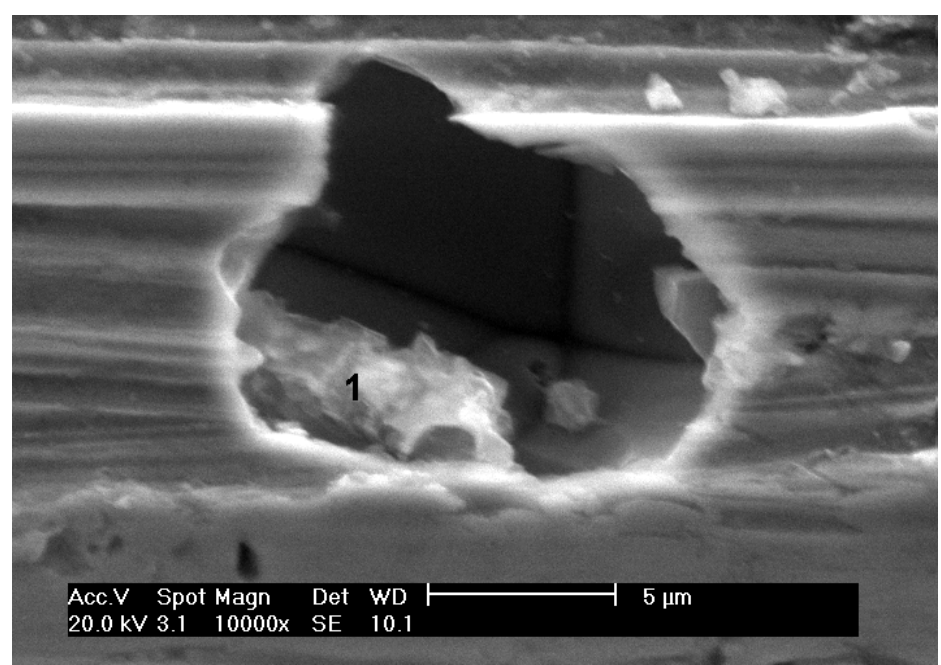

(b)

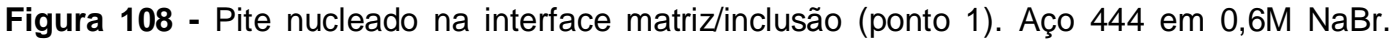
Imagem de elétrons secundários. Superfície polida até $3 \mu \mathrm{m}$. (a) aumento de 12000x e para (b) 10000x. 


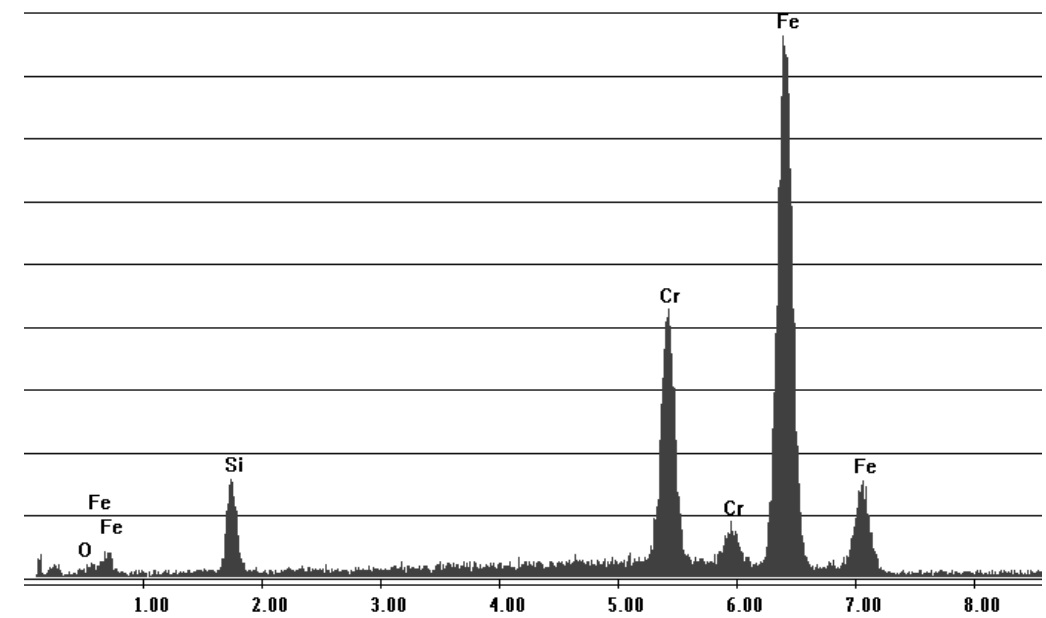

Figura 109 - Espectro da análise por EDS na inclusão (ponto 1 da Figura 109 (a)): nota-se a presença de $\mathrm{Si}$. Já no caso dos teores de $\mathrm{Cr}, \mathrm{Fe}$ e Ni, eles correspondem à matriz. (a) e (b) tem o mesmo resultado, ou seja, é uma inclusão de silício nos dois casos.

\section{COMENTÁRIOS GERAIS SOBRE OS SÍTIOS DE NUCLEAÇÃO DE PITE}

$\mathrm{Na}$ Tabela 8 é apresentada de forma resumida a relação entre o tipo de inclusão e a susceptibilidade à nucleação de pite para cada aço.

Tabela 8 - Resumo das inclusões que mostraram maior susceptibilidade à corrosão por pite.

\begin{tabular}{|c|c|c|c|}
\hline $\begin{array}{c}\text { AÇO } \\
\text { INOXIDÁVEL }\end{array}$ & $\begin{array}{c}\text { INCLUSÕES ANTES DA } \\
\text { CORROSÃO }\end{array}$ & $\begin{array}{c}\text { INCLUSŌES } \\
\text { SUSCEPTÍVEIS À } \\
\text { PITE }\end{array}$ & ÍON AGRESSIVO \\
\hline \multirow{2}{*}{298} & \multirow{2}{*}{$\begin{array}{c}\text { Óxidos de Al e Si } \\
\text { MnS }\end{array}$} & Óxido de $\mathrm{Si}$ & $\mathrm{NaCl}$ \\
\hline & & Óxido de Si e Al & $\mathrm{NaBr}$ \\
\hline \multirow[b]{2}{*}{304} & \multirow{2}{*}{$\begin{array}{c}\text { Óxido de } \mathbf{C a}, \mathrm{Si}, \mathbf{M g} \\
\text { e Al } \\
\text { Óxido de } \mathbf{M g}, \mathrm{Al}, \mathbf{M n} \\
\text { MnS } \\
\text { Óxido de Al }\end{array}$} & BaS & $\mathrm{NaCl}$ \\
\hline & & Óxido de Al & $\mathrm{NaBr}$ \\
\hline \multirow{2}{*}{$316 \mathrm{~L}$} & \multirow{2}{*}{$\begin{array}{c}\text { Óxido de Si } \\
\text { Óxido de Al e Si } \\
\text { MnS }\end{array}$} & $\mathrm{BaS}$ & $\mathrm{NaCl}$ \\
\hline & & $\mathrm{BaS}$ & $\mathrm{NaBr}$ \\
\hline \multirow[b]{2}{*}{430} & \multirow{2}{*}{$\begin{array}{c}\text { Óxido de Al } \\
\text { Óxido de Al e Si } \\
\text { Óxido de Al, Si e Ba }\end{array}$} & $\mathrm{BaS}$ & $\mathrm{NaCl}$ \\
\hline & & $\begin{array}{c}\text { Óxido de } \mathrm{Si}, \mathrm{Mg} \\
\text { e Al }\end{array}$ & $\mathrm{NaBr}$ \\
\hline \multirow{2}{*}{444} & \multirow{2}{*}{$\begin{array}{c}\text { Oxido de Si } \\
\text { (Nb,Ti)(C,N) } \\
\text { Oxido de } \mathrm{Al}+\mathrm{MgS} \\
\end{array}$} & Óxido de Al & $\mathrm{NaCl}$ \\
\hline & & Óxido de $\mathrm{Si}$ & $\mathrm{NaBr}$ \\
\hline
\end{tabular}


Independentemente do aço, os pites destacaram-se por nuclearem geralmente em inclusões não metálicas com tamanhos de aproximadamente $4 \mu \mathrm{m}$.

Examinando a Tabela 8 nota-se a presença de inclusões de óxidos de Al e Si e MnS no aço 298. Após ensaio para a nucleação de pites, as análises revelaram que os pites estão associados às inclusões de óxidos de Al e Si. Não foram encontrados pites associados às inclusões de MnS, no entanto, também não foram encontradas as inclusões de MnS originais do material. Isso pode ser uma evidência de que as inclusões de MnS foram dissolvidas, mas não tiveram a capacidade de nuclear o pite; talvez, isso seja consequência do tamanho destas inclusões (arredondadas e menores do que $1 \mu \mathrm{m}$ e alongadas com cerca de $2 \mu \mathrm{m}$ - Figura 30 e Figura 48). De fato, a Figura 110 mostra uma curva de polarização onde se tem aumento da densidade de corrente ainda no trecho passivo (região indicada pela seta). Esse aumento da densidade de corrente é citado na literatura(46) como sendo devida à dissolução de MnS. Por sua vez, não sendo possível a nucleação de pite na inclusão de MnS, a nucleação de pites ocorreu em potencial mais alto, sendo os sítios de nucleação atuantes as inclusões de óxidos de Si e Al, cujo mecanismo já foi mencionado anteriormente. 


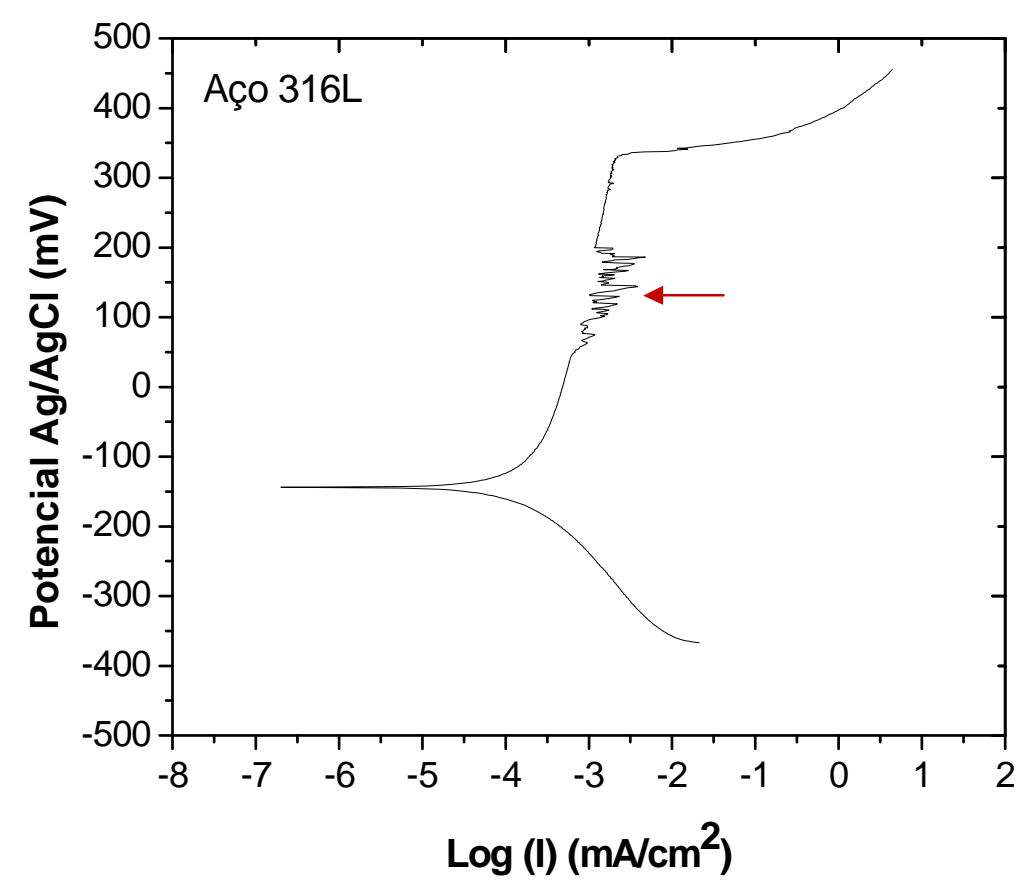

Figura 110 - Curva de polarização potenciodinâmica do aço $316 \mathrm{~L}$ no eletrólito $0,3 \mathrm{M}$ $\mathrm{NaCl}+0,3 \mathrm{M} \mathrm{NaBr}$. Nota-se um aumento drástica da densidade de corrente em potenciais próximos de $150 \mathrm{mV}$.

No caso do aço 304, situação semelhante é observada. No entanto, a composição química das inclusões de óxidos e sulfetos é um pouco mais variada. $\mathrm{O}$ aço 304 tem inclusões de óxidos de $\mathrm{Si}, \mathrm{Al}$, mas, na mesma análise encontram-se $\mathrm{Ca}, \mathrm{Mg}$ e $\mathrm{Mn}$. Como as análises por EDS não indicaram a presença de $\mathrm{S}$, inicialmente, imagina-se que os elementos $\mathrm{Ca}, \mathrm{Mg}$ e $\mathrm{Mn}$ estejam combinados na forma de óxidos. No entanto, sabe-se que a adição de $\mathrm{Ca}$ e Mg tem como objetivo a dessulfuração dos aços, e que a presença de $\mathrm{Mn}$ nos aços, sempre está ligada à inclusões de MnS. Desse modo, não se pode descartar que as inclusões do aço 304 sejam um misto de óxidos e sulfetos. Corrobora essa idéia, o resultado da análise das inclusões após corrosão por pite (Tabela 8), onde foram encontrados pites associados à inclusões de BaS, além de óxidos de Al. Por sua vez, não foram encontradas inclusões de BaS antes do ensaio de corrosão por pite. Talvez, o que explica isso, seja o fato de primeiro se ter a exposição de MnS, que após dissolvidos, permitiram a exposição de $\mathrm{BaS}$, com consequente dissolução. ( $\mathrm{Ca}$ e $\mathrm{Mg}$ são adicionados para a dessulfuração do aço; o elemento Ba pertence a mesma família de 
elementos químicos. Embora não tenham sido encontradas referências sobre a adição proposital de Ba para a dessulfuração, presume-se que as ligas de Ca e $\mathrm{Mg}$ adicionadas estejam contaminadas com $\mathrm{Ba}$.)

O aço 316L corrobora a discussão acima (aço 304), pois o aço $316 \mathrm{~L}$ apresentou na caracterização inclusões de óxidos de $\mathrm{Al}$ e $\mathrm{Si}$, e de MnS. E, após a corrosão, foram encontrados pites associados a inclusões de BaS. Em resumo, explica-se isso através da dissolução de MnS, eventualmente sem a nucleação de pites, seguida da dissolução de BaS, com nucleação e crescimento de pites.

Igualmente, o aço 430, apresentou os mesmos mecanismos de nucleação de pites em inclusões do que o aço 304.

Ainda convém levantar outra hipótese para os precipitados contendo $\mathrm{Ba}$ que foram encontrados no interior dos pites. Primeiramente, está se supondo que o elemento $\mathrm{Ba}$ tenha sido adicionado juntamente com $\mathrm{Ca}$ e $\mathrm{Mg}$ no processo de elaboração do aço, gerando então, inclusões de sulfeto de Ba e outros elementos. Por outro lado, foram utilizados eletrólitos de $\mathrm{NaBr}$ e $\mathrm{NaCl}$, sempre PA (puros para análise). Apesar dessa condição PA, consultando a especificação dos fabricantes dos sais utilizados, encontram-se $0,002 \% \mathrm{Ba}$ no $\mathrm{NaBr}$ e $0,001 \%$ Ba no $\mathrm{NaCl}$, além de $0,002 \% \mathrm{SO}_{4}{ }^{-2}$ no $\mathrm{NaBr}$ e $0,004 \% \mathrm{SO}_{4}^{-2}$ no $\mathrm{NaCl}$. Lembrando que todos esses elementos estarão no interior da cavidade do pite nucleado, pode-se pensar também numa possível precipitação de um sal de $\mathrm{Ba}$ (cloreto e/ou sulfato de bário).

Por fim, o aço 444 caracterizou-se por apresentar pites associados a inclusões de óxidos de Al e Si. Este aço apresentou sinais de inclusões contendo Mg, que pode estar na forma de MgS (Figura 66). Essas inclusões eram relativamente pequenas (cerca de $1 \mu \mathrm{m}$ ). Novamente, pode-se pensar na sua dissolução e, considerando-se seu pequeno volume, é provável que não ocorra a nucleação de pite.

Vale ressaltar, que o aço 444 apresentou também precipitados de carbonitretos de nióbio e titânio, mas estes não interferiram na nucleação de pites.

Uma última hipótese é que as inclusões de óxidos tenham ao seu redor, compostos de S. Com a dissolução da parte composta por sulfeto, fica aberta a interface matriz/inclusão de óxido, sendo aí um sitio de nucleação de pite. 


\subsubsection{MORFOLOGIA DOS PITES}

A morfologia dos pites formados nos ensaios de polarização potenciodinâmica foi examinada através de MEV. Além disso, sempre que possível, foram feitas análises químicas elementares por EDS para identificar detalhes dos produtos de corrosão originados no interior dos pites.

\subsubsection{AÇO INOXIDÁVEL AUSTENÍTICO 298}

A Figura 111 mostra a distribuição dos pites nucleados na superfície do aço 298 durante o ensaio de polarização potenciodinâmica. Da Figura 111 pode-se concluir que no eletrólito de $0,45 \mathrm{M} \mathrm{NaCl}+0,15 \mathrm{M} \mathrm{NaBr}$ apresentou a maior densidade de pites.

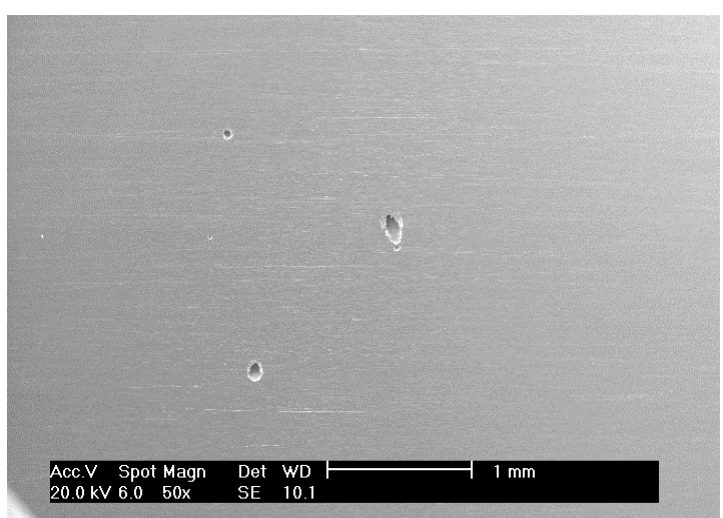

(a)

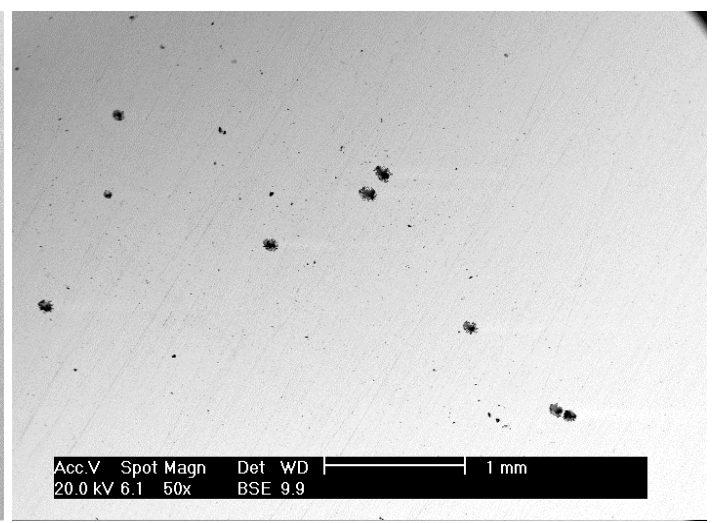

(b) 


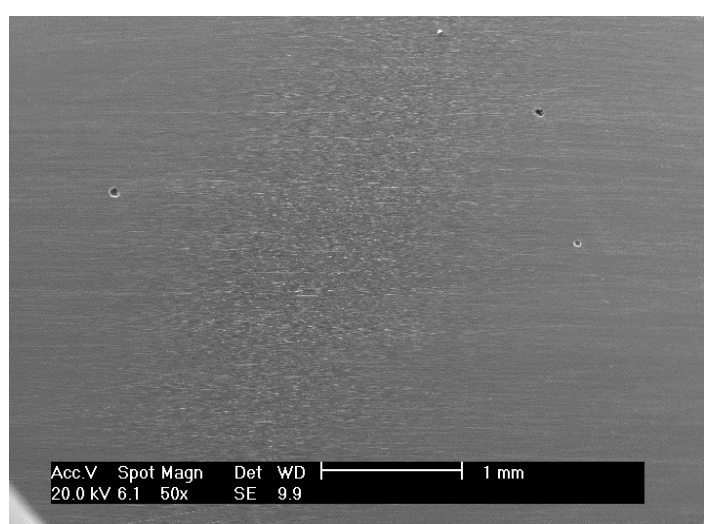

(c)

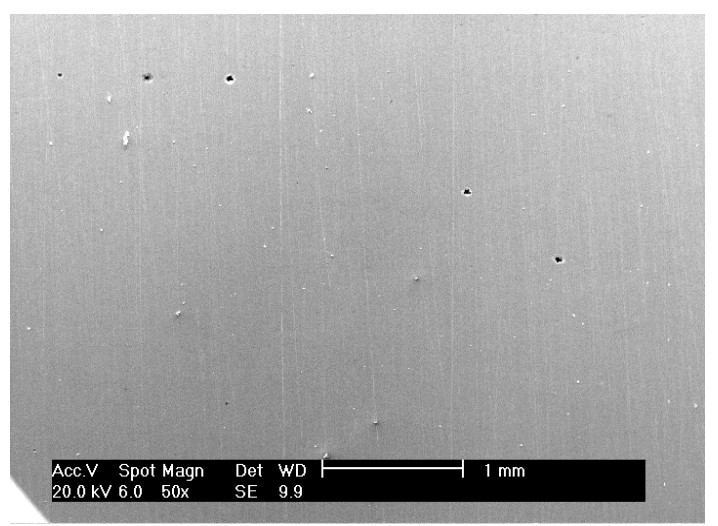

(d)

Figura 111 - Imagem de elétrons secundários para o aço 298. Distribuição dos pites na superfície do aço 298.(a) $0,6 \mathrm{M} \mathrm{NaCl}$, (b) $0,45 \mathrm{M} \mathrm{NaCl}+0,15 \mathrm{M} \mathrm{NaBr}$, (c) $0,3 \mathrm{M} \mathrm{NaCl}+0,3 \mathrm{M} \mathrm{NaBr}$ e (d) 0,6M NaBr. Lixa \#600. Aumento 50x.

O aspecto dos pites nucleados na superfície do aço 298 durante o ensaio polarização potenciodinâmica é apresentado na Figura 112. Pode-se observar através da Figura 112, que os pites têm formato hemisférico (dissolução isotrópica) e estão livres de resíduos de corrosão nos seus interiores. Cabe salientar, que as Figura 112(a),(b) e (c) apresentam pites abertos na parte superior (livre da camada de metal remanescente), já na Figura 112(d), é apresentado um pite com esta camada remanescente, a qual está sendo corroída localizadamente. Existe uma concordância geral que a camada de metal que recobre o pite é um importante fator estabilizante para seu crescimento(68),(69). Consequentemente, esta camada atua como uma barreira física(70), evitando a troca entre o eletrólito e o fluido que se encontra no interior do pite, ajudando manter um ambiente agressivo e conservando as condições favoráveis para o crescimento estável do pite.

O fato desses pites não apresentarem indícios de terem sido nucleados em inclusões não metálicas, isso não significa que não tenha ocorrido. $\mathrm{Na}$ medida em que o pite aumenta de tamanho, tem-se a dissolução de certas inclusões e o desprendimento das inclusões não solúveis, de modo que não é possível se determinar o sítio de nucleação de pites através destes exames; é possível, apenas, examinar a morfologia de crescimento dos pites. 


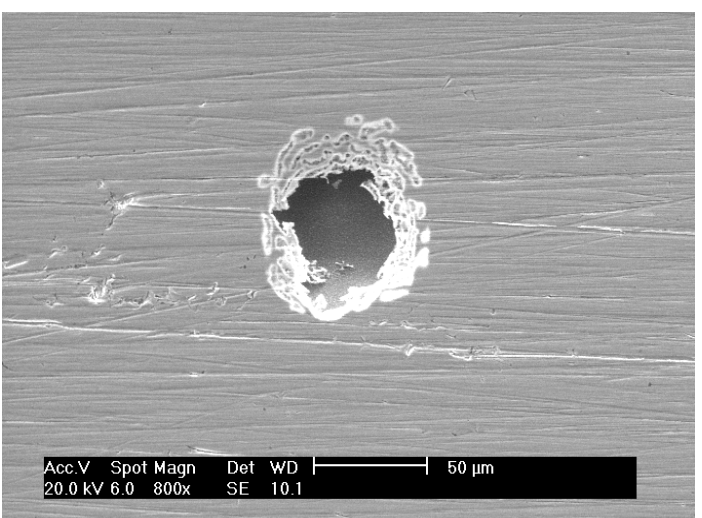

(a)

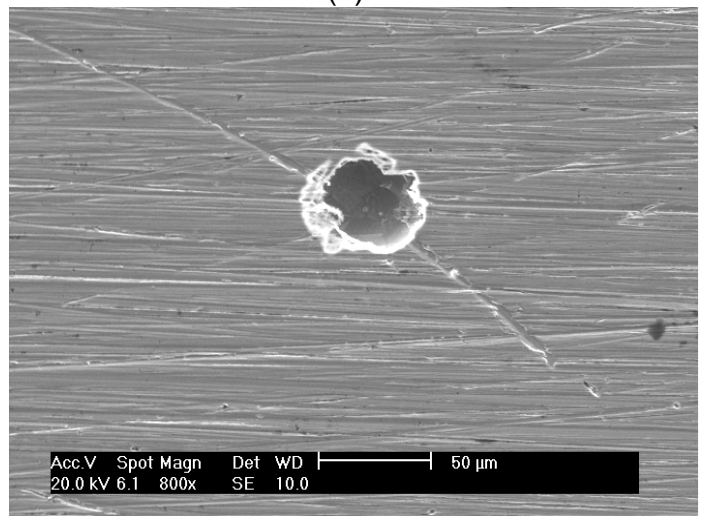

(c)

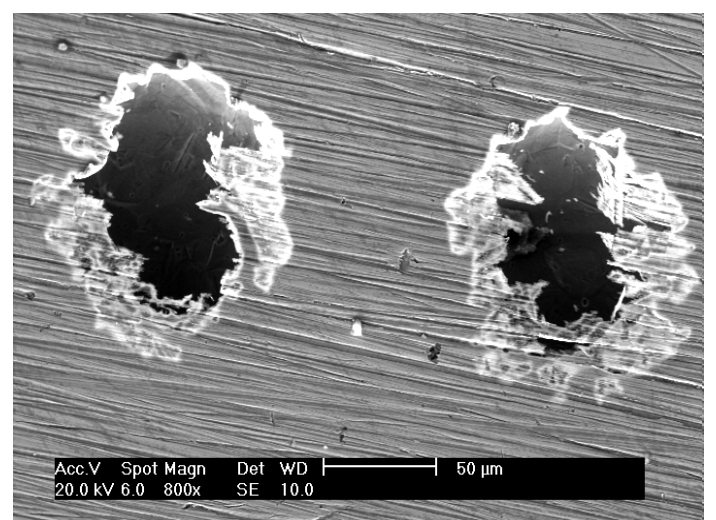

(b)

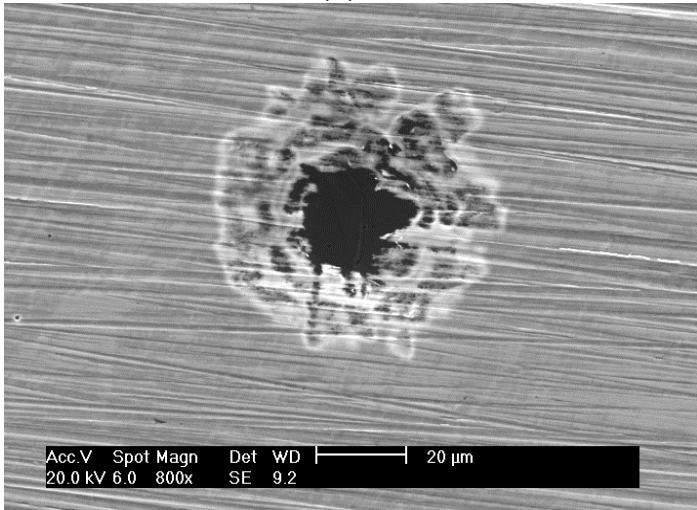

(d)

Figura 112 - Imagens de elétrons secundários dos pites nucleados na superfície do aço 298 durante o ensaio de corrosão. (a) $0,6 \mathrm{M} \mathrm{NaCl}$, (b) $0,45 \mathrm{M} \mathrm{NaCl}+0,15 \mathrm{M} \mathrm{NaBr}$, (c) $0,3 \mathrm{M}$ $\mathrm{NaCl}+0,3 \mathrm{M} \mathrm{NaBr}$ e (d) 0,6M NaBr. Lixa \#600. Aumento 800x.

\subsubsection{AÇO INOXIDÁVEL AUSTENÍTICO 304}

A Figura 113 mostra a distribuição dos pites nucleados na superfície do aço 304 durante o ensaio de polarização potenciodinâmica. Os eletrólitos puros de $0,6 \mathrm{M} \mathrm{NaCl}$ e $0,6 \mathrm{M} \mathrm{NaBr}$ foram os que apresentaram a maior densidade de pites nucleados na superfície do aço. 


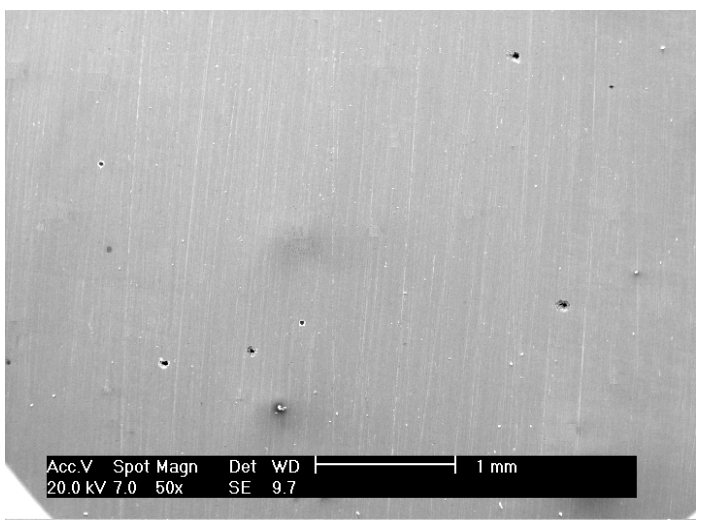

(a)

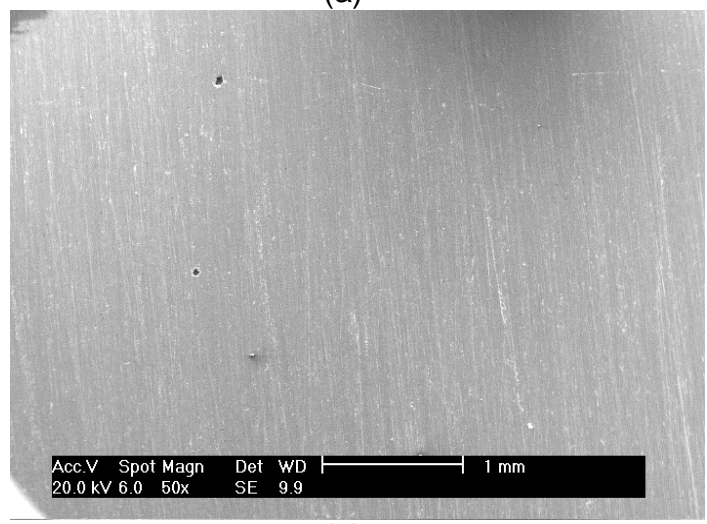

(c)

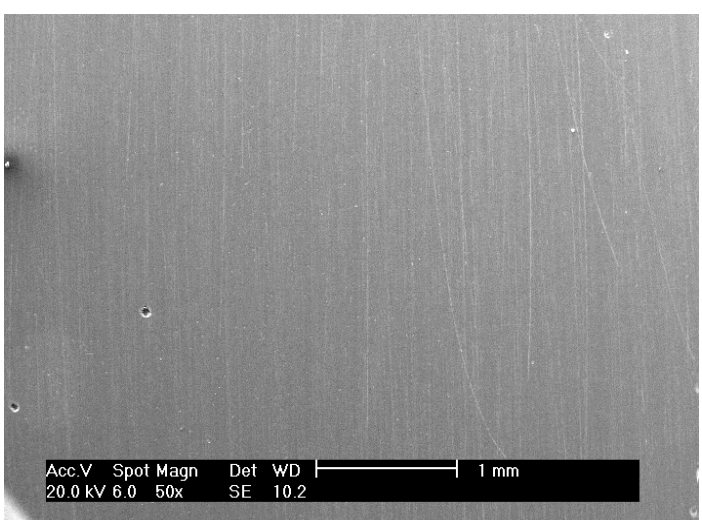

(b)

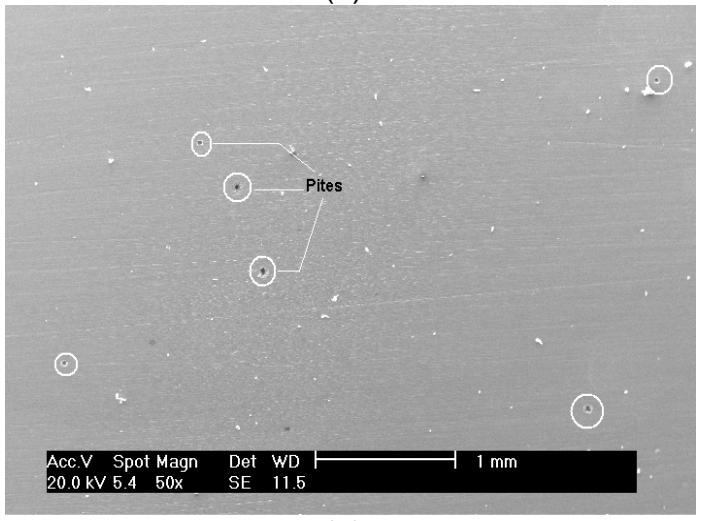

(d)

Figura 113 - Imagem de elétrons secundários para o aço 304. Distribuição dos pites na superfície. (a) $0,6 \mathrm{M} \mathrm{NaCl}$, (b) $0,45 \mathrm{M} \mathrm{NaCl}+0,15 \mathrm{M} \mathrm{NaBr}$, (c) $0,3 \mathrm{M} \mathrm{NaCl}+0,3 \mathrm{M} \mathrm{NaBr}$ e (d) $0,6 \mathrm{M}$ $\mathrm{NaBr}$. Lixa \#600. Aumento 50x.

Igualmente ao aço 298, o aspecto dos pites nucleados na superfície do aço 304 durante o ensaio de corrosão são apresentados na Figura 114. Podese observar que os pites tem formato hemisférico (dissolução isotrópica) e são livres de resíduos de corrosão no seu interior. Cabe salientar, que a Figura 114(a) apresenta um pite aberto na parte superior (livre da camada de metal remanescente), já nas Figura 114(b),(c) e (d), são apresentados pites com esta camada remanescente de metal, a qual está sendo corroída localizadamente. Como no caso anterior, o pite que contém a camada de metal na parte superior, pode manter as condições necessárias no interior do pite para que a repassivação do pite não seja mais possível. 


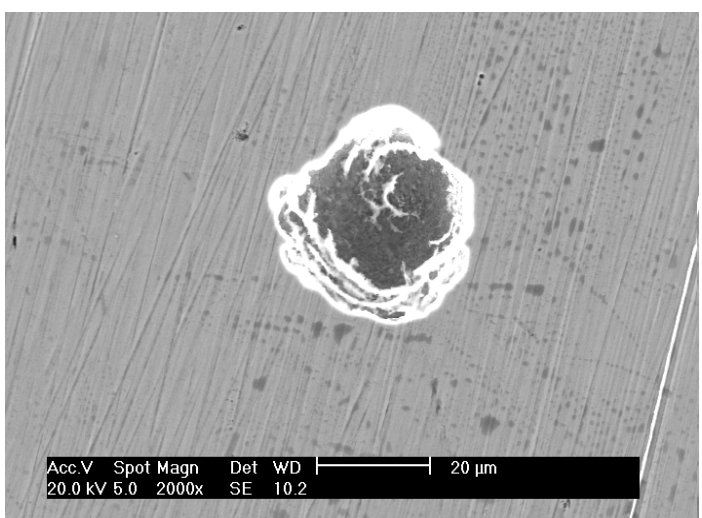

(a)

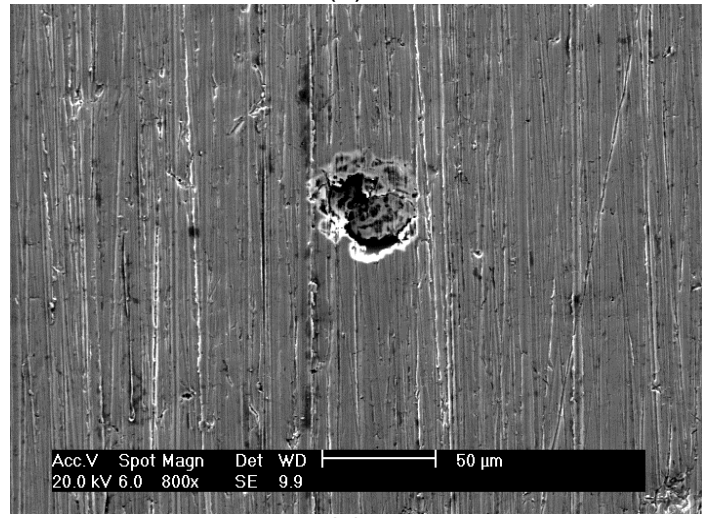

(c)

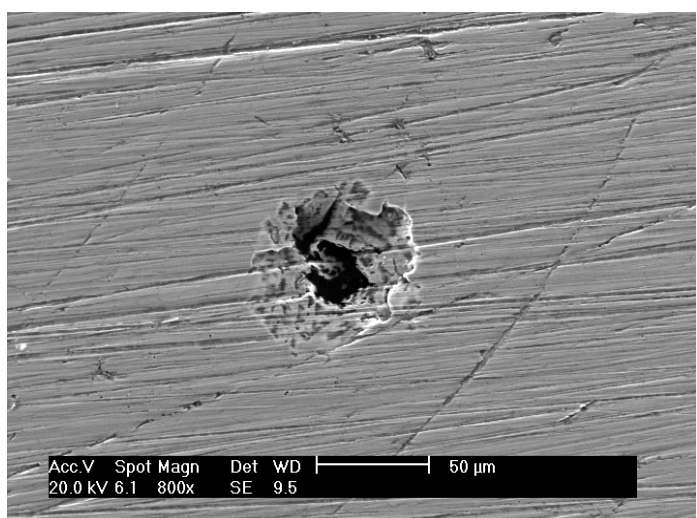

(b)

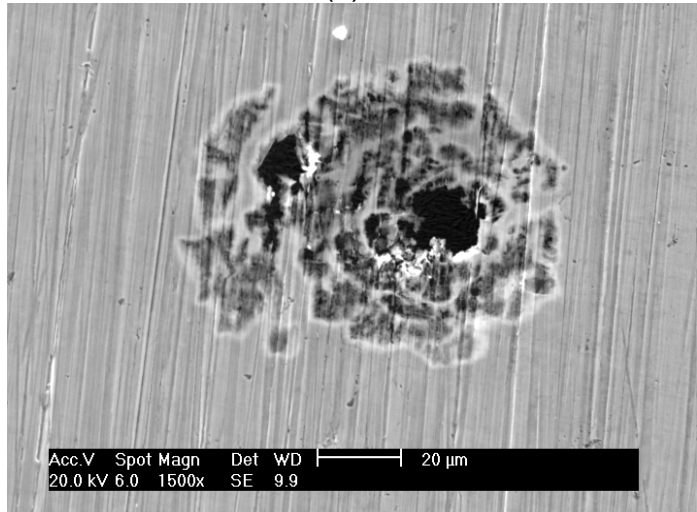

(d)

Figura 114 - Imagens de elétrons secundários dos pites nucleados na superfície do aço 304 durante o ensaio de corrosão. .(a) $0,6 \mathrm{M} \mathrm{NaCl}$, (b) $0,45 \mathrm{M} \mathrm{NaCl}+0,15 \mathrm{M} \mathrm{NaBr}$, (c) $0,3 \mathrm{M}$ $\mathrm{NaCl}+0,3 \mathrm{M} \mathrm{NaBr}$ e (d) 0,6M NaBr. Lixa \#600. Aumento 800x para (a), (b) e (c), e 1500x para (d).

\subsubsection{AÇO INOXIDÁVEL AUSTENíTICO 316L}

Como nos casos anteriores, a Figura 115 mostra a distribuição dos pites nucleados sobre a superfície do aço. Cabe ressaltar, que a Figura 115 mostra uma baixa densidade de pites em quase todos os eletrólitos testados, quando comparado com os aços anteriores (298 e 304). De fato, este comportamento poderia estar relacionado o com efeito benéfico do molibdênio em ambientes agressivos que contém cloreto. 


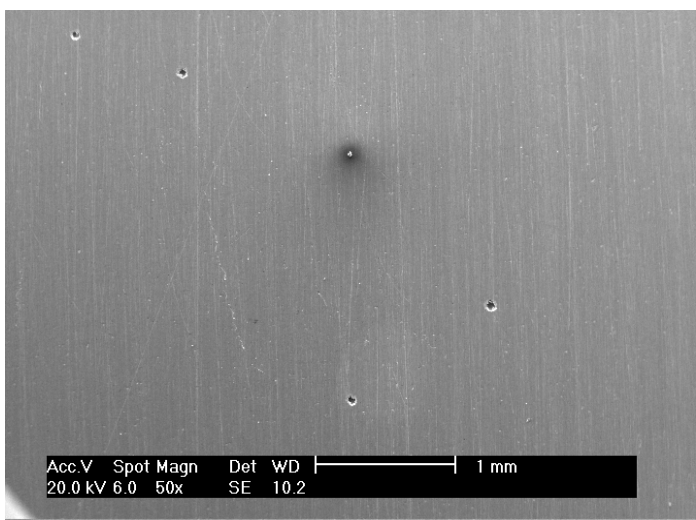

(a)

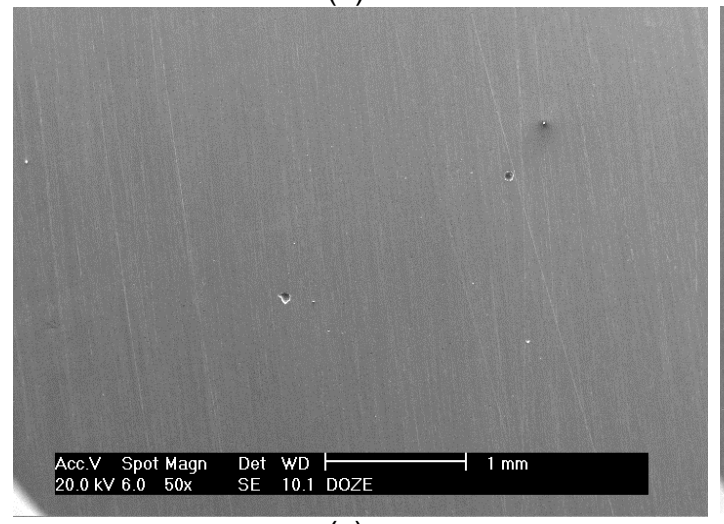

(c)

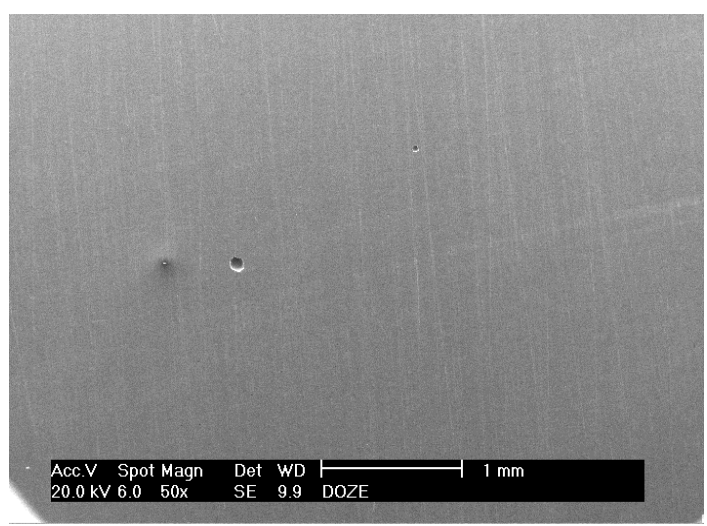

(b)

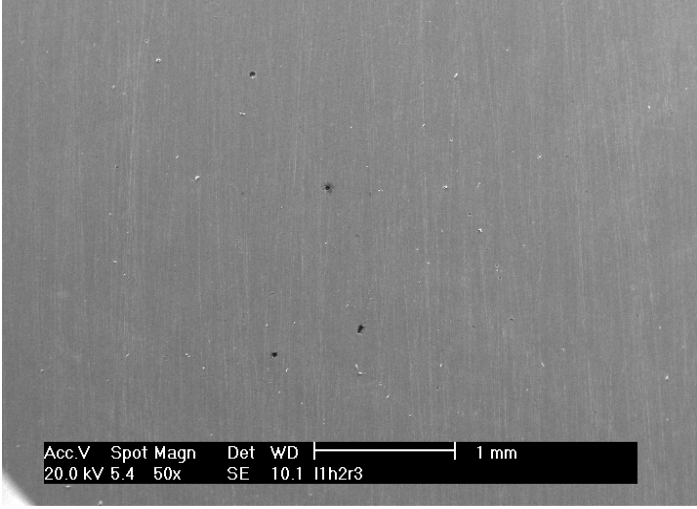

(d)

Figura 115 - Imagem de elétrons secundários para o aço $316 \mathrm{~L}$. (a) $0,6 \mathrm{M} \mathrm{NaCl}$, (b) $0,45 \mathrm{M}$ $\mathrm{NaCl}+0,15 \mathrm{M} \mathrm{NaBr}$, (c) 0,3M NaCl+0,3M NaBr e (d) 0,6M NaBr. Lixa \#600. Aumento 50x.

Analogamente aos aços anteriores, na Figura 116 são observados pites com formato hemisférico (dissolução isotrópica). Cabe salientar, que os pites nucleados neste material apresentaram uma camada de metal remanescente na parte superior, a qual permite estabilizar as condições criadas durante o processo de corrosão, as quais irão impedir a repassivação do pite. 


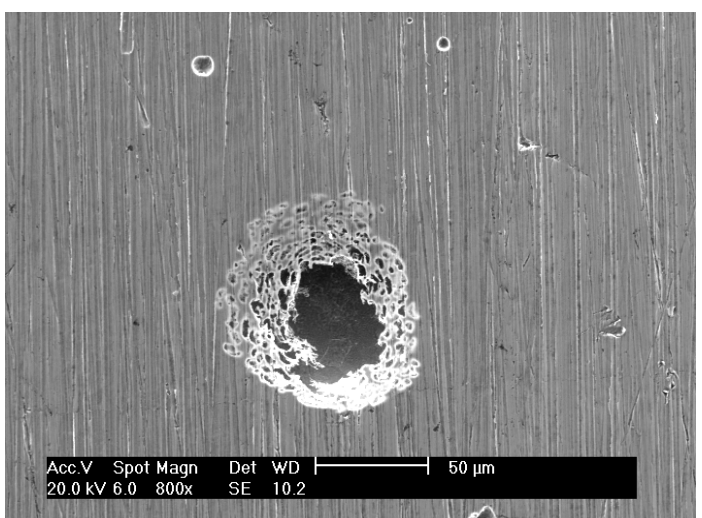

(a)

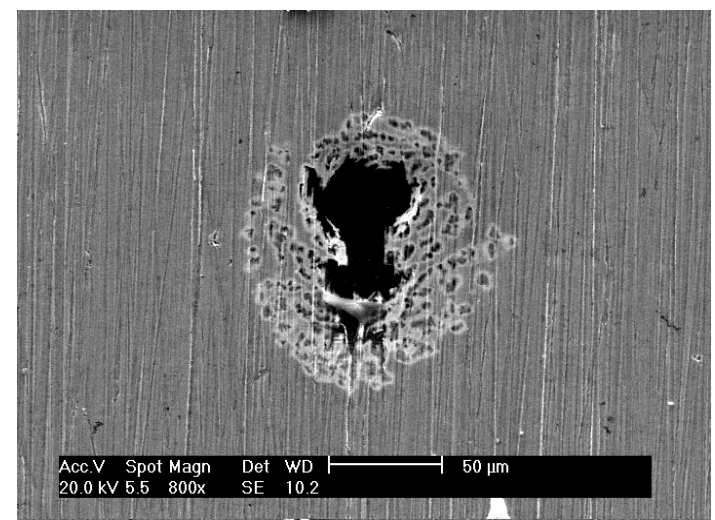

(c)

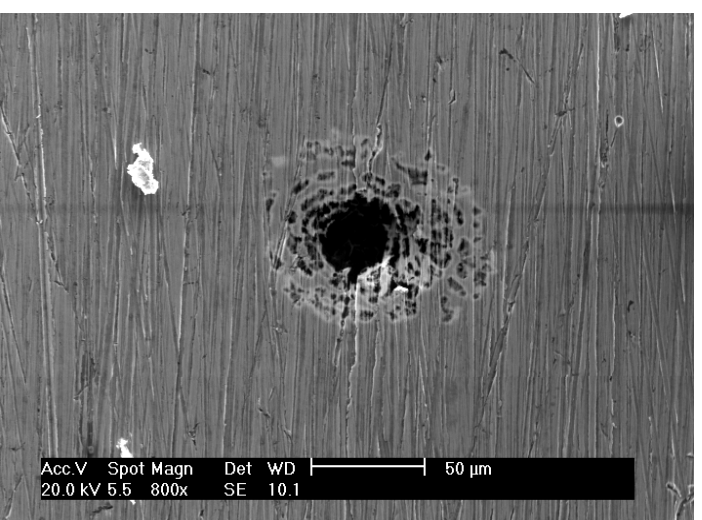

(b)

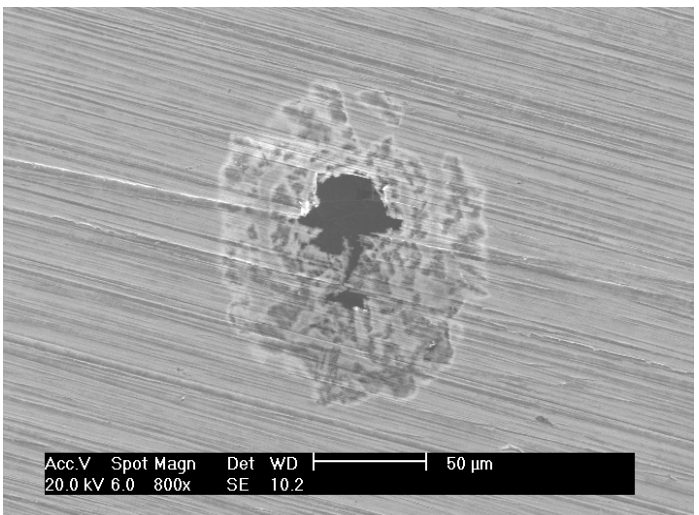

(d)

Figura 116 - Imagens de elétrons secundários dos pites nucleados na superfície do aço $316 \mathrm{~L}$ durante o ensaio de corrosão. (a) $0,6 \mathrm{M} \mathrm{NaCl}$, (b) $0,45 \mathrm{M} \mathrm{NaCl}+0,15 \mathrm{M} \mathrm{NaBr}$, (c) $0,3 \mathrm{M}$ $\mathrm{NaCl}+0,3 \mathrm{M} \mathrm{NaBr}$ e (d) 0,6M NaBr. Lixa \#600. Aumento 800x.

\subsubsection{AÇO INOXIDÁVEL 430}

A distribuição dos pites nucleados na superfície durante o ensaio de polarização é apresentada na Figura 117. É importante ressaltar que a menor densidade de pites ocorreu na presença de brometo $(0,6 \mathrm{M} \mathrm{NaBr})$. De fato, este fenômeno poderia estar relacionado ao efeito da composição química do aço, onde, o níquel estaria prejudicando a resistência à nucleação de pite. 


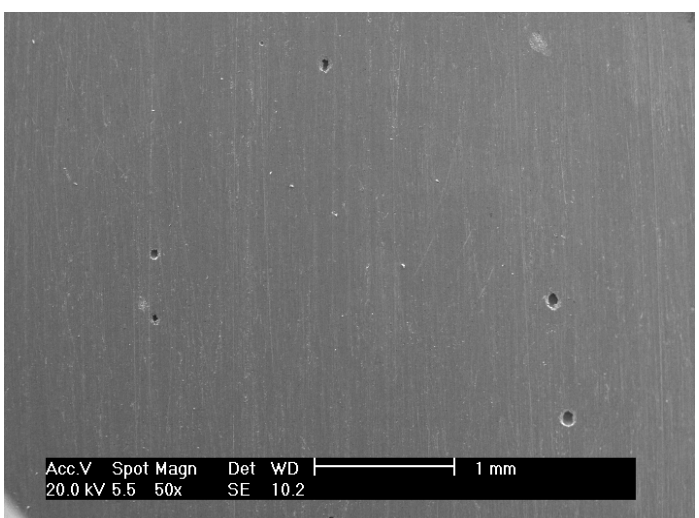

(a)

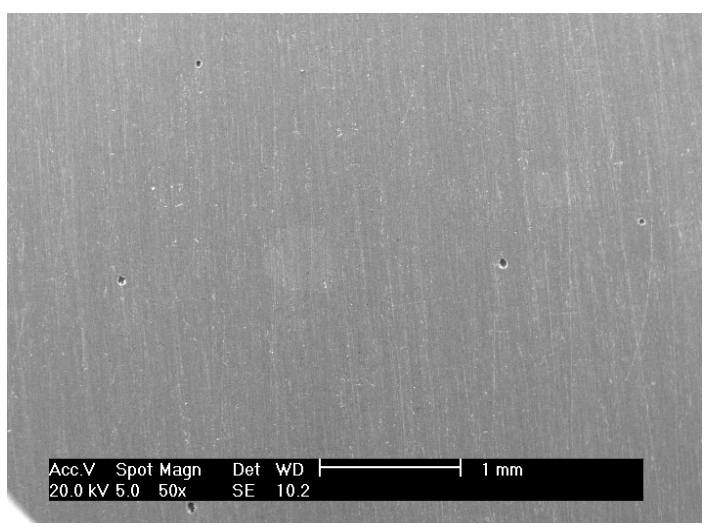

(c)

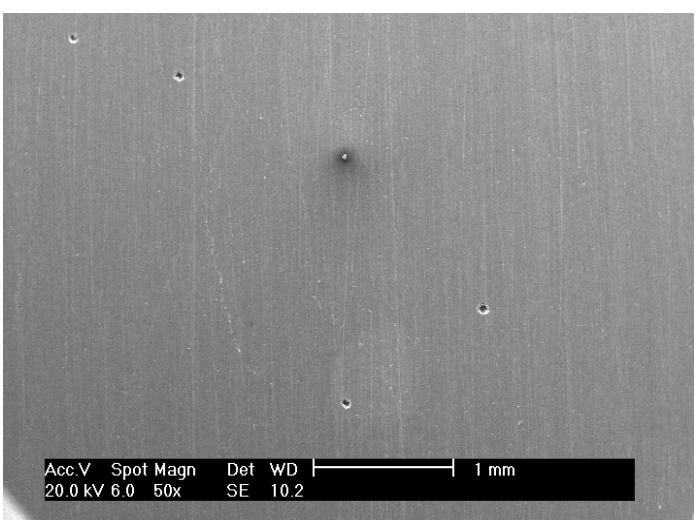

(b)

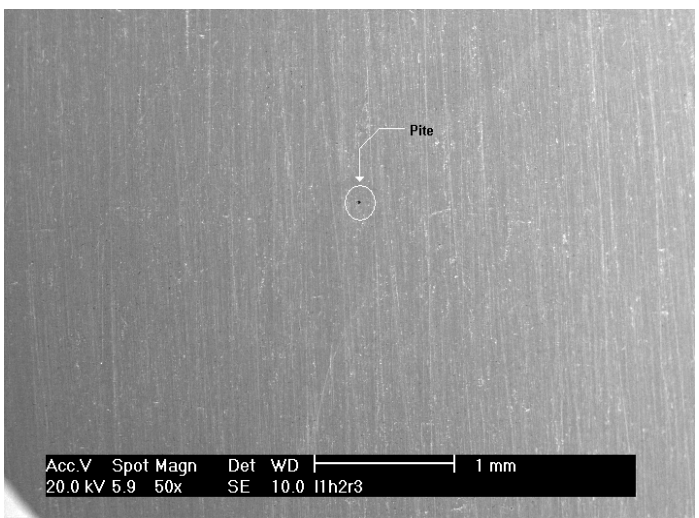

(d)

Figura 117 - Imagem de elétrons secundários para o aço 430 . (a) $0,6 \mathrm{M} \mathrm{NaCl}$, (b) $0,45 \mathrm{M}$ $\mathrm{NaCl}+0,15 \mathrm{M} \mathrm{NaBr}$, (c) 0,3M NaCl+0,3M NaBr e (d) 0,6M NaBr. Aumento 50x. Lixa \#600.

Na Figura 118 são observados pites com formato hemisférico (dissolução isotrópica). Da Figura 118 pode-se observar a ausência da camada de metal que recobre o pite na parte superior, a qual influencia a estabilização do crescimento do pite.

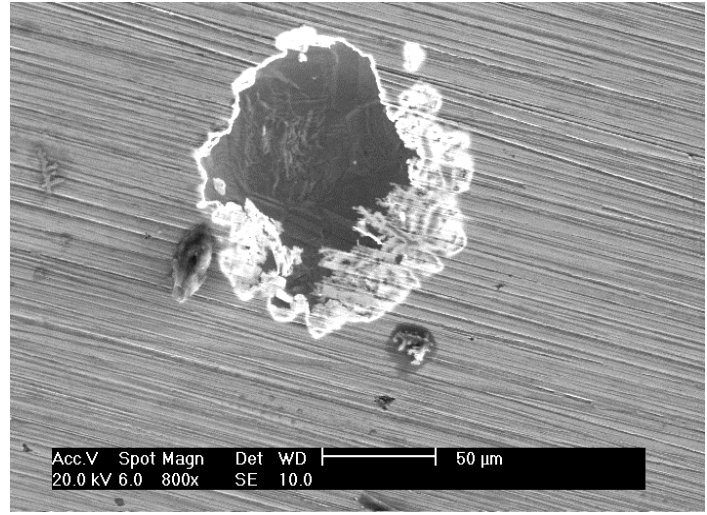

(a)

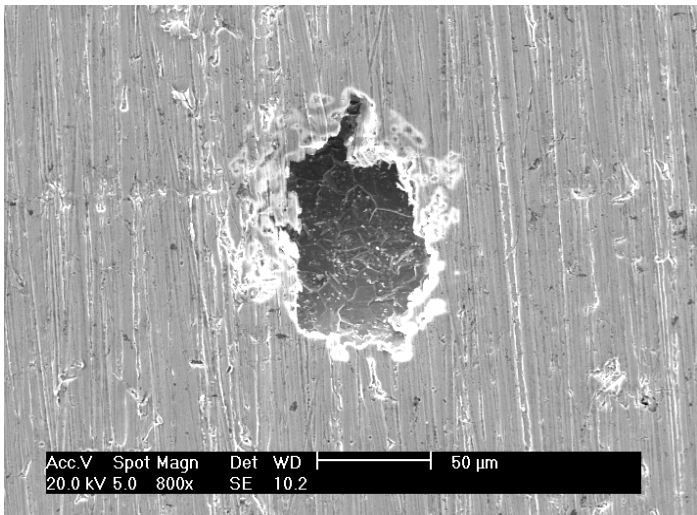

(b) 


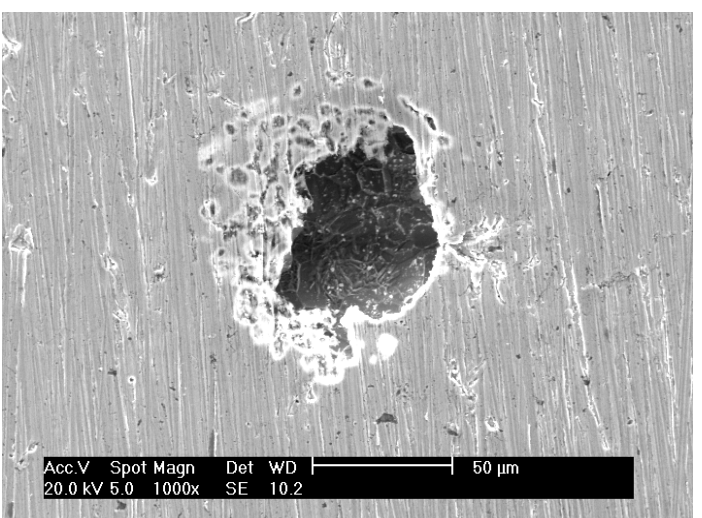

(c)

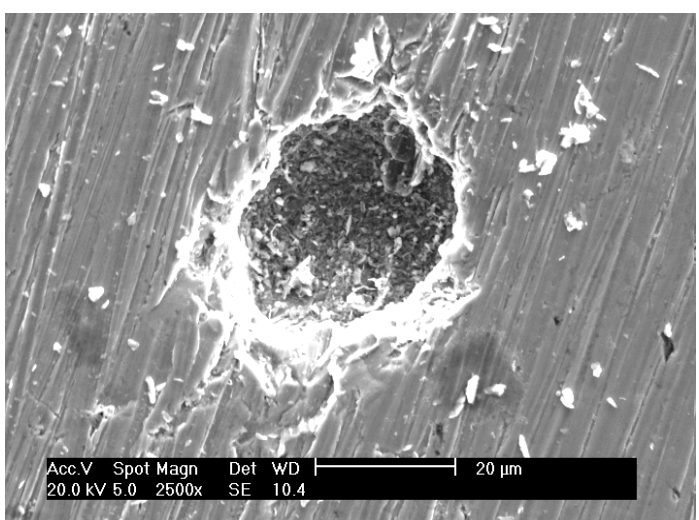

(d)

Figura 118 - Imagens de elétrons secundários dos pites nucleados na superfície do aço 430 durante o ensaio de corrosão. (a) $0,6 \mathrm{M} \mathrm{NaCl}$, (b) $0,45 \mathrm{M} \mathrm{NaCl}+0,15 \mathrm{M} \mathrm{NaBr}$, (c) $0,3 \mathrm{M}$ $\mathrm{NaCl}+0,3 \mathrm{M} \mathrm{NaBr}$ e (d) 0,6M NaBr. Lixa \#600. Aumento 800x para (a), (b), de 1000x para (c) e $2500 \times$ para $(d)$.

A Figura 119 mostra um pite com precipitados de carbonetos de cromo no seu interior, os quais apresentam formato globular. Estes tipos de precipitados foram encontrados na caracterização microestrutural realizada anteriormente neste material. O resultado da análise por EDS está apresentado na Figura 120 , onde é possível esclarecer a presença desse tipo de carbonetos.

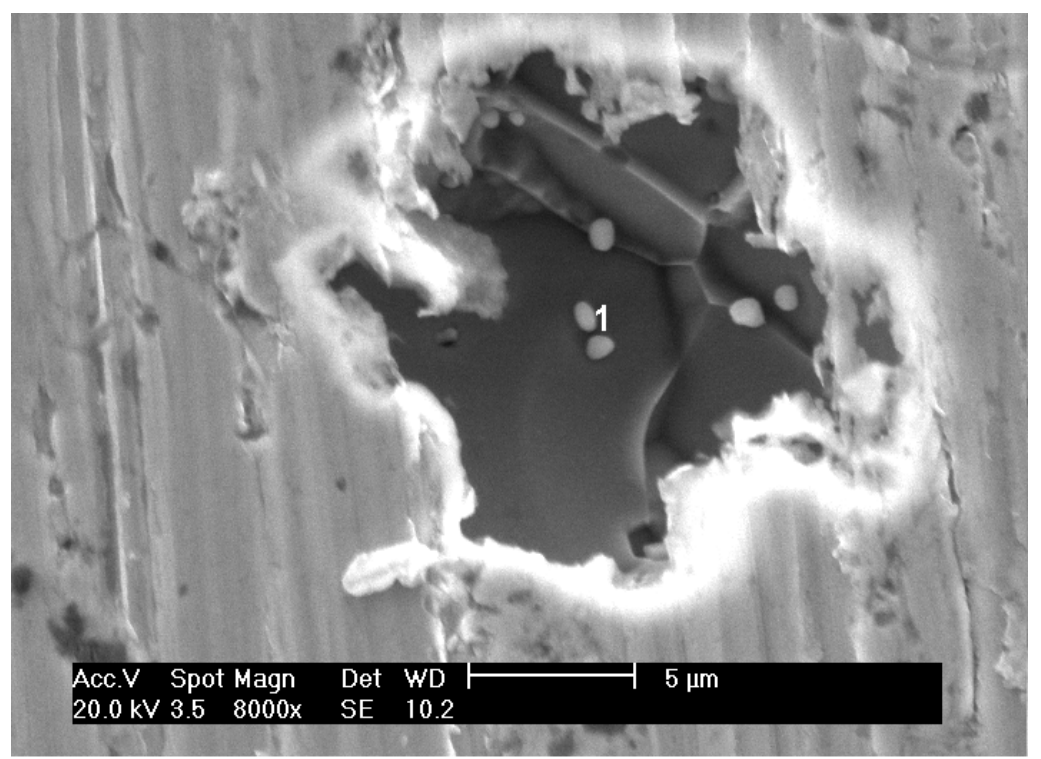

Figura 119 - Imagem de elétrons secundários. Nota-se a presença de carbonetos de cromo globulares no interior do pite. Aumento 8000x. 


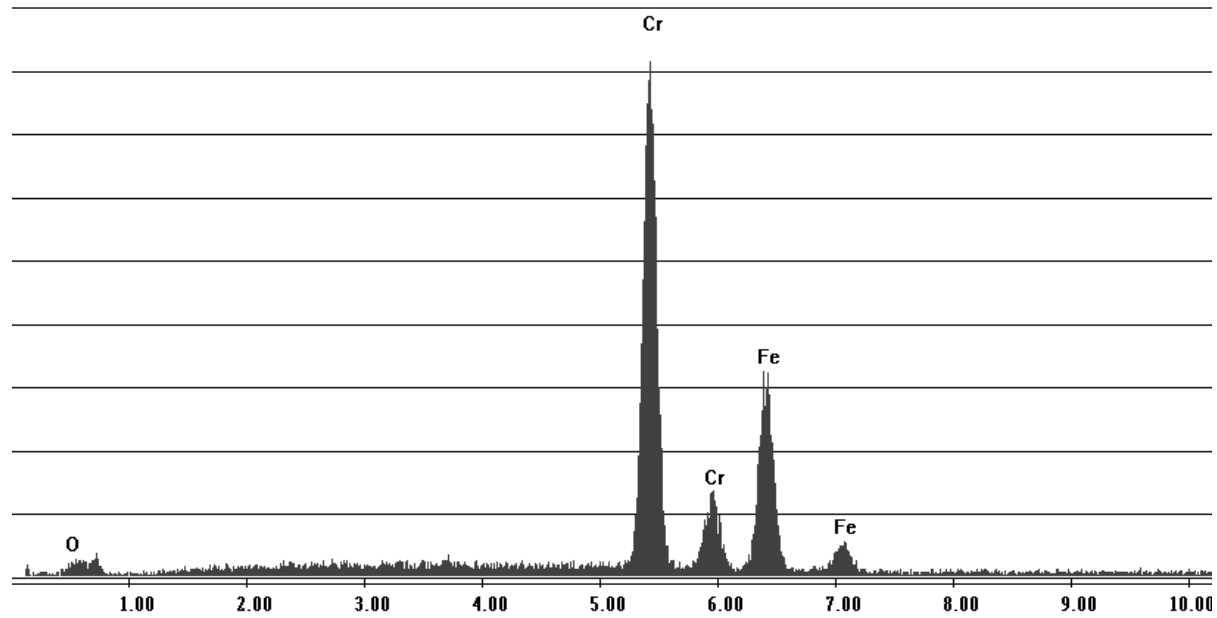

Figura 120 - Espectro da análise por EDS realizada no ponto 1 (resíduo com formato globular). Nota-se elevado teor de Cr.

\subsubsection{AÇO INOXIDÁVEL 444}

A Figura 121 mostra a distribuição dos pites nucleados sobre a superfície do aço. Cabe ressaltar, que o aço 444 apresentou alta densidade de pites no eletrólito de $0,45 \mathrm{M} \mathrm{NaCl}+0,15 \mathrm{M} \mathrm{NaBr}$.

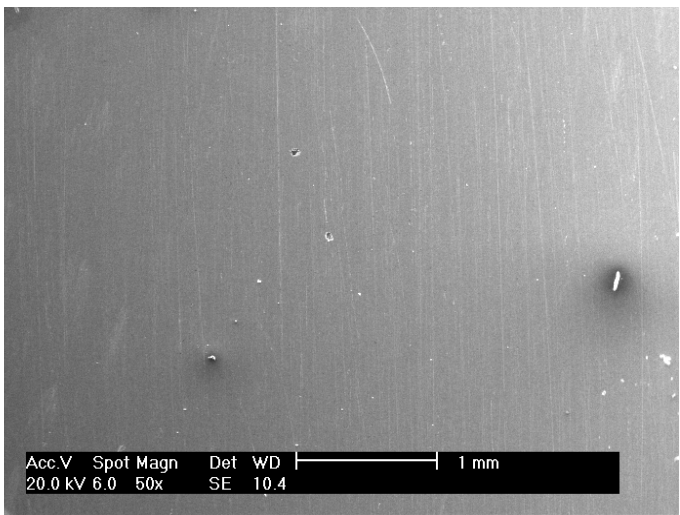

(a)

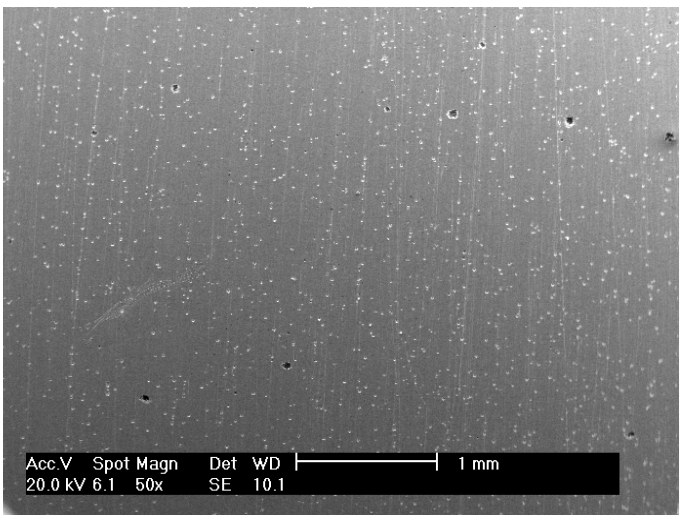

(b) 


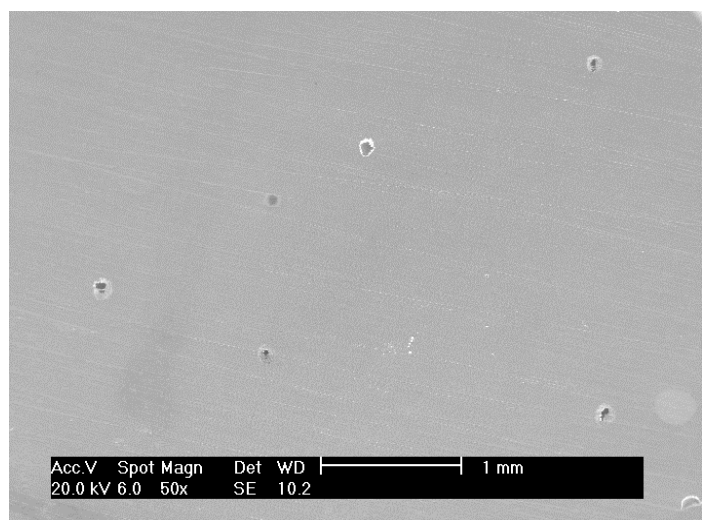

(c)

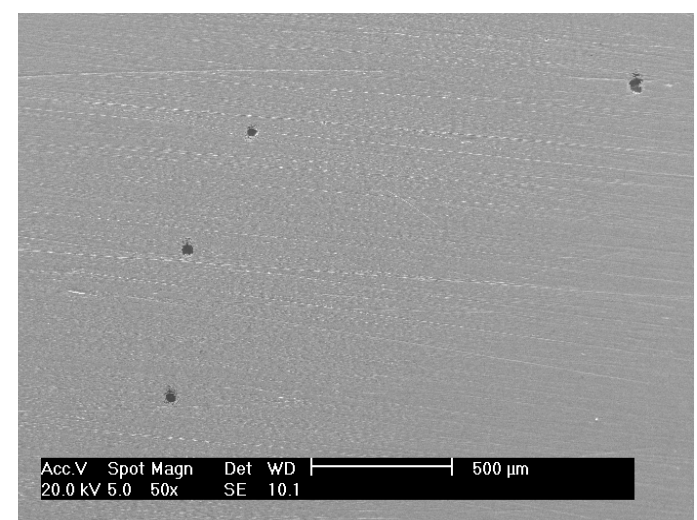

(d)

Figura 121 - Imagem de elétrons secundários para o aço 444. Distribuição dos pites na superfície do aço 444.(a) $0,6 \mathrm{M} \mathrm{NaCl}$, (b) $0,45 \mathrm{M} \mathrm{NaCl}+0,15 \mathrm{M} \mathrm{NaBr}$, (c) $0,3 \mathrm{M} \mathrm{NaCl}+0,3 \mathrm{M} \mathrm{NaBr}$ e (d) 0,6M NaBr. Lixa \#600. Aumento 50x.

O ensaio em $0,45 \mathrm{M} \mathrm{NaCl}+0,15 \mathrm{M} \mathrm{NaBr}$ apresentou um resultado, em termos de densidade de pites nucleados, muito diferenciado. Por tal motivo, o ensaio foi refeito, sendo obtido o mesmo resultado. Além disso, quando da observação em MEV, foram realizadas análises por EDS, sendo observado que todos os pontos brancos da Figura 121(b) eram constituídos por Ba e S.

Não é de se esperar que o aço 444 tenha tão grande quantidade de inclusões de sulfeto de bário (apesar de que este foi um dos aços que maior densidade de inclusões apresentou quando da caracterização microestrutural ver item 6.1). Por tal motivo, volta-se a considerar a hipótese de que o teor de Ba presente na composição química do aço, mais as contaminações presentes nos sais de $\mathrm{NaBr}$ e $\mathrm{NaCl}$, além de sulfatos presentes nestes sais, sejam responsáveis pela precipitação de compostos de Ba e $\mathrm{S}$, no interior dos pites formados. Lembra-se que a mistura de sais, pode alterar a atividade dos componentes e causar a precipitação de novos produtos em soluções menos concentradas.

Na Figura 122 são observados pites com formato hemisférico (dissolução isotrópica), sem resíduos de corrosão no seu interior e abertos na parte superior. Da mesma maneira que os aços anteriores, a camada de metal na parte superior do pite, ajuda à estabilização das condições criadas no interior do pite (mantendo o $\mathrm{pH}$ baixo) e permitindo desta forma, o seu crescimento continuo. 


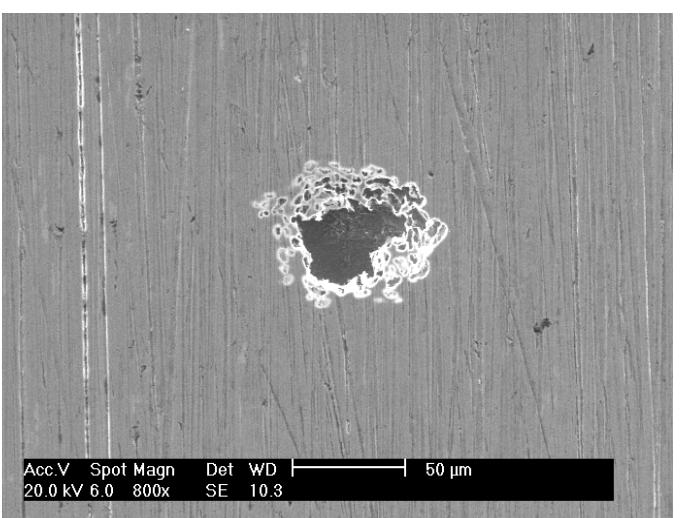

(a)

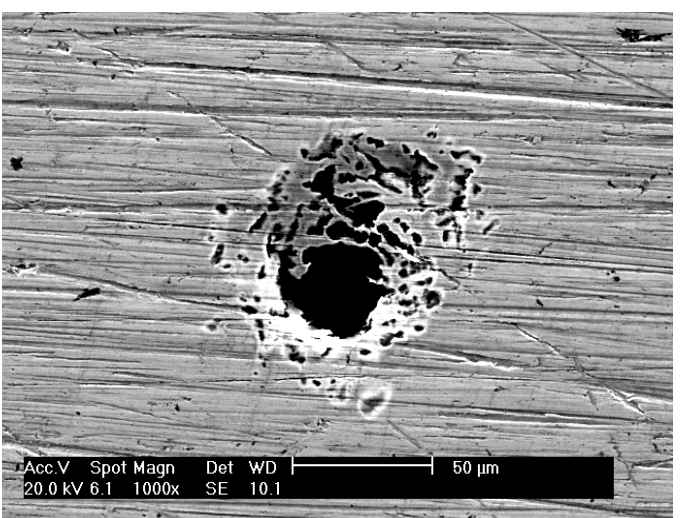

(c)

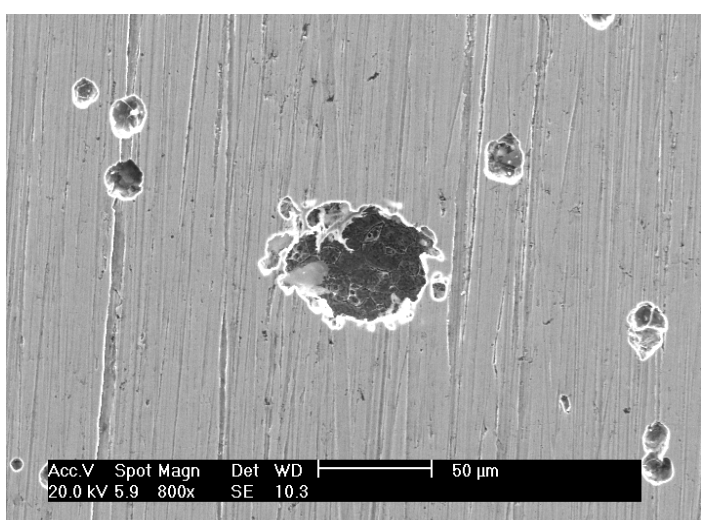

(b)

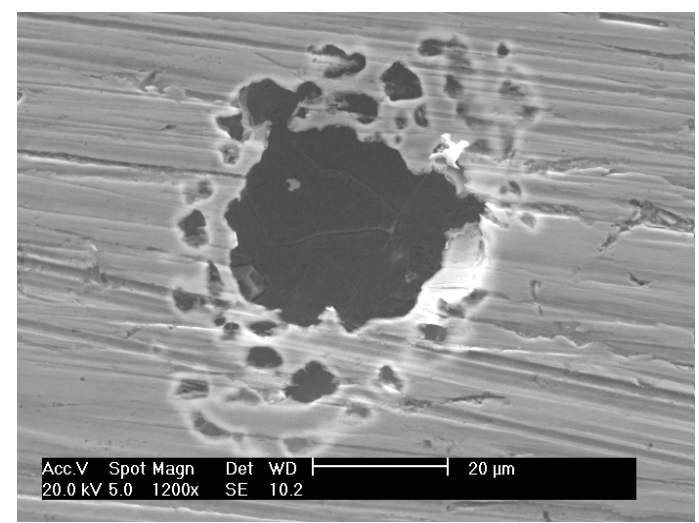

(d)

Figura 122 - Imagens de elétrons secundários dos pites nucleados na superfície do aço 444 durante o ensaio de corrosão. (a) $0,6 \mathrm{M} \mathrm{NaCl}$, (b) $0,45 \mathrm{M} \mathrm{NaCl}+0,15 \mathrm{M} \mathrm{NaBr}$, (c) $0,3 \mathrm{M} \mathrm{NaCl}+0,3 \mathrm{M}$ $\mathrm{NaBr}$ e (d) 0,6M NaBr. Lixa \#600. Aumento 800x para (a) e (b), de 1000x para (c) e 1200x para (d).

\subsection{COMPARAÇÃO DO POTENCIAL DE PITE DOS DIFERENTES AÇOS NOS DIFERENTES ELETRÓLITOS}

A Figura 123 apresenta o potencial de pite (Ep), para cada aço deste estudo, em função do teor de cloreto $(\mathrm{NaCl})$ para eletrólitos que contém $0,6 \mathrm{M}$ de íons $\left(\mathrm{Cl}^{-}+\mathrm{Br}^{-}\right)$. Na Figura 123 é possível comparar a resistência à corrosão por pite de cada aço em função da composição química do eletrólito, e também, pode-se comparar a resistência à corrosão por pite entre os diferentes tipos de aços inoxidáveis.

O desempenho encontrado para os aços em meio contendo brometo puro (Figura 123) sugere que a presença dos elementos $\mathrm{Ni}, \mathrm{Mn}, \mathrm{Mo}, \mathrm{Ti}$ e $\mathrm{Nb}$ nas composições químicas, possam explicar o comportamento obtido. A ordem 
decrescente do desempenho dos aços, em brometo puro, é a seguinte: 444 , 316L, 304, 298 e, por último, o aço 430.

$\mathrm{O}$ aço 430, não contém nenhum desses elementos, pois se trata de uma liga Fe-Cr. A ausência de Ni, Mn, Mo, Ti e Nb no aço 430 é o fator que o coloca como o material de menor resistência à corrosão por pite.

Desse modo, a combinação de Ni-Mn (aço 298 "Cr-Ni-Mn") já é eficaz no sentido de originar certa resistência à corrosão por pite, maior do que aquela do aço 430.

Por sua vez, a combinação Ni-Mo (316L) incrementa essa resistência à corrosão.

Já o aço 444, é um aço ferrítico e, portanto, não contém $\mathrm{Ni}$ nem $\mathrm{Mn}$, e, apresentou o melhor desempenho quanto à resistência à corrosão por pite em brometo puro. No entanto, o aço 444 contém Mo, Ti e Nb. Seria prematuro atribuir o ótimo desempenho do aço 444 apenas à adição de Mo. Sugere-se que a adição de Mo-Ti-Nb possa explicar esse desempenho, mas, é necessário mais trabalho de pesquisa para esclarecer o mecanismo de atuação.

Quando o eletrólito puro de $0,6 \mathrm{M} \mathrm{NaBr}$ é substituído pelo eletrólito de $0,3 \mathrm{M} \mathrm{NaCl}+0,3 \mathrm{M} \mathrm{NaBr}$ a sequência de resistência à corrosão por pite entre os diferentes aços se manteve. De modo geral, isso também acontece para o eletrólito de $0,45 \mathrm{M} \mathrm{NaCl}+0,15 \mathrm{M} \mathrm{NaBr}$, com um destaque para os aços $304 \mathrm{e}$ 316 L que apresentaram Ep muito próximos.

Por sua vez, em meio puro de cloreto, a resistência à corrosão por pite apresentou uma inversão entre os aços 444 e 316L. Isso corrobora o que já é conhecido na literatura especializada sobre o efeito benéfico do Mo em meio contendo cloreto. No presente caso, o aço $316 \mathrm{~L}$, além do Ni, contém maior teor de Mo do que o aço 444; o que talvez seja a justificativa de seu melhor desempenho.

Outro ponto que se pode destacar da Figura 123 é que o aço 430, que é praticamente uma liga $\mathrm{Fe}-\mathrm{Cr}$, é o material mais sensível às alterações de composição de eletrólito, notando-se que o aumento da concentração de cloreto diminui mais acentuadamente o Ep desse material. Os aços mais ligados não foram tão susceptíveis às alterações de composição química dos eletrólitos, mas percebe-se que também os aços 298 e 444 também tem seu Ep diminuído para o eletrólito puro de cloreto. 
No item de ensaios de polarização potenciodinâmica (6.2) foi discutida a capacidade de minimização de pites instáveis do íon brometo, isto é, uma vez nucleado o pite nesse eletrólito, seu crescimento ocorre continuamente. Esse comportamento foi explicado pela maior capacidade de acidificação do ácido bromídrico. Por outro lado, os resultados da Figura 123, mostram que, apesar desse efeito no crescimento do pite, o íon brometo é menos agressivo do que o íon cloreto na etapa de nucleação do pite, a qual envolve a adsorção dos íons agressivos e a ruptura das películas passivas. Convém lembrar que a adsorção depende de sítios ativos e também da composição química do substrato; isso, faz notar que os dois aços que tiveram o aumento do Ep para a solução pura de cloreto, são justamente os dois que contém maior teor de Ni: os aços 304 e $316 \mathrm{~L}$, ou seja, isso indica um efeito benéfico do $\mathrm{Ni}$ sobre a resistência à nucleação de pites. 


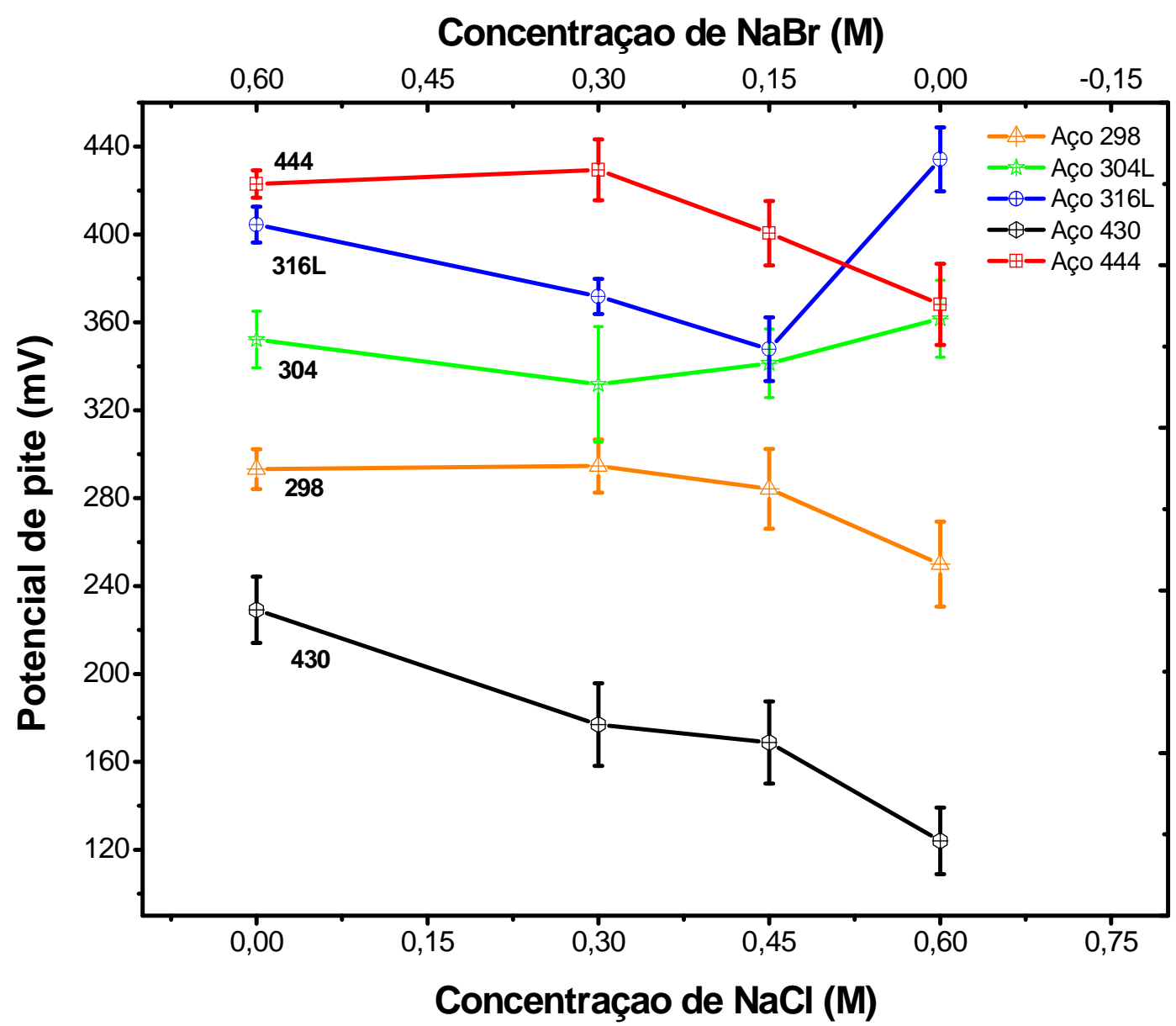

Figura 123 - Influência do teor dos íons agressivos de cloreto e brometo no potencial de pite dos aços (298, 304, 316L, 430 e 444). O eixo horizontal inferior é "Concentração de cloreto"; o eixo horizontal superior é "Concentração de brometo". O eixo vertical é: "Potencial de pite $(\mathrm{mV}, \mathrm{Ag} / \mathrm{AgCl})$ ". A concentração total de íons agressivos é de $0,6 \mathrm{M}$ em todos os casos. 


\section{CONCLUSÕES}

- Mediante a realização deste trabalho foi possível comparar tanto a resistência à corrosão para cada aço inoxidável em função da concentração de cloreto e brometo no eletrólito, quanto a resistência à corrosão entre os diferentes tipos de aços inoxidáveis.

- Observou-se a influência do tipo de íon agressivo na formação de pites instáveis. Este comportamento está relacionado ao fato de cada tipo de íon agressivo ter a capacidade de formar um ácido dentro do pite mais ou menos forte (grau de dissociação) durante o processo de corrosão. No presente estudo, a formação de ácido bromídrico no interior dos pites (que é um ácido mais forte do que o ácido clorídrico) é a proposta para explicar a ausência de pites instáveis em meio de brometo de sódio, comparativamente ao meio de cloreto de sódio.

- Mediante os estudos realizados para os sítios de nucleação de pite, foi encontrado que as inclusões têm um papel importante sobre a resistência à corrosão por pite, agindo como sítios de nucleação através de sua dissolução ou do ataque à interface matriz/inclusão.

- As inclusões de sulfeto de manganês puras encontradas nos aços inoxidáveis austeníticos não tiveram uma influencia significativa na formação de pites. Isso pode estar relacionado ao fato dessas inclusões apresentarem pequena profundidade, de modo que, após sua dissolução, não é possível a manutenção das condições favoráveis $(\mathrm{pH}$ baixo) para o crescimento contínuo do pite.

- A resistência à corrosão por pite do aço $316 \mathrm{~L}$ não foi influenciada significativamente pelos eletrólitos puros de cloreto e brometo, mas, a mistura desses íons provoca uma diminuição considerável do potencial de pite. 
- Os aços 444 e $316 \mathrm{~L}$ são os que apresentam maior quantidade de elementos de liga na sua composição química, e foram os que apresentaram os melhores desempenhos quando testados em eletrólitos contendo brometo e cloreto. Este comportamento coloca em evidência a influencia dos elementos de liga: $\mathrm{Mo}, \mathrm{Ti}, \mathrm{Nb}$ e $\mathrm{Ni}$ sobre resistência à corrosão por pite. Já o aço 430 (liga $\mathrm{Fe}-\mathrm{Cr}$ ) foi o aço que apresentou o pior desempenho, o que corrobora a importância dos elementos de liga para se obter melhores desempenhos à corrosão por pite.

- O aço 298 não apresentou um desempenho significante na resistência à corrosão por pite. Pode-se explicar este comportamento devido à substituição de uma parte de níquel por manganês, onde a combinação desses dois elementos não é suficiente para obter um aço com níveis altos de resistência à corrosão por pite. 


\section{SUGESTÕES DE TRABALHOS FUTUROS}

A presente pesquisa mostrou que a resistência à corrosão por pite em meio contendo cloreto, brometo e suas misturas, é fortemente influenciada pela composição química e pelas heterogeneidades presentes no material (inclusões). Portanto, sugere-se para um melhor esclarecimento, e talvez, para uma explicação mais precisa do fenômeno que ocorre referente ao comportamento dos aços inoxidáveis nos diferentes eletrólitos o seguinte:

- Estudar os sítios de nucleação de pites utilizando corpos-de-prova polidos até $1 \mu \mathrm{m}$. Deve ser realizada uma caracterização minuciosa da superfície antes e após o ensaio de polarização potenciodinâmica para poder determinar o papel das inclusões na nucleação de pites. Para poder encontrar a influência das inclusões é necessário realizar um mapeamento químico (EDS) para observar como está composta a inclusão, e onde ocorreu a nucleação do pite.

- Sugere-se um estudo experimental da adsorção dos íons agressivos cloreto e brometo em aços inoxidáveis com diferentes composições químicas, verificando a correlação das características de adsorção com a resistência à corrosão por pite. 


\section{REFERÊNCIAS BIBLIOGRÁFICAS}

[1] Szklarska-Smialowska Z.. Pitting Corrosion of Metals, Houston: National Association of Corrosion Engineers (NACE), 1986.

[2] Walter J. T.. Influence of molybdenum species on pitting corrosion of stainless steels. Tese (doutorado), Swiss Federal Institute of Technology Zurich, Zurich. 2004.

[3] Pardo, A; Merino, M.C; Coy, A.E; Viejo, F; Arrabal, R; Matykina, E. Pitting corrosion behaviour of austenitic stainless steels - combining effects of $\mathrm{Mn}$ and Mo additions. Corrosion Science, v. 50, p. 1796-1806, 2008.

[4] Lee, S.U; Ahn, J.C; Kim, D.H; Hong, S.C; Lee, K.S. Influence of chloride and bromide anions on localized corrosion of $15 \% \mathrm{Cr}$ ferritic stainless steel. Materials Science and Engineering, v. A434, p. 155-159, 2006.

[5] Lippold, J.C; Kotecki, D.J. Welding Metallurgy of Stainless Steel, New Jersey: WILEY-INTERSCIENCE, 2005.

[6] Schmuki, P; Lockwood, D.J; Ogata, Y.H; Seo, M; Isaacs, H.S. Pites and Pores III: Formation, Properties, and Significance for Advance Materials, New Jersey: The Electrochemical Society, Inc, 2004.

[7] Llewellyn , D.T; Hudd, R.C. Steel metalurgy and applications. Oxford : Butterworth Heinemann, Third Edition, 1998.

[8] Beranger, G; Lemaitre, C. La passivité des acierse inoxydables. Memoires Etudes Scientifiques de la Revue de Métallurgi, v. 85, n. 12, p. 675-688, 1988.

[9] Terada, M. Corrosão de aços inoxidaveis avançados em meios fisiológicos. Tese (doutorado). Universidade de São Paulo (USP), São Paulo, 2008. 
[10] Stainles Steel, Grade Description Summary. Disponivel em: www.225steel.com/catalog/stainless-steel.pdf, Acesso em: 26/03/2011.

[11] Cunha, E.E. Desenvolvimento Econômico Local da Zona Oeste do Rio de Janeiro e de seu Entorno. (Consultor), Junho 2009. Projeto FAPERJ no E26/110.644/2007.

[11] Cunha, E.E. Desenvolvimento Econômico Local da Zona Oeste do Rio de Janeiro e de seu Entorno. (Consultor), Junho 2009. Projeto FAPERJ no E26/110.644/2007.

[12] Duarte, S.B. Soldagem dos Aços Inoxidáveis. São Paulo : Acesita, 1997.

[13] Lo, K.H; Shek, C.H; e Lai, J.K.L. Recent developments in stainless steels, Materials Science and Engineering R, v. 65, p. 39-104, 2009.

[14] Ishigaki, T. Determination of the density of cementite, SCI p. 295-302, 1927, Vol. Repts. Tôhoku Imp. Univ.

[15] Castro, R. Tricot, R. Études de transformations isothermes dans les aciers inoxydablessemi-ferritiques á 17\% chrome, Memoires Scientifiques de la Revue de Metallurgie, v. 59, parte 1: p. 571-586, parte 2: p. 587-596, 1962.

[16] Shortsleeve, F. J. e Nicholson, M. E. Transformation in Ferritic Chromium Steel between 1100 at 1500 F, ASM Transaction, v. 43, p. 142-156.

[17] Giraldo, C.A.S. Resistência à corrosão intergranuar do aço inoxidável ferrítico UNS S43000: avaliação por método de reativação eletroquímica, efeito de tratamento isotermico e mecanismo de sensitização. Tese de Doutorado, São Paulo - Universidade de São Paulo (USP), p. 85, 2006.

[18] Zapffe, C.A. Stainless Steel. Cleveland, Ohio: The American Society for Metals, 1949. 
[19] Schweitzer, P. A. Fundamentals of Metallic Corrosion "Atmospheric and Media Corrosion of Metals". Florida, Boca Raton : CRC Press, Corrosion Engineering Handbook, Second Edition,2007.

[20]. Tschiptschin, A.P; Pinedo, C.E. Estrutura e Propiedades do Aço Inoxidável Austenítico AISI 316L Grau F138 Nitretado sob Plasma a Baixa Temperatura. disponivel em: www.nucleoinox.org.br/upfiles/.../inox08/pg_192-197.pdf.

[21] Sedriks, A. J, Corrosion of stainless steels, segunda edição, john wiley \& sons, New york, 1996.

[22] J. Charles, J.D. Mithieux, J. Krautschick, N. Suutala, J. Antonio Simón, B. Van Hecke, T. Pauly. A new european 200 series standard to substitute 304 austenitics? 2011. disponivel em :

www.arcelormittal.com/stainlesseurope/.../European_200_Sereies_EN_10p_28 7Ko_Helsinki2008.pdf , acesso 26/11/2010.

[23] International Stainless Steel Forum (ISSF), New 200-series" steels: An opportunity or a threat to the image of stainless steel?, Disponivel em: http://www.worldstainless.org/NR/rdonlyres/9BF7E850-7425-4E82-B687-

765F33EBF63C/4733/ISSFNew200seriessteelsAnopportunityorathreattothei.pdf acesso: 04/09/2011.

[24] Speidel, M.O. Nitrogen Containing Austenitic Stainless Steels, Mat-wiss.

u. Werkstoiftech, v. 37 n. 10, p. 875-880, 2006.

[25] Charles, J; Mithieux, J.D; Krautschick, J; Suutala, N; Simón J.A; Van Hecke, B; Pauly, T.; A new european 200 series standard to substitute 304 austenitics, disponivel em: http://www.arcelormittal.com/stainlesseurope/sites/default/files/fc kfiles/uploadfile/Documentation/Technical_publication/European_200_Sereies_ EN_10p_287Ko_Helsinki2008.pdf, acesso: 09/04/2011. 
[26] QUE, F. L. LA. The problem of localized Corrosion, International Coference on Localized Corrosion, Houston : NACE, p. 147-153, 1974.

[27] MANSFELD, F. Corrosion Mechanism. Los Angeles, California: Marcel Dekker, Inc, 1987.

[28] Ernani, A; Paesano, A.J; Colucci, C.C; Melo, M.A; Zampronio, M.A. Implementar as técnicas de polarização potenciodinâmica e permeação eletroquímica do hidrogênio no laboratório de difusão do DFI. In: XI Encontro Anual de Iniciação Científica, Universidade Estadual de Maringá, Maringá- PR, de 1 a 4/10/2002.

[29] Dexter, S.C. Forms of Corrosion - Localized Corrosion. In: ASM Metals Handbook, Metals Park, ASM International, v. 13. p. 226-262, 1987.

[30] Szummer, A; Janik-Czachor, M; Hofmann, S. Discontinuity of the passivating film at nonmetallic inclusions in stainless steels, Materials Chemistry and Physics, v. 34. p. 181, 1993.

[31] Sato, N. Anodic Breakdown of Passive Films on Metals. Journal of The Electrochemical Society, v. 129, p. 255-260, 1982.

[32] Chawla, S. L; Gupta, R. K. Materials selection for corrosion control. Materials Park, OH: ASM Internationa, p. 65, 1995.

[33] DAVIS, J. R. ASM speciality handbook: stainless steels. Materials Park, OH: ASM International, 1996.

[34] Gentil, V. Corrosão. Rio de Janeiro: Livros Técnicos e Científicos. Rio de Janeiro. p. 368. 2003.

[35] Kaneko, M; Isaacs, H.S. Effects of molybdenum on the pitting of ferriticand austenitic-stainless steels in bromide and chloride solutions. Corrosion Science. v. 44, p. 1825-1834. 2002. 
[36] Bond, A.P. Effects of Molybdenum on the Pitting Potentials of Ferritic Stainless Steels at Various Temperatures, Journal Electrochemical Society, v. 120, p. $603,1973$.

[37] Tan, M.W; Akiyama, E; Kawashima, A; Asami, K; Hashimoto, K. The effect of air exposure on the corrosion behavior of amorphous Fe-8Cr-Mo-13P-7C alloys in $1 \mathrm{M} \mathrm{HCl}$. Corrosion Science, v. 37, p. 1289-1301, 1995.

[38] Yaniv, A.E., Lumsden, J.B. e Staehle, R.W. The composition of passive films on ferritic stainless steels., Journal Electrochemical Society, v. 124. p. 490-496, 1977.

[39] Barnes, C.G; Aldag, A.W; Jerner, R.C. Surface concentration of molybdenum in types 316 and 304 stainless steel by Auger electron spectroscopy. Journal Electrochemical Society, v. 119, p. 684-686, 1972.

[40] Strehblow, H.H., Nucleation and Repassivation of Corrosion Pits for Pitting on Iron and Nickel. Materials and Corrosion. v.27, p.792, 1976.

[41] Monaco, B. Determinação da resistência à corrosão por pite dos aços inoxidáveis ferríticos uns $\mathbf{s} 43000$ e uns s44400 após diferentes acabamentos superficiais. Trabalho de Formatura-Escola Politécnica da Universidade de São Paulo.São Paulo, São Paulo. p. 61, 2008.

[42] Marcus, P. Corrosion Mechanism in theory and practice. New York: Marcel Dekker, 2002.

[43] Fontana, M.G; Greene, N.D. Corrosion Engineering. Mc Graw Hill-USA, p. 465 , p. 51-52. 1978.

[44] Sato, N. A Theory for Breakdown of Anodic Oxide Films on Metals. Ekctrcchimka Acta. v. 16, p. 1663-1692, 1971. 
[45] Poyet, P; Desestret, A. Contribution to the Study of Pitting Corrosion of 18Cr-10Ni Type Stainless Steels. Effect of Different Variables on the Process of Pit Formation. Mem. Sci. Rev. Metal. v. 72, p. 133-145, 1975.

[46] Suter, T; Webb, E.G; Boehni, H; Alkire, R.C. Chemistry and Electrochemistry of Stress Corrosion, $\mathbf{T}$ Cracking: A Symposium Honoring the Contributions of R. W. Staehle, ed. R. H. Jones, TMS, p. 301. 2001.

[47] Dundas, H.J; Bond, A.P. Effects of Delta Ferrite and Nitrogen Contents on the Resistance of Austenitic Stainless steels to Pitting Corrosion. NACE Corrosion/75, v. Preprinted N"159, 1975.

[48] Eklund, G. S. Initiation of Pitting at Sulfide Inclusions in Stainless Steel, Journal Electrochemical Society, v.121, p. 467-473, 1974.

[49] Standard rating chart for pits: ASTM Practice G-46-94. ASTM, 1999.

[50] KOLOTYRKIN, YA. M. Corrosion, v. 19, n. 8, p. 265t, 1963.

[51] www.euro-inox.org/pdf/map/AlloyingElements_EN.pdf. acesso: 10/03/2011.

[52] Button, T. Estudo comparativo da resistência em meio ácido e em meio contendo cloreto dos aços inoxidáveis UNS 44400, UNS 30403 e UNS 31603, obtidos por laminação a quente, Trabalho de mestrado, Universidade de São Pulo (USP), São Paulo, 2008.

[53] Horvath, J; Uhlig, H.H. Critical Potentials for Pitting Corrosion of Ni, Cr-Ni, $\mathrm{Cr}-\mathrm{Fe}$, and Related Stainless Steels. Journal Electrochemical Society, p. 791-795, v. 115. Issue 8, 1968.

[54] Wegrelius, L; Olefjord, I. Passivation of Metals and semicunductors. Mat. Sci, v. 185. p. 347, 1995. 
[55] Ogwu, A; Davies, T.J. Improving the sensitisation resistance of ferritic stainless steel. n. 3, Scripta Materialia, v. 37, p. 259-263, 1997.

[56] Lee, J.B; Smith, J.F; Geiger, A.L; Kah, D.H. An analytical electron microscope examination of sensitized AISI 430 stainless steel. n. 2, Corrosion, v. 41, p. $76-80,1985$.

[57] Osozawa, K; Okato, N; Fukase, Y; Yokota, K Boshoku-Gijyutsu. Effects of Alloying Elements on the Pitting Corrosion of Stainless Steels. Corrosion Engeneering, v. 1, p. 24, 1975.

[58] Baba, H; Kodama, T; Katada, Y. Role of nitrogen on the corrosion behavior of austenitic stainless steels. Corrosion Science, v. 44, p. 2393-2407, 2002.

[59] Palit, G.C., Kain, V. e Gadiyar, H.S. Corrosion, v. 49, p. 977, 1993.

[60] Tobler, W.J. e Virtanen, S. Effect of Mo species on metastable pitting of Fe18Cr alloys - a current transient analysis, corrosion Science, v. 48. p. 1585-1607, 2006.

[61] Yang, W; Ni, R; Hua, H; Pourbaix, A. The behaviour of chromium and molybdenum in the propagation process of localized corrosion of steels, Corrosion Science, v. 24 p. 691-707, 1984.

[62] Murillo y Martin, M. L; Alonso-Falleiros, N. Efeito da substituição do íon cloreto por brometo nos eletrólitos usados na determinação do potencial de pite do aço UNS S31254., In: 59 ABM Annual International Congress, 22 de julio 2004.

[63] Wranglén, G. Pitting and sulphide inclusions in steel. Corrosion Science, v. 14, p. 331-349, 1974.

[64] http://es.wikipedia.org/wiki/\%C3\%81 cido_bromh\%C3\%ADdrico. acesso: de 19/05/2011. 
[65] Baker, M.A; Castle, J.E. The initiation of pitting corrosion of stainless steels at oxide inclusions, Corrosion Science, v. 33, No. 8, p. 1295-1312, 1992.

[66] Yun Soo Lim, A; Joung Soo, K; Se Jin, A; Hyuk Sang, K; Yasuyuki, K. The infuences of microstructure and nitrogen alloying on pitting corrosion of type 316L and 20 wt.\% Mn-substituted type 316L stainless steels, Corrosion Science, v. 43, p. 53-68, 2001.

[67] Tronstad, L; Sejsted, I. Journal Iron Steel Institue, v. 127. p. 425, 1933.

[68] Franckel, G.S; Stockert, L; Hunkeler, F; Boehni, H. Corrosion, v. 43, p. 429, 1987.

[69] Sridhar, N; Dunn, D.D. In Situ Study of Salt Film Stability in Simulated Pits of Nickel by Raman and Electrochemical Impedance Spectroscopies, Journal Electrochemical Society, v. 144. p. 4243, 1997.

[70] Hong, T., Walter, G. W; Nagumo, M. The observation of the early stages of pitting on passivated type 304 stainless steel in a $0.5 \mathrm{M} \mathrm{NaCl}$ solution at low potentials in the passive region by using the $\mathrm{AC}$ impedance method, Corrosion Science, v. 38, p. 1525-1533, 1996. 